\title{
Nutrition tactics to improve post-exercise recovery
}

Citation for published version (APA):

Trommelen, J. (2019). Nutrition tactics to improve post-exercise recovery. [Doctoral Thesis, Maastricht University]. Gildeprint Drukkerijen. https://doi.org/10.26481/dis.20191003jt

Document status and date:

Published: 01/01/2019

DOI:

10.26481/dis.20191003jt

Document Version:

Publisher's PDF, also known as Version of record

\section{Please check the document version of this publication:}

- A submitted manuscript is the version of the article upon submission and before peer-review. There can be important differences between the submitted version and the official published version of record.

People interested in the research are advised to contact the author for the final version of the publication, or visit the DOI to the publisher's website.

- The final author version and the galley proof are versions of the publication after peer review.

- The final published version features the final layout of the paper including the volume, issue and page numbers.

Link to publication

\footnotetext{
General rights rights.

- You may freely distribute the URL identifying the publication in the public portal. please follow below link for the End User Agreement:

www.umlib.nl/taverne-license

Take down policy

If you believe that this document breaches copyright please contact us at:

repository@maastrichtuniversity.nl

providing details and we will investigate your claim.
}

Copyright and moral rights for the publications made accessible in the public portal are retained by the authors and/or other copyright owners and it is a condition of accessing publications that users recognise and abide by the legal requirements associated with these

- Users may download and print one copy of any publication from the public portal for the purpose of private study or research.

- You may not further distribute the material or use it for any profit-making activity or commercial gain

If the publication is distributed under the terms of Article $25 \mathrm{fa}$ of the Dutch Copyright Act, indicated by the "Taverne" license above, 
Nutrition tactics to improve post-exercise recovery 

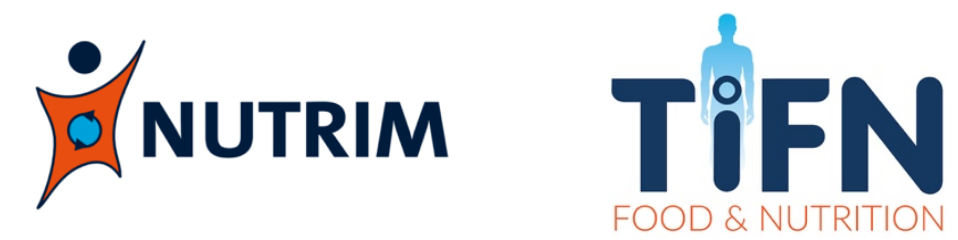

K E N N I S C E N T R U M

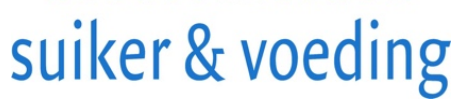

The studies presented in this thesis were performed within the NUTRIM, School of Nutrition and Translational Research in Metabolism at Maastricht University.

Studies presented in this thesis were partly performed within the framework of TI Food and Nutrition, and partly funded by a grant from the Kenniscentrum Suiker en Voeding.

Cover design: Denise Stienen

Lay out: Jorn Trommelen

Printed by: Gildeprint

ISBN: 978-94-6323-825-0

(C) Copyright Jorn Trommelen, Maastricht, 2019

All rights reserved. No part of this thesis may be reproduced, distributed, or transmitted in any form or by any means, including photocopying, recording, or other electronic or mechanical methods, without the prior written permission of the author or publisher, except in the case of brief quotations embodied in critical reviews and certain other noncommercial uses permitted by copyright law. 


\title{
Nutrition tactics to improve post-exercise recovery
}

\author{
DISSERTATION \\ To obtain the degree of Doctor at Maastricht University, \\ on the authority of the Rector Magnificus, Prof. dr. Rianne M. Letschert \\ in accordance with the decision of the Board of Deans, \\ to be defended in public on Thursday 3 October 2019, at 16:00 hours \\ by Jorn Trommelen
}

Born February 08, 1987, Goirle 


\section{Promotor}

Prof. dr. L.J.C. van Loon

\section{Co-promotor}

Dr. L.B. Verdijk

\section{Assessment committee}

Prof. dr. E.E Blaak (voorzitter)

Emeritus Prof. dr. W.H.M Saris

Emeritus Prof. dr. M.A. van Baak

Prof. dr. ir. C.P.G.M de Groot (Wageningen University)

Prof. dr. S.M. Phillips (McMaster University) 


\section{Table of Contents}

Chapter 1

Chapter 2

Chapter 3

Chapter 4

Chapter 5

Chapter 6

Chapter 7

Chapter 8

Summary

Samenvatting

Valorization

Dankwoord

Curriculum Vitae

Financial Support
General introduction

Fructose and sucrose intake increase carbohydrate oxidation during exercise

A sucrose mouth rinse does not improve $1 \mathrm{~h}$ cycle time trial performance when performed in the fasted or fed state muscle glycogen repletion

Dietary protein intake and distribution patterns of well-trained 73 Dutch athletes

Resistance exercise augments postprandial overnight muscle 89 protein synthesis rates

Pre-sleep dietary protein-derived amino acids are incorporated in myofibrillar protein during post-exercise overnight recovery

General discussion 



\section{Chapter 1}

General introduction 


\section{INTRODUCTION}

\section{Substrate metabolism}

Carbohydrate $(\mathrm{CHO})$ and fat are the two main fuel sources oxidized by skeletal muscle tissue during prolonged endurance-type exercise. The relative contribution of these fuel sources largely depends on the exercise intensity, exercise duration, and the training status of the athlete, with a greater contribution from carbohydrate as exercise intensity is increased [1-3] (Figure 1.1). Carbohydrate is stored in the body mainly as liver and muscle glycogen ( 100 $\mathrm{g}$ and $\sim 350-700 \mathrm{~g}$, respectively). These endogenous $\mathrm{CHO}$ stores are relatively small, representing less than $5 \%$ of the total energy storage [4]. However, muscle glycogen contributes more than $50 \%$ of total energy requirements during prolonged moderate- to high-intensity exercise [1,3]. Therefore, endogenous $\mathrm{CHO}$ availability may become a limiting factor for endurance performance and capacity in the absence of exogenous carbohydrate intake $[5,6]$. Consequently, the impact of exogenous $\mathrm{CHO}$ provision on endurance-type exercise performance and capacity has been a central topic in sports nutrition research [7].

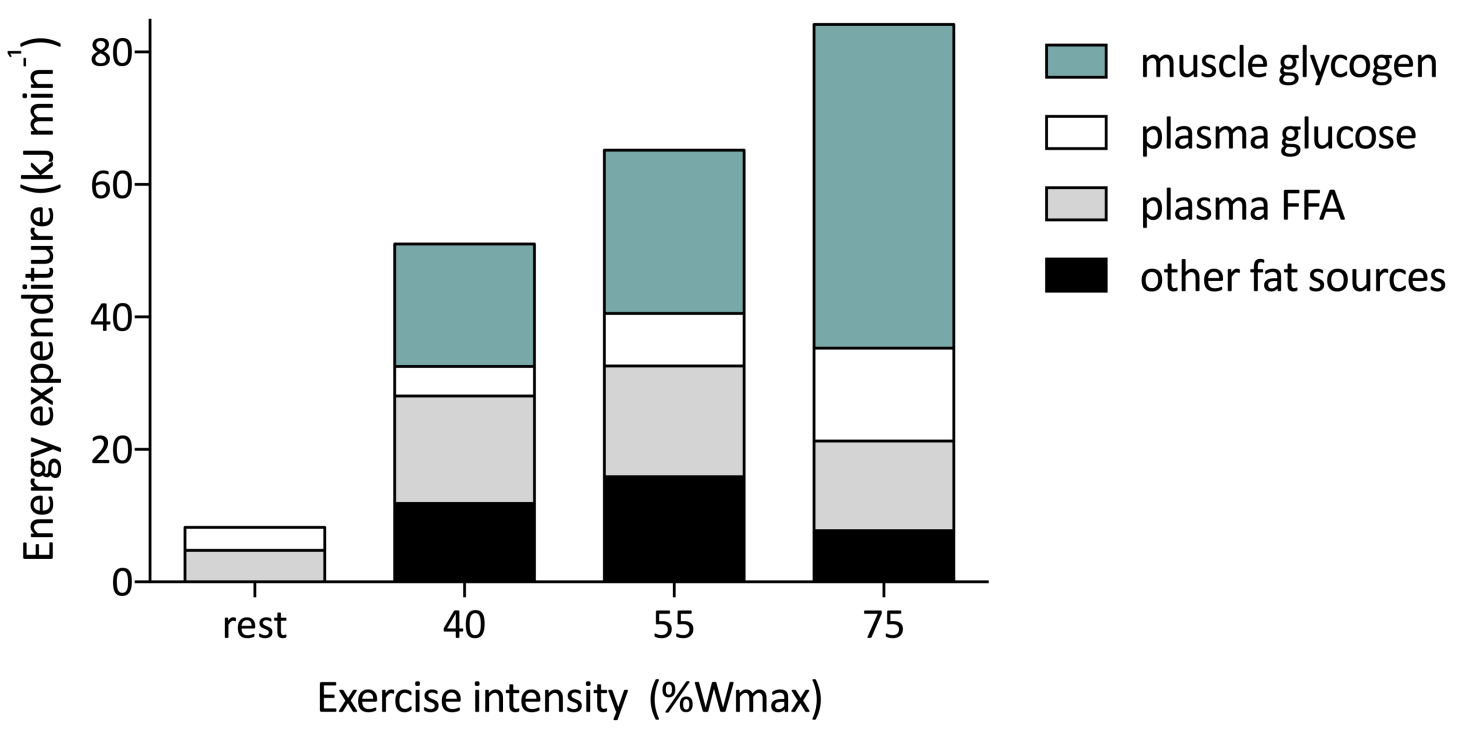

Figure 1.1 Energy expenditure and fuel selection as a function of exercise intensity. Illustration adapted from van Loon et al., J Physiol., 2001 [3].

\section{Nutritional support during exercise}

It has been well-established that carbohydrate ingestion during prolonged moderate- to high-intensity exercise can increase exercise performance and capacity [7-11]. Peak exogenous carbohydrate oxidation rates typically reach $\sim 1 \mathrm{~g} \cdot \mathrm{min}^{-1}$ during exercise when ample glucose or glucose polymers are ingested $[12,13]$. Fructose co-ingestion has been shown to further increase exogenous carbohydrate oxidation rates to 1.3-1.8 $\mathrm{g} \cdot \mathrm{min}^{-1}[14,15]$. While the impact of $\mathrm{CHO}$ supplementation on exercise performance increases with longer exercise durations [6], $\mathrm{CHO}$ ingestion has also been shown to improve performance during high-intensity exercise of a relative short duration ( $\leq 60 \mathrm{~min}$ ) [16-18]. As endogenous $\mathrm{CHO}$ stores should not be a limiting factor for optimal performance during exercise of such a short duration, this suggests that the ergogenic effects of $\mathrm{CHO}$ supplementation may not be limited to its role as a substrate source. 


\section{Nutritional support during post-exercise recovery}

In addition to direct ergogenic effects, nutritional support is also essential during the post-exercise recovery period to enhance exercise recovery and augment training adaptations. After cessation of endurance-type exercise, muscle glycogen is typically restored to pre-exercise levels within $24 \mathrm{~h}$ if sufficient amounts of $\mathrm{CHO}$ are ingested [19]. However, for athletes involved in multiple training sessions or competitions on the same day or successive days, (more) rapid repletion of muscle glycogen stores is required to prevent a decline in exercise performance. Therefore, much research has focused on nutritional strategies to optimize muscle glycogen repletion in the early post-exercise period. Postexercise muscle glycogen repletion is largely determined by exogenous carbohydrates provided [2025]. Protein co-ingestion has been shown to further accelerate muscle glycogen repletion rates, but only when suboptimal amounts of carbohydrates are ingested [24,25] (Figure 1.2). However, postexercise protein ingestion is warranted to stimulate muscle protein synthesis rates and thereby improve muscle recovery and augment training adaptations $[26,27]$. The majority of research has focused on the amount and type of protein to optimize muscle protein synthesis rates in the early post-exercise period [28-32]. As the adaptive response to a single bout of resistance exercise extends well beyond the first couple of hours of post-exercise recovery [33], recent studies have begun to investigate the impact of the timing and distribution of protein ingestion during more prolonged recovery periods $[34,35]$. As overnight sleep is typically the longest post-absorptive period during the day, protein ingestion prior to sleep has recently been suggested as a means to augment post-exercise overnight muscle protein synthesis rates $[35,36]$.

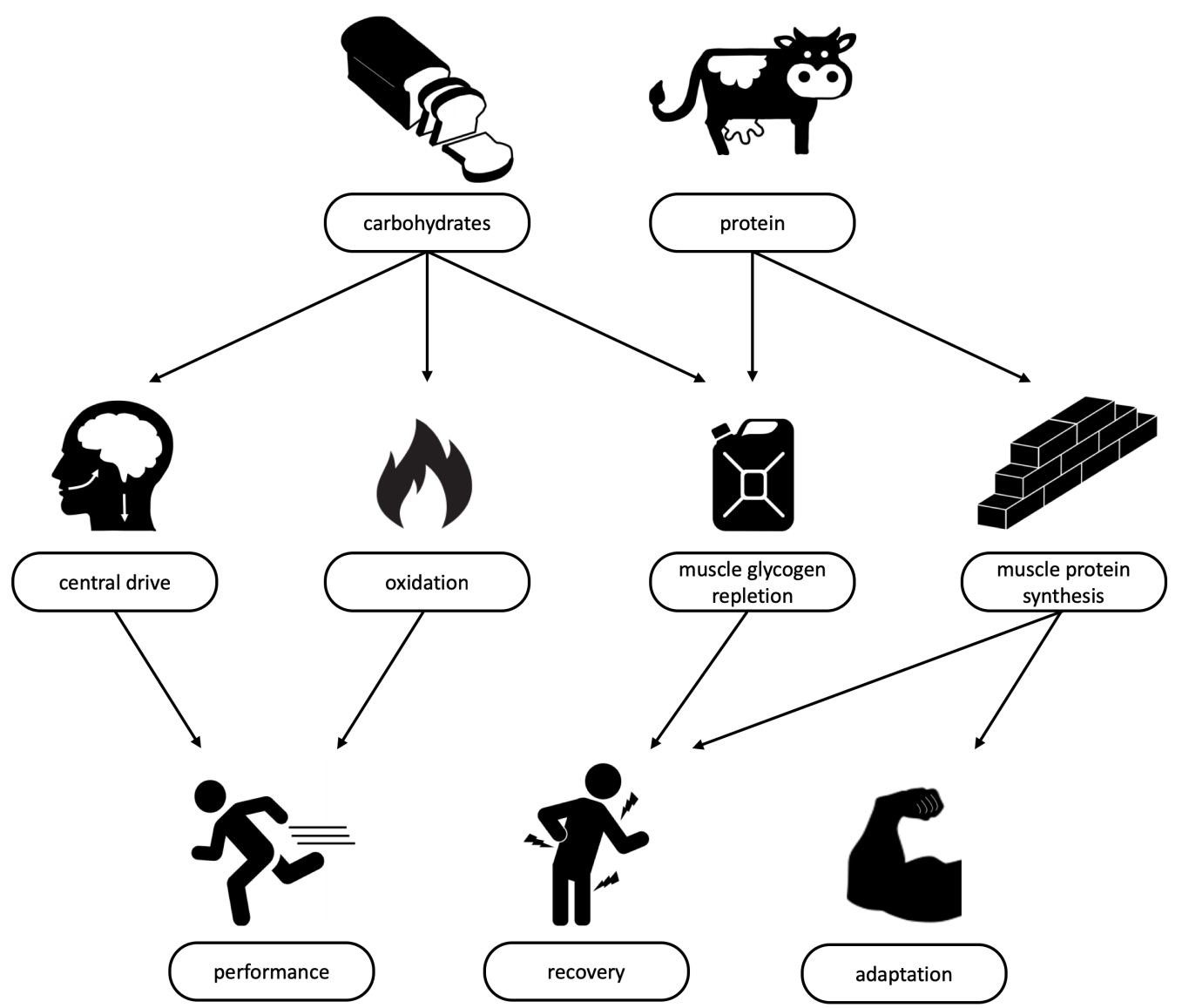

Figure 1.2 Proposed mechanisms by which carbohydrate and protein ingestion increase exercise performance, exercise recovery, and training adaptation. 


\section{Carbohydrates during exercise as an ergogenic aid}

The ergogenic effects of carbohydrate feeding during prolonged moderate- to high-intensity exercise has been well established [7]. Various factors have been suggested to contribute to the ergogenic effect of carbohydrate feeding, including the sparing of endogenous $\mathrm{CHO}$ stores, and the maintenance of plasma glucose levels.

\section{Carbohydrates during exercise to spare endogenous glycogen stores}

The importance of muscle glycogen as a substrate source in supporting exercise capacity is illustrated in McArdle's disease. Individuals with McArdle's disease are not able to utilize muscle glycogen as a substrate [37], and consequently have a very low exercise tolerance [38]. In healthy individuals, fatigue during prolonged endurance-type exercise is associated with the depletion of endogenous carbohydrate stores $[39,40]$. The provision of exogenous carbohydrate during exercise may attenuate the decline of endogenous carbohydrate stores. For example, early work by Bergstrom and Hultman demonstrated that an intravenous glucose infusion reduced muscle glycogen breakdown by $\sim 20 \%$ during 60 min of cycling [5]. While many subsequent studies have observed a lower rate of muscle glycogen utilization when carbohydrate was ingested during prolonged exercise [9,41-46], others have failed to confirm these findings [47-51]. For example, Coyle et al. observed an increase in time to fatigue when subjects ingested carbohydrate during exercise compared to a placebo, despite no differences in muscle glycogen utilization between the treatments [47]. While there is no clear explanation for the apparent discrepancy between studies, the impact of carbohydrate supplementation on muscle glycogen depletion may be time- and fibre-type-dependent and therefore not always detectable in mixed-muscle biopsies or by magnetic resonance spectroscopy $[43,46,52]$. Carbohydrate ingestion during prolonged exercise may not only spare muscle glycogen, but also preserve liver glycogen stores. Post-exercise liver glycogen repletion is associated with subsequent endurance capacity, and this association may be even stronger than for muscle glycogen repletion [53]. During exercise in a fasted state, plasma glucose that is taken up by muscle is continuously replaced by gluconeogenesis and glycogen degradation, mainly derived from the liver [54]. Liver glycogen is depleted by $\sim 50 \%$ within 90 min of exercise at $\sim 70 \% \mathrm{VO}_{2 \text { peak }}[51,53,55]$. The ingestion of carbohydrate during prolonged endurance-type exercise (180 min at 50\% $\mathrm{W}_{\text {max }}$ ) can completely preserve liver glycogen concentration [51]. Therefore, carbohydrate supplementation during exercise may be related to the sparing of both skeletal muscle and liver glycogen.

\section{Carbohydrates during exercise to maintain euglycemia}

Early work suggests that carbohydrate provision during prolonged endurance-type exercise improves endurance capacity and performance by maintaining plasma glucose concentrations and thereby allowing high carbohydrate oxidation rates. Coyle et al. demonstrated that carbohydrate ingestion during prolonged exercise to exhaustion $\left(71 \% \mathrm{VO}_{2 \text { peak }}\right)$ maintained plasma glucose concentrations and increased exercise capacity [47]. In a subsequent study, cyclists exercised at $70 \% \mathrm{VO}_{2 \text { peak }}$ until exhaustion, which resulted in lowered plasma glucose concentrations [56]. Following exhaustion, the cyclists rested for 20 min after which they performed a subsequent exercise bout to exhaustion after receiving supplemental carbohydrates, a glucose infusion, or a placebo. While plasma glucose concentrations initially increased in both the glucose ingestion and infusion treatments, only the infusion treatment was able to maintain euglycemia. In line, while both the glucose ingestion and infusion treatment increased the time to fatigue compared to the placebo treatment, the time to fatigue 
was significantly longer during the glucose infusion treatment compared to the glucose ingestion treatment. Therefore, the authors concluded that the decline in plasma glucose levels and the consequent fall in carbohydrate oxidation contributed to the inability to continue exercise [56]. However, the impact of hypoglycemia or its prevention does not always consistently improve endurance capacity $[57,58]$. Felig et al. observed hypoglycemia in approximately one third of subjects cycling to exhaustion on $60-65 \% \mathrm{VO}_{2 \max }$ in a fasted state [58]. However, subjects were able to continue to exercise for 15 to 70 minutes despite being hypoglycemic and their time to exhaustion was not significantly different from euglycemic subjects. Glucose ingestion at rates of $40 \mathrm{or} 80 \mathrm{~g} \cdot \mathrm{h}^{-1}$ prevented the hypoglycemia, but did not significantly increase time to fatigue [58].

As such, the exact mechanism(s) of the ergogenic effect of carbohydrate ingestion during exercise are not fully elucidated. However, it is likely that muscle glycogen sparing, liver glycogen sparing, and/or the maintenance of plasma glucose concentrations are involved, thereby allowing high $\mathrm{CHO}$ oxidation rates during the latter stages of exercise. The contribution of these factors may depend on the variables of the exercise bout (e.g. the intensity, duration, and type of exercise), the training status of the athlete, and the specifics of the carbohydrate feeding protocol.

\section{Exogenous carbohydrate oxidation}

There are many types of dietary carbohydrates, including monosaccharides such as glucose and fructose, disaccharides such as sucrose, and polysaccharides such as maltodextrin and starch [59]. The rate of gastric emptying, intestinal digestion, intestinal absorption, and hepatic metabolism of different carbohydrates may modulate their availability to skeletal muscle to be oxidized during exercise and/or used as a substrate for glycogen repletion. Carbohydrates can be divided in a group containing glucose and glucose polymers that are oxidized at rates up to 1.0-1.1 $\mathrm{g} \cdot \mathrm{min}^{-1}$ during exercise, and another group of fructose and galactose that are oxidized at a much lower rate up to $0.6 \mathrm{~g} \cdot \mathrm{min}^{-1}[7,60]$. Therefore, glucose or glucose polymers have generally been recommended as the preferred carbohydrate source during prolonged exercise. However, glucose or glucose polymer ingestion during exercise results in a maximal exogenous $\mathrm{CHO}$ oxidation rate of $1.0-1.1 \mathrm{~g} \cdot \mathrm{min}^{-1}$, even when the ingestion rate is much higher $[12,13]$. The rate of exogenous glucose oxidation appears limited by intestinal glucose absorption [12,61]. Glucose is absorbed from the intestine via sodium dependent glucose transporters (SGLT1) [62]. It has been speculated that glucose transport via SGLT1 may become saturated when more than 1-1.1 g. $\mathrm{min}^{-1}$ glucose and glucose polymers are ingested. However, fructose is absorbed independently from glucose by a distinct class of carbohydrate transporters, i.e. glucose transporter 5 (GLUT5) [63]. Due to the noncompetitive transport of glucose and fructose, the combined ingestion of glucose and fructose will increase total intestinal carbohydrate absorption rates and subsequent carbohydrate oxidation rates. In agreement, combined glucose and fructose ingestion has been shown to enhance intestinal carbohydrate absorption rates and results in higher exogenous $\mathrm{CHO}$ oxidation rates during exercise when compared with an equivalent amount of glucose $[14,15,63]$. Further support comes from the observation that a moderate amount of glucose and fructose does not result in higher exogenous $\mathrm{CHO}$ oxidation rates compared to an equivalent amount of glucose, suggesting that fructose co-ingestion only further increases exogenous $\mathrm{CHO}$ rates when maximal glucose absorption rates $\left(\sim 1.0-1.1 \mathrm{~g} \cdot \mathrm{min}^{-1}\right)$ are reached [64]. 

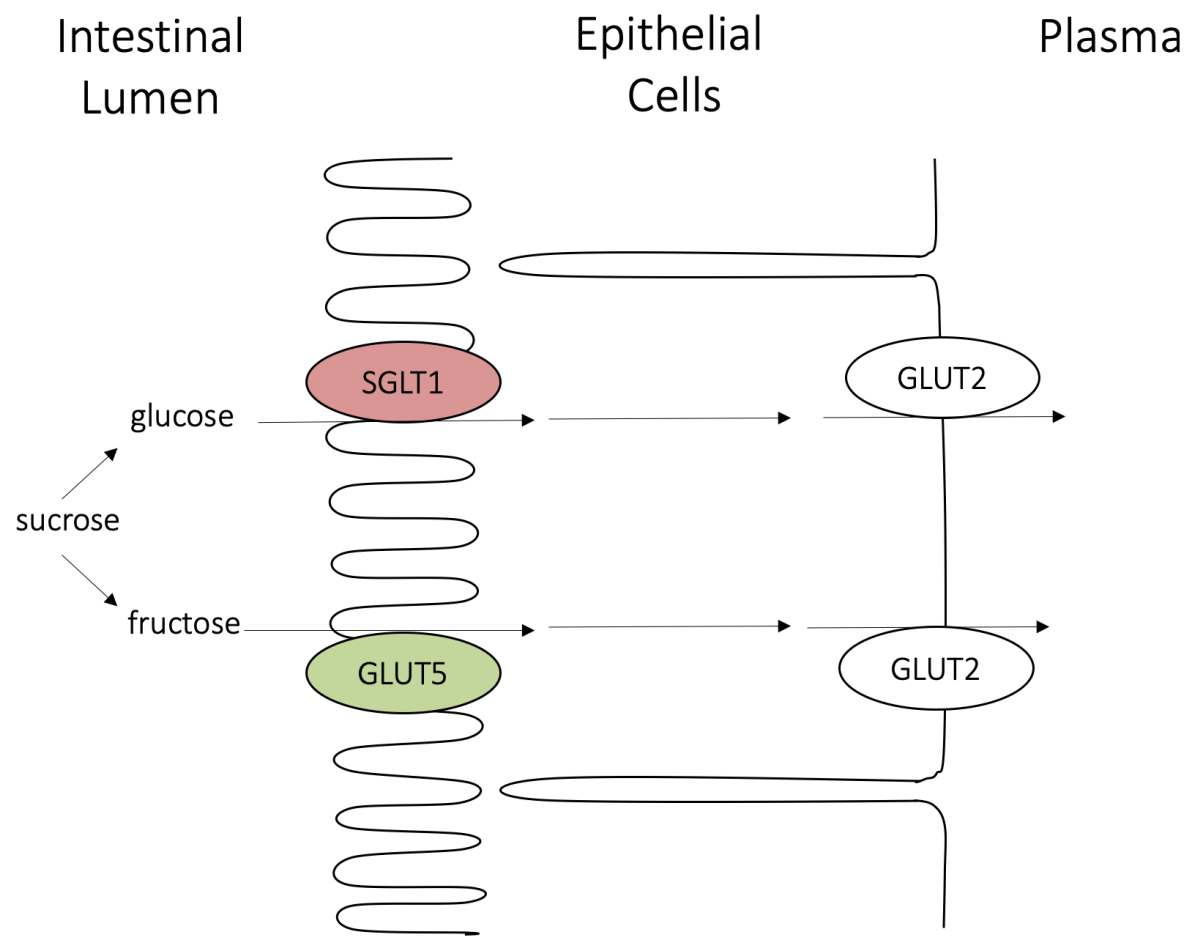

Figure 1.3 Intestinal carbohydrate absorption. The dissacharide sucrose is hydrolysed in a glucose and fructose monomer, which are transported across the epithelium by the sodium-glucose linked transporter 1 (SGLT1) and the glucose transporter 5 (GLUT5) transporters, respectively.

Sucrose combines glucose and fructose monomers, and its hydrolysis is typically not rate-limiting for intestinal absorption $[63,65]$. In addition, recent work suggests that intact sucrose can also be transported as a disaccharide across the intestinal membrane [66]. Therefore, sucrose may represent an (even more) effective dietary source of fructose co-ingestion. In agreement, sucrose has been shown to further increase exogenous carbohydrate oxidation rates during exercise compared to glucose only $[67,68]$. However, sucrose co-ingestion during exercise does not seem to elevate exogenous $\mathrm{CHO}$ oxidation rates beyond $1.2-1.3 \mathrm{~g} \cdot \mathrm{min}^{-1}[67,68]$, which is typically lower than $1.3-1.8 \mathrm{~g} \cdot \mathrm{min}^{-1}$ when fructose is co-ingested with glucose during exercise $[14,15,69,70]$. However, it should be noted that differences in exercise duration, training status of the subjects, and differences in the natural ${ }^{13} \mathrm{C}$ enrichment of carbohydrate sources may make direct comparison between exogenous $\mathrm{CHO}$ rates difficult. Future studies are needed to make a direct comparison between fructose and sucrose coingestion as nutritional strategies to increase exogenous $\mathrm{CHO}$ oxidation rates.

\section{Carbohydrate mouth rinsing}

The ergogenic properties of $\mathrm{CHO}$ ingestion during prolonged $(>2 \mathrm{~h}$ ), endurance-type exercise has been well established $[8,11,47]$. However, $\mathrm{CHO}$ ingestion has also been shown to improve performance during high-intensity exercise of a relative short duration ( $\leq 60 \mathrm{~min})[17,79]$, despite that endogenous $\mathrm{CHO}$ stores should not be a limiting factor for performance during exercise of such a short duration. Jeukendrup et al. reported a $2.3 \%$ improvement in $\sim 1$ h cycling time trial performance when carbohydrate was ingested regularly during exercise [17]. However, in a follow-up study, no ergogenic effect of an intravenous glucose infusion was observed during a 1-h cycling time trial [80], suggesting that systemic carbohydrate availability does not limit high-intensity exercise performance during exercise of such short duration. Therefore, the authors hypothesized that the presence of glucose in 
the oral cavity and/or gastrointestinal tract may also have some ergogenic properties. Subsequently, they demonstrated that repeated carbohydrate mouth rinses (swirling without ingestion) increased $~ 1$ h cycling time trial performance by $2.8 \%$ [81]. It is suggested that that the activation of oral carbohydrate receptors in the mouth activates brain regions related to reward and motivation [82]. Therefore, carbohydrate mouth rinsing may improve central drive and motivation, which may result in an improved ability to resist fatigue during exercise [82]. However, it can also be speculated that the cortisol response to carbohydrate mouth rising is attenuated by prior feeding, when liver glycogen stores are not compromised. It remains to be established whether the proposed ergogenic effect of carbohydrate mouth rinsing is attenuated in a fed state, which is more representative of a real-life setting.

\section{Post-exercise muscle glycogen resynthesis}

As previously discussed, muscle glycogen represents an essential substrate source during moderateto high-intensity endurance-type exercise contributing more than $50 \%$ of the total energy requirements $[1,3]$. Resting muscle glycogen stores range between $500-600 \mathrm{mg} \mathrm{kg}$ dry weight in trained athletes, but decrease by $50-75 \%$ during 180 min of cycling at $50-70 \% \mathrm{VO}_{2 \text { peak }}[59,71,72]$. Because of the association between fatigue and muscle glycogen depletion [5,39], the restoration of muscle glycogen stores during recovery from prolonged exercise is an important factor to enhance performance recovery in a subsequent exercise bout [40]. Depleted muscle glycogen stores can be completely restored within 24 $\mathrm{h}$ following prolonged exhaustive cycling exercise $[19,73]$. However, athletes do not always have $24 \mathrm{~h}$ to recover muscle glycogen stores, for example when multiple training sessions or multiple events (heats/finals) are planned, or during multi-day competition events such as the Tour the France. Therefore, much research has focused on increasing muscle glycogen restoration in the early postexercise recovery period ( $\leq 6 \mathrm{~h})$.

\section{Determinants of post-exercise glycogen synthesis}

Various factors have been identified that can modulate the post-exercise muscle glycogen resynthesis rate, including the timing, distribution, amount, and type of ingested $\mathrm{CHO}$. Muscle glycogen repletion rates are approximately $45 \%$ lower when $\mathrm{CHO}$ intake is delayed by $2 \mathrm{~h}$ compared to immediate postexercise $\mathrm{CHO}$ ingestion [21]. Initially, it was suggested that increasing $\mathrm{CHO}$ intake beyond 0.70-0.75 $\mathrm{g} \cdot \mathrm{kg}^{-1} \cdot \mathrm{h}^{-1}$ would not further augment post-exercise muscle glycogen repletion rates [22,74]. However, when carbohydrates are provided at more frequent intervals (i.e. every 15-30 min), post-exercise muscle glycogen repletion rates appear to be maximized when carbohydrates are ingested at a rate of 1.2 $\mathrm{g} \cdot \mathrm{kg}^{-1} \cdot \mathrm{h}^{-1}$ when provided every $30 \mathrm{~min}[24,25]$.

Several studies have observed lower post-exercise muscle glycogen repletion rates following the ingestion of fructose compared to glucose [74-76]. For example, van den Bergh et al. observed almost twofold higher muscle glycogen repletion rates when glucose was ingested compared to fructose during $8 \mathrm{~h}$ of post-exercise recovery [76]. The lower muscle glycogen repletion rate with fructose may be attributed to a slower absorption rate in the gut when compared to glucose, and/or the need for fructose to be converted into glucose and/or lactate in the liver before it can be utilized as substrate for muscle glycogen repletion in skeletal muscle tissue. However, glucose-fructose co-ingestion may represent an effective dietary strategy to optimize endogenous $\mathrm{CHO}$ repletion. In line with $\mathrm{CHO}$ intake during exercise, fructose co-ingestion may increase total $\mathrm{CHO}$ absorption rates in the intestine, thereby increasing the availability of $\mathrm{CHO}$ for post-exercise muscle glycogen repletion. Wallis et al. tested this 
hypothesis, but did not observe differences when $90 \mathrm{~g} \mathrm{CHO} \cdot \mathrm{h}^{-1}$ where ingested during $4 \mathrm{~h}$ of postexercise recovery provided either as glucose:fructose mix (2:1 ratio) or as glucose only [77]. However, it should be noted that the ingested amount of glucose in the glucose-fructose treatment $\left(60 \mathrm{~g} \cdot \mathrm{h}^{-1}\right.$ or $0.8 \mathrm{~g} \cdot \mathrm{kg}^{-1} \cdot \mathrm{h}^{-1}$ ) was below the recommended $1.2 \mathrm{~g} \cdot \mathrm{kg}^{-1} \cdot \mathrm{h}^{-1}$ required to maximize muscle glycogen repletion rates. Therefore, it could be speculated that the combined ingestion of glucose and fructose can augment post-exercise muscle glycogen repletion rates when ample glucose is provided $(\geq 1.2$ $\left.\mathrm{g} \cdot \mathrm{kg}^{-1} \cdot \mathrm{h}^{-1}\right)$. In addition, fructose may be a more effective $\mathrm{CHO}$ source to replete liver glycogen stores compared to glucose. For example, glucose-fructose co-ingestion has been shown to increase liver glycogen repletion rates when compared to an isocaloric amount of glucose only [78]. Therefore, more research is warranted in glucose-fructose co-ingestion to maximize total endogenous $\mathrm{CHO}$ stores (muscle and liver glycogen).

\section{Post-exercise muscle protein synthesis}

Besides the repletion of muscle glycogen stores, skeletal muscle damage repair and reconditioning are important determinants of post-exercise recovery. A positive net muscle protein balance provides an environment that can facilitate the repair of exercise-induced muscle damage and augment the skeletal muscle adaptive response to exercise training. A single session of exercise stimulates muscle protein synthesis rates, and to a lesser extent, muscle protein breakdown rates $[83,84]$. However, the muscle protein net balance will remain negative in the absence of food intake [84]. Protein ingestion stimulates muscle protein synthesis and inhibits muscle protein breakdown rates, resulting in a positive net muscle protein balance [85]. Therefore, post-exercise protein ingestion has become common practice to increase post-exercise muscle protein synthesis rates and, as such, to support the skeletal muscle adaptive response to exercise training.

\section{Determinants of muscle protein synthesis}

Multiple factors have been identified that can modulate the post-exercise muscle protein synthetic response to exercise including the amount [28,29], type [30,86], timing [87], and distribution [34] of protein ingestion. Moore et al. was the first to investigate the dose-response relationship between protein ingestion and muscle protein synthesis rates following resistance-type exercise [28]. Muscle protein synthesis rates following lower-body resistance-type exercise were significantly increased by the ingestion of $5 \mathrm{~g}$ egg protein and increased approximately linearly up to a dose of $20 \mathrm{~g}$ protein. Further increasing the amount of ingested protein to $40 \mathrm{~g}$ did not significantly further increase muscle protein synthesis rates. Therefore, the ingestion of $20 \mathrm{~g}$ protein ( $10 \mathrm{~g}$ essential amino acids) appears to be sufficient to maximize muscle protein synthesis rates following lower-body resistance-type exercise. This protein dose-response relationship appears to be similar for whey protein, in a rested state, and when a protein rich meal is provided $3 \mathrm{~h}$ before exercise [29]. However, more recent evidence indicates that this dose-response relationship may depend on the amount of muscle tissue that was recruited during exercise, with the ingestion of $40 \mathrm{~g}$ protein further increasing muscle protein synthesis rates during recovery from whole-body resistance-type exercise compared to the ingestion of $20 \mathrm{~g}$ protein [88]. Taking together, the ingestion of $20 \mathrm{~g}$ protein results in a near-maximal stimulation of post-exercise muscle protein synthesis rates, with a relatively small $10-20 \%$ further increase in postexercise muscle protein synthesis when protein intake is further increased to $40 \mathrm{~g}[28,29,88]$.

A large variety of dietary protein sources have been shown to stimulate post-exercise muscle protein synthesis rates, including egg protein [28], whey and casein protein [31], milk and beef protein [32], 
and soy protein [30]. However, dietary protein sources can differ in their capacity to stimulate muscle protein synthesis. For example, the ingestion of milk protein results in higher post-exercise muscle protein synthesis rates when compared to the ingestion of soy protein [86]. As most plant-based protein sources, soy protein has a lower essential amino content compared to animal-based sources, which may result in submaximal stimulation of muscle protein synthesis rates [89]. The amino acid leucine appears to be particularly potent at stimulating muscle protein synthesis, and the addition of small amounts of leucine can further increase the muscle protein synthetic response to protein ingestion $[90,91]$. Furthermore, the digestion and absorption rate of protein may also modulate the muscle protein synthetic response. Whey protein is a rapidly digestible protein, resulting in a more pronounced but transient increase in plasma amino acid concentrations. However, when whey protein is ingested in small pulses to reflect the plasma amino acid profile of a more slowly digestible protein, the muscle protein synthetic response is attenuated compared to bolus ingestion [92]. Therefore, the anabolic response to the ingestion of different protein sources appears to be largely dependent on differences in their digestion and absorption rates, and their amino acid composition.

In addition to the amount and type of ingested protein, the timing and distribution of protein ingestion throughout the day can modulate muscle protein synthesis rates. An even distribution of total protein intake over the three main meals stimulates $24-\mathrm{h}$ muscle protein synthesis rates more effectively than an unbalanced distribution in which the majority $(>60 \%)$ of total daily protein intake is consumed at the evening meal [93]. During $12 \mathrm{~h}$ of post-exercise recovery, an intermediate pattern of protein ingestion ( $20 \mathrm{~g}$ every $3 \mathrm{~h}$ ) appears to increase muscle protein synthesis rates to a greater extent than the same amount of protein provided in less frequent but larger amounts $40 \mathrm{~g}$ every 6 h), or in more frequent, smaller amounts (10 g every 6 h) [34]. Therefore, an effective pattern of daily protein intake distribution to support muscle protein synthesis throughout the day is to provide at least $20 \mathrm{~g}$ of protein with each main meal with no more than $4-5 \mathrm{~h}$ between meals.

\section{Overnight muscle protein synthesis rates}

As most athletes eat relative large amounts of protein, muscle protein synthesis rates likely exceed muscle protein breakdown rates during most of the day. However, overnight sleep is typically the longest post-absorptive period during the day and may represent a prolonged period of a negative net muscle protein balance. Indeed, post-exercise overnight muscle protein synthesis rates are low even when relatively large amounts of protein are consumed during daytime $\left(1.7 \mathrm{~g} \cdot \mathrm{kg}^{-1} \cdot \mathrm{d}^{-1}\right)$ [94]. Overnight muscle protein synthesis rates are likely restricted by the level of amino acid availability. Therefore, pre-sleep protein ingestion has recently been introduced as a strategy to increase overnight muscle protein synthesis rates (Figure 1.4).

Specifically, after a full day of dietary standardization, subjects performed a single session of resistancetype exercise in the evening [35]. Immediately after exercise (21:00 h), all subjects ingested $20 \mathrm{~g}$ protein to maximize muscle protein synthesis rates during the acute post-exercise recovery period. In addition, subjects ingested either a protein drink or a placebo immediately prior to sleep (11:30 h). The protein was effectively digested and absorbed, resulting elevated amino acid levels throughout the overnight period. In line, muscle protein synthesis rates were approximately $22 \%$ higher when compared to the placebo treatment. These data suggest that protein ingestion prior to sleep represents an effective dietary strategy to increase exercise recovery and augment the skeletal muscle adaptive response to exercise. A follow-up study assessed this hypothesis by assessing the impact of protein intake prior to sleep on muscle hypertrophic response during prolonged exercise training [36]. Specifically, subjects 
participated in a 12-week resistance-type exercise training program (three training sessions per week) during which they either ingested $27.5 \mathrm{~g}$ protein prior to sleep, or a placebo. Pre-sleep protein ingestion resulted in greater muscle mass and strength gains when compared to placebo ingestion. These results demonstrate that protein ingestion prior to sleep represent an effective dietary strategy to augment the skeletal muscle adaptive response to resistance-type exercise training. Further studies are needed to identify the amount and type of protein required to optimize overnight muscle protein synthesis rates. In addition, more research is warranted to determine if this feeding strategy can increase muscle reconditioning following other exercise modalities or whether it may also support muscle mass maintenance or gain in healthy older populations or clinically compromised patient populations.
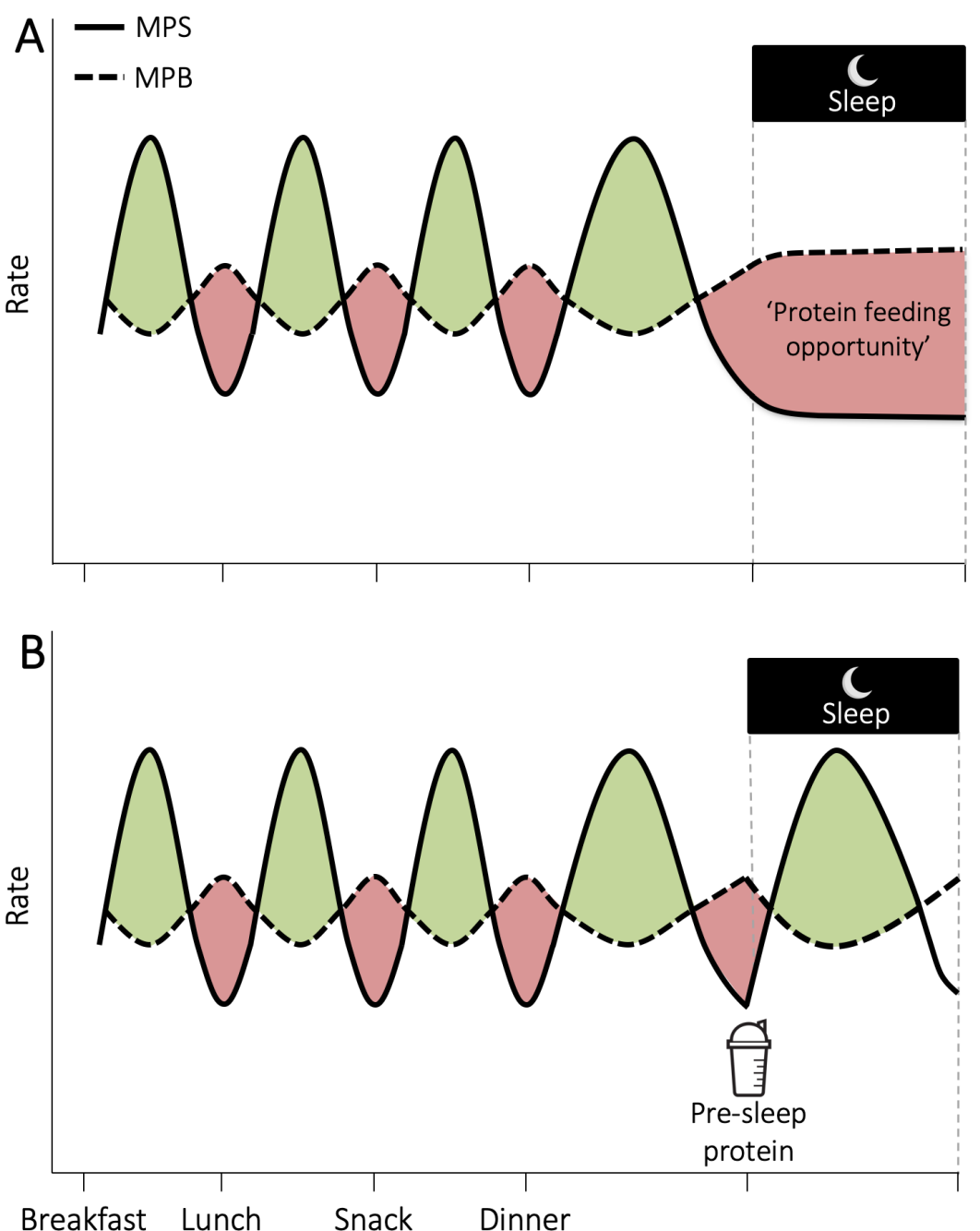

Figure 1.4 Schematic representation of the process of muscle protein synthesis (MPS) and muscle protein breakdown (MPB) throughout the day. Protein ingestion stimulates MPS rates and allows for net muscle protein accretion (green areas). During post-absorptive conditions, MPB rates exceed MPS rates, resulting in a net loss of muscle protein (red areas). Overnight sleep is the longest post-absorptive period of the day (A). Pre-sleep protein ingestion stimulates overnight muscle protein synthesis rates (B), thereby improving muscle reconditioning throughout overnight sleep. From Trommelen et al., Nutrients, 2017 [95] 


\section{Outline of this thesis}

This thesis describes a series of studies that were designed to investigate the impact of carbohydrate and/or protein ingestion to improve exercise performance, recovery and/or the adaptive response to exercise. In Chapter 2 we have determined the impact of the combined ingestion of fructose or sucrose with glucose to increase exogenous carbohydrate oxidation rates during prolonged endurance-type exercise. In Chapter 3 we examined the efficacy of carbohydrate mouth rinsing to increase endurancetype exercise performance in a fasted or fed state. In Chapter 4 the impact of the combined ingestion of fructose or sucrose with glucose were assessed on post-exercise muscle glycogen repletion rates. In Chapter 5 we characterized the protein intake and distribution pattern of well-trained athletes. In Chapter 6 we investigated the impact of prior exercise on the muscle protein synthetic response to pre-sleep protein ingestion. Chapter 7 addresses the impact of protein ingestion prior to sleep as a strategy to improve overnight muscle protein synthesis rates. Finally, in Chapter 8 the results of the previous chapters are being discussed and placed in a broader perspective. The applicability of carbohydrate and/or protein ingestion as nutritional strategies to improve exercise performance, recovery and/or the adaptive response to exercise will be discussed and future research aims will be defined. 


\section{REFERENCES}

1. Romijn JA, Coyle EF, Sidossis LS, Gastaldelli A, Horowitz JF, Endert E, et al. Regulation of endogenous fat and carbohydrate metabolism in relation to exercise intensity and duration. Am J Physiol. 1993;265:E380-91.

2. van Loon $L J$, Jeukendrup $A E$, Saris $W H$, Wagenmakers AJ. Effect of training status on fuel selection during submaximal exercise with glucose ingestion. J Appl Physiol (1985). 1999;87:1413-20.

3. van Loon LJ, Greenhaff PL, Constantin-Teodosiu D, Saris WH, Wagenmakers AJ. The effects of increasing exercise intensity on muscle fuel utilisation in humans. J Physiol. 2001;536:295-304.

4. McArdle WD, Katch Fl, Katch VL. Exercise physiology: nutrition, energy, and human performance. Lippincott Williams \& Wilkins; 2010.

5. Bergstrom J, Hultman E. A study of the glycogen metabolism during exercise in man. Scand. J. Clin. Lab. Invest. 1967;19:218-28.

6. Stellingwerff T, Cox GR. Systematic review: Carbohydrate supplementation on exercise performance or capacity of varying durations. Appl. Physiol. Nutr. Metab. 2014;39:998-1011.

7. Cermak NM, van Loon LJC. The use of carbohydrates during exercise as an ergogenic aid. Sports Med. 2013;43:1139-55.

8. Coyle EF, Hagberg JM, Hurley BF, Martin WH, Ehsani AA, Holloszy JO. Carbohydrate feeding during prolonged strenuous exercise can delay fatigue. J Appl Physiol (1985). 1983;55:230-5.

9. Hargreaves M, Costill DL, Coggan A, Fink WJ, Nishibata I. Effect of carbohydrate feedings on muscle glycogen utilization and exercise performance. Medicine \& Science in Sports \& Exercise. 1984;16:219-22.

10. Mitchell JB, Costill DL, Houmard JA, Flynn MG, Fink WJ, Beltz JD. Effects of carbohydrate ingestion on gastric emptying and exercise performance. Medicine \& Science in Sports \& Exercise. 1988;20:110-5.

11. Neufer PD, Costill DL, Flynn MG, Kirwan JP, Mitchell JB, Houmard J. Improvements in exercise performance: effects of carbohydrate feedings and diet. J Appl Physiol (1985). 1987;62:983-8.

12. Jeukendrup AE, Wagenmakers AJ, Stegen JH, Gijsen AP, Brouns F, Saris WH. Carbohydrate ingestion can completely suppress endogenous glucose production during exercise. Am J Physiol. 1999;276:E672-83.

13. Jeukendrup $A E$, Jeukendrup. Oxidation of Carbohydrate Feedings During Prolonged Exercise. 2012;:1-18.

14. Jentjens RLPG, Moseley L, Waring RH, Harding LK, Jeukendrup AE. Oxidation of combined ingestion of glucose and fructose during exercise. J Appl Physiol (1985). 2004;96:1277-84.

15. Wallis GA, Rowlands DS, Shaw C, Jentjens RLPG, Jeukendrup AE. Oxidation of Combined Ingestion of Maltodextrins and Fructose during Exercise. Medicine \& Science in Sports \& Exercise. 2005;37:426-32.

16. Below PR, Mora-Rodriguez R, Gonzalez-Alonso J, Coyle EF. Fluid and carbohydrate ingestion independently improve performance during $1 \mathrm{~h}$ of intense exercise. Medicine \& Science in Sports \& Exercise. 1995;27:200-10.

17. Jeukendrup A, Brouns F, Wagenmakers AJ, Saris WH. Carbohydrate-electrolyte feedings improve $1 \mathrm{~h}$ time trial cycling performance. Int J Sports Med. 1997;18:125-9. 
18. Anantaraman R, Carmines AA, Gaesser GA, Weltman A. Effects of carbohydrate supplementation on performance during 1 hour of high-intensity exercise. Int J Sports Med. 1995;16:461-5.

19. Casey A, Short AH, Hultman E, Greenhaff PL. Glycogen resynthesis in human muscle fibre types following exercise-induced glycogen depletion. J Physiol. 1995;483 ( Pt 1):265-71.

20. Costill DL, Sherman WM, Fink WJ, Maresh C, Witten M, Miller JM. The role of dietary carbohydrates in muscle glycogen resynthesis after strenuous running. Am J Clin Nutr. 1981;34:1831-6.

21. Ivy JL, Katz AL, Cutler CL, Sherman WM, Coyle EF. Muscle glycogen synthesis after exercise: effect of time of carbohydrate ingestion. J Appl Physiol (1985). 1988;64:1480-5.

22. Ivy JL, Lee MC, Brozinick JTJ, Reed MJ. Muscle glycogen storage after different amounts of carbohydrate ingestion. J Appl Physiol (1985). 1988;65:2018-23.

23. Reed MJ, Brozinick JTJ, Lee MC, Ivy JL. Muscle glycogen storage postexercise: effect of mode of carbohydrate administration. J Appl Physiol (1985). 1989;66:720-6.

24. van Loon LJ, Saris WH, Kruijshoop M, Wagenmakers AJ. Maximizing postexercise muscle glycogen synthesis: carbohydrate supplementation and the application of amino acid or protein hydrolysate mixtures. Am J Clin Nutr. 2000;72:106-11.

25. Howarth KR, Moreau NA, Phillips SM, Gibala MJ. Coingestion of protein with carbohydrate during recovery from endurance exercise stimulates skeletal muscle protein synthesis in humans. J Appl Physiol (1985). 2009;106:1394-402.

26. Borsheim E, Tipton KD, Wolf SE, Wolfe RR. Essential amino acids and muscle protein recovery from resistance exercise. Am J Physiol Endocrinol Metab. 2002;283:E648-57.

27. Biolo G, Tipton KD, Klein S, Wolfe RR. An abundant supply of amino acids enhances the metabolic effect of exercise on muscle protein. Am J Physiol. 1997;273:E122-9.

28. Moore DR, Robinson MJ, Fry JL, Tang JE, Glover El, Wilkinson SB, et al. Ingested protein dose response of muscle and albumin protein synthesis after resistance exercise in young men. Am J Clin Nutr. 2009;89:161-8.

29. Witard OC, Jackman SR, Breen L, Smith K, Selby A, Tipton KD. Myofibrillar muscle protein synthesis rates subsequent to a meal in response to increasing doses of whey protein at rest and after resistance exercise. Am J Clin Nutr. 2013;99:86-95.

30. Tang JE, Moore DR, Kujbida GW, Tarnopolsky MA, Phillips SM. Ingestion of whey hydrolysate, casein, or soy protein isolate: effects on mixed muscle protein synthesis at rest and following resistance exercise in young men. J Appl Physiol (1985). 2009;107:987-92.

31. Tipton KD, Elliott TA, Cree MG, Wolf SE, Sanford AP, Wolfe RR. Ingestion of casein and whey proteins result in muscle anabolism after resistance exercise. Medicine \& Science in Sports \& Exercise. 2004;36:2073-81.

32. Burd NA, Gorissen SH, van Vliet S, Snijders T, van Loon LJ. Differences in postprandial protein handling after beef compared with milk ingestion during postexercise recovery: a randomized controlled trial. Am J Clin Nutr. 2015;102:828-36.

33. Burd NA, West DWD, Moore DR, Atherton PJ, Staples AW, Prior T, et al. Enhanced amino acid sensitivity of myofibrillar protein synthesis persists for up to $24 \mathrm{~h}$ after resistance exercise in young men. J Nutr. 2011;141:568-73. 
34. Areta JL, Burke LM, Ross ML, Camera DM, West DWD, Broad EM, et al. Timing and distribution of protein ingestion during prolonged recovery from resistance exercise alters myofibrillar protein synthesis. J Physiol. 2013;591:2319-31.

35. Res PT, Groen B, Pennings B, Beelen M, Wallis GA, Gijsen AP, et al. Protein ingestion before sleep improves postexercise overnight recovery. Medicine \& Science in Sports \& Exercise. 2012;44:1560-9.

36. Snijders T, Res PT, Smeets JSJ, van Vliet $S$, van KRANENBURG J, Maase $K$, et al. Protein Ingestion before Sleep Increases Muscle Mass and Strength Gains during Prolonged Resistance-Type Exercise Training in Healthy Young Men. J Nutr. American Society for Nutrition; 2015;145:1178-84.

37. Nielsen JN, Wojtaszewski JFP, Haller RG, Hardie DG, Kemp BE, Richter EA, et al. Role of 5"AMP-activated protein kinase in glycogen synthase activity and glucose utilization: insights from patients with McArdle"s disease. J Physiol. 2002;541:979-89.

38. Lucia A, Ruiz JR, Santalla A, Nogales-Gadea G, Rubio JC, Garcia-Consuegra I, et al. Genotypic and phenotypic features of McArdle disease: insights from the Spanish national registry. $J$ Neurol Neurosurg Psychiatry. 2012;83:322-8.

39. Bergstrom J, Hermansen L, Hultman E, Saltin B. Diet, muscle glycogen and physical performance. Acta Physiologica Scandinavica. Blackwell Publishing Ltd; 1967;71:140-50.

40. Alghannam AF, Jedrzejewski D, Tweddle MG, Gribble H, Bilzon J, Thompson D, et al. Impact of Muscle Glycogen Availability on the Capacity for Repeated Exercise in Man. Medicine \& Science in Sports \& Exercise. 2016;48:123-31.

41. Tsintzas K, Williams C. Human muscle glycogen metabolism during exercise. Effect of carbohydrate supplementation. Sports Med. 1998;25:7-23.

42. Bjorkman O, Sahlin K, Hagenfeldt L, Wahren J. Influence of glucose and fructose ingestion on the capacity for long-term exercise in well-trained men. Clin Physiol. 1984;4:483-94.

43. Tsintzas OK, Williams C, Boobis L, Greenhaff P. Carbohydrate ingestion and glycogen utilization in different muscle fibre types in man. J Physiol. 1995;489 ( Pt 1):243-50.

44. Tsintzas K, Williams C, Constantin-Teodosiu D, Hultman E, Boobis L, Clarys P, et al. Phosphocreatine degradation in type I and type II muscle fibres during submaximal exercise in man: effect of carbohydrate ingestion. J Physiol. 2001;537:305-11.

45. Erickson MA, Schwarzkopf RJ, McKenzie RD. Effects of caffeine, fructose, and glucose ingestion on muscle glycogen utilization during exercise. Medicine \& Science in Sports \& Exercise. 1987;19:579-83.

46. Stellingwerff $T$, Boon $H$, Gijsen AP, Stegen JHCH, Kuipers H, van Loon LJC. Carbohydrate supplementation during prolonged cycling exercise spares muscle glycogen but does not affect intramyocellular lipid use. Pflugers Arch. 2007;454:635-47.

47. Coyle EF, Coggan AR, Hemmert MK, Ivy JL. Muscle glycogen utilization during prolonged strenuous exercise when fed carbohydrate. J Appl Physiol (1985). 1986;61:165-72.

48. Flynn MG, Costill DL, Hawley JA, Fink WJ, Neufer PD, Fielding RA, et al. Influence of selected carbohydrate drinks on cycling performance and glycogen use. Medicine \& Science in Sports \& Exercise. 1987;19:37-40.

49. Mitchell JB, Costill DL, Houmard JA, Fink WJ, Pascoe DD, Pearson DR. Influence of carbohydrate dosage on exercise performance and glycogen metabolism. J Appl Physiol (1985). 1989;67:1843-9. 
50. Hargreaves M, Briggs CA. Effect of carbohydrate ingestion on exercise metabolism. J Appl Physiol (1985). 1988;65:1553-5.

51. Gonzalez JT, Fuchs CJ, Smith FE, Thelwall PE, Taylor R, Stevenson EJ, et al. Ingestion of glucose or sucrose prevents liver but not muscle glycogen depletion during prolonged endurance-type exercise in trained cyclists. Am J Physiol Endocrinol Metab. 2015;309:E10329.

52. Gollnick PD, Piehl K, Saltin B. Selective glycogen depletion pattern in human muscle fibres after exercise of varying intensity and at varying pedalling rates. J Physiol. 1974;241:45-57.

53. Casey A, Mann R, Banister K, Fox J, Morris PG, Macdonald IA, et al. Effect of carbohydrate ingestion on glycogen resynthesis in human liver and skeletal muscle, measured by (13)C MRS. Am J Physiol Endocrinol Metab. 2000;278:E65-75.

54. Bergman BC, Horning MA, Casazza GA, Wolfel EE, Butterfield GE, Brooks GA. Endurance training increases gluconeogenesis during rest and exercise in men. Am J Physiol Endocrinol Metab. 2000;278:E244-51.

55. Stevenson EJ, Thelwall PE, Thomas K, Smith F, Brand-Miller J, Trenell MI. Dietary glycemic index influences lipid oxidation but not muscle or liver glycogen oxidation during exercise. Am J Physiol Endocrinol Metab. 2009;296:E1140-7.

56. Coggan AR, Coyle EF. Reversal of fatigue during prolonged exercise by carbohydrate infusion or ingestion. J Appl Physiol (1985). 1987;63:2388-95.

57. Claassen A, Lambert EV, Bosch AN, Rodger LM, St Clair Gibson A, Noakes TD. Variability in exercise capacity and metabolic response during endurance exercise after a low carbohydrate diet. Int J Sport Nutr Exerc Metab. 2005;15:97-116.

58. Felig P, Cherif A, Minagawa A, Wahren J. Hypoglycemia during prolonged exercise in normal men. N Engl J Med. 1982;306:895-900.

59. Gonzalez JT, Fuchs CJ, Betts JA, van Loon LJC. Glucose Plus Fructose Ingestion for PostExercise Recovery-Greater than the Sum of Its Parts? Nutrients. 2017;9.

60. Jeukendrup $A E$, Jentjens R. Oxidation of carbohydrate feedings during prolonged exercise: current thoughts, guidelines and directions for future research. Sports Med. 2000;29:407-24.

61. Jeukendrup AE. Carbohydrate and exercise performance: the role of multiple transportable carbohydrates. Curr Opin Clin Nutr Metab Care. 2010;13:452-7.

62. Daniel $\mathrm{H}$, Zietek T. Taste and move: glucose and peptide transporters in the gastrointestinal tract. Exp Physiol. 2015;100:1441-50.

63. Shi X, Summers RW, Schedl HP, Flanagan SW, Chang R, Gisolfi CV. Effects of carbohydrate type and concentration and solution osmolality on water absorption. Medicine \& Science in Sports \& Exercise. 1995;27:1607-15.

64. Hulston $\mathrm{CJ}$, Wallis GA, Jeukendrup $\mathrm{AE}$. Exogenous $\mathrm{CHO}$ oxidation with glucose plus fructose intake during exercise. Medicine \& Science in Sports \& Exercise. 2009;41:357-63.

65. Wallis GA, Wittekind $A$. Is there a specific role for sucrose in sports and exercise performance? Int J Sport Nutr Exerc Metab. 2013;23:571-83.

66. Likely R, Johnson E, Ahearn GA. Functional characterization of a putative disaccharide membrane transporter in crustacean intestine. J Comp Physiol B. 2015;185:173-83.

67. Jentjens RLPG, Venables MC, Jeukendrup AE. Oxidation of exogenous glucose, sucrose, and maltose during prolonged cycling exercise. J Appl Physiol (1985). 2004;96:1285-91. 
68. Jentjens RLPG, Shaw C, Birtles T, Waring RH, Harding LK, Jeukendrup AE. Oxidation of combined ingestion of glucose and sucrose during exercise. Metabolism. 2005;54:610-8.

69. Jentjens RLPG, Jeukendrup AE. High rates of exogenous carbohydrate oxidation from a mixture of glucose and fructose ingested during prolonged cycling exercise. Br J Nutr. 2005;93:485-92.

70. Roberts JD, Tarpey MD, Kass LS, Tarpey RJ, Roberts MG. Assessing a commercially available sports drink on exogenous carbohydrate oxidation, fluid delivery and sustained exercise performance. J Int Soc Sports Nutr. 2014;11:8.

71. Bosch AN, Weltan SM, Dennis SC, Noakes TD. Fuel substrate turnover and oxidation and glycogen sparing with carbohydrate ingestion in non-carbohydrate-loaded cyclists. Pflugers Arch. 1996;432:1003-10.

72. Bosch AN, Dennis SC, Noakes TD. Influence of carbohydrate ingestion on fuel substrate turnover and oxidation during prolonged exercise. J Appl Physiol (1985). 1994;76:2364-72.

73. Keizer HA. Influence of Liquid and Solid Meals on Muscle Glycogen Resynthesis, plasma fuel hormone response, and maximal physical working capacity. Int J Sports Med. 1987;8:99-104.

74. Blom PC, Hostmark AT, Vaage O, Kardel KR, Maehlum S. Effect of different post-exercise sugar diets on the rate of muscle glycogen synthesis. Medicine \& Science in Sports \& Exercise. $1987 ; 19: 491-6$.

75. Conlee RK, Lawler RM, Ross PE. Effects of glucose or fructose feeding on glycogen repletion in muscle and liver after exercise or fasting. Ann Nutr Metab. 1987;31:126-32.

76. Van Den Bergh AJ, Houtman S, Heerschap A, Rehrer NJ, Van Den Boogert HJ, Oeseburg B, et al. Muscle glycogen recovery after exercise during glucose and fructose intake monitored by 13C-NMR. J Appl Physiol (1985). 1996;81:1495-500.

77. Wallis GA, Hulston CJ, Mann CH, Roper HP, Tipton KD, Jeukendrup AE. Postexercise muscle glycogen synthesis with combined glucose and fructose ingestion. Medicine \& Science in Sports \& Exercise. 2008;40:1789-94.

78. Décombaz J, Jentjens R, Ith $M$, Scheurer E, Buehler T, Jeukendrup A, et al. Fructose and galactose enhance postexercise human liver glycogen synthesis. Medicine \& Science in Sports \& Exercise. 2011;43:1964-71.

79. Below PR, Mora-Rodriguez R, Gonzalez-Alonso J, Coyle EF. Fluid and carbohydrate ingestion independently improve performance during $1 \mathrm{~h}$ of intense exercise. Medicine \& Science in Sports \& Exercise. 1995;27:200-10.

80. Carter JM, Jeukendrup AE, Mann CH, Jones DA. The effect of glucose infusion on glucose kinetics during a 1-h time trial. Medicine \& Science in Sports \& Exercise. 2004;36:1543-50.

81. Carter JM, Jeukendrup AE, Jones DA. The effect of carbohydrate mouth rinse on 1-h cycle time trial performance. Medicine \& Science in Sports \& Exercise. 2004;36:2107-11.

82. Chambers ES, Bridge MW, Jones DA. Carbohydrate sensing in the human mouth: effects on exercise performance and brain activity. J Physiol. 2009;587:1779-94.

83. Biolo G, Maggi SP, Williams BD, Tipton KD, Wolfe RR. Increased rates of muscle protein turnover and amino acid transport after resistance exercise in humans. Am J Physiol. 1995;268:E514-20.

84. Phillips SM, Tipton KD, Aarsland A, Wolf SE, Wolfe RR. Mixed muscle protein synthesis and breakdown after resistance exercise in humans. Am J Physiol. 1997;273:E99-107. 
85. Tipton KD, Ferrando AA, Phillips SM, Doyle DJ, Wolfe RR. Postexercise net protein synthesis in human muscle from orally administered amino acids. Am J Physiol. 1999;276:E628-34.

86. Wilkinson SB, Tarnopolsky MA, Macdonald MJ, Macdonald JR, Armstrong D, Phillips SM. Consumption of fluid skim milk promotes greater muscle protein accretion after resistance exercise than does consumption of an isonitrogenous and isoenergetic soy-protein beverage. Am J Clin Nutr. 2007;85:1031-40.

87. Levenhagen DK, Gresham JD, Carlson MG, Maron DJ, Borel MJ, Flakoll PJ. Postexercise nutrient intake timing in humans is critical to recovery of leg glucose and protein homeostasis. Am J Physiol Endocrinol Metab. 2001;280:E982-93.

88. Macnaughton LS, Wardle SL, Witard OC, McGlory C, Hamilton DL, Jeromson S, et al. The response of muscle protein synthesis following whole-body resistance exercise is greater following $40 \mathrm{~g}$ than $20 \mathrm{~g}$ of ingested whey protein. Physiol Rep. 2016;4.

89. van Vliet S, Burd NA, van Loon LJ. The Skeletal Muscle Anabolic Response to Plant- versus Animal-Based Protein Consumption. J Nutr. 2015;145:1981-91.

90. Churchward-Venne TA, Breen L, Di Donato DM, Hector AJ, Mitchell CJ, Moore DR, et al. Leucine supplementation of a low-protein mixed macronutrient beverage enhances myofibrillar protein synthesis in young men: a double-blind, randomized trial. Am J Clin Nutr. 2014;99:27686.

91. Wall BT, Hamer HM, de Lange A, Kiskini A, Groen BBL, Senden JMG, et al. Leucine coingestion improves post-prandial muscle protein accretion in elderly men. Clin Nutr. 2013;32:412-9.

92. West DWD, Burd NA, Coffey VG, Baker SK, Burke LM, Hawley JA, et al. Rapid aminoacidemia enhances myofibrillar protein synthesis and anabolic intramuscular signaling responses after resistance exercise. Am J Clin Nutr. 2011;94:795-803.

93. Mamerow MM, Mettler JA, English KL, Casperson SL, Arentson-Lantz E, Sheffield-Moore M, et al. Dietary protein distribution positively influences $24-\mathrm{h}$ muscle protein synthesis in healthy adults. J Nutr. 2014;144:876-80.

94. Beelen M, Tieland M, Gijsen AP, Vandereyt $H$, Kies AK, Kuipers $H$, et al. Coingestion of carbohydrate and protein hydrolysate stimulates muscle protein synthesis during exercise in young men, with no further increase during subsequent overnight recovery. J Nutr. 2008;138:2198-204.

95. Trommelen J, van Loon LJC. Pre-Sleep Protein Ingestion to Improve the Skeletal Muscle Adaptive Response to Exercise Training. Nutrients. 2016;8. 



\section{Chapter 2}

Fructose and sucrose intake increase exogenous carbohydrate oxidation during exercise

Jorn Trommelen; Cas J. Fuchs; Milou Beelen; Kaatje Lenaerts; Asker E. Jeukendrup; Naomi M. Cermak; Luc J.C. van Loon

Nutrients. 2017 Feb;20:9(2) 


\section{ABSTRACT}

Background: Peak exogenous carbohydrate oxidation rates typically reach $\sim 1 \mathrm{~g} \cdot \mathrm{min}^{-1}$ during exercise when ample glucose or glucose polymers are ingested. Fructose co-ingestion has been shown to further increase exogenous carbohydrate oxidation rates.

Purpose: To assess the impact of fructose co-ingestion provided either as a monosaccharide or as part of the disaccharide sucrose on exogenous carbohydrate oxidation rates during prolonged exercise in trained cyclists.

Methods: Ten trained male cyclists $\left(\mathrm{VO}_{2}\right.$ peak: $\left.65 \pm 2 \mathrm{~mL} \cdot \mathrm{kg}^{-1} \cdot \mathrm{min}^{-1}\right)$ cycled on 4 different occasions for $180 \mathrm{~min}$ at $50 \% \mathrm{~W}_{\max }$ during which they consumed a carbohydrate solution providing $1.8 \mathrm{~g} \cdot \mathrm{min}^{-1}$ of glucose (GLU), $1.2 \mathrm{~g} \cdot \mathrm{min}^{-1}$ glucose $+0.6 \mathrm{~g} \cdot \mathrm{min}^{-1}$ fructose $(G L U+F R U), 0.6 \mathrm{~g} \cdot \mathrm{min}^{-1}$ glucose $+1.2 \mathrm{~g} \cdot \mathrm{min}^{-1}$ sucrose (GLU+SUC), or water (WAT).

Results: Peak exogenous carbohydrate oxidation rates did not differ between GLU+FRU and GLU+SUC (1.40 \pm 0.06 vs $1.29 \pm 0.07 \mathrm{~g} \cdot \mathrm{min}^{-1}$, respectively, $\left.P=0.999\right)$, but were $46 \pm 8 \%$ higher when compared to GLU $\left(0.96 \pm 0.06 \mathrm{~g} \cdot \mathrm{min}^{-1}: P<0.05\right)$. In line, exogenous carbohydrate oxidation rates during the latter 120 min of exercise were $46 \pm 8 \%$ higher in GLU+FRU or GLU+SUC compared with GLU (1.19 \pm 0.12 , $1.13 \pm 0.21$, and $0.82 \pm 0.16 \mathrm{~g} \cdot \mathrm{min}^{-1}$, respectively, $P<0.05$ ).

Conclusion: Fructose co-ingestion $\left(0.6 \mathrm{~g} \cdot \mathrm{min}^{-1}\right)$ with glucose $\left(1.2 \mathrm{~g} \cdot \mathrm{min}^{-1}\right)$ provided either as monosaccharide or as sucrose strongly increases exogenous carbohydrate oxidation rates during prolonged exercise in trained cyclists. 


\section{INTRODUCTION}

It has been well established that carbohydrate ingestion during prolonged moderate- to high-intensity endurance-type exercise increases exercise capacity and performance [1-3]. The observed improvements in performance with carbohydrate ingestion have been attributed to maintenance of plasma glucose concentrations and high rates of carbohydrate oxidation during the latter stages of exercise $[1,4]$.

Glucose ingestion during exercise results in a maximal exogenous carbohydrate oxidation rate of $\sim 1$ $g \cdot \min ^{-1}[5,6]$. The rate of exogenous glucose oxidation appears limited by intestinal glucose absorption $[5,7]$. The intestinal sodium-dependent glucose transporter 1 (SGLT1) may become saturated when large amounts of glucose or glucose polymers are ingested $[7,8]$. Interestingly, the intestine contains a distinct class of carbohydrate transporters, glucose transporter 5 (GLUT5), that absorbs fructose and most likely fructose released during the hydrolysis from the disaccharide sucrose [9-11]. More recently, other intestinal carbohydrate transporters have been implicated in glucose (GLUT2) and fructose (GLUT2, GLUT8, GLUT 12) absorption [12-14]. Because of the distinct transport routes for glucose and fructose, higher total intestinal carbohydrate absorption rates can be expected when glucose and fructose are co-ingested. In agreement, combined glucose and fructose ingestion has been shown to enhance intestinal carbohydrate absorption rates and results in higher exogenous carbohydrate oxidation rates during exercise compared with an equivalent amount of glucose $[8,15,16]$.

Sucrose combines glucose and fructose monomers, and its hydrolysis is typically not rate limiting for intestinal absorption [15,17]. In addition, recent work suggests that intact sucrose can also be transported as a disaccharide across the intestinal membrane [18]. Therefore, sucrose may represent an (even more) effective dietary source of fructose co-ingestion. In agreement, sucrose co-ingestion has been shown to further increase exogenous carbohydrate oxidation rates during exercise compared to glucose only $[19,20]$. However, sucrose co-ingestion during exercise does not seem to elevate exogenous carbohydrate oxidation rates beyond $1.2-1.3 \mathrm{~g} \cdot \mathrm{min}^{-1}[19,20]$, which is typically lower than 1.3-1.8 $\mathrm{g} \cdot \mathrm{min}^{-1}$ when fructose is co-ingested with glucose during exercise $[8,16,21,22]$. Exogenous carbohydrate oxidation rates do not appear to level off when increasing amounts of fructose are coingested [21]. In contrast, exogenous carbohydrate oxidation rates have been shown to plateau when moderate amounts of sucrose are co-ingested [19]. This may suggest that sucrose digestion and/or absorption becomes a limiting factor when large amounts of sucrose are co-ingested. Therefore, it remains unclear whether sucrose co-ingestion can be as effective as fructose co-ingestion to further augment exogenous carbohydrate oxidation rates when glucose ingestion is increased above 1.0-1.1 $\mathrm{g} \cdot \mathrm{min}^{-1}$.

We have recently shown that endurance-type exercise induces splanchnic hypoperfusion, resulting in a rapid increase in plasma I-FABP, a novel biomarker of intestinal damage [23]. Hypoperfusion-induced intestinal compromise may hamper athletic performance and can jeopardize early postexercise recovery [24]. Meal ingestion and intestinal nutrient supply have the ability to increase the superior mesenteric artery blood flow and, hence, splanchnic perfusion $[25,26]$. Therefore, carbohydrate ingestion during endurance-type exercise may represent an effective nutritional strategy to attenuate splanchnic hypoperfusion and, as such, prevent exercise-induced gastrointestinal injury. 
The present study assesses the impact of the combined ingestion of fructose or sucrose with glucose on exogenous carbohydrate oxidation rates. We hypothesized that both fructose and sucrose coingestion augment exogenous carbohydrate oxidation rates during exercise when compared to an isoenergetic amount of glucose. Furthermore, we hypothesized that fructose provided as part of the disaccharide sucrose is less effective as the same amount of fructose provided as a monosaccharide to further augment exogenous carbohydrate oxidation rates during exercise. We tested our hypothesis by subjecting 10 male cyclists to a 180 min exercise bout on four occasions, during which they ingested GLU (1.8 $\mathrm{g} \cdot \mathrm{min}^{-1}$ glucose), GLU+FRU (1.2 $\mathrm{g} \cdot \mathrm{min}^{-1}$ glucose $+0.6 \mathrm{~g} \cdot \mathrm{min}^{-1}$ fructose), GLU+SUC (0.6 $\mathrm{g} \cdot \mathrm{min}^{-}$ ${ }^{1}$ glucose $+1.2 \mathrm{~g} \cdot \mathrm{min}^{-1}$ sucrose), or WAT (water placebo). 


\section{METHODS}

\section{Subjects}

Ten trained male cyclist or triathletes participated in this study (age: $26 \pm 1 \mathrm{y}$, body weight: $74.8 \pm 2.1 \mathrm{~kg}$, body mass index: $21.5 \pm 0.5 \mathrm{~kg} \cdot \mathrm{m}^{-2}$, maximal workload capacity (Wmax): $5.5 \pm 0.1 \mathrm{~W} \cdot \mathrm{kg}^{-1}$, peak oxygen consumption ( $\mathrm{VO}_{2}$ peak): $65 \pm 2 \mathrm{~mL} \cdot \mathrm{kg}^{-1} \cdot \mathrm{min}^{-1}$ ). Subjects cycled at least $100 \mathrm{~km} \cdot \mathrm{wk}^{-1}$ and had a training history of $>3 \mathrm{y}$. Subjects were fully informed on the nature and possible risks of the experimental procedures before their written informed consent was obtained. The study was approved by the Medical Ethical Committee of the Maastricht University Medical Centre, the Netherlands and conformed to standards for the use of human subjects in research outlined in the most recent version of the Helsinki Declaration. This trial was registered at clinicaltrials.gov as NCT0109617.

\section{Pretesting}

Baseline characteristics were determined during screening. Subject's maximal workload capacity $\left(\mathrm{W}_{\max }\right)$ and peak oxygen consumption ( $\mathrm{VO}_{2}$ peak) were determined while performing a stepwise exercise test to exhaustion on an electronically braked cycle (Lode Excalibur, Groningen, the Netherlands), using an online gas-collection system (Omnical, Maastricht University, The Netherlands). After a 5 min warm up at $100 \mathrm{~W}$, workload was set at $150 \mathrm{~W}$ and increased $50 \mathrm{~W}$ every $2.5 \mathrm{~min}$ until exhaustion. $\mathrm{VO}_{2}$ peak was defined as the median of the highest consecutive values over $30 \mathrm{~s}$. Maximal workload capacity was calculated as the workload in the last completed stage + workload relative to the time spent in the last incomplete stage: (time in seconds) $/ 150 * 50(\mathrm{~W})$.

\section{Diet and activity before testing}

Subjects recorded their food intake and activity pattern $2 \mathrm{~d}$ before the first experimental exercise trial and followed the same diet and exercise activities prior to the other three trials. In addition, 5-7 d before each experimental testing day, subjects performed an intense exercise training session to deplete $\left({ }^{13} \mathrm{C}\right.$-enriched) glycogen stores. Subjects were further instructed not to consume any food products with a high natural ${ }^{13} \mathrm{C}$ abundance (carbohydrates derived from $\mathrm{C} 4$ plants: maize, sugar cane) at least 1 week before and during the entire experimental period to minimize any shift in background ${ }^{13} \mathrm{CO}_{2}$ enrichment.

\section{Experimental design}

Each subject performed four exercise trials which consisted of 180 min of cycling at $50 \% \mathrm{~W}_{\text {max }}$ while ingesting a glucose drink (GLU), an isoenergetic glucose+fructose drink (GLU+FRU), an isoenergetic glucose+sucrose drink (GLU+SUC), or plain water (WAT). To quantify exogenous carbohydrate oxidation rates, corn-derived glucose monohydrate (Cargill, Sas van Gent, The Netherlands), crystalline fructose and sugar cane-derived sucrose (Rafti Sugar Solutions BV, Wijchen, The Netherlands) were used, all of which have a high natural ${ }^{13} \mathrm{C}$ abundance $(-11.2,-11.4$ and $-11.2 \delta \%$ vs Pee Dee Bellemnitella (PDB), respectively). The ${ }^{13} \mathrm{C}$ enrichment of the ingested glucose, fructose, and sucrose were determined by gas chromatography-combustion-isotope ratio mass spectrometry (GC/C/IRMS; Agilent 7890A /GC5975C; MSD, Wilmington, Delware, USA). To all drinks $20 \mathrm{mmol} \cdot \mathrm{L}^{-1}$ of sodium chloride was added. The order of the experimental drinks was randomly assigned in a cross-over double-blinded design. Experimental trials were separated by 7-28 $\mathrm{d}$. 


\section{Protocol}

Subjects reported to the laboratory in the morning at $0800 \mathrm{~h}$. after an overnight fast (10 h) and having refrained from any strenuous activity or drinking any alcohol in the previous $24 \mathrm{~h}$. On arrival in the laboratory, a Teflon catheter was inserted in an antecubital vein of an arm to allow repeated blood sampling during exercise. The subjects then mounted a cycle ergometer and a resting breath sample was collected in $10 \mathrm{~mL}$ Exetainer tubes (Labco Limited, Lampeter, United Kingdom), which were filled directly from a mixing chamber in duplicate to determine the ${ }^{13} \mathrm{C} /{ }^{12} \mathrm{C}$ ratio in the expired $\mathrm{CO}_{2}$. Next a resting blood sample $(10 \mathrm{~mL})$ was taken. Subjects then started a 180-min exercise bout at a work rate equivalent to 50\% Wmax. Blood samples were collected at 30-min intervals throughout the $180 \mathrm{~min}$ exercise period. Expired breath samples were collected every $15 \mathrm{~min}$ until cessation of exercise. Measurements of $\mathrm{VO}_{2}, \mathrm{VCO}_{2}$ and RER were obtained every 15 min for periods of 4 min through the use of a respiratory facemask, connected to an online gas-collection system [27].

During the first 3 min of exercise, subjects drank an initial bolus $(600 \mathrm{~mL})$ of one of the four experimental drinks: GLU, GLU+FRU, GLU+SUC, or WAT. Thereafter, every 15 min a beverage volume of a $150 \mathrm{~mL}$ was provided. The total fluid provided during the 180 min-exercise bout was $2.25 \mathrm{~L}$. The GLU, $\mathrm{GLU}+\mathrm{FRU}$, and GLU+SUC drinks provided $1.8 \mathrm{~g}$ carbohydrate $\cdot \mathrm{min}^{-1}$. The GLU drink provided $1.8 \mathrm{~g} \cdot \mathrm{min}^{-}$ ${ }^{1}$ glucose, the GLU+FRU drink provided $1.2 \mathrm{~g} \cdot \mathrm{min}^{-1}$ glucose $+0.6 \mathrm{~g} \cdot \mathrm{min}^{-1}$ fructose, and the GLU+SUC drink provided $0.6 \mathrm{~g} \cdot \mathrm{min}^{-1}$ glucose $+1.14 \mathrm{~g} \cdot \mathrm{min}^{-1}$ sucrose. The amount of sucrose $\left(1.14 \mathrm{vs} 1.2 \mathrm{~g} \cdot \mathrm{min}^{-1}\right)$ was selected to allow exactly the same equimolar amounts of glucose and fructose provided in the GLU+SUC, GLU and GLU+FRU drinks.

Subjects were asked to rate their perceived exertion (RPE) every 30 min on a scale from 6 to 20 using the Borg category scale [28]. In addition, subjects were asked every $30 \mathrm{~min}$ to fill in questionnaire to rate possible gastrointestinal (Gl) problems using a ten-point scale ( $1=$ no complaints at all, $10=$ very severe complaints). The questions consisted of six questions related to upper Gl symptoms (nausea, general stomach problems, belching, urge to vomit, heartburn, and stomach cramps), four questions related to lower Gl complaints (flatulence, urge to defecate, intestinal cramps, and diarrhea), and four questions related to central or other symptoms (dizziness, headache, urge to urinate, and bloated feeling). All exercise tests were performed under normal and standard environmental conditions (1822 degree $C$ dry bulb temperature and $55-65 \%$ relative humidity). During the exercise trials, subjects were cooled with standing floor fans.

\section{Analyses}

Blood samples $(10 \mathrm{~mL})$ were collected in EDTA-containing tubes and centrifuged at $1000 \mathrm{~g}$ and $4^{\circ} \mathrm{C}$ for $10 \mathrm{~min}$. Aliquots of plasma were frozen in liquid nitrogen and stored at $-80^{\circ} \mathrm{C}$ until analysis. Plasma glucose and lactate were analyzed with a COBAS FARA semiautomatic analyzer (Roche). Plasma insulin concentrations were analyzed using commercially available kits (Elecsys Insulin assay, Roche, Ref: 12017547122). Plasma I-FABP levels were measured using an in-house developed enzyme-linked immunosorbent assay. The detection window of the I-FABP assay is $12.5-800 \mathrm{pg} \cdot \mathrm{mL}^{-1}$, with an intraassay and inter-assay coefficient of variation of 4.1 and $6.2 \%$, respectively $[23,29]$. Breath samples were analyzed for ${ }^{13} \mathrm{C} /{ }^{12} \mathrm{C}$ ratio by gas chromatography continuous flow isotope ratio mass spectrometry (GC/C/IRMS; Finnigan, Bremen, Germany). From indirect calorimetry $\left(\mathrm{VO}_{2}\right.$ and $\left.\mathrm{VCO}_{2}\right)$ and stable isotope measurements (breath ${ }^{13} \mathrm{CO}_{2} /{ }^{12} \mathrm{CO}_{2}$ ratio), oxidation rates of total fat, total carbohydrate and exogenous carbohydrate were calculated. 


\section{Calculations}

From $\mathrm{VCO}_{2}$ and $\mathrm{VO}_{2}\left(\mathrm{~L} \cdot \mathrm{min}^{-1}\right)$, total carbohydrate and fat oxidation rates $\left(\mathrm{g} \cdot \mathrm{min}^{-1}\right)$ were calculated using stoichiometric equations of Frayn [30] with the assumption that protein oxidation during exercise was negligible:

$$
\begin{aligned}
& \text { Carbohydrate oxidation }=4.55 \mathrm{VCO}_{2}-3.21 \mathrm{VO}_{2} \\
& \text { Fat oxidation }=1.67 \mathrm{VO}_{2}-1.67 \mathrm{VCO}_{2}
\end{aligned}
$$

The isotopic enrichment was expressed as $\delta$ per mil difference between the ${ }^{13} \mathrm{C} /{ }^{12} \mathrm{C}$ ratio of the sample and a known laboratory reference standard according to the formula of Craig [31]:

$$
\delta^{13} \mathrm{C}=\left(\left(\frac{{ }^{13} \mathrm{C} /{ }^{12} \mathrm{C} \text { sample }}{{ }^{13} \mathrm{C} /{ }^{12} \mathrm{C} \text { standard }}\right)-1\right) \cdot 10^{3}
$$

The $\delta^{13} \mathrm{C}$ was then related to an international standard (PDB-1). In the GLU, GLU+FRU, and GLU+SUC treatments, the rate of exogenous carbohydrate oxidation was calculated using the following [32]:

$$
\text { Exogenous glucose oxidation }=\mathrm{VCO}_{2} \cdot\left(\frac{\delta \text { Exp }-\delta \operatorname{Exp}_{\mathrm{bkg}}}{\delta \operatorname{Ing}-\delta \operatorname{Exp}_{\mathrm{bkg}}}\right)\left(\frac{1}{\mathrm{k}}\right)
$$

in which $\delta$ Exp is the ${ }^{13} \mathrm{C}$ enrichment of expired air during exercise at different time points, $\delta$ Ing is the ${ }^{13} \mathrm{C}$ enrichment of the ingested carbohydrate solution, $\delta$ Expbkg is the ${ }^{13} \mathrm{C}$ enrichment of expired air in the WAT treatment (background) at different time points and $k$ is the amount of $\mathrm{CO}_{2}$ (in L) produced by the oxidation of $1 \mathrm{~g}$ of glucose $\left(k=0.7467 \mathrm{~L}\right.$ of $\mathrm{CO}_{2} \cdot \mathrm{g}^{-1}$ of glucose).

A methodological consideration when using ${ }^{13} \mathrm{CO}_{2}$ in expired air to calculate exogenous substrate oxidation is the trapping of ${ }^{13} \mathrm{CO}_{2}$ in the bicarbonate pool, in which an amount of $\mathrm{CO}_{2}$ arising from decarboxylation of energy substrates is temporarily trapped [33]. However, during exercise the $\mathrm{CO}_{2}$ production increases several-fold so that a physiological steady state condition will occur relatively rapidly, and ${ }^{13} \mathrm{CO}_{2}$ in the expired air will be equilibrated with the ${ }^{13} \mathrm{CO}_{2} / \mathrm{H}^{13} \mathrm{CO}_{3}^{-}$pool, respectively. Recovery of the ${ }^{13} \mathrm{CO}_{2}$ from oxidation will approach $100 \%$ after 60 min of exercise when dilution in the bicarbonate pool becomes negligible [33,34]. As a consequence of this, calculations on substrate oxidation were performed over the last $120 \mathrm{~min}$ of exercise (60-180 min).

\section{Statistical analyses}

Plasma and substrate utilization parameters are expressed as means \pm SEM, RPE and GI distress scores are expressed as median and interquartile range. A sample size of 10 was calculated with a power of $80 \%$ and an alpha level of 0.05 to detect a $\sim 20 \%$ difference in exogenous carbohydrate oxidation between treatments [20]. For all data, the normality of the distribution was confirmed after visual inspection and the use of Shapiro-Wilk tests. A one-way repeated measures ANOVA with treatment as factor was used to compare differences in substrate utilization parameters between treatments. In case of significant F-ratios, Bonferroni post-hoc tests were applied to locate the differences. A two-way repeated measures ANOVA with time and treatment as factors was used to compare differences in plasma parameters between treatments and over time. In case of significant F-ratios, paired t-tests were used to locate the differences. A Friedman test was performed to compare RPE and GI distress scores between treatments. In case of significant $\mathbf{X}$, post hoc analysis with Wilcoxon signed-rank test was conducted. Data evaluation was performed using SPSS (version 21.0, IBM Corp., Armonk, NY, USA). Statistical significance was set at $P<0.05$. 


\section{RESULTS}

\section{Indirect calorimetry}

Data for $\mathrm{VO}_{2}, \mathrm{RER}$, and total carbohydrate and fat oxidation rates over the 60 to $180 \mathrm{~min}$ exercise period are presented in Table 2.1. $\mathrm{VO}_{2}$ did not differ between the 4 experimental treatments $(P=0.301)$. RER in WAT was lower compared with GLU+FRU and GLU+SUC $(P<0.05)$. Total carbohydrate oxidation rates were lower in the WAT compared with GLU+FRU and GLU+SUC treatments $(P<0.05)$. No significant differences in total carbohydrate oxidation rates were observed between GLU, GLU+FRU and GLU+SUC (pairwise comparisons: all $P \geq 0.172$ ). Total fat oxidation rates were higher in WAT compared to $G L U+S U C(P=0.010)$. No significant differences in total fat oxidation rates were observed between GLU, GLU+FRU and GLU+SUC (pairwise comparisons: all $P \geq 0.443$ ).

Table 2.1. Oxygen uptake $\left(\mathrm{VO}_{2}\right)$, respiratory exchange ratio (RER), total carbohydrate $(\mathrm{CHO})$ oxidation $(\mathrm{CHOtot})$, total fat oxidation (FATtot), endogenous carbohydrate (Endogenous $\mathrm{CHO}$ ), and exogenous carbohydrate (Exogenous $\mathrm{CHO}$ ) oxidation during cycling exercise with ingestion of GLU, GLU+FRU, and GLU+SUC, and WAT.

\begin{tabular}{|c|c|c|c|c|c|c|c|c|}
\hline & Time & $\begin{array}{c}\text { VO2 } \\
\left(L \cdot \min ^{-1}\right)\end{array}$ & RER & $\begin{array}{l}\text { CHOtot } \\
\left(g \cdot \min ^{-1}\right)\end{array}$ & $\begin{array}{l}\text { FATtot } \\
\left(g \cdot \min ^{-1}\right)\end{array}$ & $\begin{array}{c}\text { Endogenous } \\
\text { CHO } \\
\left(\mathrm{g} \cdot \mathrm{min}^{-1}\right)\end{array}$ & $\begin{array}{c}\text { Exogenous } \\
\text { CHO } \\
\left(g \cdot \mathrm{min}^{-1}\right)\end{array}$ & $\begin{array}{c}\text { Peak } \\
\text { Exogenous } \\
\text { CHO } \\
\left(\mathrm{g} \cdot \mathrm{min}^{-1}\right)\end{array}$ \\
\hline \multirow{4}{*}{ WAT } & $60-90$ & $2.94 \pm 0.06$ & $0.81 \pm 0.01$ & $1.35 \pm 0.18$ & $0.95 \pm 0.09$ & $1.35 \pm 0.18$ & & \\
\hline & $90-120$ & $2.96 \pm 0.06$ & $0.80 \pm 0.01$ & $1.19 \pm 0.19$ & $1.02 \pm 0.09$ & $1.19 \pm 0.19$ & & \\
\hline & $120-150$ & $3.00 \pm 0.06$ & $0.79 \pm 0.04$ & $1.07 \pm 0.18$ & $1.08 \pm 0.09$ & $1.07 \pm 0.18$ & & \\
\hline & $150-180$ & $3.04 \pm 0.06$ & $0.78 \pm 0.05$ & $1.01 \pm 0.60$ & $1.12 \pm 0.09$ & $1.01 \pm 0.19$ & & \\
\hline \multirow{4}{*}{ GLU } & $60-90$ & $2.96 \pm 0.06$ & $0.83 \pm 0.01$ & $1.63 \pm 0.15$ & $0.86 \pm 0.07$ & $0.91 \pm 0.13$ & $0.72 \pm 0.05$ & \\
\hline & $90-120$ & $2.99 \pm 0.06$ & $0.83 \pm 0.01$ & $1.65 \pm 0.15$ & $0.86 \pm 0.07$ & $0.82 \pm 0.12$ & $0.83 \pm 0.06$ & $0.96 \pm 0.06$ \\
\hline & $120-150$ & $2.97 \pm 0.06$ & $0.82 \pm 0.01$ & $1.58 \pm 0.14$ & $0.88 \pm 0.07$ & $0.72 \pm 0.10$ & $0.85 \pm 0.06$ & \\
\hline & $150-180$ & $3.00 \pm 0.06$ & $0.82 \pm 0.01$ & $1.55 \pm 0.14$ & $0.90 \pm 0.07$ & $0.65 \pm 0.11$ & $0.89 \pm 0.06$ & \\
\hline \multirow{4}{*}{$\begin{array}{c}\text { GLU } \\
+ \\
\text { FRU }\end{array}$} & $60-90$ & $3.00 \pm 0.06$ & $0.85 \pm 0.01$ & $1.96 \pm 0.10$ & $0.76 \pm 0.04$ & $0.93 \pm 0.11$ & $1.03 \pm 0.04^{b}$ & \\
\hline & $90-120$ & $3.01 \pm 0.05$ & $0.85 \pm 0.01$ & $1.94 \pm 0.12$ & $0.77 \pm 0.05$ & $0.76 \pm 0.12$ & $1.18 \pm 0.04^{b}$ & $1.40 \pm 0.06$ \\
\hline & $120-150$ & $3.05 \pm 0.05$ & $0.84 \pm 0.01^{a}$ & $1.87 \pm 0.12^{\mathrm{a}}$ & $0.81 \pm 0.04$ & $0.61 \pm 0.11$ & $1.25 \pm 0.04^{b}$ & \\
\hline & $150-180$ & $3.12 \pm 0.06$ & $0.84 \pm 0.01^{a}$ & $1.96 \pm 0.15^{a}$ & $0.80 \pm 0.05^{a}$ & $0.63 \pm 0.14$ & $1.33 \pm 0.05^{b}$ & \\
\hline \multirow{4}{*}{$\begin{array}{c}\text { GLU } \\
+ \\
\text { SUC }\end{array}$} & $60-90$ & $2.90 \pm 0.08$ & $0.87 \pm 0.02^{\mathrm{a}}$ & $2.08 \pm 0.18^{a}$ & $0.67 \pm 0.09^{a}$ & $1.09 \pm 0.17$ & $0.98 \pm 0.06^{b}$ & \\
\hline & $90-120$ & $2.95 \pm 0.08$ & $0.85 \pm 0.01^{a}$ & $1.95 \pm 0.15^{a}$ & $0.73 \pm 0.08^{a}$ & $0.85 \pm 0.14$ & $1.10 \pm 0.07^{b}$ & $1.29 \pm 0.07$ \\
\hline & $120-150$ & $2.98 \pm 0.08$ & $0.85 \pm 0.01^{a}$ & $1.91 \pm 0.14^{\mathrm{a}}$ & $0.77 \pm 0.07^{a}$ & $0.72 \pm 0.12$ & $1.19 \pm 0.07^{b}$ & \\
\hline & $150-180$ & $3.00 \pm 0.08$ & $0.85 \pm 0.01^{a}$ & $1.93 \pm 0.15^{a}$ & $0.77 \pm 0.07^{a}$ & $0.68 \pm 0.12$ & $1.25 \pm 0.07^{b}$ & \\
\hline
\end{tabular}

WAT: ingestion of water only; GLU: ingestion of glucose; GLU+FRU: ingestion of glucose and fructose; GLU+SUC: ingestion of glucose and sucrose. Data are presented as means $\pm \mathrm{SE} . \mathrm{N}=10$. ${ }^{a}$, denotes significantly different from WAT; ${ }^{b}$, denotes significantly different from GLU $(P<0.05)$.

\section{Stable-isotope measurements}

Changes in isotopic composition of expired $\mathrm{CO}_{2}$ in response to exercise with ingestion of GLU, GLU+FRU, GLU+SUC or WAT are presented in Figure 2.1A. Resting breath ${ }^{13} \mathrm{CO}_{2}$ enrichments did not differ between treatments, and averaged $-26.55 \pm 0.13,-26.86 \pm 0.16,-26.69 \pm 0.14,-26.83 \pm 0.18 \delta \%$ 。 versus PDB for WAT, GLU, GLU+FRU, and GLU+SUC, respectively. No significant increases in expired breath ${ }^{13} \mathrm{CO}_{2}$ enrichments were observed in the water only treatment (WAT; $P=0.096$ ). In contrast, expired breath ${ }^{13} \mathrm{CO}_{2}$ enrichments strongly increased to up to $-22.36 \pm 0.33,-20.70 \pm 0.18$, and $20.97 \pm 0.34 \delta \%$ versus PDB in the GLU, GLU+FRU, and GLU+SUC treatments, respectively (time $x$ treatment, $P<0.001$ ). The slight shift in expired breath ${ }^{13} \mathrm{CO}_{2}$ enrichments in the WAT treatment was used as a background correction for the calculation of exogenous carbohydrate oxidation rates in the GLU, GLU+FRU and GLU+SUC treatments. 


\section{Exogenous and endogenous carbohydrate oxidation rates}

In the GLU, GLU+FRU, and GLU+SUC treatments, the calculated exogenous carbohydrate oxidation rates increased significantly over time (Figure 2.1B, $P<0.001$ ). Peak exogenous carbohydrate oxidation rates were $51 \pm 9 \%$ and $40 \pm 12 \%$ higher in GLU+FRU and GLU+SUC when compared to GLU $(1.40 \pm 0.06$ and $1.29 \pm 0.07$ vs $0.96 \pm 0.06 \mathrm{~g} \cdot \mathrm{min}^{-1}$, respectively: $P<0.05$ ). Peak exogenous carbohydrate oxidation rates did not differ between GLU+FRU and GLU+SUC ( $P=0.999)$. Assessed over the last 120 min of exercise, average exogenous carbohydrate oxidation rates were higher in the GLU+FRU and GLU+SUC treatments compared to the GLU treatments $\left(1.19 \pm 0.12,1.13 \pm 0.21\right.$, and $0.82 \pm 0.16 \mathrm{~g} \cdot \mathrm{min}^{-1}$, respectively: $P<0.05)$. No differences were observed in exogenous carbohydrate oxidation rates between GLU+FRU and GLU+SUC ( $P=0.999)$. No significant differences in endogenous carbohydrate oxidation rates were observed between treatments $(P=0.112)$. The relative contribution of substrates to total energy expenditure during exercise is presented in Figure 2.2.
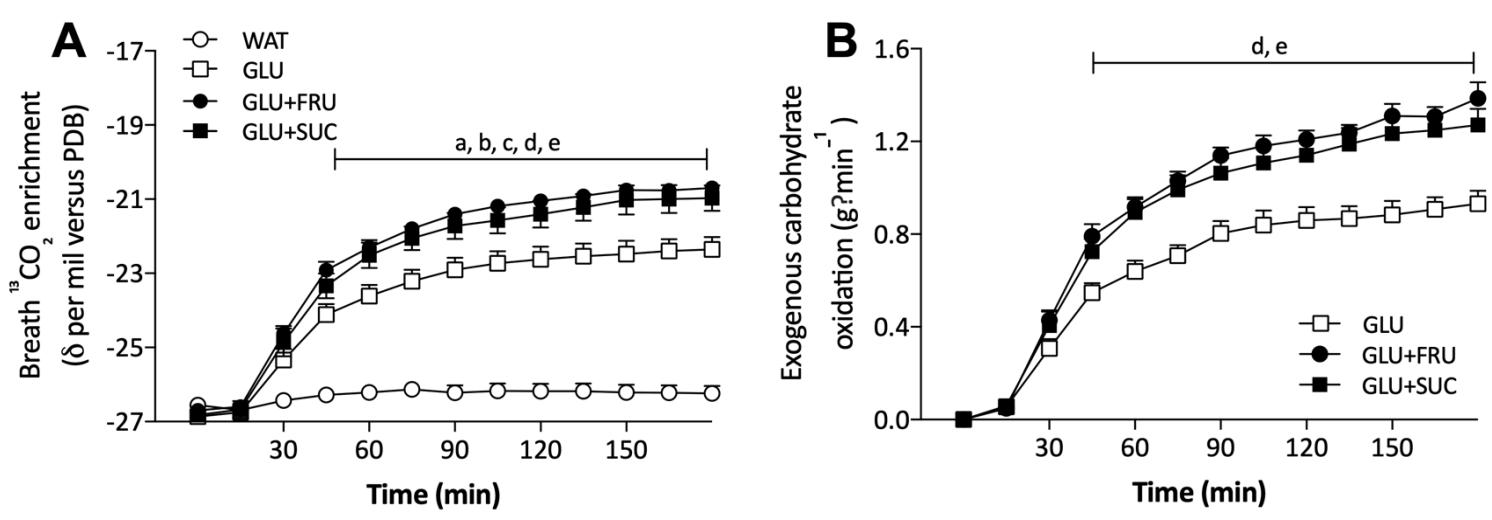

Figure 2.1. Breath ${ }^{13} \mathrm{CO}_{2}$ enrichments $(A)$ and exogenous carbohydrate oxidation rates (B) during exercise without ingestion of carbohydrate (WAT), with the ingestion of glucose (GLU), with the ingestion of glucose and fructose (GLU+FRU), or with the ingestion of glucose and sucrose (GLU+SUC). Data were analsysed with a two-way repeated measures ANOVA (time-treatment). Data are presented as means \pm SEM. $N=10$. a, denotes GLU significantly different from WAT; $b$, denotes GLU+FRU significantly different from WAT; $c$, denotes GLU+SUC significantly different from WAT; d, denotes GLU+FRU significantly different from GLU; e, denotes GLU+SUC significantly different from GLU $(P<0.05)$. 


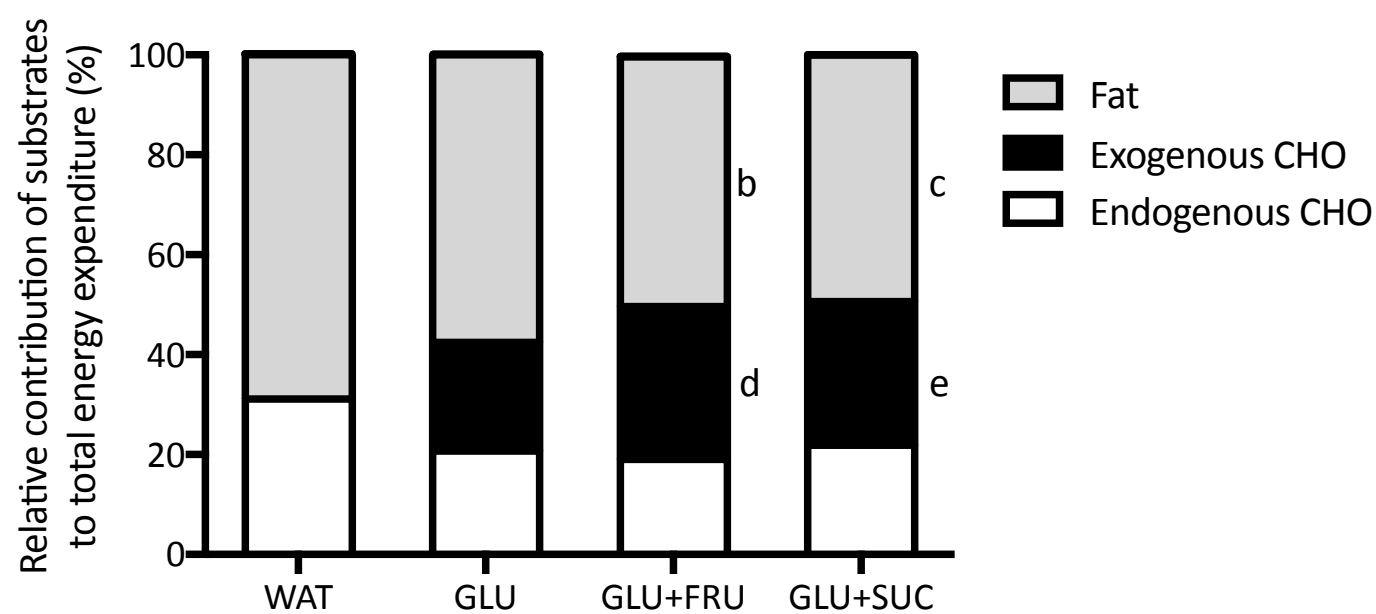

Figure 2.2. Relative contribution of substrates to total energy expenditure calculated for the 60 - to 180 min period of exercise without the ingestion of carbohydrate (WAT), with the ingestion of glucose (GLU), with the ingestion of glucose and fructose $(G L U+F R U)$, or with the ingestion of glucose and sucrose (GLU+SUC). Data were analsysed with a repeated measures ANOVA (treatment). Data are presented as means \pm SEM. $N=10 . b$, denotes GLU+FRU significantly different from WAT; $c$, denotes GLU+SUC significantly different from WAT; d, denotes GLU+FRU significantly different from GLU; e, denotes GLU+SUC significantly different from GLU $(P<0.05)$.

\section{Plasma metabolites}

Plasma glucose, insulin, and lactate concentrations are shown in Figure 2.3. Plasma glucose concentrations showed a transient increase at $t=30 \mathrm{~min}$ in the GLU, GLU+FRU and GLU+SUC treatments, but plasma glucose concentrations at $t=30$ min were only significantly higher in GLU+SUC compared to WAT $(P=0.028)$. Plasma glucose concentrations decreased in the WAT treatment compared to the GLU, GLU+FRU and GLU+SUC treatments (time $x$ treatment interaction: $P<0.001$ ). Plasma glucose concentrations were significantly lower in the WAT treatment compared to the GLU, $\mathrm{GLU}+\mathrm{FRU}$ and $\mathrm{GLU}+\mathrm{SUC}$ treatments from $\mathrm{t}=90 \mathrm{~min}$ onwards $(P<0.05)$. Plasma insulin concentrations increased in the GLU, GLU+FRU and GLU+SUC treatments, peaking at $\mathrm{t}=30$ after glucose ingestion $\left(8.2 \pm 1.2,8.3 \pm 1.1\right.$, and $10.6 \pm 2.2 \mathrm{mU} \cdot \mathrm{L}^{-1}$, respectively), and then declined throughout exercise. In contrast, plasma insulin concentrations declined throughout the entire exercise bout in the WAT treatment (time $\mathrm{x}$ treatment interaction: $P<0.001$ ).

Plasma lactate concentrations increased in all treatments, but this increase was much greater in the GLU+FRU and GLU+SUC treatments when compared with the WAT and GLU treatments (time $x$ treatment interaction: $P<0.001$ ). Plasma I-FABP levels, depicted as a percentage change from individual baseline values, did not change significantly over time ( $P=0.764$; Figure 2.4A). AUC calculations of the percentage change from individual I-FABP baseline values did not differ between treatments $(P=0.101$; Figure 2.4B).

\section{Gastrointestinal distress and rating of percieved exertion}

Total upper GI distress scores were 62 (53-83), 109 (67-147), 69 (57-96) and 74 (53-79), in the WAT, GLU, GLU+FRU, GLU+SUC treatments, respectively, and were significantly higher in the GLU compared to the WAT, GLU+FRU, and GLU+SUC treatments $(P<0.05)$. Low GI distress scores were observed for other symptons, with the exception of urge to urinate which did not differ between treatments $(P=0.455)$. Ratings of perceived exertion did not differ between treatments and averaged 13 (11-14), 14 (13-14), 13 (12-13), and 13 (12-14) for WAT, GLU, GLU+FRU, and GLU+SUC, respectively $(P=0.056)$. 


\section{DISCUSSION}

The present study shows that the combined ingestion of glucose and fructose $\left(1.2 \mathrm{~g} \cdot \mathrm{min}^{-1}\right.$ glucose plus $0.6 \mathrm{~g} \cdot \mathrm{kg}^{-1}$ fructose or $0.6 \mathrm{~g} \cdot \mathrm{min}^{-1}$ glucose plus $1.2 \mathrm{~g} \cdot \mathrm{min}^{-1}$ sucrose) further increases exogenous carbohydrate oxidation rates compared to the ingestion of an isocaloric amount of glucose only. Furthermore, combined ingestion of glucose plus fructose or sucrose resulted in less GI complaints when compared with the ingestion of glucose only.

Previous work suggests that exogenous glucose oxidation rates are limited by intestinal glucose absorption [5,7]. Because fructose is absorbed through a different intestinal transport route, higher total intestinal carbohydrate absorption rates can be expected when glucose and fructose are coingested. Therefore, we hypothesized that fructose co-ingestion with glucose would increase total carbohydrate oxidation rates during prolonged exercise. Furthermore, we hypothesized that fructose provided as part of the disaccharide sucrose is less effective as the same amount of fructose provided as a monosaccharide to further augment exogenous glucose oxidation rates during exercise.
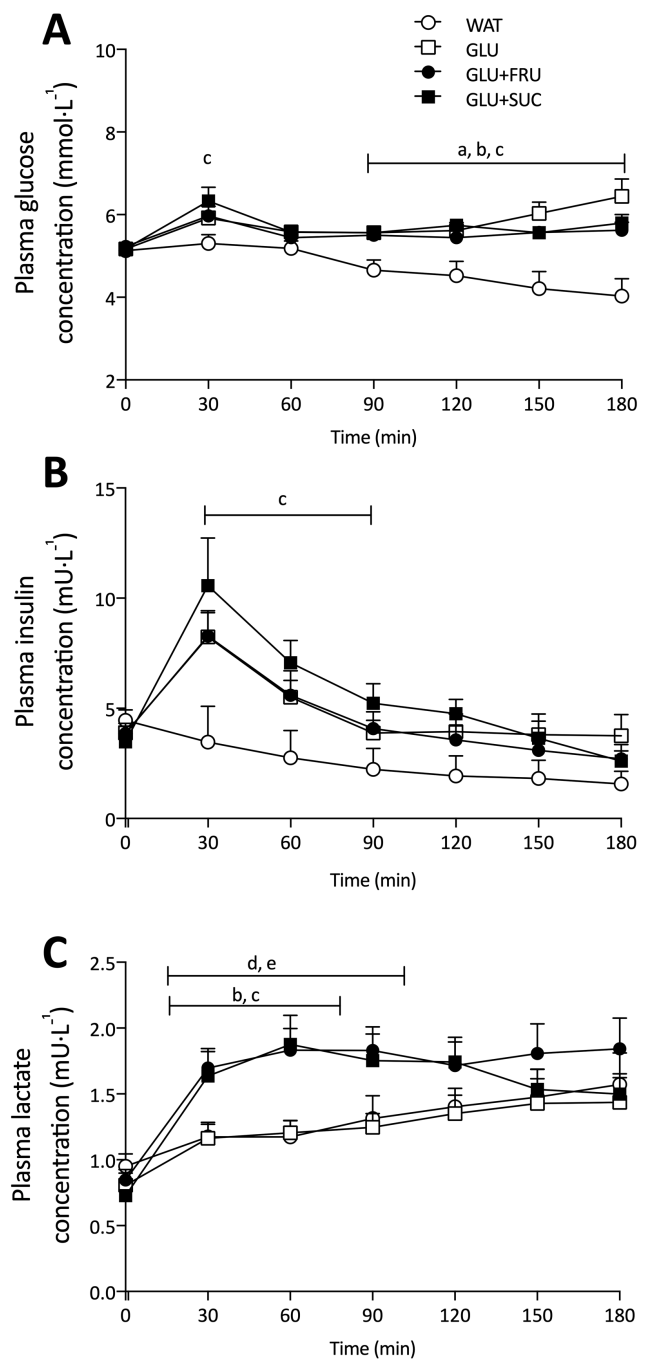

Figure 2.3. Plasma glucose (A), insulin (B), and lactate (C) concentrations during exercise without ingestion of carbohydrate (WAT), with the ingestion of glucose (GLU), with the ingestion of glucose and fructose (GLU+FRU), or with the ingestion of glucose and sucrose (GLU+SUC). Data were analsysed with a two-way repeated measures ANOVA (time-treatment). Data are presented as means \pm SEM. $N=10$. a, denotes GLU significantly different from WAT; $b$, denotes GLU+FRU significantly different from WAT; $c$, denotes GLU+SUC significantly different from WAT; d, denotes GLU+FRU significantly different from GLU; e, denotes GLU+SUC significantly different from GLU $(P<0.05)$. 

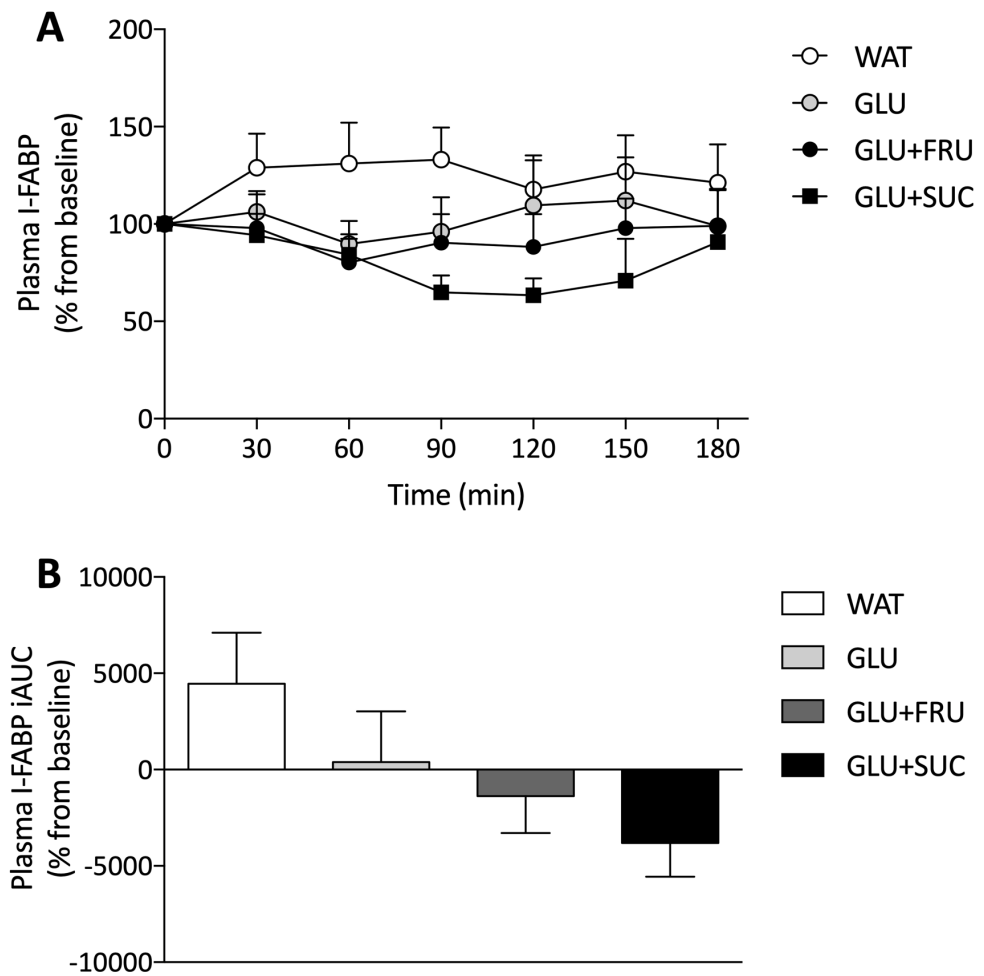

Figure 2.4. Plasma I-FABP concentrations during exercise (A) and AUC of percentage I-FABP change during exercise (B) without ingestion of carbohydrate (WAT), with the ingestion of glucose (GLU), with the ingestion of glucose and fructose (GLU+FRU), or with the ingestion of glucose and sucrose (GLU+SUC). Plasma I-FABP (A) was analsysed with a two-way repeated measures ANOVA (time-treatment). Plasma I-FABP iAUC was analysed with a repeated measures ANOVA (treatment). Data are presented as means \pm SEM. $N=10$. Differences between treatments did not reach statistical significance $(P>0.05)$.

In the present study, we observed that the ingestion of an ample amount of glucose only results in peak exogenous carbohydrate oxidation rates of $0.96 \pm 0.06 \mathrm{~g} \cdot \mathrm{min}^{-1}$ (Figure 2.1). These rates are in line with previous work and confirm that exogenous glucose oxidation rates will not rise above 1.0-1.1 $\mathrm{g} \cdot \mathrm{min}^{-1}$ when only glucose is ingested during exercise $[7,16,22,35,36]$. Combined ingestion of glucose plus fructose or glucose plus sucrose in the present study resulted in peak exogenous carbohydrate oxidation rates of $1.40 \pm 0.06$ and $1.29 \pm 0.07 \mathrm{~g} \cdot \mathrm{min}^{-1}$, respectively (Figure 2.1). These data confirm previous observations showing $35-55 \%$ higher exogenous carbohydrate oxidation rates following fructose co-ingestion when compared to the ingestion of glucose only during exercise $[8,16]$. While sucrose co-ingestion has also been shown to increase exogenous carbohydrate oxidation rates $[19,20]$, maximal exogenous carbohydrate oxidation rates appear lower when sucrose $[19,20]$ as opposed to fructose $[8,16,21,22]$ is co-ingested during exercise $\left(1.2-1.3\right.$ vs $1.3-1.8 \mathrm{~g} \cdot \mathrm{min}^{-1}$, respectively). In the present study, we compared the impact of equimolar amounts of fructose co-ingestion provided as its monosaccharide or provided as sucrose on exogenous carbohydrate oxidation rates during exercise in the same cohort of athletes. We extend on previous work by showing no significant differences in peak exogenous carbohydrate oxidation rates between the GLU+FRU and GLU+SUC treatments $(P=0.999)$. These results suggest that sucrose intestinal digestion and/or absorption are not rate limiting for subsequent oxidation. Consequently, we demonstrate that fructose co-ingestion provided as part of the disaccharide sucrose does not differ from an equivalent amount of fructose provided as monosaccharide to augment exogenous carbohydrate oxidation rates during endurance type exercise. 
The ingestion of glucose only resulted in substantial higher $\mathrm{Gl}$ distress when compared to the WAT, GLU+FRU and GLU+SUC treatments $(P<0.05)$. The lower total $G I$ distress with fructose or sucrose coingestion seems to suggest that these treatments result in less carbohydrate accumulation in the $\mathrm{Gl}$ tract, possibly caused by more rapid intestinal carbohydrate absorption when compared with the ingestion of glucose only [37]. To further evaluate potential underlying mechanisms of the GI discomfort, we also measured plasma I-FAPB as a marker of intestinal damage. Previous work has shown that exercise resulted in a rapid appearance of this marker in blood, which correlated with splanchnic hypoperfusion [23]. Though not significant, we observed lower I-FABP release in the GLU, GLU+FRU, and GLU+SUC groups compared with the WAT treatment $(P=0.101$, Figure 2.4). The observed increase in plasma I-FABP in the WAT treatment was lower when compared to our previous work [29]. This may be explained by differences in the exercise protocols. In our previous work, subjects cycled for $60 \mathrm{~min}$ at $70 \% \mathrm{Wmax}$ vs $180 \mathrm{~min}$ at $50 \% \mathrm{Wmax}$ in the current study. This suggests that exercise intensity may be a more important modulator of peak plasma I-FABP levels than exercise duration. It remains to be established whether carbohydrate ingestion may reduce exercise-induced GI compromise during higher intensity exercise.

After ingestion and intestinal absorption, fructose is metabolized in the liver and subsequently released in the systemic circulation as lactate or converted to glucose via gluconeogenesis, which is mainly released or used for liver glycogen synthesis depending on the need to maintain plasma glucose levels [38]. We observed no significant differences in plasma glucose concentrations between the GLU, $\mathrm{GLU}+\mathrm{FRU}$, and the GLU+SUC treatments (Figure 2.3). We have recently shown that sucrose ingestion does not preserve liver glycogen concentrations more than glucose ingestion during exercise [39]. Therefore, it seems unlikely that hepatic glycogenesis was a major fate of the ingested fructose during exercise. We did observe elevated plasma lactate concentrations in the GLU+FRU and GLU+SUC treatments when compared to the GLU treatment. Fructose co-ingestion has been shown to increase plasma lactate production and oxidation, with a minimal amount of fructose being directly oxidized [40]. Therefore, fructose or sucrose co-ingested with glucose appears to be effectively absorbed in the intestine and transported to the liver where it is metabolized to lactate, released in the circulation and subsequently oxidized.

Exogenous glucose oxidation rates have been shown to correlate with exercise performance during prolonged, moderate- to high-intensity exercise [2]. Fructose co-ingestion further improves exogenous carbohydrate oxidation rates and has shown to improve exercise performance compared to an isocaloric amount of glucose $[8,14,16,22,41-43]$. The latter has been attributed to a combination of higher exogenous carbohydrate oxidation rates and decreased Gl distress $[41,43]$. Although we did not assess exercise performance, we observed increased exogenous carbohydrate rates and lower $\mathrm{GI}$ distress following fructose co-ingestion. Furthermore, exogenous carbohydrate oxidation rates and GI distress levels did not differ between the GLU+FRU and GLU+SUC treatments. Therefore, our data suggest that both fructose and sucrose represents proper ingredients for sports drinks to further increase exogenous carbohydrate oxidation rates during exercise.

This study presents several limitations. First, we assessed whole-body exogenous carbohydrate oxidation rates following fructose co-ingestion, which does not provide insight in the specific site of oxidation. The increased exogenous carbohydrate oxidation rates following fructose co-ingestion is 
likely largely attributed to increased lactate oxidation in muscle $[40,44]$. However, hepatic fructose conversion into glucose and/or lactate costs energy [45], thereby decreasing energy efficiency and possibly increasing hepatic carbohydrate oxidation rates. Therefore, the observed $46 \pm 8 \%$ higher exogenous carbohydrate oxidation rates following fructose co-ingestion may slightly overestimate increased energy availability and exogenous carbohydrate oxidation rates in muscle. Secondly, we cannot exclude the possibility that sucrose co-ingestion is less effective at increasing exogenous carbohydrate oxidation when compared to fructose monosaccharide co-ingestion when total carbohydrate ingestion rates are higher than provided in the current study. It has been suggested that sucrose digestion and/or absorption becomes a limiting factor to further increase exogenous carbohydrate oxidation rates when total carbohydrate intakes levels exceed $1.8 \mathrm{~g} \cdot \mathrm{min}^{-1}$ [19]. However, such carbohydrate ingestion rates may be impractically high and result in $\mathrm{Gl}$ distress that may be detrimental to exercise performance [43]. Therefore, we provided total carbohydrate ingestion rates that are more practical and have shown to increase performance [42].

We conclude that fructose co-ingestion provided either as monosaccharide or as sucrose strongly increases exogenous carbohydrate oxidation rates during prolonged exercise in trained cyclists. When ingesting large amounts of carbohydrate during exercise, co-ingestion of fructose or sucrose will lower GI distress and increase the capacity for exogenous carbohydrate oxidation.

\section{ACKNOWLEDGMENTS}

We gratefully acknowledge the assistance of Janneau van Kranenburg and the enthusiastic support of the volunteers who participated in these experiments. This project was partly funded by a research grant from Kenniscentrum Suiker \& Voeding, Utrecht, the Netherlands and Sugar Nutrition UK, London, United Kingdom.

\section{AUTHOR CONTRIBUTIONS}

A.E.J., N.M.C., and L.v.L. conceived and designed the experiments; J.T. and C.J.F. performed the experiments; J.T. and K.L. analyzed the data; K.L. contributed reagents/materials/analysis tools; J.T., M.B. and L.v.L wrote the paper.

\section{CONFLICTS OF INTEREST}

The authors declare no conflict of interest. The founding sponsors had no role in the design of the study; in the collection, analyses, or interpretation of data; in the writing of the manuscript, and in the decision to publish the results. 


\section{REFERENCES}

1. Coyle EF, Coggan AR, Hemmert MK, Ivy JL. Muscle glycogen utilization during prolonged strenuous exercise when fed carbohydrate. J Appl Physiol (1985). 1986;61:165-72.

2. Smith JW, Zachwieja JJ, Peronnet F, Passe DH, Massicotte D, Lavoie C, et al. Fuel selection and cycling endurance performance with ingestion of [13C]glucose: evidence for a carbohydrate dose response. J Appl Physiol (1985). 2010;108:1520-9.

3. Stellingwerff T, Cox GR. Systematic review: Carbohydrate supplementation on exercise performance or capacity of varying durations. Appl. Physiol. Nutr. Metab. 2014;39:998-1011.

4. Coggan AR, Coyle EF. Reversal of fatigue during prolonged exercise by carbohydrate infusion or ingestion. J Appl Physiol (1985). 1987;63:2388-95.

5. Jeukendrup AE, Wagenmakers AJ, Stegen JH, Gijsen AP, Brouns F, Saris WH. Carbohydrate ingestion can completely suppress endogenous glucose production during exercise. Am J Physiol. 1999;276:E672-83.

6. Jeukendrup $A E$, Jentjens $R$. Oxidation of carbohydrate feedings during prolonged exercise: current thoughts, guidelines and directions for future research. Sports Med. 2000;29:407-24.

7. Jeukendrup AE. Carbohydrate and exercise performance: the role of multiple transportable carbohydrates. Curr Opin Clin Nutr Metab Care. 2010;13:452-7.

8. Jentjens RLPG, Moseley L, Waring RH, Harding LK, Jeukendrup AE. Oxidation of combined ingestion of glucose and fructose during exercise. J Appl Physiol (1985). 2004;96:1277-84.

9. Davidson RE, Leese HJ. Sucrose absorption by the rat small intestine in vivo and in vitro. J Physiol. 1977;267:237-48.

10. Ferraris RP, Diamond J. Regulation of intestinal sugar transport. Physiol Rev. 1997;77:257-302.

11. Sandle GI, Lobley RW, Warwick R, Holmes R. Monosaccharide absorption and water secretion during disaccharide perfusion of the human jejunum. Digestion. 1983;26:53-60.

12. DeBosch BJ, Chi M, Moley KH. Glucose transporter 8 (GLUT8) regulates enterocyte fructose transport and global mammalian fructose utilization. Endocrinology. 2012;153:4181-91.

13. Leturque A, Brot-Laroche E, Le Gall M, Stolarczyk E, Tobin V. The role of GLUT2 in dietary sugar handling. J Physiol Biochem. 2005;61:529-37.

14. Rowlands DS, Houltham S, Musa-Veloso K, Brown F, Paulionis L, Bailey D. Fructose-Glucose Composite Carbohydrates and Endurance Performance: Critical Review and Future Perspectives. Sports Med. 2015;45:1561-76.

15. Shi X, Summers RW, Schedl HP, Flanagan SW, Chang R, Gisolfi CV. Effects of carbohydrate type and concentration and solution osmolality on water absorption. Medicine \& Science in Sports \& Exercise. 1995;27:1607-15.

16. Wallis GA, Rowlands DS, Shaw C, Jentjens RLPG, Jeukendrup AE. Oxidation of Combined Ingestion of Maltodextrins and Fructose during Exercise. Medicine \& Science in Sports \& Exercise. 2005;37:426-32.

17. Wallis GA, Wittekind $A$. Is there a specific role for sucrose in sports and exercise performance? Int J Sport Nutr Exerc Metab. 2013;23:571-83.

18. Likely R, Johnson E, Ahearn GA. Functional characterization of a putative disaccharide membrane transporter in crustacean intestine. J Comp Physiol B. 2015;185:173-83. 
19. Jentjens RLPG, Shaw C, Birtles T, Waring RH, Harding LK, Jeukendrup AE. Oxidation of combined ingestion of glucose and sucrose during exercise. Metabolism. 2005;54:610-8.

20. Jentjens RLPG, Venables MC, Jeukendrup AE. Oxidation of exogenous glucose, sucrose, and maltose during prolonged cycling exercise. J Appl Physiol (1985). 2004;96:1285-91.

21. Jentjens RLPG, Jeukendrup AE. High rates of exogenous carbohydrate oxidation from a mixture of glucose and fructose ingested during prolonged cycling exercise. Br J Nutr. 2005;93:485-92.

22. Roberts JD, Tarpey MD, Kass LS, Tarpey RJ, Roberts MG. Assessing a commercially available sports drink on exogenous carbohydrate oxidation, fluid delivery and sustained exercise performance. J Int Soc Sports Nutr. 2014;11:8.

23. van Wijck K, Lenaerts K, van Loon LJC, Peters WHM, Buurman WA, Dejong CHC. Exerciseinduced splanchnic hypoperfusion results in gut dysfunction in healthy men. PLoS One. 2011;6:e22366.

24. van Wijck K, Lenaerts K, Grootjans J, Wijnands KAP, Poeze M, van Loon LJC, et al. Physiology and pathophysiology of splanchnic hypoperfusion and intestinal injury during exercise: strategies for evaluation and prevention. Am J Physiol Gastrointest Liver Physiol. 2012;303:G155-68.

25. Chou CC, Coatney RW. Nutrient-induced changes in intestinal blood flow in the dog. Br Vet J. 1994;150:423-37.

26. Gentilcore D, Nair NS, Vanis L, Rayner CK, Meyer JH, Hausken T, et al. Comparative effects of oral and intraduodenal glucose on blood pressure, heart rate, and splanchnic blood flow in healthy older subjects. Am J Physiol Regul Integr Comp Physiol. 2009;297:R716-22.

27. Cermak NM, Gibala MJ, van Loon LJC. Nitrate supplementation's improvement of 10-km timetrial performance in trained cyclists. Int J Sport Nutr Exerc Metab. 2012;22:64-71.

28. Borg G. Ratings of perceived exertion and heart rates during short-term cycle exercise and their use in a new cycling strength test. Int J Sports Med. 1982;3:153-8.

29. van Wijck K, Wijnands KAP, Meesters DM, Boonen B, van Loon LJC, Buurman WA, et al. LCitrulline Improves Splanchnic Perfusion and Reduces Gut Injury during Exercise. Medicine \& Science in Sports \& Exercise. 2014;46:2039-46.

30. Frayn KN. Calculation of substrate oxidation rates in vivo from gaseous exchange. J Appl Physiol (1985). 1983;55:628-34.

31. Craig H. Isotopic standards for carbon and oxygen and correction factors for mass-spectrometric analysis of carbon dioxide. Geochimica et cosmochimica acta. Elsevier; 1957;12:133-49.

32. Pirnay F, Lacroix M, Mosora F, Luyckx A, Lefebvre P. Glucose oxidation during prolonged exercise evaluated with naturally labeled [13C] glucose. Journal of Applied Physiology. Am Physiological Soc; 1977;43:258-61.

33. Robert JJ, Koziet J, Chauvet D, Darmaun D, Desjeux JF, Young VR. Use of 13C-labeled glucose for estimating glucose oxidation: some design considerations. J Appl Physiol (1985). 1987;63:1725-32.

34. Pallikarakis N, Sphiris N, Lefebvre P. Influence of the bicarbonate pool and on the occurrence of $13 \mathrm{CO} 2$ in exhaled air. Eur J Appl Physiol Occup Physiol. 1991;63:179-83.

35. Wagenmakers AJ, Brouns F, Saris WH, Halliday D. Oxidation rates of orally ingested carbohydrates during prolonged exercise in men. J Appl Physiol (1985). 1993;75:2774-80. 
36. Rowlands DS, Wallis GA, Shaw C, Jentjens RLPG, Jeukendrup AE. Glucose polymer molecular weight does not affect exogenous carbohydrate oxidation. Medicine \& Science in Sports \& Exercise. 2005;37:1510-6.

37. Jentjens RLPG, Achten J, Jeukendrup AE. High oxidation rates from combined carbohydrates ingested during exercise. Medicine \& Science in Sports \& Exercise. 2004;36:1551-8.

38. Laughlin MR. Normal roles for dietary fructose in carbohydrate metabolism. Nutrients. 2014;6:3117-29.

39. Gonzalez JT, Fuchs CJ, Smith FE, Thelwall PE, Taylor R, Stevenson EJ, et al. Ingestion of glucose or sucrose prevents liver but not muscle glycogen depletion during prolonged endurance-type exercise in trained cyclists. Am J Physiol Endocrinol Metab. 2015;309:E1032-9.

40. Lecoultre V, Benoit R, Carrel G, Schutz Y, Millet GP, Tappy L, et al. Fructose and glucose coingestion during prolonged exercise increases lactate and glucose fluxes and oxidation compared with an equimolar intake of glucose. Am J Clin Nutr. 2010;92:1071-9.

41. Baur DA, Schroer AB, Luden ND, Womack CJ, Smyth SA, Saunders MJ. Glucose-fructose enhances performance versus isocaloric, but not moderate, glucose. Medicine \& Science in Sports \& Exercise. 2014;46:1778-86.

42. Currell K, Jeukendrup AE. Superior endurance performance with ingestion of multiple transportable carbohydrates. Medicine \& Science in Sports \& Exercise. 2008;40:275-81.

43. Rowlands DS, Swift M, Ros M, Green JG. Composite versus single transportable carbohydrate solution enhances race and laboratory cycling performance. Appl. Physiol. Nutr. Metab. 2012;37:425-36.

44. Brooks GA, Dubouchaud H, Brown M, Sicurello JP, Butz CE. Role of mitochondrial lactate dehydrogenase and lactate oxidation in the intracellular lactate shuttle. Proc Natl Acad Sci U S A. 1999;96:1129-34.

45. Tappy L, Egli L, Lecoultre V, Schneider P. Effects of fructose-containing caloric sweeteners on resting energy expenditure and energy efficiency: a review of human trials. Nutrition \& Metabolism. 2013;10:54. 



\section{Chapter 3}

A sucrose mouth rinse does not improve $1 \mathrm{~h}$ cycle time trial performance when performed in the fasted or fed state

Jorn Trommelen; Milou Beelen; Marjan Mullers; Martin J. Gibala; Luc J.C. van Loon; Naomi M. Cermak

Int J Sport Nutr Exerc Metab. 2015 Dec;25(6):576-83 


\section{ABSTRACT}

Background: Carbohydrate mouth rinsing during exercise has been suggested to enhance performance of short (45-60 $\mathrm{min}$ ) bouts of high-intensity ( $>75 \% \mathrm{VO}_{2 \text { peak }}$ ) exercise. Recent studies indicate that this performance enhancing effect may be dependent on the prandial state of the athlete.

Purpose: To define the impact of a carbohydrate mouth rinse on $\sim 1 \mathrm{~h}$ time trial performance in both the fasted and fed states.

Methods: Using a double blind, crossover design, 14 trained male cyclists $\left(27 \pm 6\right.$ y; $\left.5.0 \pm 0.5 \mathrm{~W} \cdot \mathrm{kg}^{-1}\right)$ were selected to perform 4 time trials of $\sim 1 \mathrm{~h}(1032 \pm 127 \mathrm{~kJ})$ on a cycle ergometer while rinsing their mouths with a $6.4 \%$ sucrose solution (SUC) or a non-caloric sweetened placebo (PLA) for $5 \mathrm{~s}$ at the start and at every $12.5 \%$ of their set amount of work completed. Two trials were performed in an overnight fasted state and two trials were performed $2 \mathrm{~h}$ after consuming a standardized breakfast.

Results: Performance time did not differ between any of the trials (fasted-PLA: 68.6 \pm 7.2 , fasted-SUC: 69.6 \pm 7.5 , fed-PLA: $67.6 \pm 6.6$ and fed-SUC: $69.0 \pm 6.3 \mathrm{~min}$; prandial state $x$ mouth rinse solution $P=0.839$; main effect prandial state $P=0.095$; main effect mouth rinse solution $P=0.277$ ). In line, mean power output and heart rate during exercise did not differ between trials.

Conclusion: A sucrose mouth rinse does not improve $\sim 1 \mathrm{~h}$ time trial performance in well-trained cyclists when performed in either the fasted or the fed state. 


\section{INTRODUCTION}

It has been well-established that carbohydrate ingestion during prolonged ( $>2 \mathrm{~h}$ ), endurance-type exercise can delay the onset of fatigue and improve endurance performance [1-8], likely due to the sparing of limited endogenous glycogen stores [4, 9-14]. However, the ergogenic benefits of carbohydrate ingestion during exercise may not be limited to more prolonged, endurance-type exercise events. Improvements in performance have been reported following carbohydrate ingestion during relatively short ( $<60 \mathrm{~min}$ ) bouts of high-intensity $\left(>75 \% \mathrm{VO}_{2 \text { peak }}\right.$ ) exercise [15-19].

Jeukendrup and colleagues reported a $2.3 \%$ improvement in performance during a $\sim 1 \mathrm{~h}$ cycling timetrial, when carbohydrate was ingested at regular intervals [19]. However, in a follow-up study no performance benefits were observed following intravenous infusion of glucose during a $\sim 1 \mathrm{~h}$ cycling time trial [20]. As carbohydrate availability did not seem to limit performance capacity during highintensity exercise of such a short duration, the authors speculated that simply the presence of glucose in the mouth may have been ergogenic [20]. In agreement, they subsequently demonstrated that when a $6.4 \%$ maltodextrin solution was rinsed around the mouth for every $12.5 \%$ of the trial completed, performance during a $1 \mathrm{~h}$ time trial was increased by $2.8 \%$ [21].

Since then, more studies have reported ergogenic benefits of a carbohydrate mouth rinse during shortterm, high-intensity exercise (30-60 $\mathrm{min},>75 \% \mathrm{VO}_{2 \text { peak }}$ ) [22-29], whereas others have been unable to confirm those findings [27, 30-32]. The mechanism(s) responsible for the ergogenic properties of a carbohydrate mouth rinse may involve a signaling response from carbohydrate receptors in the mouth to the central nervous system, increasing central drive. In accordance, several studies have now reported the presence of carbohydrate in the mouth to facilitate corticomotor output [33, 34]. We previously speculated that from an evolutionary view the signaling response of carbohydrate mouth rinsing on the central nervous system would be less effective in the fed state, when liver glycogen stores are not compromised. Consequently, we showed no improvement in $\sim 1 \mathrm{~h}$ cycling time trial performance when subjects rinsed their mouths with a carbohydrate versus placebo solution during exercise performed in the fed state [35]. However, a limitation of our previous work is that we did not assess the effect of carbohydrate mouth rinsing in a fasted state in the same cohort of athletes. Since then, two studies have been published showing improvements in time-to-exhaustion and time trial performance in both the post-absorptive and post-prandial state [22, 23]. In the present study, we assessed the impact of a carbohydrate mouth rinse on $1 \mathrm{~h}$ time trial performance in both the postabsorptive and post-prandial state in well-trained cyclists. We hypothesized that a carbohydrate mouth rinse improves $1 \mathrm{~h}$ time trial performance when exercise is performed in a fasted, post-absorptive state, with no apparent ergogenic benefit when exercise is performed in the post-prandial state. 


\section{METHODS}

\section{Subjects}

Fourteen trained male cyclists or triathletes $\left(27 \pm 6 \mathrm{y} ; 1.83 \pm 0.08 \mathrm{~m} ; 78 \pm 11 \mathrm{~kg}, 5.0 \pm 0.5 \mathrm{~W}^{\circ} \mathrm{kg}^{-1}\right)$ were selected to participate in the study. All subjects had been engaged in regular cycling training $(>4$ times/wk) for $>6$ years. After being advised on the purpose and potential risks of the study, all subjects provided written, informed consent. The experimental protocol and procedures were approved by the Medical Ethical Committee of the Academic Hospital Maastricht, The Netherlands.

\section{Study design}

The study was designed to investigate whether a carbohydrate mouth rinse improves $\sim 1 \mathrm{~h}$ time trial performance in the post-absorptive and post-prandial state. The experimental protocol consisted of 6 visits to the laboratory, which was maintained at $21 \pm 0.5{ }^{\circ} \mathrm{C}$ with a relative humidity of $60 \pm 5 \%$. All exercise tests were carried out on an electronically braked cycle ergometer (Lode Excalibur, Groningen, The Netherlands). The first visit included an incremental cycling exercise test to exhaustion to determine subjects' maximal workload capacity $\left(\mathrm{W}_{\max }\right)$. Visits 2-6 consisted of simulated time trials in which a set amount of work had to be performed within the shortest time possible. The second visit consisted of a familiarization session whereby subjects were given water to rinse around their mouths' at pre-determined intervals. Thereafter, subjects performed 4 experimental trials, during which the subjects were given either a $6.4 \%$ sucrose solution (SUC) or a non-caloric aspartame sweetened placebo (PLA) to rinse around their mouths at pre-determined intervals. The experimental trials were performed in a double-blind, counter-balanced order with trials separated by at least 1 week.

\section{Maximal workload capacity}

Subjects' maximal relative workload capacity was assessed during a step-wise exercise test to exhaustion on an electronically braked cycle ergometer (Lode Excalibur, Groningen, The Netherlands). After a 5-min warm-up at $100 \mathrm{~W}$, workload was set at $150 \mathrm{~W}$ and increased by $50 \mathrm{~W}$ every 2.5 min until voluntary exhaustion [36]. Workload (W), cadence (rpm) and heart rate (Polar, Kempele, Finland) were recorded at every interval. The appropriate seat position, handlebar height and orientation were determined and replicated for each subject's subsequent visit. Maximal workload capacity $\left(\mathrm{W}_{\max }\right)$ was calculated as the workload in the last completed stage + workload relative to the time spent in the last incomplete stage ((time in sec) / $150 * 50(\mathrm{~W}))$.

\section{Physical activity and dietary standardization}

Subjects kept their weekly training schedule consistent over the course of the experiment, standardized their workouts $48 \mathrm{~h}$ before each experimental trial and refrained from physical exercise and exhaustive physical labor for $24 \mathrm{~h}$ before each experimental trial. Subjects recorded their physical activity and habitual diet for the $48 \mathrm{~h}$ period before the first experimental trial and replicated this regimen during the $48 \mathrm{~h}$ period prior to each subsequent trial. The evening before each experimental trial, subjects consumed a standardized dinner ( $68 \pm 4 \mathrm{~kJ} / \mathrm{kg}$, providing $60 \pm 5$ energy\% (En\%) carbohydrate, $25 \pm 2 \mathrm{En} \%$ fat, and $15 \pm 2$ En\% protein), after which they remained fasted. In the experimental trials performed in the post-prandial state a standardized breakfast was consumed $2 \mathrm{~h}$ prior to starting the time trial. This breakfast provided $36 \pm 2 \mathrm{~kJ} / \mathrm{kg}(65 \pm 7 \mathrm{En} \%$ carbohydrate, $18 \pm 4 \mathrm{En} \%$ fat, and $17 \pm 3 \mathrm{En} \%$ protein) and 
was composed of bread with butter, cheese and marmalade, a slice of ginger bread and a glass of orange juice.

\section{Time Trials}

For the four main experimental trials, all subjects reported to the laboratory at 8:00 am after an overnight fast. During the two fed experimental trials, subjects received a standardized breakfast (36 \pm 2 $\mathrm{kJ} / \mathrm{kg}$, providing $65 \pm 7 \mathrm{En} \%$ carbohydrate, $18 \pm 4 \mathrm{En} \%$ fat, and $17 \pm 3 \mathrm{En} \%$ protein). Two hours later (between 10.00-10.30 h), subjects started the time trials. Prior to the start of the time trials, subjects were fitted with a heart rate monitor and positioned on the cycle ergometer. After a 5-min warm-up at $100 \mathrm{~W}$, subjects were instructed to perform a set amount of work $(1032 \pm 127 \mathrm{~kJ})$ in the shortest time possible. Total work to be performed for each subject was calculated according to the equation of Jeukendrup and colleagues [37]: Total amount of work $=0.75 \times W_{\max } \times 3600$, where $W_{\max }$ is the maximal workload capacity determined during visit 1 and 3600 is the duration of the predicted total performance time in seconds (equivalent to $1 \mathrm{~h}$ ). The approximate one hour exercise duration was selected to invoke a relatively high-intensity, yet non-glycogen limiting exercise bout $[19,38]$. The ergometer was set in linear mode so that $75 \% \mathrm{~W}_{\max }$ was obtained when the subjects cycled at their preferred cycling cadence $(100 \pm 8 \mathrm{rpm})$, determined during the maximal workload capacity test. Subjects received no temporal, verbal or physiological feedback during the time trial. The only information available to the subject was the total work performed relative to the set amount of work that needed to be completed, which was displayed on a computer screen set-up in front of the ergometer. A fan was placed $1 \mathrm{~m}$ behind each subject to provide cooling and air circulation during the time trials. At the start and at every $12.5 \%$ of the time trial completed, subjects received $25 \mathrm{~mL}$ of the test solution to rinse around their mouth. Heart rate (Polar, Kempele, Finland), power output and cadence were recorded continuously throughout the test. During each time trial, no interaction occurred between the subject and the investigator except for the mouth rinse administration. Subjects did not receive any verbal encouragement except for the last $10 \mathrm{~kJ}$ of the test, whereby the investigator counted down the remaining $\mathrm{kJ}$ from 10 to 0 , indicating the completion of the test. During the trials and over the course of the experiment, subjects were kept unaware of any performance-related information such as exercise time, heart rate, power output and cycling cadence.

\section{Mouth-rinse protocol}

Each subject was given a $25 \mathrm{~mL}$ bolus of either a $6.4 \%$ sucrose solution (SUC), or a non-caloric $0.6 \%$ aspartame sweetened placebo (PLA) at the start and after every $12.5 \%$ of the time trial completed. Subjects rinsed the fluid around their mouth for $5 \mathrm{~s}$ and then spat it into a bowl held by an investigator. Trial order was randomized via a random-number generator (www.random.org) and beverages were prepared and coded by a non-affiliated researcher to ensure double blinding.

\section{Statistical analyses}

Performance data were analyzed using a two-way (prandial state $x$ mouth rinse solution) repeated measures analysis of variance (ANOVA). A three-way repeated measures ANOVA with prandial state $x$ mouth rinse solution $x$ time as factors was used to compare differences between trials over time. The level of significance for all analyses was set at $P<0.05$. All data are presented as means $\pm S D, n=14$ unless otherwise stated. 


\section{RESULTS}

\section{Performance time and power output}

Performance time of the four time-trials is shown in Figure 3.1. Performance time did not differ between any of the trials (fasted-PLA: $68.6 \pm 7.2 \mathrm{~min}$; fasted-SUC: $69.6 \pm 7.5 \mathrm{~min}$; fed-PLA: $67.6 \pm 6.6 \mathrm{~min}$; fed-SUC: 69.0 \pm 6.3 min; prandial state $x$ mouth rinse solution $P=0.839$; main effect prandial state $P=0.095$; main effect mouth rinse solution $P=0.277$ ). Average power output of the four time-trials is shown in Figure 3.2. Average power output did not differ between any of the trials (fasted-PLA: $255 \pm 43 \mathrm{~W}$, fasted-SUC: $252 \pm 46 \mathrm{~W}$, fed-PLA: $258 \pm 45 \mathrm{~W}$, and fed-SUC: $253 \pm 41 \mathrm{~W}$; prandial state $\mathrm{x}$ mouth rinse solution $P=0.725$; main effect prandial state $P=0.111$; main effect mouth rinse solution $P=0.380$ ). The average power outputs for every $12.5 \%$ of the time trial completed in the fasted and fed state are presented in Figure 3.3. No differences were observed in power output over time between trials (prandial state $x$ mouth rinse solution $x$ time $P=0.265$ ).

\section{Heart rate and RPM data}

Mean heart rate during the four time-trials did not differ between trials (fasted-PLA: $161 \pm 8 \mathrm{bpm}$, fastedSUC: $160 \pm 10 \mathrm{bpm}$, fed-PLA: $164 \pm 10 \mathrm{bpm}$, and fed-SUC: $163 \pm 8 \mathrm{bpm} ; n=12$; prandial state $\mathrm{x}$ mouth rinse solution $P=0.725$ ). Mean RPM did not differ between the four time-trials (fasted-PLA: $97 \pm 7$ rpm, fasted-SUC: $96 \pm 9 \mathrm{rpm}$, fed-PLA: $98 \pm 9 \mathrm{rpm}$, fed-SUC: $98 \pm 8 \mathrm{rpm}$; prandial state $\mathrm{x}$ mouth rinse solution $P=0.488)$

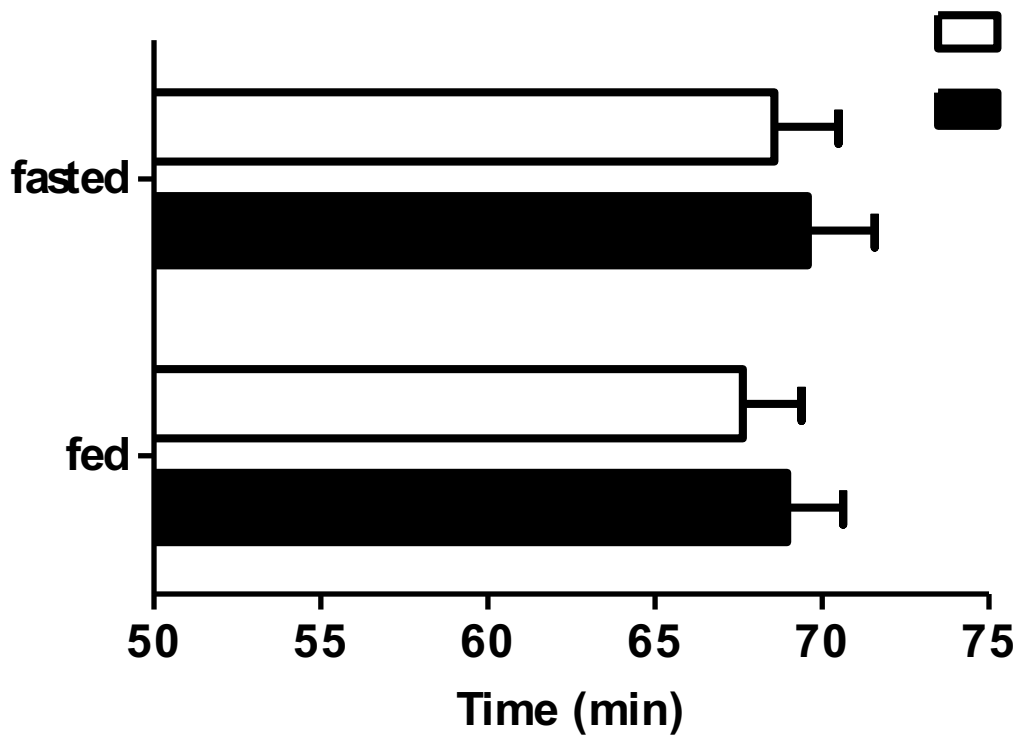

Figure 3.1. Performance times in the placebo and sucrose treatments in both the fasted and fed state. No significant differences between trials; prandial state $x$ mouth rinse solution, $P>0.05)$. Values are expressed as mean \pm SD. SUC: sucrose mouth rinse, PLA = placebo mouth rinse. 


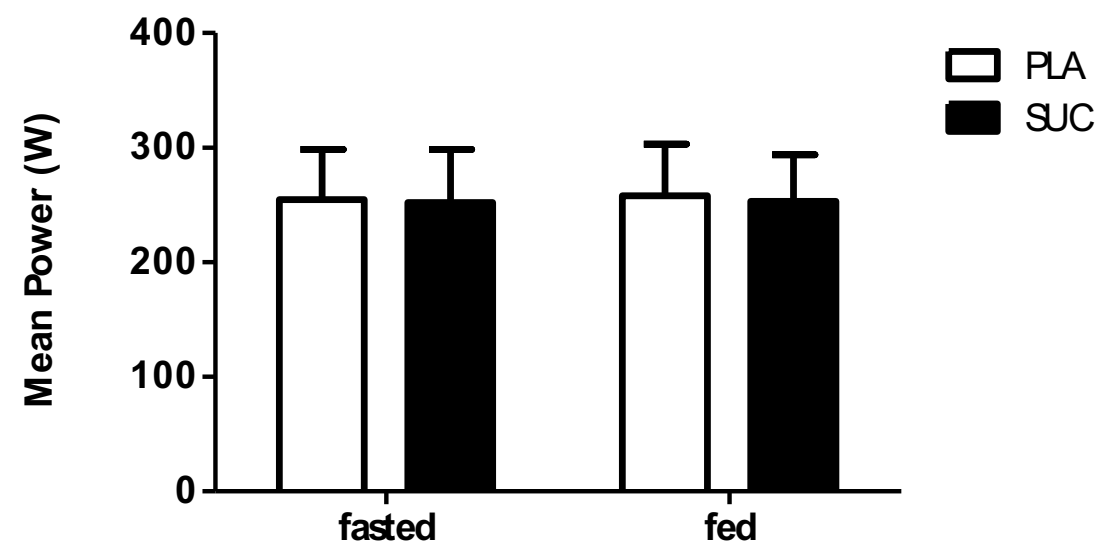

Figure 3.2. Mean power output in the placebo and sucrose treatments in both the fasted and fed state. No significant differences between trials; prandial state $x$ mouth rinse solution, $P>0.05$ ). Values are expressed as mean $\pm S D$. SUC: sucrose mouth rinse, PLA = placebo mouth rinse.

\section{Individual changes in power}

Individual and mean changes in power output between the time-trials performed in the fasted and fed state are shown in Figure 3.4. In the fasted state, five subjects performed the time trial faster while using the carbohydrate mouth rinse, while nine performed better using the placebo mouth rinse. In the fed state, five subjects performed the time trial faster while receiving the carbohydrate mouth rinse, while nine performed better when receiving the PLA mouth rinse. Only one subject performed the time trial faster with the carbohydrate compared to placebo mouth rinse in both the fasted and fed state.
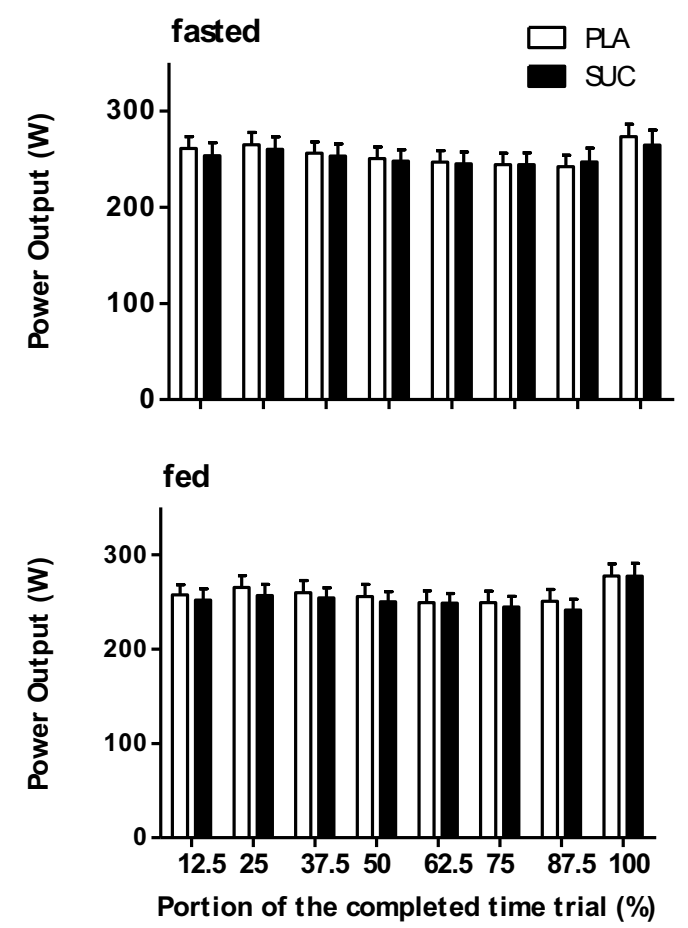

Figure 3.3. Mean power output for each $12.5 \%$ of total work completed in the placebo and sucrose treatment in both the fasted and fed state. No significant differences between trials prandial state $x$ mouth rinse solution $x$ time; $P>0.05)$. Values are expressed as mean \pm SD. SUC: sucrose mouth rinse, PLA = placebo mouth rinse. 


\section{fasted}

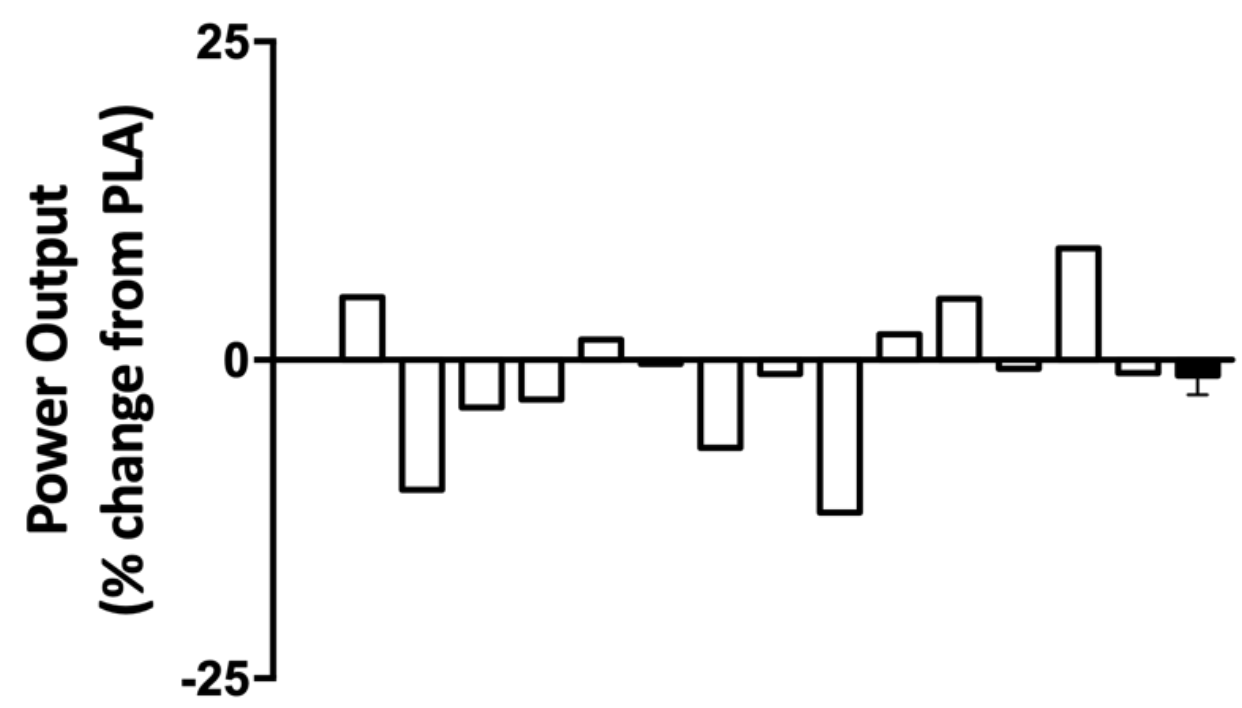

fed

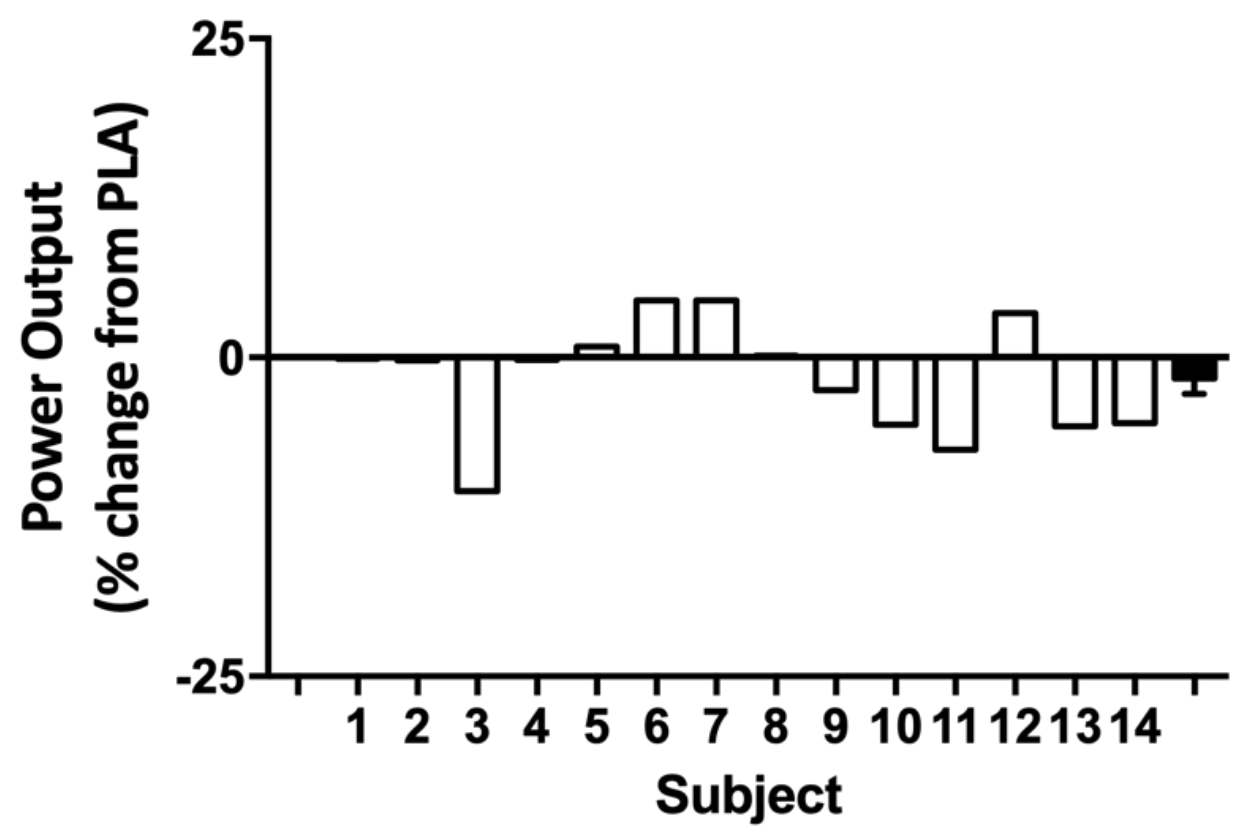

Figure 3.4. Individual (transparent bars) and mean (solid bars) change in mean power output in the placebo and sucrose treatments in both the fasted and fed state. Values are expressed as mean \pm SD. PLA = placebo mouth rinse. A positive \%change in power output indicates improved exercise performance. 


\section{DISCUSSION}

In the current study we observed no increase in $1 \mathrm{~h}$ time trial performance following mouth rinsing with sucrose compared with a placebo during exercise in well-trained cyclists in both the post-absorptive as well as post-prandial state.

Several studies have reported that carbohydrate mouth rinsing can improve short-term, high-intensity (30-60 min, (>75\% VO $\mathrm{V}_{\text {2peak }}$ ) endurance-type exercise performance [21-29], whereas others have failed to confirm those findings $[26,30,32,35]$. A factor that has been proposed to explain the discrepancy between these studies is the duration of the pre-exercise fasting period. We previously proposed that the signaling response from carbohydrate receptors in the oral cavity to the central nervous system may be of lesser magnitude when exercise is performed in the fed state, a situation where liver glycogen stores are not compromised. In agreement, we previously observed no improvements in performance following carbohydrate mouth-rinsing during exercise performed in a fed state [35]. We hypothesized that carbohydrate mouth-rinsing during high-intensity exercise increases time trial performance only when exercise is performed in a post-absorptive, overnight fasted state.

To test this hypothesis, we assessed the effect of sucrose mouth-rinsing on $1 \mathrm{~h}$ time-trial performance in both the post-prandial as well as the overnight fasted state. In agreement with our hypothesis, we observed no increase in time-trial performance following sucrose mouth- rinsing compared to placebo (fed-SUC: $69.0 \pm 6.3 \mathrm{~min}$; fed-PLA: $67.6 \pm 6.6 \mathrm{~min}$, Figure 3.1), when exercise was performed $2 \mathrm{~h}$ after the consumption of a carbohydrate-rich breakfast $(1.38 \pm 0.16 \mathrm{~g}$ carbohydrate $/ \mathrm{kg} \mathrm{BM})$. These findings confirm previous work in our laboratory, in which we failed to detect any ergogenic properties of a carbohydrate mouth rinse on time trial performance assessed in the fed state [35]. To date, only two other studies have investigated the impact of carbohydrate mouth rinsing on high-intensity endurance exercise performed in the fed state [22, 23]. In contrast to our findings, both Fares et al. [22] and Lane et al. [23] have reported improvements in time-trial performance when carbohydrate mouth rinsing was started 2-3 h after consuming a carbohydrate-rich breakfast. The discrepancy with our previous [35] and present observation is not clear. A difference between these studies is the carbohydrate concentration of the mouth rinse solution. Lane et al. applied a 10\% carbohydrate solution [23], while we used a $6.4 \%$ solution in our current and previous work [35]. In contrast, Fares et al. also applied a $6.4 \%$ solution [22] and observed an ergogenic effect of mouth rinsing on time trial performance in trained athletes. Therefore, differences in carbohydrate concentration do not seem to explain the discrepancy among studies. A factor that may explain the inconsistency between studies is the duration of the applied mouth rinse. While we applied $5 \mathrm{~s}$ mouth rinses in our previous [35] and current investigation, Fares et al. [22] and Lane et al. [23] applied longer rinsing protocols of 5-10 and $10 \mathrm{~s}$, respectively. In support, a recent study on the duration of carbohydrate mouth rinsing suggests greater ergogenic effects following a $10 \mathrm{~s}$ versus a $5 \mathrm{~s}$ rinsing protocol [27].

We investigated the impact of sucrose mouth rinsing on exercise performance during both the postabsorptive as well as post-prandial state. In contrast to our hypothesis, we observed no ergogenic effects of sucrose mouth rinsing during exercise in the fasted state (fasted-SUC: $69.6 \pm 7.5 \mathrm{~min}$; fastedPLA: $68.6 \pm 7.2 \mathrm{~min}$, Figure 3.1). Many previous studies have reported improvements in exercise performance with carbohydrate mouth rinsing applied $>4 \mathrm{~h}$ after ingesting the last meal [21-23, 25-29]. However, there are also other studies that have failed to confirm these findings [27, 30, 32]. The reason 
for the discrepancy between these studies, including the present, is not readily apparent. The current study was very similar in design to previous investigations on carbohydrate mouth rinsing during exercise in a fasted state [21-28, 32]. We included 14 well-trained cyclists and their time trial performance showed a coefficient of variation of $2.66 \%$ and $3.33 \%$ when performance was assessed in the fasted and fed state, respectively. The test-retest reliability in our athletes is similar to previous reports on the validity of time trials as a means to assess exercise performance in a laboratory setting [37]. This implies that our statistical power was strong enough to detect ergogenic benefits as small as $2.5 \%$ between trials. In addition, when looking at individual data, 9 out of 14 subjects had a lower power output during the sucrose mouth rinse trial when compared with the placebo mouth rinse trial (Figure 3.4), further supporting the suggestion that there was no lack of statistical power. It can be speculated that our use of the artificial sweetener aspartame as placebo, which can bind to oral taste receptors, may have concealed a potential ergogenic effect of carbohydrate mouth rinsing. However, as has been shown by $\mathrm{fMRl}$, the caloric content of carbohydrates triggers additional oral sensing pathways that are thought to mediate the improvement in exercise performance when carbohydrates are present in the mouth [28]. In agreement, previous studies have reported ergogenic effects of carbohydrate mouth rinsing compared to artificial sweeteners used in the placebo beverages [23, 24, $28,29]$. Taken together, previous studies show that the use of artificial sweeteners is appropriate as a placebo treatment for carbohydrate mouth rinse studies. One difference between our study and others is that we used sucrose as type of carbohydrate, whereas most other studies have applied glucose [25, $28,31]$ or maltodextrin $[21-23,26-28,32]$. However, similar to glucose and maltodextrin $[28,39]$, the presence of sucrose in the mouth has been shown to stimulate cortical activation [40] and improve working memory performance [41], effects that are suggested to be the mechanisms by which carbohydrate mouth rinsing improves endurance performance [28, 39]. Nonetheless, few studies have applied sucrose mouth-rinsing to enhance exercise performance [24]. Finally, we need to underline the possibility of publication bias in the literature regarding the proposed ergogenic benefits of carbohydrate mouth rinsing. We stress the importance for so-called negative studies to be submitted and published in the literature, as we feel that empirical evidence regarding the practical benefits carbohydrate mouth rinsing remain to be established.

Since competition is mostly performed in fed conditions, the proposed ergogenic benefit of carbohydrate mouth rinsing is of limited practical relevance when performed in fasted conditions. There are only few data investigating the impact of carbohydrate mouth rinsing in fed conditions [22, 23, 35]. Our previous [35] and present data fail to detect any measurable increases in exercise performance following a carbohydrate mouth rinse in the fasted or fed state in well-trained athletes. Taken together, we feel there is not sufficient evidence to recommend athletes to implement carbohydrate mouth rinsing during competition in a real-life setting.

In conclusion, a sucrose mouth rinse applied during exercise does not improve $\sim 1 \mathrm{~h}$ cycling time-trial performance in well trained cyclists in the fasted or post-prandial state.

\section{ACKNOWLEDGEMENTS}

We gratefully acknowledge the assistance of Janneau van Kranenburg and the enthusiastic support of the volunteers who participated in these experiments. The study was designed by LL, MG and NC, 
data were collected and analyzed by JT, MM, NC, data interpretation and manuscript preparation were undertaken by JT, MB, LL, NC. All authors approved the final version of the paper.

\section{DECLARATION OF FUNDING SOURCE}

This project was partly funded by a research grant from Kenniscentrum Suiker \& Voeding, Utrecht, the Netherlands and the Sugar Nutrition UK., London, United Kingdom. 


\section{REFERENCES}

1. Coyle EF, Coggan AR, Hemmert M, Ivy JL. Muscle glycogen utilization during prolonged strenuous exercise when fed carbohydrate. J Appl Physiol. 1986;61(1):165-72.

2. Coyle E, Hagberg J, Hurley B, Martin W, Ehsani A, Holloszy J. Carbohydrate feeding during prolonged strenuous exercise can delay fatigue. Journal of applied physiology: respiratory, environmental and exercise physiology. 1983;55(1 Pt 1):230-5.

3. Fielding R, Costill D, Fink W, King D, Hargreaves M, Kovaleski J. Effect of carbohydrate feeding frequencies and dosage on muscle glycogen use during exercise. Medicine and Science in Sports and Exercise. 1985;17(4):472-6.

4. Hargreaves M, Costill D, Coggan A, Fink W, Nishibata I. Effect of carbohydrate feedings on muscle glycogen utilization and exercise performance. Medicine and Science in Sports and Exercise. 1984;16(3):219-22.

5. Ivy J, Costill D, Fink W, Lower R. Influence of caffeine and carbohydrate feedings on endurance performance. Medicine and Science in Sports. 1978;11(1):6-11.

6. Mitchell JB, Costill DL, Houmard JA, Flynn MG, Fink WJ, Beltz JD. Effects of carbohydrate ingestion on gastric emptying and exercise performance. Med Sci Sports Exerc. 1988 Apr;20(2):110-5.

7. Neufer PD, Costill DL, Flynn MG, Kirwan JP, Mitchell JB, Houmard J. Improvements in exercise performance: effects of carbohydrate feedings and diet. Journal of applied physiology (Bethesda, Md : 1985). 1987 Mar;62(3):983-8.

8. Jeukendrup AE. Carbohydrate intake during exercise and performance. Nutrition (Burbank, Los Angeles County, Calif). 2004 Jul-Aug;20(7-8):669-77.

9. Bjorkman $\mathrm{O}$, Sahlin $\mathrm{K}$, Hagenfeldt $\mathrm{L}$, Wahren J. Influence of glucose and fructose ingestion on the capacity for long-term exercise in well-trained men. Clinical physiology (Oxford, England). 1984 Dec;4(6):483-94.

10. Erickson MA, Schwarzkopf RJ, McKenzie RD. Effects of caffeine, fructose, and glucose ingestion on muscle glycogen utilization during exercise. Med Sci Sports Exerc. 1987 Dec;19(6):579-83.

11. Stellingwerff $T$, Boon $H$, Gijsen AP, Stegen JH, Kuipers $H$, van Loon LJ. Carbohydrate supplementation during prolonged cycling exercise spares muscle glycogen but does not affect intramyocellular lipid use. Pflugers Archiv : European journal of physiology. 2007 Jul;454(4):635-47.

12. Tsintzas K, Williams C. Human muscle glycogen metabolism during exercise. Effect of carbohydrate supplementation. Sports medicine (Auckland, NZ). 1998 Jan;25(1):7-23.

13. Tsintzas OK, Williams C, Boobis L, Greenhaff P. Carbohydrate ingestion and glycogen utilization in different muscle fibre types in man. J Physiol. 1995 Nov 15;489 ( Pt 1):243-50.

14. Tsintzas K, Williams C, Constantin-Teodosiu D, Hultman E, Boobis L, Clarys P, et al. Phosphocreatine degradation in type I and type II muscle fibres during submaximal exercise in man: effect of carbohydrate ingestion. J Physiol. 2001 Nov 15;537(Pt 1):305-11.

15. Anantaraman R, Carmines AA, Gaesser GA, Weltman A. Effects of carbohydrate supplementation on performance during 1 hour of high-intensity exercise. International journal of sports medicine. 1995 Oct;16(7):461-5. 
16. Below PR, Mora-Rodriguez R, Gonzalez-Alonso J, Coyle EF. Fluid and carbohydrate ingestion independently improve performance during $1 \mathrm{~h}$ of intense exercise. Med Sci Sports Exerc. 1995 Feb;27(2):200-10.

17. Carter J, Jeukendrup AE, Mundel T, Jones DA. Carbohydrate supplementation improves moderate and high-intensity exercise in the heat. Pflugers Archiv : European journal of physiology. 2003 May;446(2):211-9.

18. el-Sayed MS, Balmer J, Rattu AJ. Carbohydrate ingestion improves endurance performance during a $1 \mathrm{~h}$ simulated cycling time trial. J Sports Sci. 1997 Apr;15(2):223-30.

19. Jeukendrup A, Brouns F, Wagenmakers AJ, Saris WH. Carbohydrate-electrolyte feedings improve $1 \mathrm{~h}$ time trial cycling performance. International journal of sports medicine. 1997 Feb;18(2):125-9.

20. Carter JM, Jeukendrup AE, Mann CH, Jones DA. The effect of glucose infusion on glucose kinetics during a 1-h time trial. Med Sci Sports Exerc. 2004 Sep;36(9):1543-50.

21. Carter JM, Jeukendrup AE, Jones DA. The effect of carbohydrate mouth rinse on 1-h cycle time trial performance. Medicine and science in sports and exercise. 2004;36(12):2107-11.

22. Fares E-J, Kayser B. Carbohydrate mouth rinse effects on exercise capacity in pre-and postprandial states. Journal of nutrition and metabolism. 2011;2011.

23. Lane SC, Bird SR, Burke LM, Hawley JA. Effect of a carbohydrate mouth rinse on simulated cycling time-trial performance commenced in a fed or fasted state. Applied Physiology, Nutrition, and Metabolism. 2012;38(2):134-9.

24. Pottier A, Bouckaert J, Gilis W, Roels T, Derave W. Mouth rinse but not ingestion of a carbohydrate solution improves 1-h cycle time trial performance. Scandinavian journal of medicine \& science in sports. 2010;20(1):105-11.

25. Rollo I, Cole M, Miller R, Williams C. Influence of mouth rinsing a carbohydrate solution on 1-h running performance. Medicine and science in sports and exercise. 2010;42(4):798-804.

26. Gam S, Guelfi KJ, Fournier PA. Opposition of carbohydrate in a mouth-rinse solution to the detrimental effect of mouth rinsing during cycling time trials. International journal of sport nutrition and exercise metabolism. 2013;23(1):48-56.

27. Sinclair J, Bottoms L, Flynn C, Bradley E, Alexander G, McCullagh S, et al. The effect of different durations of carbohydrate mouth rinse on cycling performance. European journal of sport science. 2014;14(3):259-64.

28. Chambers $E$, Bridge $M$, Jones $D$. Carbohydrate sensing in the human mouth: effects on exercise performance and brain activity. The Journal of Physiology. 2009;587(8):1779-94.

29. Rollo I, Williams C, Gant N, Nute M. The influence of carbohydrate mouth rinse on self-selected speeds during a 30-min treadmill run. International journal of sport nutrition. 2008;18(6):585.

30. Rollo I, Williams C, Nevill M. Influence of ingesting versus mouth rinsing a carbohydrate solution during a 1-h run. Medicine and science in sports and exercise. 2011;43(3):468-75.

31. Watson $P$, Nichols D, Cordery P. Mouth rinsing with a carbohydrate solution does not influence cycle time trial performance in the heat. Applied physiology, nutrition, and metabolism = Physiologie appliquee, nutrition et metabolisme. 2014 Sep;39(9):1064-9.

32. Whitham M, McKinney J. Effect of a carbohydrate mouthwash on running time-trial performance. Journal of sports sciences. 2007;25(12):1385-92. 
33. Gant N, Stinear CM, Byblow WD. Carbohydrate in the mouth immediately facilitates motor output. Brain research. 2010;1350:151-8.

34. Turner CE, Byblow WD, Stinear CM, Gant N. Carbohydrate in the mouth enhances activation of brain circuitry involved in motor performance and sensory perception. Appetite. 2014;80:212-9.

35. Beelen $M$, Berghuis J, Bonaparte $B$, Ballak SB, Jeukendrup AE, van Loon LJ. Carbohydrate mouth rinsing in the fed state: lack of enhancement of time-trial performance. International journal of sport nutrition. 2009;19(4):400.

36. Kuipers H, Verstappen FT, Keizer HA, Geurten P, van Kranenburg G. Variability of aerobic performance in the laboratory and its physiologic correlates. International journal of sports medicine. 1985 Aug;6(4):197-201.

37. Jeukendrup $A$, Saris WH, Brouns $F$, Kester AD. A new validated endurance performance test. Med Sci Sports Exerc. 1996 Feb;28(2):266-70.

38. McConell GK, Canny BJ, Daddo MC, Nance MJ, Snow RJ. Effect of carbohydrate ingestion on glucose kinetics and muscle metabolism during intense endurance exercise. Journal of applied physiology (Bethesda, Md : 1985). 2000 Nov;89(5):1690-8.

39. Molden DC, Hui CM, Scholer AA, Meier BP, Noreen EE, D'Agostino PR, et al. Motivational versus metabolic effects of carbohydrates on self-control. Psychological science. 2012 Oct 1;23(10):1137-44.

40. Haase L, Cerf-Ducastel B, Murphy C. Cortical activation in response to pure taste stimuli during the physiological states of hunger and satiety. Neuroimage. 2009;44(3):1008-21.

41. Carter EC, McCullough ME. After a pair of self-control-intensive tasks, sucrose swishing improves subsequent working memory performance. BMC psychology. 2013;1(1):22. 


\section{Chapter 4}

Fructose co-ingestion does not accelerate postexercise muscle glycogen repletion

Jorn Trommelen; Milou Beelen; Philippe J.M. Pinckaers; Joan M.

Senden; Naomi M. Cermak; Luc J.C. van Loon

Med Sci Sports Exerc. 2016 May;48(5):907-12 


\section{ABSTRACT}

Background: Post-exercise muscle glycogen repletion is largely determined by the systemic availability of exogenous carbohydrate provided.

Purpose: To assess the effect of the combined ingestion of fructose and glucose on post-exercise muscle glycogen repletion when optimal amounts of carbohydrate are ingested.

Methods: Fourteen male cyclists (age: $28 \pm 6 \mathrm{y} ; \mathrm{W}_{\text {max }}: 4.8 \pm 0.4 \mathrm{~W} \cdot \mathrm{kg}^{-1}$ ) were studied on 3 different occasions. Each test day started with a glycogen-depleting exercise session. This was followed by a 5 $\mathrm{h}$ recovery period, during which subjects ingested $1.5 \mathrm{~g} \cdot \mathrm{kg}^{-1} \cdot \mathrm{h}^{-1}$ glucose (GLU), $1.2 \mathrm{~g} \cdot \mathrm{kg}^{-1} \cdot \mathrm{h}^{-1}$ glucose $+0.3 \mathrm{~g} \cdot \mathrm{kg}^{-1} \cdot \mathrm{h}^{-1}$ fructose (GLU+FRU), or $0.9 \mathrm{~g} \cdot \mathrm{kg}^{-1} \cdot \mathrm{h}^{-1}$ glucose $+0.6 \mathrm{~g} \cdot \mathrm{kg}^{-1} \cdot \mathrm{h}^{-1}$ sucrose (GLU+SUC). Blood samples and gastrointestinal distress questionnaires were collected frequently and muscle biopsies were obtained at 0,120 , and 300 min after cessation of exercise to measure muscle glycogen content.

Results: Plasma glucose responses did not differ between treatments (ANOVA, $P=0.096$ ), but plasma insulin and lactate concentrations were elevated during GLU+FRU and GLU+SUC when compared to GLU $(P<0.01)$. Muscle glycogen content immediately following exercise averaged $207 \pm 112,219 \pm 107$ and $236 \pm 118 \mathrm{mmol} \cdot \mathrm{kg}^{-1}$ dry weight in the GLU, GLU+FRU and GLU+SUC treatment, respectively $(P=0.362)$. Carbohydrate ingestion increased muscle glycogen concentrations during $5 \mathrm{~h}$ of postexercise recovery to $261 \pm 98,289 \pm 130$ and $315 \pm 103 \mathrm{mmol} \cdot \mathrm{kg}^{-1}$ dry weight in the GLU, GLU+FRU and GLU+SUC treatment, respectively $(P<0.001)$, with no differences between treatments (time $x$ treatment, $P=0.757$ ).

Conclusion: Combined ingestion of glucose plus fructose does not further accelerate post-exercise muscle glycogen repletion in trained cyclists when ample carbohydrate is ingested. Combined ingestion of glucose (polymers) plus fructose or sucrose reduces gastrointestinal complaints when ingesting large amounts of carbohydrate. 


\section{INTRODUCTION}

From a quantitative point of view, muscle glycogen represents the most important fuel source during moderate- to high-intensity endurance type exercise $(31,38)$. Because of the direct relationship between fatigue and muscle glycogen depletion $(3,4)$, augmentation of post-exercise muscle glycogen repletion rates enhances performance recovery (42). Post-exercise muscle glycogen synthesis rates are largely determined by the amount of exogenous carbohydrate provided $(19,20,37,39)$. Previous research has shown that ingestion of $1.2 \mathrm{~g} \cdot \mathrm{kg}^{-1} \cdot \mathrm{h}^{-1}$ glucose (polymers), provided at frequent intervals (i.e. every $15-30 \mathrm{~min}$ ), allows for optimal post-exercise muscle glycogen synthesis rates $(1,6,10,17$, $18,20,36,37,39)$. Increasing glucose intake up to $1.6 \mathrm{~g} \cdot \mathrm{kg}^{-1} \cdot \mathrm{h}^{-1}$ does not seem to further augment post-exercise muscle glycogen storage (17).

The systemic availability of ingested carbohydrates may be limited by intestinal glucose absorption (22, 25). It has been suggested that the intestinal sodium-dependent glucose transporter 1 (SGLT1) becomes saturated when large amounts of glucose or glucose polymers are ingested $(22,25)$, which may explain why glucose ingestion at rates above $1.2 \mathrm{~g} \cdot \mathrm{kg}^{-1} \cdot \mathrm{h}^{-1}$ does not further stimulate muscle glycogen synthesis on average (17). Interestingly, the intestine contains a distinct class of carbohydrate transporters, Glucose Transporter 5 (GLUT5), which absorbs fructose and most likely fructose released during hydrolysis from the disaccharide sucrose $(13,15,33)$. More recently, other intestinal carbohydrate transporters have been implicated in glucose (GLUT2) and fructose (GLUT2, GLUT8, GLUT12) intestinal absorption $(14,29,32)$. Because of distinct transport routes for glucose and fructose, higher total intestinal carbohydrate absorption rates can be expected when glucose and fructose are co-ingested.

In agreement, combined glucose and fructose ingestion has been shown to enhance intestinal carbohydrate absorption $(34,35)$. In addition, combined ingestion of glucose and fructose increases exogenous carbohydrate oxidation rates during exercise compared to an equivalent amount of glucose only $(21,22,24,25)$. As exogenous carbohydrate oxidation is limited by intestinal carbohydrate absorption (16), we hypothesised that ingestion of multiple transportable carbohydrates represents a viable dietary strategy to further enhance total carbohydrate absorption and subsequent availability of these carbohydrates (11). Sucrose combines glucose and fructose monomers, and its hydrolysis is not rate limiting for intestinal absorption $(35,41)$. Although speculative, when SGLT1 becomes saturated, hydrolysis of sucrose may be inhibited (23). As such, it is unclear if sucrose represents an effective source of multiple carbohydrates when total glucose intake (from glucose and/or the hydrolysis of sucrose) is high.

The ingestion of multiple transportable carbohydrates during post-exercise recovery as a means to improve total carbohydrate availability and subsequently accelerate muscle glycogen repletion has not been investigated thoroughly. Recently, Wallis et al. (40) reported that glucose and glucose/fructose (2:1 ratio) solutions, ingested at a rate of $90 \mathrm{~g} \cdot \mathrm{h}^{-1}$, resulted in similar rates of muscle glycogen synthesis during $4 \mathrm{~h}$ of post-exercise recovery. However, the ingested amount of glucose in the glucose/fructose treatment $\left(60 \mathrm{~g} \cdot \mathrm{h}^{-1}\right.$, or $\sim 0.8 \mathrm{~g} \cdot \mathrm{kg}^{-1} \cdot \mathrm{h}^{-1}$ ) was below the recommended $1.2 \mathrm{~g} \cdot \mathrm{kg}^{-1} \cdot \mathrm{h}^{-1}$ required to maximize muscle glycogen synthesis rates, whereas in the glucose only treatment the optimal amount of $\sim 1,2$ $\mathrm{g} \cdot \mathrm{kg}^{-1} \cdot \mathrm{h}^{-1}$ was provided. Therefore, it could be speculated that the combined ingestion of glucose and 
fructose will only augment muscle glycogen synthesis rates when ample glucose is provided $\left(\geq 1.2 \mathrm{~g} \cdot \mathrm{kg}^{-}\right.$ $\left.{ }^{1} \cdot h^{-1}\right)$.

In the present study, we tested our hypothesis by subjecting 14 male cyclists to glycogen depletion exercise on 3 occasions, after which they ingested GLU (1.5 $\mathrm{g} \cdot \mathrm{kg}^{-1} \cdot \mathrm{h}^{-1}$ glucose), GLU+FRU (1.2 $\mathrm{g} \cdot \mathrm{kg}^{-1} \cdot \mathrm{h}^{-1}$ glucose $+0.3 \mathrm{~g} \cdot \mathrm{kg}^{-1} \cdot \mathrm{h}^{-1}$ fructose), or GLU+SUC $\left(0.9 \mathrm{~g} \cdot \mathrm{kg}^{-1} \cdot \mathrm{h}^{-1}\right.$ glucose $+0.6 \mathrm{~g} \cdot \mathrm{kg}^{-1} \cdot \mathrm{h}^{-1}$ sucrose) during a $5 \mathrm{~h}$ recovery period. Muscle biopsies were collected immediately, after 2 and $5 \mathrm{~h}$ of post-exercise recovery to assess muscle glycogen repletion rates. 


\section{METHODS}

\section{Subjects}

Fourteen well-trained male cyclists participated in this study (age: $28 \pm 6$ y, bodyweight: $77.1 \pm 7.2 \mathrm{~kg}$, body mass index: $23.1 \pm 1.6 \mathrm{~kg} \cdot \mathrm{m}^{-2}$, maximal workload capacity $\left.\left(W_{\text {MAX }}\right): 4.8 \pm 0.4 \mathrm{~W} \cdot \mathrm{kg}^{-1}\right)$. Subjects cycled at least $100 \mathrm{~km} \cdot \mathrm{wk}^{-1}$ and had a training history of $>3 \mathrm{y}$. Subjects were fully informed on the nature and possible risks of the experimental procedures, before their written informed consent was obtained. The study was approved by the Medical Ethical Committee of the Maastricht University Medical Centre, Maastricht, The Netherlands.

\section{Pretesting}

At least 1 week before the first experiment, Subjects performed an incremental exhaustive exercise test (27) on an electronically braked cycle ergometer (Lode Excalibur, Groningen, The Netherlands) to assess $W_{\text {MAX. }}$

\section{Diet and Activity before the Experiments}

All subjects received the same standardized dinner $\left(73 \mathrm{~kJ} \cdot \mathrm{kg}^{-1}\right.$ body weight, consisting of 55 energy\% (En\%) $\mathrm{CHO}, 27 \mathrm{En \%}$ fat, and $18 \mathrm{En \%}$ Protein) the evening before each test. All volunteers refrained from any sort of exhaustive physical labour and/or exercise and kept their diet as constant as possible $2 \mathrm{~d}$ before each experimental day. In addition, subjects filled in food intake and physical activity questionnaires for $2 \mathrm{~d}$ before the start of the first experiment, which were used to standardize food intake and physical activity before the second and third experimental day.

\section{Design}

Subjects performed 3 tests, in a randomized double-blind order, each separated by at least $1 \mathrm{wk}$. During each test, they were first subjected to a glycogen depletion protocol. Thereafter, subjects were studied for $5 \mathrm{~h}$ while ingesting one of three isocaloric carbohydrate mixtures: glucose only (GLU), glucose and fructose (GLU+FRU) or glucose and sucrose (GLU+SUC). During the $5 \mathrm{~h}$ post-exercise recovery period, subjects remained in supine rest. Beverages were provided every $30 \mathrm{~min}$, and muscle biopsies were taken immediately after exercise, $2 \mathrm{~h}$ after exercise, and at the end of the $5 \mathrm{~h}$ recovery period to assess muscle glycogen content.

\section{Experimental Protocol}

Subjects reported to the laboratory at 8:00 a.m. following an overnight fast. Muscle glycogen depletion was established by performing an intense exercise protocol on a cycle ergometer (26). This muscle glycogen depletion protocol started with a 10 min warm-up period at 50\% $W_{\text {MAx }}$ workload. Thereafter, subjects were instructed to cycle 2 min block periods at alternating workloads of $90 \%$ and $50 \% W_{\text {MAX }}$, respectively. This was continued until subjects were no longer able to complete the 2 min blocks at $90 \% W_{\text {MAX }}$. That moment was defined as the inability to maintain cycling speed at $60 \mathrm{rpm}$. At that moment, the high-intensity blocks were reduced to $80 \% W_{\text {MAx }}$. Again, subjects had to cycle until they were unable to complete a 2 min block at $80 \% W_{\text {MAX }}$, after which the high-intensity blocks were reduced to $70 \% W_{\text {MAX }}$. Subjects were allowed to stop when pedalling speed could not be maintained at $70 \%$ $W_{\text {MAX }}$. Water was provided ad libitum during the exercise protocol of the first test day, and the same amount of water was provided during the second and third test day. A fan was placed $1 \mathrm{~m}$ from the 
subjects to provide cooling and air circulation during the exercise protocol. After cessation of exercise, a muscle biopsy was taken from the vastus lateralis muscle. Thereafter, a catheter was inserted in an antecubital vein, a resting blood sample was taken and subjects received the first bolus of the test drink ( $t=0 \mathrm{~min}$ ). Subjects were observed for the following $5 \mathrm{~h}$ during which they received a beverage with a volume of $3.33 \mathrm{~mL} \cdot \mathrm{kg}^{-1}$ every $30 \mathrm{~min}$ until $t=270 \mathrm{~min}$. Blood samples were taken at $15 \mathrm{~min}$ intervals for the first $30 \mathrm{~min}$ of recovery and every $30 \mathrm{~min}$ thereafter until $t=300 \mathrm{~min}$. Immediately after obtaining the blood sample at $t=120 \mathrm{~min}$, a second muscle biopsy was taken and a third muscle biopsy was taken after acquiring the final blood sample at $t=300 \mathrm{~min}$.

\section{Questionnaires}

Subjects were asked to fill out a gastrointestinal (GI) distress questionnaire using a 4-point scale ( $1=$ not at all, 2 = a bit, 3 = considerable and 4 = very severe) immediately after exercise (before the first beverage was received) and every $30 \mathrm{~min}$ thereafter. This questionnaire was adapted from Jentjens et al. (20) and assessed the following complaints: nausea, feeling full, urge to throw up, bloated feeling, diarrhoea, and belching. None of the subjects reported any Gl problems before ingestion of the test beverages (immediately after exercise). Gl distress scores following drink ingestion are expressed as the accumulated score on all questions.

\section{Beverages}

Subjects received a beverage volume of $3.33 \mathrm{~mL} \cdot \mathrm{kg}^{-1}$ every $30 \mathrm{~min}$ during recovery to ensure a given dose of $1.5 \mathrm{~g} \cdot \mathrm{kg}^{-1} \cdot \mathrm{h}^{-1}$ total carbohydrates. The GLU drink provided $1.5 \mathrm{~g} \cdot \mathrm{kg}^{-1} \cdot \mathrm{h}^{-1}$ glucose $\left(0.9 \mathrm{~g} \cdot \mathrm{kg}^{-1} \cdot \mathrm{h}^{-1}\right.$ glucose $+0.6 \mathrm{~g} \cdot \mathrm{kg}^{-1} \cdot \mathrm{h}^{-1}$ maltodextrin), the GLU+FRU drink provided $1.2 \mathrm{~g} \cdot \mathrm{kg}^{-1} \cdot \mathrm{h}^{-1} \mathrm{glucose}\left(0.6 \mathrm{~g} \cdot \mathrm{kg}^{-1} \cdot \mathrm{h}^{-1}\right.$ glucose $+0.6 \mathrm{~g} \cdot \mathrm{kg}^{-1} \cdot \mathrm{h}^{-1}$ maltodextrin) $+0.3 \mathrm{~g} \cdot \mathrm{kg}^{-1} \cdot \mathrm{h}^{-1}$ fructose, and the GLU+SUC drink provided 0.9 $\mathrm{g} \cdot \mathrm{kg}^{-1} \cdot \mathrm{h}^{-1}$ glucose $\left(0.3 \mathrm{~g} \cdot \mathrm{kg}^{-1} \cdot \mathrm{h}^{-1}\right.$ glucose $+0.6 \mathrm{~g} \cdot \mathrm{kg}^{-1} \cdot \mathrm{h}^{-1}$ maltodextrin $)+0.57 \mathrm{~g} \cdot \mathrm{kg}^{-1} \cdot \mathrm{h}^{-1}$ sucrose. The slightly lower total amount of carbohydrates in the GLU+SUC drink was chosen to provide equimolar amounts of monosaccharides. The glucose and maltodextrin (from starch with a dextrose equivalent of 14) were obtained from Avebe Food Netherlands, Veendam; fructose from Azelis Netherlands B.V., Oosterhout; and sucrose from Van Gilse, Oud Gastel. To all drinks, $20 \mathrm{mmol} \cdot \mathrm{L}^{-1}$ sodium chloride and 3 $\mathrm{g}$ citric acid was added. Beverages were provided in a double-blind, randomized order.

\section{Muscle Biopsies}

Muscle biopsies were obtained from the middle region of the vastus lateralis ( $15 \mathrm{~cm}$ above the patella) and approximately $2 \mathrm{~cm}$ below the entry through the fascia using the percutaneous needle biopsy technique described by Bergström et al. (5). All 3 muscle samples on one experimental day were taken from the same leg, with separate incisions $\sim 1 \mathrm{~cm}$ apart and from distal to proximal direction. Muscle biopsies on the second test day were taken from the contralateral leg, and on the third experimental day biopsies were taken from the same leg as the first trial. All samples were carefully freed from any visible adipose tissue and blood, immediately frozen in liquid nitrogen, and stored at $-80^{\circ} \mathrm{C}$ until subsequent analyses.

\section{Plasma Analysis}

Blood samples $(8 \mathrm{~mL})$ were collected in EDTA-containing tubes and centrifuged at $1000 \mathrm{~g}$ and $4^{\circ} \mathrm{C}$ for $10 \mathrm{~min}$. Aliquots of plasma were frozen in liquid nitrogen and stored at $-80^{\circ} \mathrm{C}$ until analysis. Plasma glucose and lactate were analyzed with a COBAS-FARA semiautomatic analyzer (Roche). Plasma insulin 
concentrations were analyzed using commercially available kits (Elecsys Insulin assay, Roche, Ref: 12017547122).

\section{Muscle analysis}

Muscle tissue, $\sim 30 \mathrm{mg} w w$, was freeze-dried after which collagen, blood, and non-muscle fiber material were removed from the muscle fibers under a microscope. The isolated muscle fiber mass $(\sim 5-7 \mathrm{mg})$ was weighed, and $500 \mu \mathrm{L}$ of $1 \mathrm{M} \mathrm{HCl}$ was added. After heating for $3 \mathrm{~h}$ at $100^{\circ} \mathrm{C}$ to hydrolyze the glycogen to glycosyl units and cooling down to room temperature, $500 \mu \mathrm{L}$ of the solution was neutralised by adding $280 \mu \mathrm{L}$ of Tris- $\mathrm{KOH}$ (Tris $119 \mathrm{mM}, \mathrm{KOH} 2.14 \mathrm{M}$ ) and centrifuged at $1000 \mathrm{~g}$ and $4^{\circ} \mathrm{C}$ for $10 \mathrm{~min}$. Thereafter, $150 \mu \mathrm{L}$ of this solution was analysed for glucose concentration (Glucose HK CP A11A01667; ABX Pentra) with a COBAS FARA semiautomatic analyser (Roche).

\section{Statistics}

Plasma and muscle data are expressed as means $\pm S D$, and gastrointestinal distress scores are expressed as median and interquartile range. A sample size of 14 including a $20 \%$ dropout rate was calculated with a power of $80 \%$ and an alpha level of 0.05 to detect a $~ 25 \%$ difference in muscle glycogen repletion between treatments. A two-factor repeated-measures ANOVA with time and treatment as factors was used to compare differences between treatments over time. In case of significant F-ratios $(P<0.05)$, Bonferroni post hoc tests were applied to locate the differences. A Friedman test was used to compare $\mathrm{Gl}$ distress scores between treatments. In case of significant $\mathbf{X}^{2}$, post hoc analysis with Wilcoxon signed-rank was conducted with a Bonferroni correction applied. 


\section{RESULTS}

\section{Exercise protocol}

Subjects' maximal workload capacity, measured during the pretesting, averaged $372 \pm 29 \mathrm{~W}(4.8 \pm 0.4$ $\left.\mathrm{W} \cdot \mathrm{kg}^{-1}\right)$. Consequently, average workload settings in the depletion protocol were 186 $\pm 14,260 \pm 20$, $297 \pm 23$, and $334 \pm 26 \mathrm{~W}$ at $50 \%, 70 \%, 80 \%$, and $90 \% W_{\max }$, respectively. On average, subjects cycled a total of $19 \pm 7,21 \pm 8$, and $18 \pm 7$ high-intensity blocks, which resulted in a total cycling time of $89 \pm 27$, $93 \pm 33$, and $82 \pm 27 \mathrm{~min}$ in the GLU, GLU+FRU, and GLU+SUC experiments, respectively. Total cycling time did not differ significantly between experiments $(P=0.273)$.

\section{Plasma analysis}

Plasma glucose, lactate, and insulin concentrations during the $5 \mathrm{~h}$ recovery period are shown in Figure 4.1. Plasma glucose concentrations immediately post-exercise did not differ significantly between treatments $(P=0.304)$. Carbohydrate ingestion resulted in a rapid increase in plasma glucose concentration during the first 60 min of post-exercise recovery, after which concentrations declined to baseline levels, with no significant differences between treatments (treatment $x$ time, $P=0.096$ ). Plasma lactate concentrations immediately post-exercise did not differ significantly between treatments $(P=0.273)$. Plasma lactate concentrations declined during the first $30 \mathrm{~min}$ in all 3 treatments, after which concentrations remained stable in GLU, and increased within $60 \mathrm{~min}$ in the GLU+FRU and GLU+SUC treatments. During the rest of the recovery period, plasma lactate concentrations remained significantly elevated in GLU+FRU and GLU+SUC compared to GLU (treatment x time, $P=0.000$ ). Plasma insulin concentrations immediately post-exercise did not differ significantly between treatments $(P=0.757)$. In all experiments, plasma insulin concentrations increased during the first $180 \mathrm{~min}$ of post-exercise recovery, after which concentrations plateaued in the GLU+FRU and GLU+SUC treatments, and declined in the GLU treatment. Hence, the increase in plasma insulin concentration over time was significantly greater in GLU+FRU and GLU+SUC when compared to GLU (treatment x time, $P=0.006$ ). 

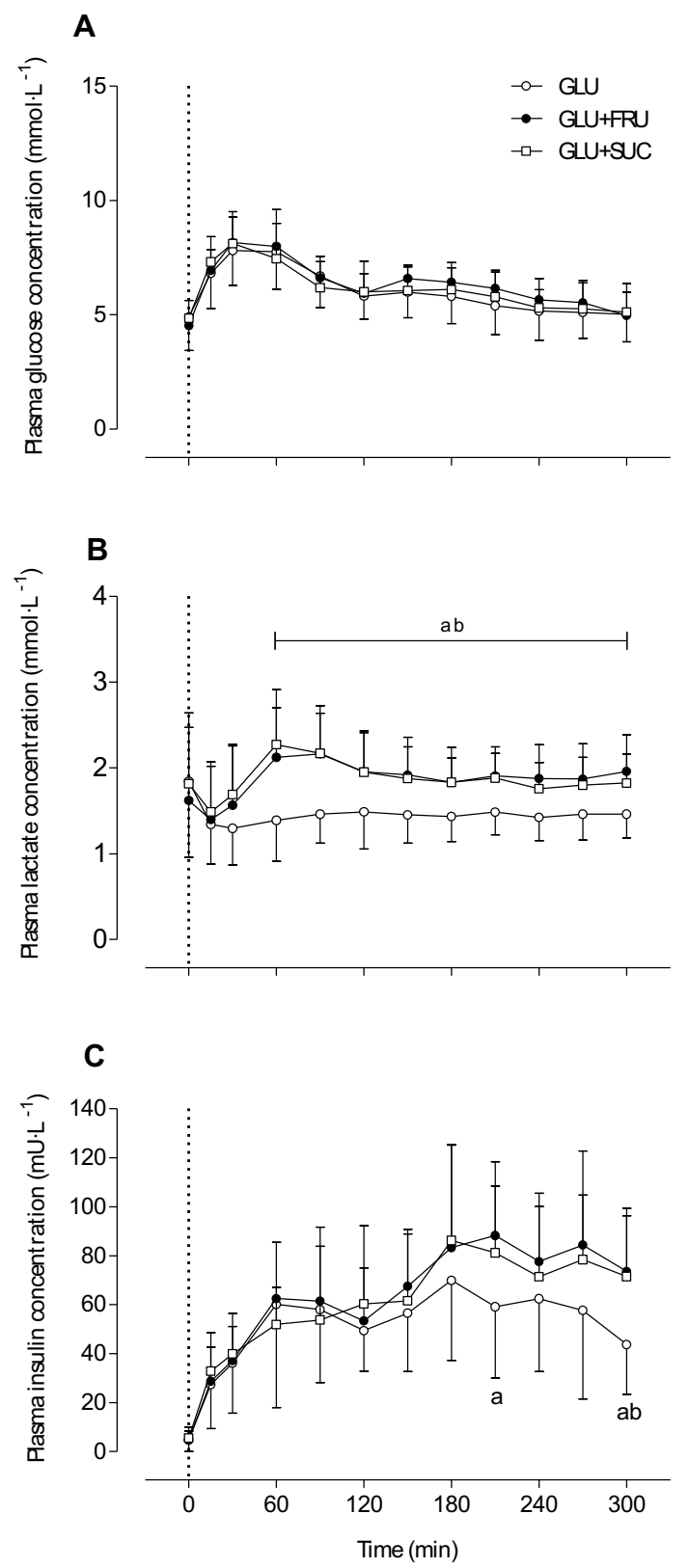

Figure 4.1. Plasma glucose (A), lactate (B), and insulin (C) concentrations during the $5 \mathrm{~h}$ recovery period. Values represent means $\pm S D ; n=14$. GLU: glucose; GLU+FRU: glucose+fructose; GLU+SUC: glucose+sucrose. ${ }^{a}$ GLU+FRU significantly different from GLU; ${ }^{b} \mathrm{GLU}+\mathrm{SUC}$ significantly different from GLU.

\section{Muscle analysis}

Muscle glycogen concentrations over time are shown in Figure 4.2. Post-exercise muscle glycogen concentrations increased from $207 \pm 112,219 \pm 107$, and $236 \pm 118 \mathrm{mmol} \cdot \mathrm{kg}^{-1}$ dry weight to $261 \pm 98$, $289 \pm 130$, and $315 \pm 103 \mathrm{mmol} \cdot \mathrm{kg}^{-1}$ dry weight in the GLU, GLU+FRU, and GLU+SUC experiments, respectively, with no significant differences between treatments (time $x$ treatment, $P=0.757$ ). 


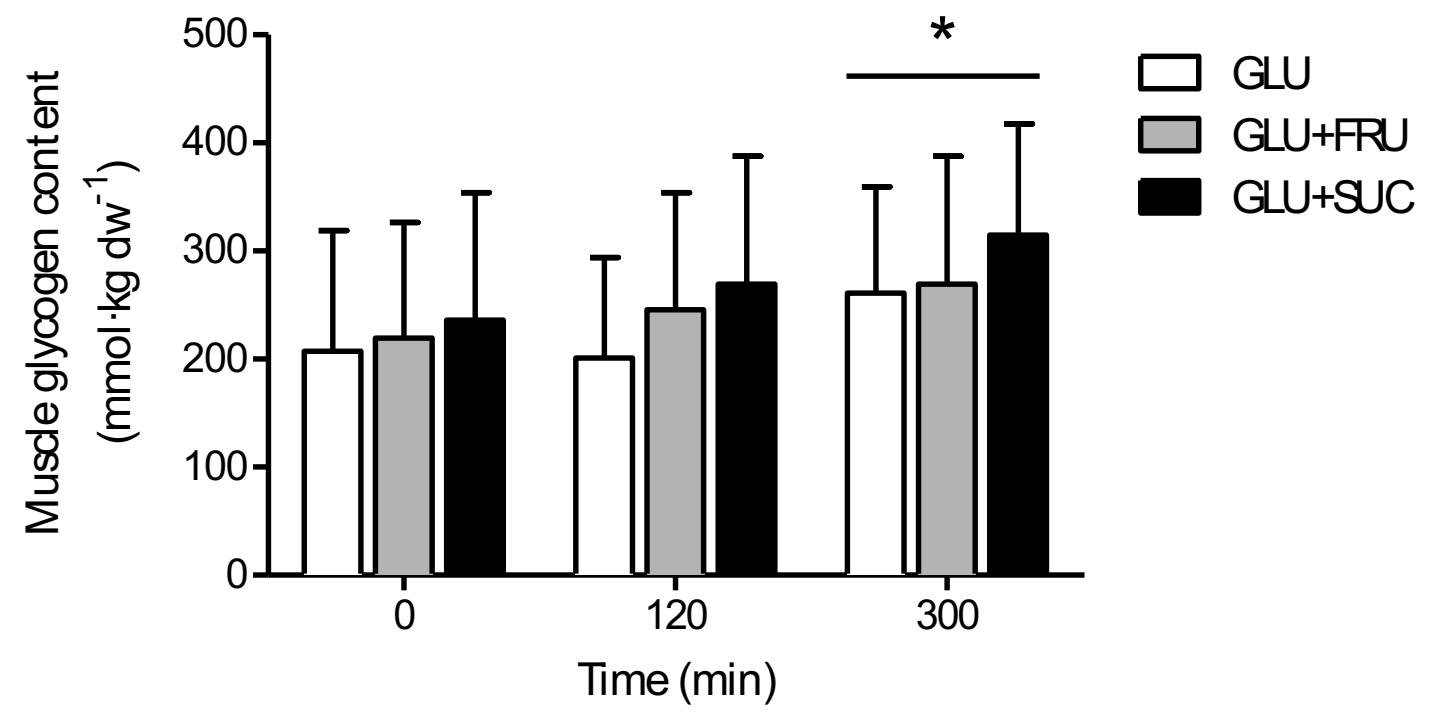

Figure 4.2. Muscle glycogen content during the $5 \mathrm{~h}$ recovery period. Values represent means $\pm S D ; n=14$. GLU: glucose; GLU+FRU: glucose+fructose; GLU+SUC: glucose+sucrose. * Significantly different from $t=0 \mathrm{~min}$.

\section{Drink ingestion and gastrointestinal distress}

In total, $96 \pm 7,100 \pm 0$, and $99 \pm 3 \%$ of the total volume of the test drink $(2.6 \pm 0.1 \mathrm{~L})$ was ingested in the GLU, GLU+FRU, and GLU+SUC treatments, respectively. Total Gl distress scores were 78 (68-85), 68 (63-78), and 70 (63-86) in GLU, GLU+FRU, and GLU+SUC treatments, respectively, and were significantly higher in the GLU compared to the GLU+FRU treatment ( $n=11, P=0.021)$. GI distress scores at the end of the $5 \mathrm{~h}$ recovery period ( $t=300 \mathrm{~min}$ ) were 11 (9-12), 8 (7-8) and 8 (7-11) in GLU, GLU+FRU, and GLU+SUC treatments, respectively, and significantly higher in the GLU treatment compared to the GLU+FRU or GLU+SUC treatments $(n=11, P<0.05)$. 


\section{DISCUSSION}

The present study shows that the combined ingestion of glucose and fructose $\left(1.2 \mathrm{~g} \cdot \mathrm{kg}^{-1} \cdot \mathrm{h}^{-1}\right.$ glucose plus $0.3 \mathrm{~g} \cdot \mathrm{kg}^{-1} \cdot \mathrm{h}^{-1}$ fructose or $0.9 \mathrm{~g} \cdot \mathrm{kg}^{-1} \cdot \mathrm{h}^{-1}$ glucose $+0.6 \mathrm{~g} \cdot \mathrm{kg}^{-1} \cdot \mathrm{h}^{-1}$ sucrose) does not further accelerate post-exercise muscle glycogen synthesis when compared to the ingestion of $1.5 \mathrm{~g} \cdot \mathrm{kg}^{-1} \cdot \mathrm{h}^{-1}$ glucose only. Combined ingestion of glucose plus fructose or sucrose resulted in less gastrointestinal complaints when compared with the ingestion of glucose only.

Previous work indicates that the ingestion of glucose at a rate of $1.2 \mathrm{~g} \cdot \mathrm{kg}^{-1} \cdot \mathrm{h}^{-1}$, provided at frequent intervals (i.e., every 15-30 min), is required to maximize muscle glycogen synthesis rates $(1,6,10,17$, $18,20,36,37,39)$. Increasing glucose intake up to $1.6 \mathrm{~g} \cdot \mathrm{kg}^{-1} \cdot \mathrm{h}^{-1}$ does not further augment post-exercise muscle glycogen storage (17). However, it has been postulated that the ingestion of such large amounts of glucose may saturate the intestinal glucose transporter $\operatorname{SGLT1}(22,25)$, thereby limiting intestinal carbohydrate absorption and its subsequent availability for muscle glycogen synthesis. Therefore, we hypothesised that the combined ingestion of multiple transportable carbohydrates (i.e. carbohydrates which utilize different transporters for intestinal uptake) would represent an effective strategy to augment total intestinal carbohydrate absorption rates and subsequent muscle glycogen synthesis rates when compared to the intake of an isocaloric amount of glucose only.

The exercise protocol in our study resulted in post-exercise muscle glycogen concentrations that did not significantly differ between treatments (i.e., $207 \pm 112,219 \pm 107$ and $236 \pm 118 \mathrm{mmol} \cdot \mathrm{kg}^{-1} \mathrm{dry}$ weight in the GLU, GLU+FRU and GLU+SUC treatment, respectively). Since previous studies have reported pre-exercise muscle glycogen levels in athletes to range between 500 and $600 \mathrm{mmol} . \mathrm{kg}^{-1}$ dry weight $(7,12)$, our exercise protocol resulted in a substantial reduction in muscle glycogen content. To replenish muscle glycogen stores, we provided subjects with $1.5 \mathrm{~g} \cdot \mathrm{kg}^{-1} \cdot \mathrm{h}^{-1}$ carbohydrate during the $5 \mathrm{~h}$ recovery period following exercise, provided as either glucose only $\left(1.5 \mathrm{~g}^{\mathrm{kg}} \mathrm{kg}^{-1} \cdot \mathrm{h}^{-1}\right)$, glucose+fructose $\left(1.2 \mathrm{~g} \cdot \mathrm{kg}^{-1} \cdot \mathrm{h}^{-1}\right.$ glucose $\left.+0.3 \mathrm{~g} \cdot \mathrm{kg}^{-1} \cdot \mathrm{h}^{-1}\right)$, or glucose +sucrose $\left(0.9 \mathrm{~g} \cdot \mathrm{kg}^{-1} \cdot \mathrm{h}^{-1}\right.$ glucose $\left.+0.57 \mathrm{~g} \cdot \mathrm{kg}^{-1} \cdot \mathrm{h}^{-1}\right)$. The ingestion of GLU resulted in substantial higher total $\mathrm{Gl}$ distress when compared to the ingestion of GLU+FRU $(P<0.021)$. The lower total $G$ distress with glucose and fructose co-ingestion seems to suggest that this treatment led to less carbohydrate accumulation in the GI tract, possibly caused by more rapid intestinal carbohydrate absorption when compared with the ingestion of glucose only.

In contrast to our hypothesis, fructose co-ingestion did not further increase muscle glycogen concentrations over the $5 \mathrm{~h}$ post-exercise recovery period $\left(261 \pm 98,289 \pm 130\right.$, and $315 \pm 103 \mathrm{mmol} \cdot \mathrm{kg}^{-}$ ${ }^{1}$ dry weight after $5 \mathrm{~h}$ of recovery in the GLU, GLU+FRU, and GLU+SUC treatment, respectively). The proposed increase in carbohydrate absorption rates in the GLU+FRU and GLU+SUC treatments did not seem to translate to greater glycogen repletion. After ingestion and intestinal absorption, fructose is metabolised in the liver and subsequently released in the systemic circulation as lactate for oxidation in extrahepatic tissues (8), or converted to glucose via gluconeogenesis, which is mainly released or used for liver glycogen synthesis depending on the need to maintain plasma glucose levels (28). We observed no significant differences in systemic glucose availability, but elevated plasma lactate concentrations were observed following both fructose or sucrose co-ingestion. These data indicate that despite high total glucose intake, the hydrolysis of sucrose does not appear to be inhibited. Therefore, fructose co-ingestion with glucose seems to be effectively absorbed in the intestine, transported to the liver where it is either converted to liver glycogen or metabolised to lactate, the latter of which is 
released in the circulation and subsequently oxidized. In addition, fructose co-ingestion resulted in significantly higher plasma insulin concentration compared to the ingestion of glucose only. However, higher levels of plasma insulin may not further enhance muscle glycogen synthesis rates when ample carbohydrates are provided $(19,20)$.

Despite the fact that fructose or sucrose co-ingestion with glucose did not significantly augment postexercise muscle glycogen repletion, we did observe some benefits when multiple transportable carbohydrates were ingested. As also shown from the Gl questionnaire data, we observed substantially less $\mathrm{Gl}$ issues when co-ingesting fructose or sucrose when compared to the ingestion of the same amount of glucose only. Especially at these high carbohydrate ingestion rates $\left(>1.2 \mathrm{~g} \cdot \mathrm{kg}^{-1} \cdot \mathrm{h}^{-1}\right), \mathrm{Gl}$ issues become frequent, even in these trained athletes. Ingestion of such large amounts of glucose postexercise have been shown to induce substantial GI distress in many athletes (19). Our results indicate substantial lower levels of GI distress with fructose or sucrose co-ingestion compared to glucose only. Therefore, even though it does not accelerate muscle glycogen resynthesis, fructose or sucrose coingestion is likely preferred to reduce gastrointestinal discomfort and to facilitate the capacity to achieve the recommendations for post-exercise carbohydrate intake. In addition, fructose co-ingestion may be beneficial to enhance liver glycogen repletion. Liver glycogen is essential to prevent hypoglycaemia during exercise (30), and positively associated with exercise capacity (9). Previous work has shown that fructose ingestion following exercise is preferentially used for liver glycogen repletion, resulting in greater liver glycogen repletion rates when compared the ingestion of glucose $(2,30)$. This may be of particular relevance for those athletes that need to compete twice daily and where liver glycogen availability represents the limiting factor for subsequent performance (9). However, because of the obvious methodological restrictions when assessing liver glycogen content, we did not address this issue in the present study design.

We conclude that fructose or sucrose co-ingestion do not further accelerate post-exercise muscle glycogen synthesis when ample amounts of carbohydrate are ingested $\left(\geq 1.2 \mathrm{~g} \cdot \mathrm{kg}^{-1} \cdot \mathrm{h}^{-1}\right)$. When ingesting large amounts of carbohydrate during recovery from exhaustive exercise, co-ingestion of fructose or sucrose with glucose will lower gastrointestinal discomfort.

\section{ACKNOWLEDGEMENTS}

We gratefully acknowledge the assistance of Janneau van Kranenburg and the enthusiastic support of the volunteers who participated in these experiments. This project was partly funded by a research grant from Kenniscentrum Suiker \& Voeding, Utrecht, the Netherlands and the Sugar Nutrition UK., London, United Kingdom. The authors report no conflict of interest. The results of the present study do not constitute endorsement by the American College of Sports Medicine. 


\section{REFERENCES}

1. Beelen M, Kranenburg JV, Senden JM, Kuipers H, Loon LJ. Impact of caffeine and protein on postexercise muscle glycogen synthesis. Medicine \& Science in Sports \& Exercise 2012;44(4):692-700.

2. Bergstrom J, Furst P, Gallyas F, et al. Aspects of fructose metabolism in normal man. Acta Med Scand Suppl 1972;542:57-64.

3. Bergstrom J, Hermansen L, Hultman E, Saltin B. Diet, muscle glycogen and physical performance. Acta Physiologica Scandinavica 1967;71(2):140-50.

4. Bergstrom J, Hultman E. A study of the glycogen metabolism during exercise in man. Scand. J. Clin. Lab. Invest. 1967;19(3):218-28.

5. Bergstrom J. Percutaneous needle biopsy of skeletal muscle in physiological and clinical research. Scand. J. Clin. Lab. Invest. 1975;35(7):609-16.

6. Blom PC, Hostmark AT, Vaage O, Kardel KR, Maehlum S. Effect of different post-exercise sugar diets on the rate of muscle glycogen synthesis. Medicine \& Science in Sports \& Exercise 1987;19(5):491-6.

7. Bosch AN, Weltan SM, Dennis SC, Noakes TD. Fuel substrate turnover and oxidation and glycogen sparing with carbohydrate ingestion in non-carbohydrate-loaded cyclists. Pflugers Arch 1996;432(6):1003-10.

8. Brooks GA, Brauner KE, Cassens RG. Glycogen synthesis and metabolism of lactic acid after exercise. Am J Physiol 1973;224(5):1162-6.

9. Casey A, Mann R, Banister K, et al. Effect of carbohydrate ingestion on glycogen resynthesis in human liver and skeletal muscle, measured by (13)C MRS. Am J Physiol Endocrinol Metab 2000;278(1):E65-75.

10. Casey A, Short AH, Hultman E, Greenhaff PL. Glycogen resynthesis in human muscle fibre types following exercise-induced glycogen depletion. J Physiol 1995;483 ( Pt 1):265-71.

11. Cermak NM, van Loon LJC. The use of carbohydrates during exercise as an ergogenic aid. Sports Med 2013;43(11):1139-55.

12. Costill DL, Sherman WM, Fink WJ, Maresh C, Witten M, Miller JM. The role of dietary carbohydrates in muscle glycogen resynthesis after strenuous running. Am J Clin Nutr 1981;34(9):1831-6.

13. Davidson RE, Leese HJ. Sucrose absorption by the rat small intestine in vivo and in vitro. J Physiol 1977;267(1):237-48.

14. DeBosch BJ, Chi M, Moley KH. Glucose transporter 8 (GLUT8) regulates enterocyte fructose transport and global mammalian fructose utilization. Endocrinology 2012;153(9):4181-91.

15. Ferraris RP, Diamond J. Regulation of intestinal sugar transport. Physiol Rev 1997;77(1):257302.

16. Hawley JA, Bosch AN, Weltan SM, Dennis SC, Noakes TD. Glucose kinetics during prolonged exercise in euglycaemic and hyperglycaemic subjects. Pflugers Arch 1994;426(5):378-86.

17. Howarth KR, Moreau NA, Phillips SM, Gibala MJ. Coingestion of protein with carbohydrate during recovery from endurance exercise stimulates skeletal muscle protein synthesis in humans. J Appl Physiol (1985) 2009;106(4):1394-402.

18. Ivy JL, Lee MC, Brozinick JTJ, Reed MJ. Muscle glycogen storage after different amounts of 
carbohydrate ingestion. J Appl Physiol (1985) 1988;65(5):2018-23.

19. Jentjens $R$, Jeukendrup A. Determinants of post-exercise glycogen synthesis during short-term recovery. Sports Med 2003;33(2):117-44.

20. Jentjens RL, van Loon LJ, Mann CH, Wagenmakers AJ, Jeukendrup AE. Addition of protein and amino acids to carbohydrates does not enhance postexercise muscle glycogen synthesis. J Appl Physiol (1985) 2001;91(2):839-46.

21. Jentjens RLPG, Achten J, Jeukendrup AE. High oxidation rates from combined carbohydrates ingested during exercise. Medicine \& Science in Sports \& Exercise 2004;36(9):1551-8.

22. Jentjens RLPG, Moseley L, Waring RH, Harding LK, Jeukendrup AE. Oxidation of combined ingestion of glucose and fructose during exercise. J Appl Physiol (1985) 2004;96(4):1277-84.

23. Jentjens RLPG, SHAW C, Birtles T, Waring RH, Harding LK, Jeukendrup AE. Oxidation of combined ingestion of glucose and sucrose during exercise. Metabolism 2005;54(5):610-8.

24. Jentjens RLPG, Venables MC, Jeukendrup AE. Oxidation of exogenous glucose, sucrose, and maltose during prolonged cycling exercise. J Appl Physiol (1985) 2004;96(4):1285-91.

25. Jeukendrup AE. Carbohydrate and exercise performance: the role of multiple transportable carbohydrates. Curr Opin Clin Nutr Metab Care 2010;13(4):452-7.

26. Kuipers H, Saris WH, Brouns F, Keizer HA, Bosch ten C. Glycogen synthesis during exercise and rest with carbohydrate feeding in males and females. Int J Sports Med 1989;10 Suppl 1:S63-7.

27. Kuipers H, Verstappen FT, Keizer HA, Geurten P, van Kranenburg G. Variability of aerobic performance in the laboratory and its physiologic correlates. Int J Sports Med 1985;6(4):197201.

28. Laughlin MR. Normal roles for dietary fructose in carbohydrate metabolism. Nutrients 2014;6(8):3117-29.

29. Leturque A, Brot-Laroche E, Le Gall M, Stolarczyk E, Tobin V. The role of GLUT2 in dietary sugar handling. J Physiol Biochem 2005;61(4):529-37.

30. Nilsson LH, Hultman E. Liver and muscle glycogen in man after glucose and fructose infusion. Scand. J. Clin. Lab. Invest. 1974;33(1):5-10.

31. Romijn JA, Coyle EF, Sidossis LS, et al. Regulation of endogenous fat and carbohydrate metabolism in relation to exercise intensity and duration. Am J Physiol 1993;265(3 Pt 1):E38091.

32. Rowlands DS, Houltham S, Musa-Veloso K, Brown F, Paulionis L, Bailey D. Fructose-Glucose Composite Carbohydrates and Endurance Performance: Critical Review and Future Perspectives. Sports Medicine 2015;:1-16.

33. Sandle GI, Lobley RW, Warwick R, Holmes R. Monosaccharide absorption and water secretion during disaccharide perfusion of the human jejunum. Digestion 1983;26(2):53-60.

34. Shi X, Schedl HP, Summers RM, et al. Fructose transport mechanisms in humans. Gastroenterology 1997;113(4):1171-9.

35. Shi X, Summers RW, Schedl HP, Flanagan SW, Chang R, Gisolfi CV. Effects of carbohydrate type and concentration and solution osmolality on water absorption. Medicine \& Science in Sports \& Exercise 1995;27(12):1607-15.

36. Tarnopolsky MA, Bosman M, Macdonald JR, Vandeputte D, Martin J, Roy BD. Postexercise protein-carbohydrate and carbohydrate supplements increase muscle glycogen in men and women. J Appl Physiol (1985) 1997;83(6):1877-83. 
37. van Hall G, Shirreffs SM, Calbet JA. Muscle glycogen resynthesis during recovery from cycle exercise: no effect of additional protein ingestion. J Appl Physiol (1985) 2000;88(5):1631-6.

38. van Loon LJ, Greenhaff PL, Constantin-Teodosiu D, Saris WH, Wagenmakers AJ. The effects of increasing exercise intensity on muscle fuel utilisation in humans. J Physiol 2001;536(Pt 1):295304.

39. van Loon LJ, Saris WH, Kruijshoop M, Wagenmakers AJ. Maximizing postexercise muscle glycogen synthesis: carbohydrate supplementation and the application of amino acid or protein hydrolysate mixtures. Am J Clin Nutr 2000;72(1):106-11.

40. Wallis GA, Hulston CJ, Mann CH, Roper HP, Tipton KD, Jeukendrup AE. Postexercise muscle glycogen synthesis with combined glucose and fructose ingestion. Medicine \& Science in Sports \& Exercise 2008;40(10):1789-94.

41. Wallis GA, Wittekind $A$. Is there a specific role for sucrose in sports and exercise performance? Int J Sport Nutr Exerc Metab 2013;23(6):571-83.

42. Williams MB, Raven PB, Fogt $\mathrm{DL}$, Ivy JL. Effects of recovery beverages on glycogen restoration and endurance exercise performance. J Strength Cond Res 2003;17(1):12-9. 



\section{Chapter 5}

\section{Dietary protein intake and distribution patterns of well-trained Dutch athletes}

Jenna B. Gillen; Jorn Trommelen; Floris C. Wardenaar; Naomi Y.J. Brinkmans; Joline J. Versteegen; Kristin L. Jonvik; Christoph Kapp; Jeanne de Vries; Joost J.G.C. van den Borne; Martin J. Gibala; Luc J.C. van Loon 


\section{ABSTRACT}

Background: Dietary protein intake should be optimized in all athletes to ensure proper recovery and enhance the skeletal muscle adaptive response to exercise training. In addition to total protein intake, the use of specific protein-containing food sources and the distribution of protein throughout the day are relevant for optimizing protein intake in athletes.

Purpose: To assess the daily intake and distribution of various protein-containing food sources in a large cohort of strength, endurance and team-sport athletes.

Methods: Well-trained male $(n=327)$ and female $(n=226)$ athletes completed multiple web-based $24-h$ dietary recalls over a 2-4 wk period. Total energy intake, the contribution of animal- and plant-based proteins to daily protein intake, and protein intake at six eating moments were determined.

Results: Daily protein intake averaged $108 \pm 33$ and $90 \pm 24 \mathrm{~g}$ in men and women, respectively, which corresponded to relative intakes of $1.5 \pm 0.4$ and $1.4 \pm 0.4 \mathrm{~g}^{\mathrm{kg}}{ }^{-1}$. Dietary protein intake was correlated with total energy intake in strength $(r=0.71, p<0.001)$, endurance $(r=0.79, p<0.001)$ and team-sport $(r=0.77, p<0.001)$ athletes. Animal and plant-based sources of protein intake was $57 \%$ and $43 \%$, respectively. The distribution of protein intake was 19\% (19 $\pm 8 \mathrm{~g})$ at breakfast, $24 \%(25 \pm 13 \mathrm{~g})$ at lunch and $38 \%(38 \pm 15 \mathrm{~g})$ at dinner. Protein intake was below the recommended $20 \mathrm{~g}$ for $58 \%$ of athletes at breakfast, $36 \%$ at lunch and $8 \%$ at dinner.

Conclusion: Athletes habitually consume $>1.2 \mathrm{~g}$ protein $\cdot \mathrm{kg}^{-1} \cdot \mathrm{d}^{-1}$, but the distribution throughout the day may be suboptimal to maximize the skeletal muscle adaptive response to training. 


\section{INTRODUCTION}

Ingestion of adequate dietary protein is a fundamental consideration to ensure proper recovery from the physiological stress of prolonged exercise training. Dietary protein promotes resistance traininginduced gains in muscle mass and strength [1, 2]. Although less recognized, dietary protein supplementation may also facilitate optimal recovery from strenuous endurance-type exercise training and support skeletal muscle repair and remodeling [3, 4]. Consequently, protein intake should be optimized in all athletes to enhance the skeletal muscle adaptive response to exercise training, improve muscle recovery, increase exercise training efficiency and, as such, maximize performance capacity. The current recommended daily allowance (RDA) for protein is $0.8 \mathrm{~g} \cdot \mathrm{kg}^{-1} \cdot \mathrm{d}^{-1}[5]$. This amount is deemed sufficient for everyone, including athletes [5], but it has been proposed that athletes involved in strenuous exercise training require more dietary protein than their sedentary counterparts [6,7]. Dietary protein intake recommendations for athletes has been up to two fold higher than the RDA, with suggestions of $1.2-1.6$ [6], $1.2-1.7$ [8] and most recently, $1.3-1.8 \mathrm{~g} \cdot \mathrm{kg}^{-1} \cdot \mathrm{d}^{-1}$ [9]. The protein content of a healthy diet typically ranges between 15-25 EN\% however [10], suggesting that protein intake is strongly determined by total energy intake. Given the greater energy expenditure and energy intake in athletes [11], it seems obvious that dietary protein consumption is well above the recommended guidelines.

A number of food sources contribute to daily protein intake, all of which differ in amino acid composition and rates of digestion and absorption [12]. Though animal based proteins are considered to have greater anabolic properties than plant-based proteins $[13,14]$, a substantial part of daily protein intake is derived from plant-based food sources [12]. There are currently no data quantifying the contribution of different food sources to total protein intake in athletes. Based upon the proposed greater protein consumption in active athletes, we questioned what specific food sources contribute to the daily protein intake in various athlete groups.

Further to protein quantity and quality, the daily distribution of ingested protein influences the extent of physiological remodeling. A single $20-25 \mathrm{~g}$ bolus of high-quality protein maximally stimulates rates of muscle protein synthesis [15-17]. For this reason, consuming 4-5 evenly spaced feedings containing $20 \mathrm{~g}$ of high quality protein throughout the day is considered optimal for maximizing muscle protein synthesis [9, 18, 19]. Findings from Erdman et al. [20] indicate that male and female elite athletes consume only three daily meals containing $\geq 20 \mathrm{~g}$ of protein, with the highest quantities skewed towards the evening meal. To gain further insight into protein intake distribution, we sought to characterize the daily consumption patterns of various protein-containing food sources in a large cohort of well-trained athletes.

Information on the quantity and timing of specific dietary protein sources among athletes would yield valuable insight into patterns of protein consumption and may serve to encourage recommendations beyond total daily protein intake. However, data characterizing the consumption patterns of specific protein containing food sources in athletes are limited. Therefore, the aim of the present work was to comprehensively examine the daily intake and distribution of various protein containing food sources in a large cohort of well-trained athletes. We hypothesized that habitual protein intake is closely related to daily energy intake, resulting in protein consumption well above the recommended guidelines. We 
further hypothesized that plant-based proteins represent a substantial component of daily protein intake, and that the daily distribution of dietary protein intake is suboptimal in athletes. 


\section{METHODS}

\section{Subjects and Ethics Approval}

A total of 553 Dutch elite athletes took part in the study (Table 5.1). Participants were between 12-62 $y$ and performed $>9$ hours of exercise per week. All athletes had either, 1) held an elite athlete status of the Dutch Olympic Committee (NOC*NSF); 2) participated in a European or World Championship; or 3) proved to be top level in their discipline on a national level. Based on their particular discipline, participants were classified into one of three sport categories: 1) endurance; 2) team-sports; or 3) strength and/or sprint sports. A detailed breakdown of all disciplines within each sport category is provided in Table 5.2. All participants provided written informed consent. The survey was conducted according to the Declaration of Helsinki and was approved by the Medical Ethics Committee of Wageningen University.

\section{Experimental Protocol}

Data were collected as part of the Dutch Sport Nutrition and Supplement Study (DSSS) that was performed between February 2012 and June 2015. Following inclusion, participants were asked to complete three unannounced web-based 24-h dietary recalls and dietary supplement questionnaires during the conditioning phase of their training program. Data collection days were scheduled over a 2-4 week period and were at least 4 days apart. Collection days were selected to include two weekdays and one weekend for each participant. If the 24-hour recall and questionnaires were not completed within 36 hours, collection was rescheduled. Overall, athletes were given a maximum of four opportunities to deliver three 24-hour recalls and questionnaires.

\section{4-hour dietary recalls}

The 24-hour recalls were collected using 'Compl-eat ${ }^{\top \mathrm{M}}$ ', a web-based program that guides participants to accurately report food and drinks consumed the previous day. Compl-eat ${ }^{\mathrm{TM}}$ is based on the five-step multiple-pass method, a validated technique to increase accuracy of 24-h dietary recalls [21]. The program included a wide selection of foods commonly consumed in a Dutch food pattern (Stichting NEVO, 2010), but did not include dietary supplements or sport nutrition products. Protein intakes using this dietary recall method have been validated against nitrogen excretions [22], however comparisons to weighed food records have not been made. Details regarding participant data entry into Compleat ${ }^{\mathrm{TM}}$ is reported elsewhere [22]. Trained dietitians assessed all dietary recalls for completeness, unusual portion sizes, and possible missing food groups often consumed at main meals. Where appropriate, the participants were asked for further information.

\section{Questionnaires}

Web-based questionnaires regarding training load (minutes of exercise per day) and use of nutritional supplements were collected on three occasions in conjunction with the 24-h dietary recalls. Questionnaires were collected using the 'vitality portal' as reported elsewhere [22]. Briefly, participants were asked to specify any nutritional supplements consumed. A list of over 3400 products from the Dutch Database for Dietary Supplements (NES) was provided to aid the participants (RIVM, 2015). If a product consumed was not on the list, researchers obtained information from the nutritional label provided by the manufacturers. 


\section{Determination of protein intake from 24-h dietary recalls}

For each collection day, dietary energy (MJ) and protein ( $\left.\mathrm{g}, \mathrm{g} \cdot \mathrm{kg}^{-1}, \% \mathrm{En}\right)$ intake were determined using the Dutch Food Composition Database (Stichting NEVO, 2010). The contribution of animal and plantbased sources to dietary protein intake ( $\mathrm{g}$ ) were determined and expressed as a percentage of total protein intake. Daily protein intake was categorized into six eating moments: breakfast, morning snack, lunch, afternoon snack, dinner and evening snack. An average of all collection days was determined for each participant.

\section{Determination of protein supplementation among athletes}

Protein intake (g) from nutritional supplement questionnaires was determined for each participant. "Protein supplement-users" were defined as athletes consuming $\geq 10 \mathrm{~g}$ of protein $\mathrm{d}^{-1}$ from supplements. The contribution of dietary protein $\left(\mathrm{g} \cdot \mathrm{d}^{-1}, \mathrm{~g} \cdot \mathrm{kg}^{-1} \cdot \mathrm{d}^{-1}\right)$ and supplemental protein $\left(\mathrm{g} \cdot \mathrm{d}^{-1}, \mathrm{~g} \cdot \mathrm{kg}^{-}\right.$ $\left.{ }^{1} \cdot d^{-1}\right)$ was calculated for "supplement-users". Dietary protein intake $\left(g \cdot d^{-1}, g \cdot \mathrm{kg}^{-1} \cdot \mathrm{d}^{-1}\right)$ was calculated for "non-supplement users".

\section{Statistical analysis}

Data analyses were performed using SPSS Statistics (version 21). Data are presented as mean \pm standard deviation or as a percentage. Pearson's product-moment correlation coefficient was used to calculate the relationship between daily energy and protein intake. 


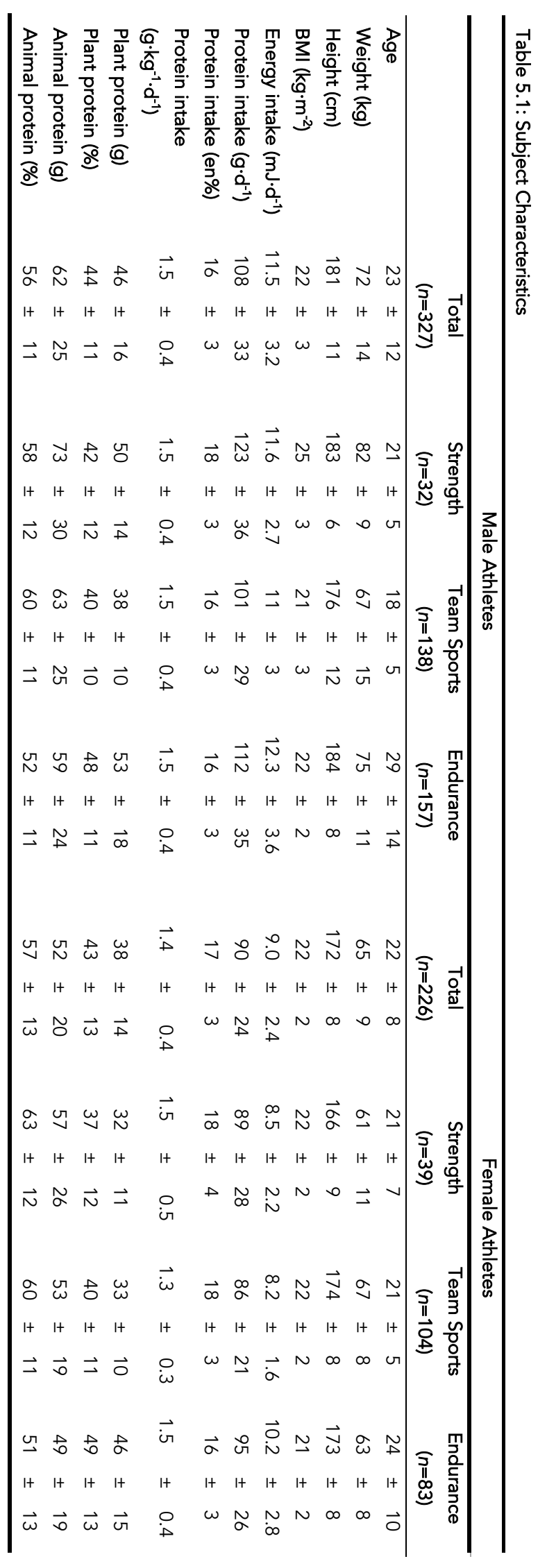




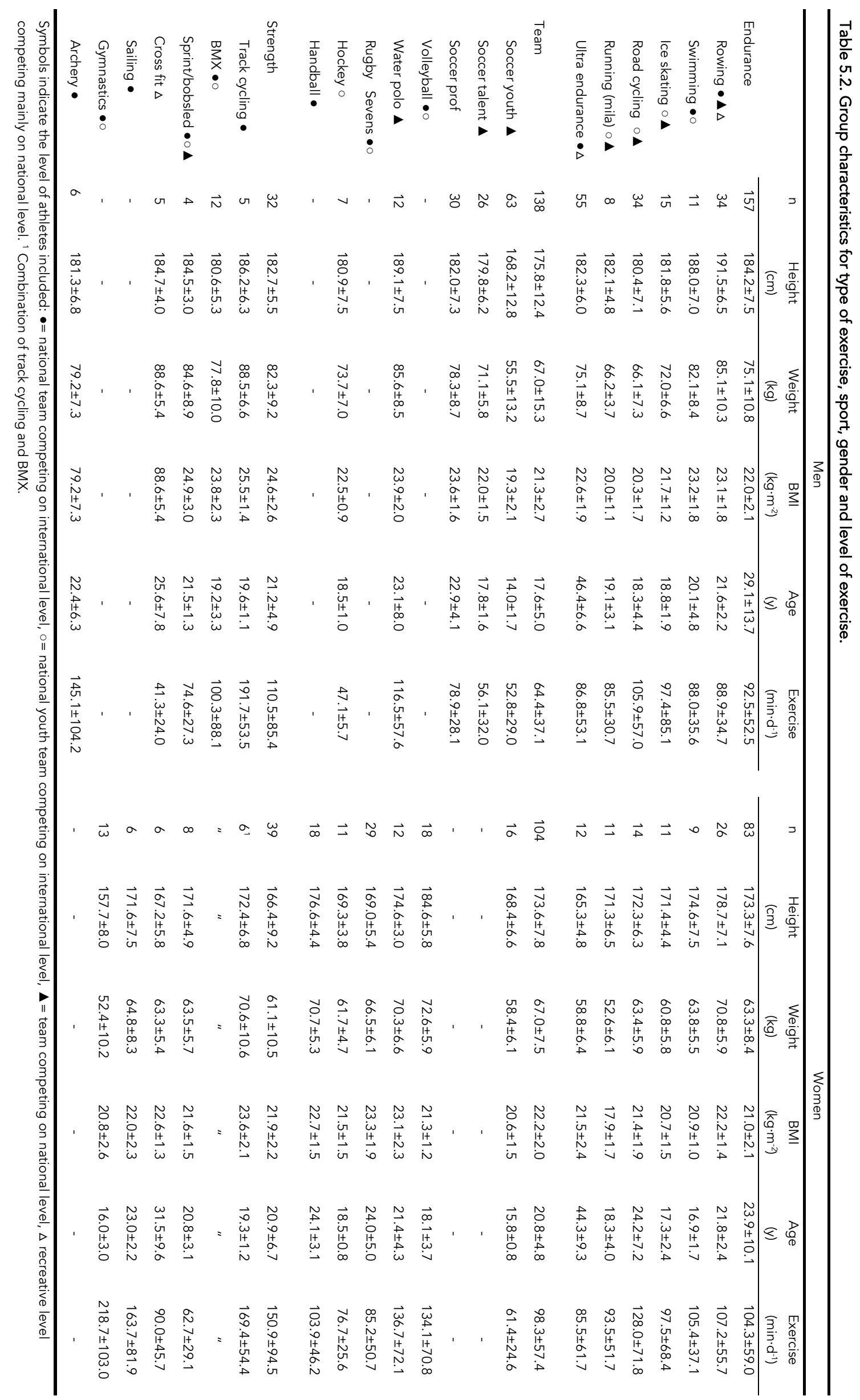




\section{RESULTS}

\section{Athletes' Characteristics}

A total of 553 athletes ( $n=327$ male; $n=226$ female) were classified as strength ( $n=71$, team-sports $(n=242)$ or endurance $(n=240)$ athletes. Descriptive characteristics are presented in Table 5.1. Detailed information on the specific sport disciplines within each category, and corresponding descriptive characteristics, are presented in Table 5.2.

\section{Dietary Protein Intake}

Daily protein intake data for the individual sport categories are presented in Table 5.1. Average energy

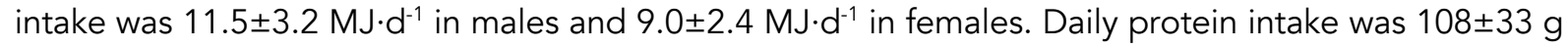
$\left(1.5 \pm 0.4 \mathrm{~g} \mathrm{~kg}^{-1}\right)$ in males and $90 \pm 24 \mathrm{~g}\left(1.4 \pm 0.4 \mathrm{~g} \mathrm{~kg}^{-1}\right)$ in females, representing $16 \pm 3$ and $17 \pm 3 \%$ of energy intake (EN\%), respectively. Protein intake was well above the recommended $1.2 \mathrm{~g} \cdot \mathrm{kg}^{-1} \cdot \mathrm{d}^{-1}$ in $73 \%$ of athletes, and ranged from 0.5 to 2.7 and 0.4 to $3.6 \mathrm{~g} \cdot \mathrm{kg}^{-1} \cdot \mathrm{d}^{-1}$ in the male and female athletes, respectively. Dietary protein intake strongly correlated with daily energy intake in strength $(r=0,71$; $p<0.001)$, team sports $(r=0.77 ; p<0.001)$, and endurance $(r=0.79 ; p<0.001)$ athletes (Figure 5.1).

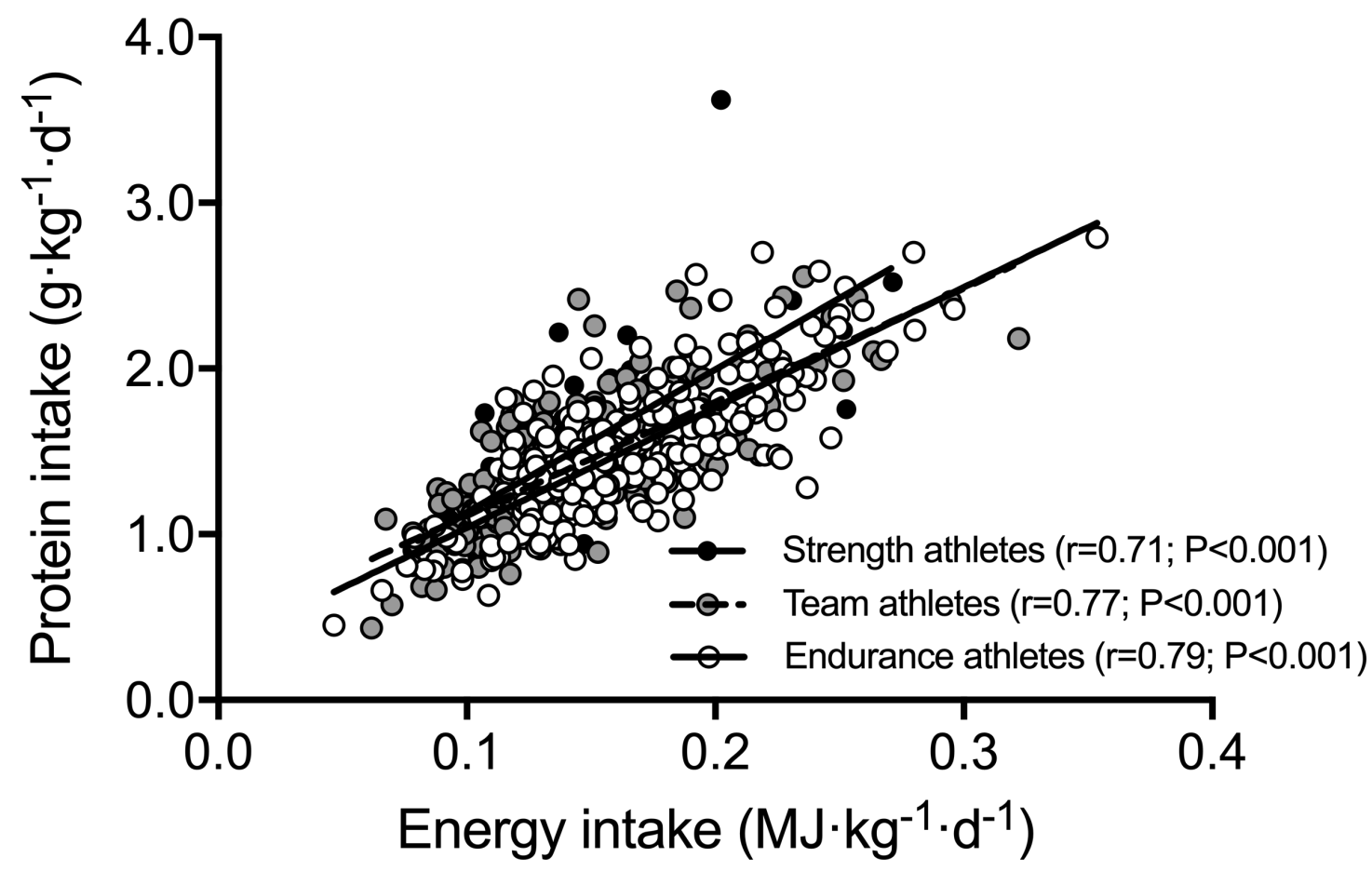

Figure 5.1. Relationship between dietary energy intake and total protein intake in strength, team-sport, and endurance athletes.

\section{Dietary Protein Sources}

Plant and animal-based protein sources contributed 43 and $57 \%$ of total protein intake, respectively (Table 5.1). The contribution of various plant and animal-based protein food sources is depicted in Figure 5.2. Meat, meat products and poultry were the most dominant protein-containing food source, representing $32 \%$ of total protein intake. Bread was the most prevalent plant-based protein source, contributing $19 \%$ of total protein intake (Figure 5.2). Plant-based protein sources contributed $50 \%$ of protein intake at breakfast $(10 \pm 5 \mathrm{~g})$ and lunch $(12 \pm 7 \mathrm{~g})$ and $29 \%$ at dinner $(11 \pm 5 \mathrm{~g})$. Thus, animal-based 
protein sources contributed $50 \%$ of protein intake at breakfast $(9 \pm 5 \mathrm{~g})$ and lunch $(13 \pm 10 \mathrm{~g})$, and $71 \%$ at dinner (26 $\pm 14 \mathrm{~g})$ (Figure 5.3).

\section{All Athletes $(n=553)$}

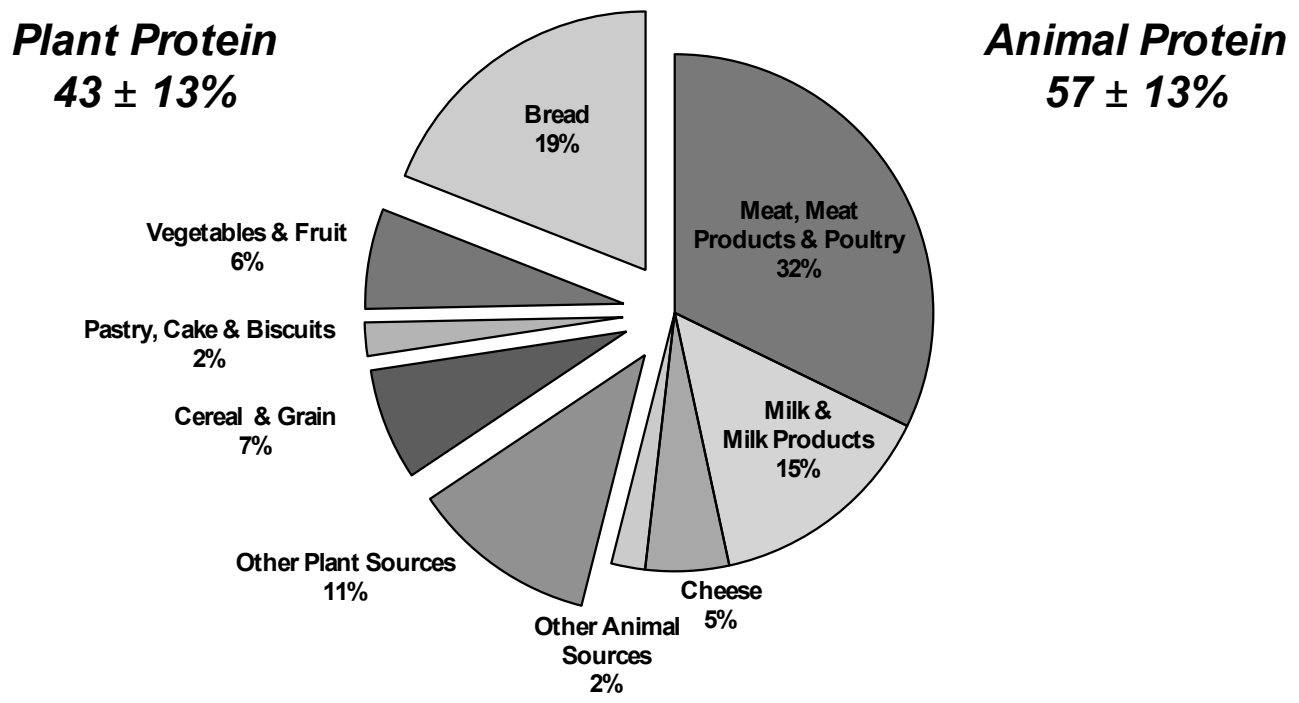

Figure 5.2. Contribution of plant and animal food sources to total daily protein intake in athletes.

\section{Dietary Protein Intake Distribution}

Protein intake at breakfast $(19 \pm 8 \mathrm{~g})$, lunch $(25 \pm 13 \mathrm{~g})$ and dinner $(38 \pm 15 \mathrm{~g})$ contributed $81 \%$ of total protein intake (Figure 5.3). Protein intake at the main meals was below the recommended $20 \mathrm{~g}$ per serving in $58 \%$ of the athletes at breakfast, $36 \%$ at lunch, and $8 \%$ at dinner.

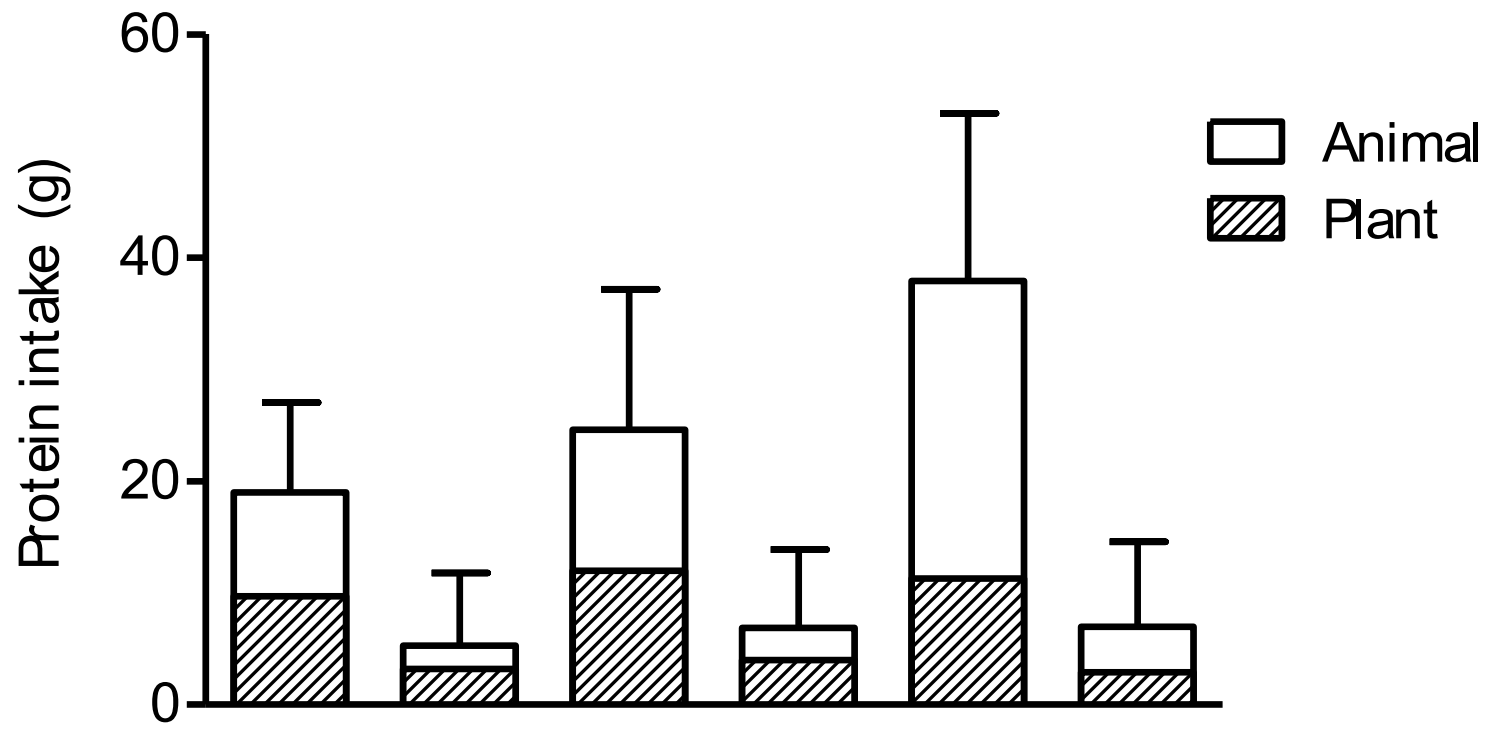

Figure 5.3. Distribution and sources of dietary protein intake throughout the day among athletes. 


\section{Protein Supplementation}

Protein supplements were used among $16 \%$ of the strength athletes, $7 \%$ of the team sports athletes and $11 \%$ of the endurance type athletes (Figure 5.4 ). Among all athlete groups, average dietary protein intake was $98 \pm 29 \mathrm{~g}\left(1.5 \pm 0.4 \mathrm{~g} \cdot \mathrm{kg}^{-1} \cdot \mathrm{d}^{-1}\right)$ in non-supplement users and $130 \pm 42 \mathrm{~g}\left(1.7 \pm 0.5 \mathrm{~g} \mathrm{~kg}^{-1} \cdot \mathrm{d}^{-1}\right)$ in supplement users. Supplemental protein provided $22 \pm 11 \mathrm{~g}\left(0.3 \pm 0.2 \mathrm{~g} \cdot \mathrm{kg}^{-1} \cdot \mathrm{d}^{-1}\right)$, resulting in a total protein intake of $152 \pm 44 \mathrm{~g}\left(2.0 \pm 0.5 \mathrm{~g} \cdot \mathrm{kg}^{-1} \cdot \mathrm{d}^{-1}\right)$ among supplement-users (Figure 5.4).

\section{Strength Athletes $(n=71)$}

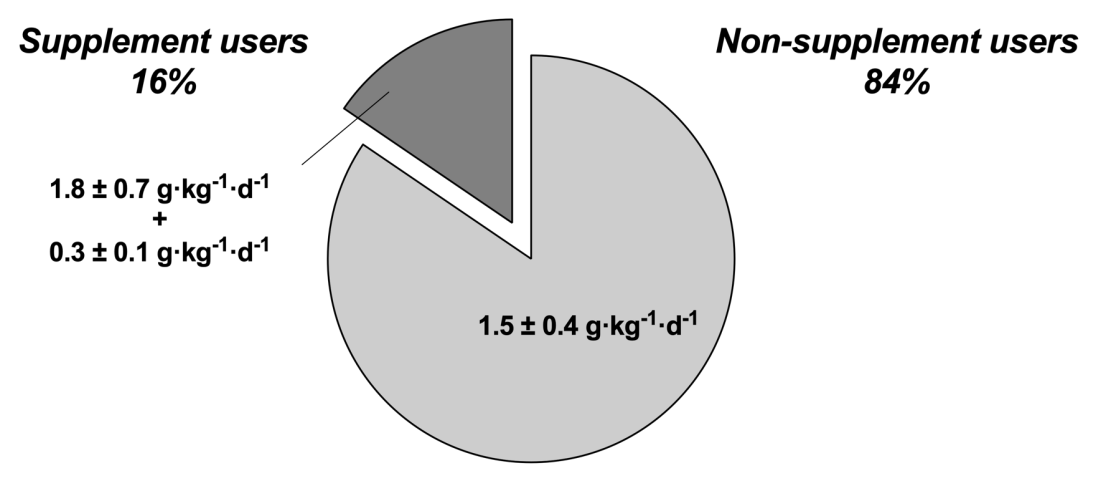

Team Sports Athletes $(n=242)$

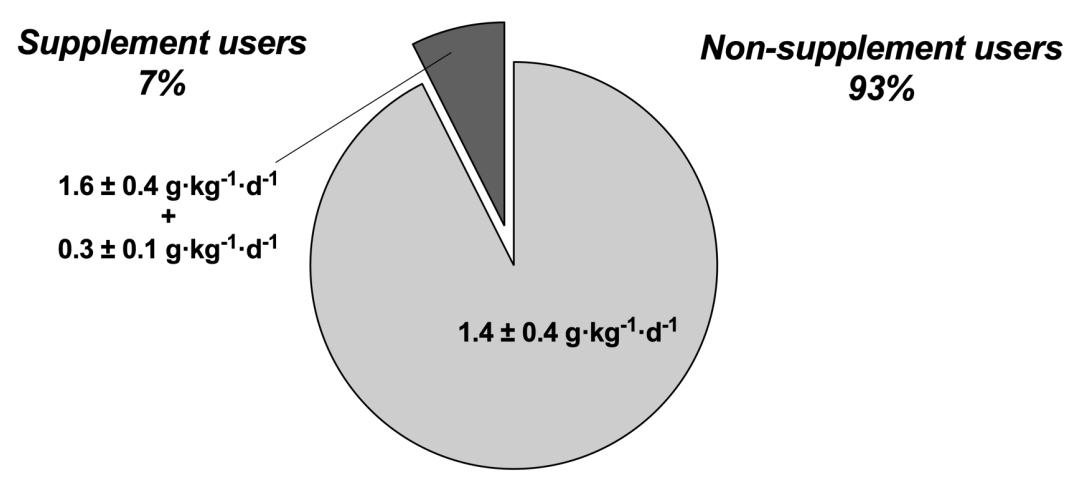

Endurance Athletes $(n=240)$

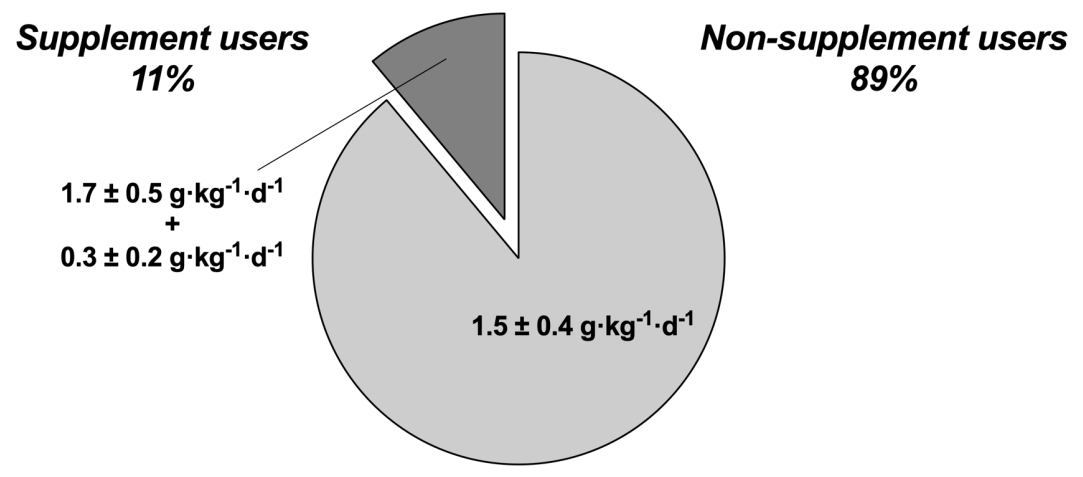

Figure 5.4. Prevalence of protein supplementation among strength (A), team-sport (B) and endurance (C) type athletes. Contribution of dietary, or dietary + supplemental protein $\left(\mathrm{g} \cdot \mathrm{kg}^{-1} \cdot \mathrm{d}^{-1}\right)$, is depicted for all athletes groups. 


\section{DISCUSSION}

The present study shows that daily protein intake is closely related to total energy intake in well-trained athletes. Athletes typically consumed well above the recommended $1.2 \mathrm{~g}$ of protein $\cdot \mathrm{kg}^{-1} \cdot \mathrm{d}^{-1}$ from their habitual diet, which was largely attributed to the relatively high daily energy intake. While the majority of protein consumed originated from animal-based food sources, plant-based proteins contributed more than $40 \%$ of daily dietary protein intake. More than $80 \%$ of daily protein consumption was distributed over the three main meals, with the largest intake at dinner $(\sim 38 \mathrm{~g})$. These findings are the first to characterize the quantity and distribution of specific protein-containing food sources in a large cohort of well-trained athletes, providing valuable information for optimizing patterns of protein intake in athletes.

Consumption of adequate dietary protein is a fundamental component of proper recovery from the physiological stress of prolonged exercise training. While it was originally proposed that the recommended daily allowance of $0.8 \mathrm{~g} \cdot \mathrm{kg}^{-1} \cdot \mathrm{d}^{-1}$ was sufficient for everyone, including athletes [5], it is now believed that athletes involved in strenuous exercise require a greater daily protein intake $[6,7]$. As such, protein intake recommendations for athletes have focused on the quantity of daily protein, with guidelines increasing from $1.2-1.6$ [6], $1.2-1.7$ [8] and most recently, $1.3-1.8 \mathrm{~g} \mathrm{~kg}^{-1} \cdot \mathrm{d}^{-1}$ [9]. It is well established that the protein content of a healthy diet typically ranges between 15-25 EN\% [10], implying that dietary protein intake is strongly determined by total energy intake. Indeed, in the present study we observed a strong positive correlation between habitual protein consumption and total energy intake (Figure 5.1). Given the relatively high daily energy intake in both the male and female athletes, habitual protein intakes averaged $\sim 1.5 \mathrm{~g} \mathrm{~kg}^{-1} \cdot \mathrm{d}^{-1}$, representing $17 \%$ of daily energy intake. Consequently, dietary protein consumption was well above the suggested lower limit of $1.2 \mathrm{~g} \cdot \mathrm{kg}^{-1} \cdot \mathrm{d}^{-1}$ in all athletes, regardless of supplemental protein use. These findings show that dietary protein intake in athletes is largely determined by total energy intake, resulting in a level of daily protein intake well within the recommended guidelines. Thus, it may be more strategic for protein recommendations to move beyond total intake, and focus more on other factors known to modulate the efficacy of dietary protein to support skeletal muscle repair and remodeling.

The specific food sources contributing to dietary protein intake may be an important consideration for optimizing protein consumption in athletes. Daily protein intake is derived from a number of proteincontaining food sources, however information on the specific food sources that contribute to total protein intake in athletes is scarce. Plant-based proteins are considered to have lower anabolic properties than animal-based proteins [13, 14], however plant-based food sources contribute substantially to the protein intake of a traditional diet [12]. Indeed, our findings revealed that more than $40 \%$ of daily dietary protein intake originates from plant-based sources in well-trained athletes, with bread as the dominant food source (Figure 5.2). The contribution of plant-based protein sources to protein intake was greater at breakfast and lunch (50\%), and less prevalent at dinner when $>70 \%$ of protein originated from animal-based food sources. These data are the first to show that plant-based proteins represent a substantial proportion of total daily protein intake in well-trained athletes.

Various strategies have been proposed to augment the anabolic properties of plant-based proteins, including fortification with essential amino acids or the blending of various plant protein sources, with or without animal protein, to improve amino acid composition [12]. In the present study, all meals contained a blend of various plant- and animal-based protein sources, which may limit the proposed 
relative deficiency of essential amino acids in various plant-based proteins. Given the substantial contribution of plant-based food sources to total protein intake, it seems imperative that guidelines for optimizing protein intake in athletes incorporate strategies to augment the anabolic properties of mixed meals.

The distribution of dietary protein intake throughout the day also represents an important consideration for optimizing protein intake in athletes. In the present study, more than $80 \%$ of protein intake was distributed over breakfast ( 19 g), lunch ( 25 g) and dinner ( 38 g), revealing a skewed pattern of protein intake towards the evening meal (Figure 5.3). It has been demonstrated that post-prandial muscle protein synthesis rates are maximized following ingestion of a $20-25 \mathrm{~g}$ bolus of high quality protein [15-17]. For this reason, consuming a balanced distribution of protein throughout the day, consisting of 4-5 evenly spaced feedings of $20 \mathrm{~g}$ high quality protein, has been suggested to be optimal for maximizing post-prandial muscle protein synthesis rates $[9,18,19]$. Though total protein intake of our athletes $\left(\sim 1.5 \mathrm{~g} \mathrm{~kg}^{-1} \cdot \mathrm{d}^{-1}\right)$ were well within the recommended guidelines, meals containing $20 \mathrm{~g}$ protein or more were only consumed three times per day. Closer evaluation revealed that protein intake was below $20 \mathrm{~g}$ in $58 \%$ of athletes at breakfast and $36 \%$ at lunch, despite group averages at or above the $20 \mathrm{~g}$ protein minimum. Our findings highlight that many athletes may have suboptimal practices when it comes to protein intake distribution throughout the day.

A potentially important and perhaps overlooked opportunity to consume a high-protein meal is before going to bed. We have previously shown that protein ingested prior to [23] or during [24] sleep is properly digested and absorbed, increasing amino acid availability and augmenting overnight muscle protein synthesis rates. When evaluated over the long-term, ingestion of a protein supplement prior to sleep was shown to augment gains in muscle mass and strength gains during a 12-week resistancetype exercise training program in young men [25]. Consistent with previous reports [20], athletes in the present study only consumed $\sim 7 \mathrm{~g}$ of protein as part of their evening snack. Promoting a more balanced distribution of dietary protein intake throughout the day, including a protein-rich pre-sleep snack, may represent an effective dietary strategy to improve post-exercise muscle recovery and optimize skeletal muscle reconditioning in athletes.

To conclude, daily protein intake is strongly determined by total energy intake in well-trained athletes. Given the higher energy intake among active athletes, protein consumption from dietary sources exceeds well beyond the recommended $1.2 \mathrm{~g} \mathrm{~kg}^{-1} \cdot \mathrm{d}^{-1}$. Protein supplementation is not required for athletes to meet the current recommendations for daily protein intake. Though most protein consumed is of animal origin, plant-based food sources contribute more than $40 \%$ of daily protein consumption. The three main meals provide the majority $(80 \%)$ of protein intake, with the highest quantities consumed at dinner ( $38 \mathrm{~g}$ ). Though athletes generally consume ample protein, distribution of daily protein intake remains far from what is believed to be optimal to support skeletal muscle reconditioning. Recommendations for protein intake in athletes should move beyond total protein intake and focus more on optimizing protein quality and protein intake distribution to support the skeletal muscle adaptive response to prolonged exercise training.

\section{ACKNOWLEDGEMENTS}

This study was designed by JBG, JT and LJCVL; data was collected by FCW, NYJB, JdV and JJGCvdB; 
data analysis was performed by JBG, JT, JJV, KLJ and CK; data interpretation was performed by JBG, $J T, M J G$ and LJCVL; the manuscript was drafted by JBG with input from JT, LJCVL, MJG, FCW, NYJB, $J J V, K L J, C K, J d V$ and JJGCvdB; all authors approved the final version of the manuscript. This manuscript was made possible because of The Naomi Cermak Memorial Graduate Travel Scholarship awarded to JBG.

\section{FUNDING SOURCES}

Partly supported by a grant from Friesland Campina, the Netherlands and a regional government grant as part of the Eat2Move project of the province of Gelderland, the Netherlands, proposal PS2014-49.

\section{CONFLICTS OF INTEREST}

The authors declare they have no conflicts of interest. 


\section{REFERENCES}

1. Morton RW, McGlory C, Phillips SM. Nutritional interventions to augment resistance traininginduced skeletal muscle hypertrophy. Front Physiol. 2015;6:245.

2. Cermak NM, Res PT, de Groot LC, Saris WH, van Loon LJ. Protein supplementation augments the adaptive response of skeletal muscle to resistance-type exercise training: a meta-analysis. The American journal of clinical nutrition. 2012 Dec;96(6):1454-64.

3. Koopman R, Pannemans DL, Jeukendrup AE, Gijsen AP, Senden JM, Halliday D, et al. Combined ingestion of protein and carbohydrate improves protein balance during ultraendurance exercise. American journal of physiology Endocrinology and metabolism. 2004 Oct;287(4):E712-20.

4. Moore DR, Camera DM, Areta JL, Hawley JA. Beyond muscle hypertrophy: why dietary protein is important for endurance athletes. Applied Physiology Nutrition and Metabolism. 2014 Sep;39(9):987-97.

5. Medicine lo. Dietary Reference Intakes for Energy, Carbohydrate, Fiber, Fat, Fatty Acids, Cholesterol, Protein, and Amino Acids. Washington, DC: The National Academies Press; 2005.

6. Phillips SM, Moore DR, Tang JE. A critical examination of dietary protein requirements, benefits, and excesses in athletes. International journal of sport nutrition and exercise metabolism. 2007 Aug;17 Suppl:S58-76.

7. Tarnopolsky M. Protein requirements for endurance athletes. Nutrition. 2004 Jul-Aug;20(78):662-8.

8. Rodriguez NR, DiMarco NM, Langley S. Position of the American Dietetic Association, Dietitians of Canada, and the American College of Sports Medicine: Nutrition and athletic performance. Journal of the American Dietetic Association. 2009 Mar;109(3):509-27.

9. Phillips SM, Van Loon LJC. Dietary protein for athletes: From requirements to optimum adaptation. Journal of Sports Sciences. 2011;29:S29-S38.

10. Fulgoni VL, 3rd. Current protein intake in America: analysis of the National Health and Nutrition Examination Survey, 2003-2004. The American journal of clinical nutrition. 2008 May;87(5):1554s-7s.

11. Saris WH, van Erp-Baart MA, Brouns F, Westerterp KR, ten Hoor F. Study on food intake and energy expenditure during extreme sustained exercise: the Tour de France. International journal of sports medicine. 1989 May;10 Suppl 1:S26-31.

12. van Vliet S, Burd NA, van Loon LJ. The Skeletal Muscle Anabolic Response to Plant- versus Animal-Based Protein Consumption. The Journal of nutrition. 2015 Sep;145(9):1981-91.

13. Tang JE, Moore DR, Kujbida GW, Tarnopolsky MA, Phillips SM. Ingestion of whey hydrolysate, casein, or soy protein isolate: effects on mixed muscle protein synthesis at rest and following resistance exercise in young men. Journal of applied physiology (Bethesda, Md : 1985). 2009 Sep;107(3):987-92.

14. Hartman JW, Tang JE, Wilkinson SB, Tarnopolsky MA, Lawrence RL, Fullerton AV, et al. Consumption of fat-free fluid milk after resistance exercise promotes greater lean mass accretion than does consumption of soy or carbohydrate in young, novice, male weightlifters. American Journal of Clinical Nutrition. 2007 Aug;86(2):373-81. 
15. Witard OC, Jackman SR, Breen L, Smith K, Selby A, Tipton KD. Myofibrillar muscle protein synthesis rates subsequent to a meal in response to increasing doses of whey protein at rest and after resistance exercise. American Journal of Clinical Nutrition. 2014 Jan;99(1):86-95.

16. Moore DR, Robinson MJ, Fry JL, Tang JE, Glover El, Wilkinson SB, et al. Ingested protein dose response of muscle and albumin protein synthesis after resistance exercise in young men. The American journal of clinical nutrition. 2009 Jan;89(1):161-8.

17. Cuthbertson D, Smith K, Babraj J, Leese G, Waddell T, Atherton P, et al. Anabolic signaling deficits underlie amino acid resistance of wasting, aging muscle. FASEB journal : official publication of the Federation of American Societies for Experimental Biology. 2005 Mar;19(3):422-4.

18. Mamerow MM, Mettler JA, English KL, Casperson SL, Arentson-Lantz E, Sheffield-Moore M, et al. Dietary protein distribution positively influences $24-\mathrm{h}$ muscle protein synthesis in healthy adults. The Journal of nutrition. 2014 Jun;144(6):876-80.

19. Areta JL, Burke LM, Ross ML, Camera DM, West DW, Broad EM, et al. Timing and distribution of protein ingestion during prolonged recovery from resistance exercise alters myofibrillar protein synthesis. The Journal of physiology. 2013 May 01;591(9):2319-31.

20. Erdman KA, Tunnicliffe J, Lun VM, Reimer RA. Eating patterns and composition of meals and snacks in elite Canadian athletes. International journal of sport nutrition and exercise metabolism. 2013 Jun;23(3):210-9.

21. Conway JM, Ingwersen LA, Vinyard BT, Moshfegh AJ. Effectiveness of the US Department of Agriculture 5-step multiple-pass method in assessing food intake in obese and nonobese women. The American journal of clinical nutrition. 2003 May;77(5):1171-8.

22. Wardenaar FC, Steennis J, Ceelen IJ, Mensink M, Witkamp R, de Vries JH. Validation of webbased, multiple 24-h recalls combined with nutritional supplement intake questionnaires against nitrogen excretions to determine protein intake in Dutch elite athletes. The British journal of nutrition. 2015 Dec 28;114(12):2083-92.

23. Res PT, Groen B, Pennings B, Beelen M, Wallis GA, Gijsen AP, et al. Protein Ingestion before Sleep Improves Postexercise Overnight Recovery. Medicine and Science in Sports and Exercise. 2012 Aug;44(8):1560-9.

24. Groen BB, Res PT, Pennings B, Hertle E, Senden JM, Saris WH, et al. Intragastric protein administration stimulates overnight muscle protein synthesis in elderly men. American journal of physiology Endocrinology and metabolism. 2012 Jan 01;302(1):E52-60.

25. Snijders T, Res PT, Smeets JS, van Vliet S, van Kranenburg J, Maase K, et al. Protein Ingestion before Sleep Increases Muscle Mass and Strength Gains during Prolonged Resistance-Type Exercise Training in Healthy Young Men. The Journal of nutrition. 2015 Jun;145(6):1178-84. 


\section{Chapter 6}

Resistance exercise augments postprandial overnight muscle protein synthesis rates

Jorn Trommelen; Andrew M. Holwerda; Imre W.K. Kouw; Henning Langer; Shona L. Halson; Ian Rollo; Lex B. Verdijk; Luc J.C. van Loon 


\section{ABSTRACT}

Background: We have previously shown that protein ingestion prior to sleep increases overnight muscle protein synthesis rates. Whether prior exercise further augments the muscle protein synthetic response to pre-sleep protein ingestion remains to be established.

Purpose: To assess whether resistance-type exercise performed in the evening increases the overnight muscle protein synthetic response to pre-sleep protein ingestion.

Methods: Twenty four healthy young men were randomly assigned to ingest $30 \mathrm{~g}$ intrinsically L- $\left[1-{ }^{13} \mathrm{C}\right]-$ phenylalanine and L- $\left[1-{ }^{13} \mathrm{C}\right]$-leucine labeled casein protein before going to sleep with (PRO+EX: $n=12$ ) or without (PRO: $n=12$ ) prior resistance-type exercise performed in the evening. Continuous intravenous L-[ring- $\left.{ }^{2} \mathrm{H}_{5}\right]$-phenylalanine, L-[1-13 $\left.\mathrm{C}\right]$-leucine and $\mathrm{L}$-[ring- $\left.{ }^{2} \mathrm{H}_{2}\right]$-tyrosine infusions were applied. Blood and muscle tissue samples were collected to assess whole-body protein balance, myofibrillar protein synthesis rates and overnight incorporation of dietary protein-derived amino acids into de novo myofibrillar protein.

Results: $A$ total of $57 \pm 1 \%$ of the ingested protein-derived phenylalanine appeared in the circulation during overnight sleep. Overnight myofibrillar protein synthesis rates were $37 \%(0.055 \pm 0.002$ vs $0.040 \pm 0.003 \% \cdot h^{-1}, P<0.001$; based upon L-[ring- $\left.{ }^{2} \mathrm{H}_{5}\right]$-phenylalanine) and $31 \%(0.073 \pm 0.004$ vs $0.055 \pm 0.006 \% \cdot h^{-1}, P=0.024$; based upon $L-\left[1-{ }^{13} \mathrm{C}\right]$-leucine) higher in PRO+EX compared to PRO. Substantially more of the dietary protein-derived amino acids were incorporated into de novo myofibrillar protein during overnight sleep in $P R O+E X$ compared to $P R O(0.026 \pm 0.003$ vs $0.015 \pm 0.003$ MPE, $P=0.012$ ).

Conclusion: Resistance-type exercise performed in the evening augments the overnight muscle protein synthetic response to pre-sleep protein ingestion and allows more of the ingested protein-derived amino acids to be used for de novo myofibrillar protein synthesis during overnight sleep. 


\section{INTRODUCTION}

A single session of resistance-type exercise stimulates both muscle protein synthesis and breakdown rates [1-3]. Protein ingestion after exercise stimulates muscle protein synthesis and inhibits muscle protein breakdown, resulting in net muscle protein accretion during the acute stages of post-exercise recovery [4-6]. Therefore, post-exercise protein ingestion is widely applied as a strategy to increase post-exercise muscle protein synthesis rates and, as such, to stimulate post-exercise recovery and facilitate skeletal muscle reconditioning. Various factors have been identified that can modulate the post-exercise muscle protein synthetic response including the amount $[7,8]$, type $[9,10]$ and timing $[11,12]$ of protein ingestion.

Previously, we have demonstrated that protein ingested prior to sleep is properly digested and absorbed, thereby increasing overnight amino acid availability, and stimulating muscle protein synthesis during overnight sleep [13,14]. Based upon these findings we suggested that protein ingestion prior to sleep may represent a practical and effective interventional strategy to support muscle mass maintenance and/or stimulate muscle hypertrophy. In this regard, pre-sleep protein supplementation has recently been applied in a prolonged resistance-type exercise training regimen, allowing greater gains in muscle mass and strength [15]. In this study, subjects ingested either $\sim 30 \mathrm{~g}$ of additional protein or a noncaloric placebo prior to sleep during a 3 month resistance-type exercise training program, with supplements ingested on both training days ( 3 times/wk) and non-training days. Though pre-sleep protein supplementation was effective in further increasing muscle mass and strength gains when compared to a placebo, the acute effects of resistance-type exercise on the muscle protein synthetic response to protein ingestion prior to sleep remains to be determined.

The aim of the present study was to assess whether resistance-type exercise performed in the evening increases the overnight muscle protein synthetic response to pre-sleep protein ingestion. We hypothesized that resistance-type exercise performed in the evening augments the muscle protein synthetic response to pre-sleep protein ingestion, allowing more of the ingested protein to be used for de novo myofibrillar protein accretion during overnight sleep. Therefore, we studied 24 recreationally active young males who ingested $30 \mathrm{~g}$ intrinsically $\mathrm{L}-\left[1-{ }^{13} \mathrm{C}\right]$-phenylalanine and $\mathrm{L}-\left[1-{ }^{13} \mathrm{C}\right]-$ leucine labeled casein protein before going to sleep with (PRO+EX) or without prior exercise (PRO) being performed in the evening. By combining the use of specifically produced intrinsically $L-\left[1-{ }^{13} \mathrm{C}\right]-$ phenylalanine and $\mathrm{L}-\left[1-{ }^{13} \mathrm{C}\right]$-leucine labeled casein with primed continuous infusion of $\mathrm{L}-\left[\mathrm{ring}_{-}{ }^{2} \mathrm{H}_{5}\right]-$ phenylalanine, $\mathrm{L}-\left[1-{ }^{13} \mathrm{C}\right]$-leucine and $\mathrm{L}-\left[\mathrm{ring}_{-}{ }^{2} \mathrm{H}_{2}\right]$-tyrosine, we were able to assess protein digestion and amino acid absorption kinetics, whole-body protein metabolism, muscle protein synthesis rates as well as the metabolic fate of the dietary protein-derived amino acids towards de novo myofibrillar protein accretion during overnight sleep. 


\section{METHODS}

\section{Subjects}

A total of 24 healthy, recreationally active (participating in exercise other than structured resistancetype exercise, for 1-3 d.wk-1 for $\geq 12$ months), young men were selected to participate in this study. Subjects' characteristics are presented in Table 6.1. Subjects were randomly assigned to ingest $30 \mathrm{~g}$ intrinsically L-[1- $\left.-{ }^{13} \mathrm{C}\right]$-phenylalanine and $\mathrm{L}-\left[1-{ }^{13} \mathrm{C}\right]$-leucine labeled casein protein before going to sleep with (PRO+EX, $n=12)$ or without a bout of resistance-type exercise $(P R O, n=12)$ being performed in the evening (19:45 - 20:45 PM). All subjects were fully informed of the nature and possible risks of the experimental procedures before their written informed consent was obtained. This study is part of a greater project investigating the impact of pre-sleep protein feeding on overnight muscle protein synthesis. The project was registered at Netherlands Trial Registry as NTR3885, was approved by the Medical Ethical Committee of the Maastricht University Medical Centre, The Netherlands, and conformed to standards for the use of human subjects in research as outlined in the most recent version of the Helsinki Declaration.

Table 6.1. Subjects' characteristics

\begin{tabular}{|c|c|c|c|c|c|}
\hline \multirow[b]{2}{*}{ Age (y) } & \multicolumn{2}{|c|}{$\begin{array}{l}\text { PRO } \\
(n=12)\end{array}$} & \multicolumn{3}{|c|}{$\begin{array}{c}\text { PRO+EX } \\
(n=12)\end{array}$} \\
\hline & 24 & \pm 1 & 23 & \pm & 1 \\
\hline Weight (kg) & 77.6 & \pm 1.2 & 73.0 & \pm & $1.7^{*}$ \\
\hline BMI $\left(\mathrm{kg} \cdot \mathrm{m}^{-2}\right)$ & 21.9 & $\pm \quad 0.4$ & 22.1 & \pm & 0.5 \\
\hline Fat (\%) & 13 & \pm 1 & 14 & \pm & 1 \\
\hline LBM (kg) & 61.9 & \pm 1.2 & 59.5 & \pm & 1.6 \\
\hline Leg volume (L) & 9.2 & \pm 0.2 & 9.0 & \pm & 0.3 \\
\hline
\end{tabular}

Values represent means \pm SEM. PRO: pre-sleep protein ingestion without prior exercise, PRO+EX: pre-sleep protein ingestion with prior exercise. BMI: body mass index. * Significantly different from PRO $(P=0.036)$. Data were analyzed with a Students' ttest.

\section{Pretesting}

Bodyweight and body composition (fat and fat-free mass) were determined by DEXA (Dual-energy Xray absorptiometry, DEXA; Discovery A; Hologic, Bedford, USA). Leg volume was determined by anthropometry measurements as described by Jones and Pearson [16]. The subjects were then familiarized with the resistance-type exercise protocol and the exercise equipment. All exercises during pretesting and experimental trials were supervised by trained personnel. Subjects started by performing a 10-min cycling warm-up at $150 \mathrm{~W}$ before completing an estimation of their 1RM on the leg press and leg extension exercises using the multiple repetitions testing procedure [17]. For each exercise, subjects performed 10 submaximal repetitions to become familiarized with the equipment and to have lifting technique critiqued and properly adjusted. Sets were then performed at progressively increasing loads until failure to perform a valid estimation within 3-6 repetitions of the set. A repetition was valid if the subject was able to complete the entire lift in a controlled manner without assistance. A 2 min resting period between subsequent attempts was allowed. The pretesting and experimental trials were separated by at least $7 \mathrm{~d}$. 


\section{Diet and physical activity}

All subjects were instructed to refrain from exhaustive physical labor and exercise and to keep their diet as constant as possible $2 \mathrm{~d}$ before the experimental day. Food intake and physical activity questionnaires were collected for $2 \mathrm{~d}$ prior to the experiment. All subjects received a standardized diet throughout the experimental day $\left(0.16 \mathrm{MJ} \mathrm{kg}^{-1}\right.$, providing 62 energy percentage (En\%) carbohydrate, $13 \mathrm{En} \%$ protein, and $22 \mathrm{En} \%$ fat). The energy content of the standardized diet was based upon individual energy requirements based upon the Harris-Benedict equation and adjusted using a physical activity factor of 1.6 to ensure ample energy intake. During the experimental day, participants ingested $1.2 \pm 0.01 \mathrm{~g}$ protein $\cdot \mathrm{kg}$ bodyweight ${ }^{-1}$ via the standardized diet with an additional $20 \mathrm{~g}\left(0.27 \pm 0.01 \mathrm{~g} \cdot \mathrm{kg}^{-}\right.$ 1) of protein provided at $20: 45 \mathrm{~h}$ and an additional $30 \mathrm{~g}$ of protein $\left(0.40 \pm 0.01 \mathrm{~g} \cdot \mathrm{kg}^{-1}\right)$ provided prior to sleep (23:30 h).

\section{Experimental Protocol}

An outline of the study protocol is provided in Figure 6.1. At 17:30 h, participants reported to the lab and had Teflon catheters inserted into the antecubital veins of each arm. At 18:30 h ( $\mathrm{t}=-300 \mathrm{~min}$ ), all the subjects consumed a standardized dinner (Sligro, Maastricht, the Netherlands) under supervision (0.04 MJ $\mathrm{kg}^{-1}$, providing $55 \mathrm{En} \%$ carbohydrate, $21 \mathrm{En} \%$ protein, and $20 \mathrm{En} \%$ fat), after which no more solid food was consumed. Subjects in the PRO+EX group subsequently performed a resistance-type exercise bout between 19:45 and 20:45 h. Subjects in the PRO group rested in a sitting position during this period. Immediately after the exercise or rest session, both the PRO and PRO+EX group received drinks providing $20 \mathrm{~g}$ protein and $45 \mathrm{~g}$ carbohydrate (Gatorade G-series 03 Recover protein recovery shake, the Gatorade Company, Chicago, USA), which were ingested within $2 \mathrm{~min}$. The purpose of this recovery drink was to optimize muscle protein synthesis rates in the hours prior to sleep [18]. Following protein ingestion, a background blood sample was taken prior to the initiation of the tracer infusion protocol, which was started at 21:00 h ( $t=-150 \mathrm{~min})$. The plasma and intracellular phenylalanine and leucine pools were primed with a single intravenous dose (priming dose) of $\mathrm{L}-\left[\mathrm{ring}_{-}{ }^{2} \mathrm{H}_{5}\right]$-phenylalanine $\left(2.0 \mu \mathrm{mol} \cdot \mathrm{kg}^{-1}\right), \mathrm{L}-\left[\right.$ ring $\left.{ }^{2}{ }^{2} \mathrm{H}_{2}\right]$-tyrosine $\left(0.615 \mu \mathrm{mol} \cdot \mathrm{kg}^{-1}\right)$, and $\mathrm{L}-\left[1{ }^{13} \mathrm{C}\right]$-leucine $\left(4.0 \mu \mathrm{mol} \cdot \mathrm{kg}^{-1}\right)$. Once primed, the continuous stable isotope infusion was initiated (infusion rate: $0.05 \mu \mathrm{mol} \cdot \mathrm{kg}^{-1} \cdot \mathrm{min}^{-1} \mathrm{~L}$-[ring$\left.{ }^{2} \mathrm{H}_{5}\right]$-phenylalanine, $0.015 \mu \mathrm{mol} \cdot \mathrm{kg}^{-1} \cdot \mathrm{min}^{-1} \mathrm{~L}$-[ring $\left.{ }^{2} \mathrm{H}_{2}\right]$-tyrosine, $0.1 \mu \mathrm{mol} \cdot \mathrm{kg}^{-1} \cdot \mathrm{min}^{-1} \mathrm{~L}-\left[1{ }^{13} \mathrm{C}\right]$-leucine): Cambridge Isotopes Laboratories, Andover, MA). Participants rested in a supine position for $2.5 \mathrm{~h}$ until 23:30 h ( $\mathrm{t}=0 \mathrm{~min}$ ), after which the first muscle biopsy was taken. Subsequently, subjects ingested a 450 $\mathrm{mL}$ beverage containing $30 \mathrm{~g}$ intrinsically $\mathrm{L}-\left[1-{ }^{13} \mathrm{C}\right]$-phenylalanine and $\mathrm{L}-\left[1-{ }^{13} \mathrm{C}\right]$-leucine labeled casein with an added $1.5 \mathrm{~mL}$ of vanilla extract (Dr. Oetker, Amersfoort, the Netherlands) within $5 \mathrm{~min}$. Subjects went to sleep at 00:00 h. During the night, blood samples $(10 \mathrm{~mL})$ were taken without waking up the subjects at $t=30,60,90,150,210,330$, and 450 min relative to the intake of the protein drink. $A$ second muscle biopsy was obtained from the contralateral leg $7.5 \mathrm{~h}$ later at 07:00 h ( $\mathrm{t}=450 \mathrm{~min}$ ).

Blood samples were collected in tubes containing EDTA and centrifuged at $1000 \mathrm{~g}$ for $10 \mathrm{~min}$ at $4^{\circ} \mathrm{C}$. Aliquots of plasma were frozen in liquid nitrogen and stored at $-80^{\circ} \mathrm{C}$. Muscle biopsies were obtained from the middle region of the $M$. vastus lateralis, $15 \mathrm{~cm}$ above the patella and approximately $4 \mathrm{~cm}$ below entry through the fascia, using the percutaneous needle biopsy technique [19]. Muscle samples were dissected carefully and freed from any visible non-muscle material. The muscle samples were immediately frozen in liquid nitrogen and stored at $-80^{\circ} \mathrm{C}$ until further analysis. 


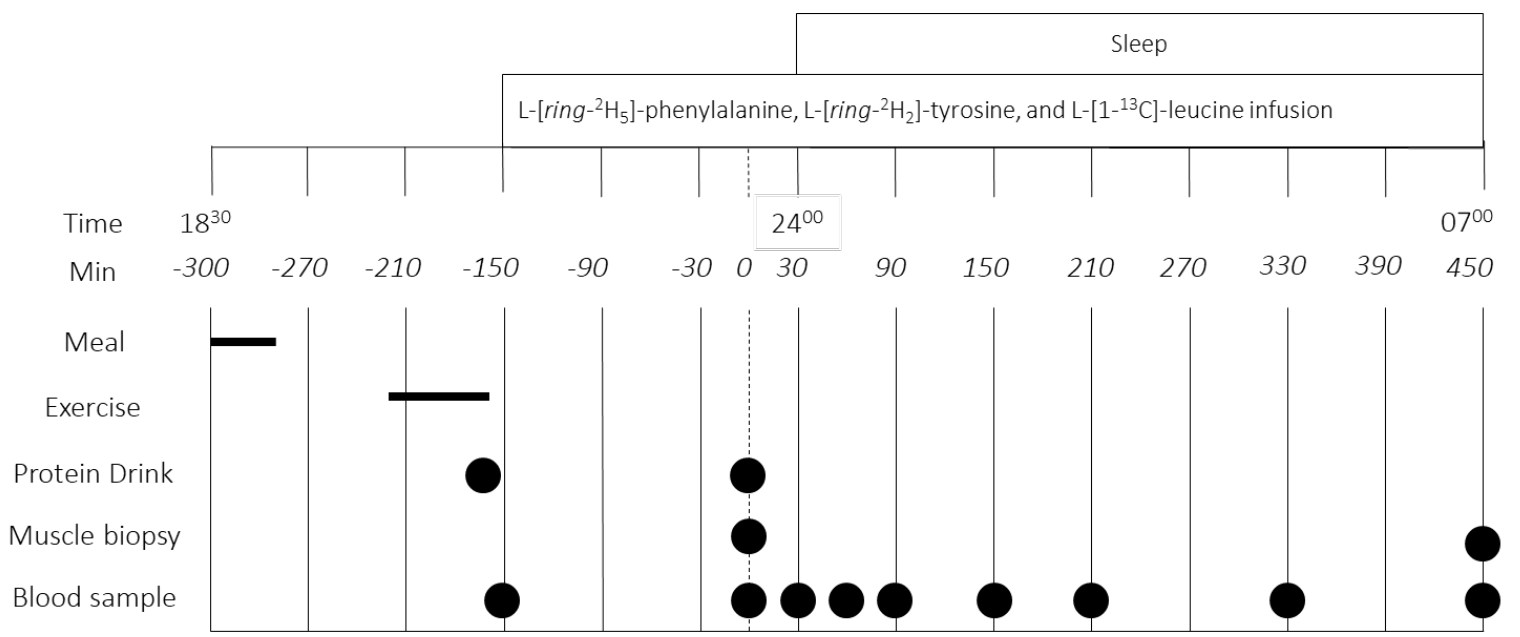

Figure 6.1. Experimental protocol. A drink with $20 \mathrm{~g}$ milk protein isolate and $45 \mathrm{~g}$ of carbohydrate was ingested at 20:45 $\mathrm{h}$ and a drink with $30 \mathrm{~g}$ intrinsically labeled casein protein was ingested at 23:30 h. Subjects were randomly assigned to perform a single bout of resistance-type exercise or to remain rested between 19:45 $\mathrm{h}$ and 20:45 $\mathrm{h}$.

\section{Exercise protocol}

The exercise protocol consisted of $60 \mathrm{~min}$ of lower-body resistance-type exercise. After $15 \mathrm{~min}$ of selfpaced cycling at $150 \mathrm{~W}$ with a cadence of $60-80 \mathrm{rpm}$, subjects performed 6 sets of 10 repetitions on the horizontal leg press machine (Technogym BV, Rotterdam, Netherlands) and 6 sets of 10 repetitions on the leg extension machine (Technogym BV). The first two sets of both exercises were performed at $55 \%$ and $65 \%$ of the subjects' 1 RM, respectively. Sets $3-6$ were performed at $75 \%$ of $1 \mathrm{RM}$ and there were 2-min rest intervals between all sets. Immediately after the exercise session, both the PRO and $\mathrm{PRO}+\mathrm{EX}$ group received drinks providing $20 \mathrm{~g}$ protein and $45 \mathrm{~g}$ carbohydrate (Gatorade G-series 03 Recover protein recovery shake, the Gatorade Company, Chicago, USA).

\section{Production of intrinsically labeled protein}

Intrinsically L-[1- $\left.{ }^{13} \mathrm{C}\right]$-phenylalanine and L-[1- $\left.{ }^{13} \mathrm{C}\right]$-leucine labeled casein protein was obtained during the constant infusion of L-[1- $\left.{ }^{13} \mathrm{C}\right]$-phenylalanine $\left(455 \mu \mathrm{mol} \cdot \mathrm{min}^{-1}\right)$ and L-[1- $\left.{ }^{13} \mathrm{C}\right]$-leucine $\left(200 \mu \mathrm{mol} \cdot \mathrm{min}^{-1}\right)$ maintained for $96 \mathrm{~h}$ in a lactating dairy cow. The milk was collected, processed, and fractionated into the casein protein concentrate as previously described $[20-22]$. The L-[1-13 C]-phenylalanine and L-[1${ }^{13} \mathrm{C}$-leucine enrichments in casein protein were measured by gas chromatography-combustion-isotope ratio mass spectrometry (GC-IRMS; MAT 252, Finnigan, Breman, Germany) and averaged 38.7 molar percent excess (MPE) and 9.3 MPE, respectively. The proteins met all chemical and bacteriological specifications for human consumption.

\section{Tracer preparation}

The stable isotope tracers $\mathrm{L}-\left[\right.$ ring $\left._{-}{ }^{2} \mathrm{H}_{5}\right]$-phenylalanine, $\mathrm{L}-\left[1-{ }^{13} \mathrm{C}\right]$-leucine and $\mathrm{L}-\left[\mathrm{ring}_{-}-{ }^{2} \mathrm{H}_{2}\right]$-tyrosine were purchased from Cambridge Isotopes (Andover, MA) and dissolved in $0.9 \%$ saline before infusion (Basic Pharma, Geleen, the Netherlands). Continuous intravenous infusions were performed using a calibrated IVAC 598 pump (San Diego, CA, USA).

\section{Plasma analysis}

Plasma glucose and insulin concentrations were analyzed using commercially available kits (GLUC3, Roche, Ref: 05168791 190, and Immunologic, Roche, Ref: 12017547 122, respectively). Plasma amino 
acid concentrations and enrichments were determined by gas chromatography-mass spectrometry analysis (GC-MS; Agilent 7890A GC/5975C; MSD, Wilmington, Delware, USA). Specifically, internal standards of $\left[\mathrm{U}-{ }^{13} \mathrm{C}_{6}\right]$-leucine, $\left[\mathrm{U}-{ }^{13} \mathrm{C}_{9}{ }^{15} \mathrm{~N}\right]$-phenylalanine, and $\left[\mathrm{U}-{ }^{13} \mathrm{C}_{9}{ }^{15} \mathrm{~N}\right]$-tyrosine were added to the samples. The plasma was deproteinized on ice with dry 5-sulfosalicylic acid. Free amino acids were purified using cation exchange chromatography (AG 50W-X8 resin; mesh size: 100-200 $\mu \mathrm{m}$, ionic form: hydrogen; Bio-Rad Laboratories, Hercules, USA). The purified amino acids were converted into tertbutyl dimethylsilyl (tert-BDMS) derivatives with MTBSTFA before analysis by GC-MS. The amino acid concentrations were determined using electron impact ionization by monitoring ions at mass/charge $(\mathrm{m} / \mathrm{z}) 302$ and 308 for unlabeled and $\left[\mathrm{U}_{-}{ }^{13} \mathrm{C}_{6}\right.$ ] labeled-leucine, 336 and 346 for unlabeled and $\left[\mathrm{U}-{ }^{13} \mathrm{C}_{9}{ }^{15} \mathrm{~N}\right]$ labeled-phenylalanine respectively, and 466 and 476 for unlabeled and $\left[\mathrm{U}-{ }^{13} \mathrm{C}_{9}{ }^{15} \mathrm{~N}\right.$-tyrosine, respectively. The plasma leucine, phenylalanine, and tyrosine ${ }^{13} \mathrm{C}$ and ${ }^{2} \mathrm{H}$ enrichments were determined using selective ion monitoring at $\mathrm{m} / \mathrm{z} 302$ and 303 for unlabeled and labeled $\left(1-{ }^{13} \mathrm{C}\right)$ leucine, respectively; $\mathrm{m} / \mathrm{z} 336,337$ and 341 for unlabeled and labeled $\left(1-{ }^{13} \mathrm{C}\right.$ and ring- $\left.^{2} \mathrm{H}_{5}\right)$ phenylalanine, respectively; $\mathrm{m} / \mathrm{z} 466,467,468$ and 470 for unlabeled and labeled $\left(1-{ }^{13} \mathrm{C}\right.$, ring- $3,5-{ }^{2} \mathrm{H}_{2}$, and ring- $\left.{ }^{2} \mathrm{H}_{4}\right)$ tyrosine, respectively. Standard regression curves were applied from a series of known standard enrichment values against the measured values to assess the linearity of the mass spectrometry and to account for any isotopic fractionation.

\section{Muscle analysis}

Myofibrillar protein enriched fractions were extracted from $\sim 60 \mathrm{mg}$ of wet muscle tissue by handhomogenizing on ice using a pestle in a standard extraction buffer $\left(7 \mu \mathrm{L} \cdot \mathrm{mg}^{-1}\right)$ [23]. The samples were spun at $2500 \mathrm{~g}$ and $4{ }^{\circ} \mathrm{C}$ for $5 \mathrm{~min}$. The pellet was washed with $500 \mu \mathrm{L} \mathrm{ddH} 2 \mathrm{O}$ and centrifuged at 250 $\mathrm{g}$ and $4{ }^{\circ} \mathrm{C}$ for $10 \mathrm{~min}$. The myofibrillar protein was solubilized by adding $1 \mathrm{~mL}$ of $0.3 \mathrm{M} \mathrm{NaOH}$ and heating at $50^{\circ} \mathrm{C}$ for $30 \mathrm{~min}$ with vortex mixing every $10 \mathrm{~min}$. Samples were centrifuged at $9500 \mathrm{~g}$ and $4{ }^{\circ} \mathrm{C}$ for $5 \mathrm{~min}$, the supernatant containing the myofibrillar proteins was collected and the collagen pellet was discarded. Myofibrillar proteins were precipitated by the addition of $1 \mathrm{~mL}$ of $1 \mathrm{M} \mathrm{PCA}$ and spinning at $700 \mathrm{~g}$ and $4{ }^{\circ} \mathrm{C}$ for $10 \mathrm{~min}$. The myofibrillar protein was washed twice with $70 \%$ ethanol and hydrolyzed overnight in $2 \mathrm{~mL}$ of $6 \mathrm{M} \mathrm{HCL}$ at $110^{\circ} \mathrm{C}$. The free amino acids from the hydrolyzed myofibrillar protein pellet were dried under nitrogen stream while being heated to $120^{\circ} \mathrm{C}$. The free amino acids were then dissolved in $25 \%$ acetic acid solution, passed over cation exchange AG $50 \mathrm{~W}$ X8 resin columns (mesh size: 100-200, ionic form: hydrogen; Bio-Rad Laboratories, Hercules, CA), and eluted with $2 \mathrm{M} \mathrm{NH}_{4} \mathrm{OH}$. The purified amino acids were divided into 2 aliquots to determine the L[ring- $\left.{ }^{2} \mathrm{H}_{5}\right]$-phenylalanine enrichments by GC-MS analysis and the L-[1-13 $\left.\mathrm{C}\right]$-phenylalanine and L-[1-13 C]leucine enrichments by gas chromatography-combustion-isotope ratio mass spectrometry (GC-IRMS) analysis. To reduce the signal-to-noise ratio during GC-MS analysis at low tracer enrichments, the phenylalanine from the myofibrillar protein hydrolysates was enzymatically decarboxylated to $\boldsymbol{\beta}$ phenylethylamine prior to derivatization with MTBSTFA. To determine myofibrillar protein $\mathrm{L}-\left[1-{ }^{13} \mathrm{C}\right]-$ phenylalanine and L- $\left[1-{ }^{13} \mathrm{C}\right]$-leucine enrichments by GC-IRMS analysis, the purified amino acids were converted into $\mathrm{N}$-ethoxycarbonyl ethyl ester derivatives with ethyl chloroformate (ECF). The derivatives were then measured by GC-IRMS (Finnigan MAT 253, Bremen, Germany) using a DB5-MS-column (no. 122-5532; Agilent J+W scientific GC Column), GC Isolink, and monitoring of ion masses 44, 45 and 46. Standard regression curves were applied to assess the linearity of the mass spectrometer and to account for isotopic fractionation. 


\section{Calculations}

Ingestion of L-[1- $\left.{ }^{13} \mathrm{C}\right]$-phenylalanine labeled protein, intravenous infusion of $\mathrm{L}-\left[\right.$ ring- $\left.^{2} \mathrm{H}_{5}\right]$-phenylalanine, and L-[ring-3,5- ${ }^{2} \mathrm{H}_{2}$ ]-tyrosine, and blood sample enrichment values were used to assess whole-body amino acid kinetics in non-steady state conditions. Total, exogenous, and endogenous phenylalanine rate of appearance $\left(R_{a}\right)$ and plasma availability of dietary protein-derived phenylalanine that appeared in the systemic circulation as a fraction of total amount of phenylalanine that was ingested (Phe plasma) were calculated using modified Steele's equations $[24,25]$.

These parameters were calculated as follows:

$$
\begin{aligned}
& \operatorname{Total} R_{a}=\frac{F-\left[p V \cdot C(t) \cdot \frac{d E_{i v}}{d t}\right]}{E_{i v}(t)} \\
& \operatorname{Exo} R_{a}=\frac{\operatorname{Total} R_{a} \cdot E_{p o}(t)+\left[p V \cdot C(t) \cdot \frac{d E_{p o}}{d t}\right]}{E_{\text {prot }}} \\
& \operatorname{Endo}_{a}=\operatorname{Total} R_{a}-\operatorname{Exo} R_{a}-\mathrm{F} \\
& \text { Phe }_{\text {plasma }}=\left(\frac{\mathrm{AUC}_{\text {ExoRa }}}{\text { Phe }_{\text {prot }}}\right) \cdot 100
\end{aligned}
$$

where $F$ is the intravenous tracer infusion rate $\left(\mu \mathrm{mol} \cdot \mathrm{kg}^{-1} \cdot \mathrm{min}^{-1}\right)$, and $p V\left(0.125 \mathrm{~L} \cdot \mathrm{kg}^{-1}\right)$ is the distribution volume for phenylalanine [25]. $C(t)$ is the mean plasma phenylalanine concentration between 2 consecutive time points. $d E_{i v} / d t$ represents the time-dependent variations of plasma phenylalanine enrichment derived from the intravenous tracer and $E_{i v}(t)$ is the mean plasma phenylalanine enrichment from the intravenous tracer between 2 consecutive time points. Exo $R_{a}$ represents the plasma entry rate of dietary phenylalanine, $E_{p o}(t)$ is the mean plasma phenylalanine enrichment for the ingested tracer, $d E_{p o} / d t$ represents the time-dependent variations of plasma phenylalanine enrichment derived from the oral tracer and $E_{\text {prot }}$ is the $\mathrm{L}-\left[1-{ }^{13} \mathrm{C}\right]$-phenylalanine enrichment in the dietary protein. Phe $e_{\text {plasma }}$ is the percentage of ingested dietary phenylalanine that becomes available in the plasma and is calculated using Phe prot and $A \cup C_{\text {ExoRa. }}$. Phe Prot is the amount of dietary phenylalanine ingested and $A U C_{\text {ExoRa }}$

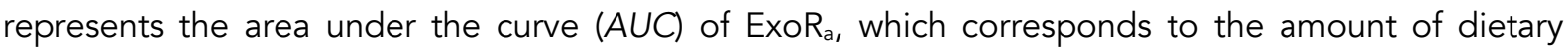
phenylalanine that appeared in the blood over a $7.5 \mathrm{~h}$ period following ingestion.

Total rate of disappearance of phenylalanine equals the rate of phenylalanine hydroxylation (first step in phenylalanine oxidation) and utilization for protein synthesis. This parameter is calculated as follows:

$$
\operatorname{TotalR}_{\mathrm{d}}=\operatorname{TotalR}_{\mathrm{a}}-\mathrm{pV} \cdot \frac{\mathrm{dC}}{\mathrm{dt}}
$$

Because whole-body $R_{d}$ comprises the rate of phenylalanine disappearance from the free amino acid pool in the blood due to protein synthesis and oxidation, whole-body protein synthesis can be calculated as $R_{d}$ minus oxidation. Whole-body phenylalanine oxidation can be determined from the conversion (hydroxylation) of $\mathrm{L}-\left[\right.$ ring $\left.^{-2} \mathrm{H}_{5}\right]$-phenylalanine to $\mathrm{L}-\left[\right.$ ring $\left.^{-}{ }^{2} \mathrm{H}_{4}\right]$-tyrosine. The rate of hydroxylation was calculated by using the following formula:

$$
\text { Phe }_{\text {hydroxylation }}=\operatorname{Tyr} R_{a} \cdot \frac{E_{\mathrm{t}}(\mathrm{t})}{\mathrm{E}_{\mathrm{p}}(\mathrm{t})} \cdot \frac{\mathrm{PheR}_{\mathrm{d}}}{\left(\mathrm{F}+\mathrm{PheR}_{\mathrm{d}}\right)}
$$


Tyr $R_{a}$ represents the rate of appearance of L-[ring- $\left.{ }^{2} \mathrm{H}_{4}\right]$-tyrosine; $E_{t}(t)$ and $E_{p}(t)$ are the L-[ring- $\left.{ }^{2} \mathrm{H}_{4}\right]-$ tyrosine and L-[ring- $\left.{ }^{2} \mathrm{H}_{5}\right]$-phenylalanine enrichments in plasma between 2 consecutive time points, respectively and $F$ is the infusion rate of phenylalanine. Whole-body protein synthesis was calculated using:

$$
\text { Protein Synthesis }=R_{d}-\text { Phe }_{\text {hydroxylation }}
$$

Whole-body protein net balance was calculated as AUC over the $7.5 \mathrm{~h}$ post-prandial phase using wholebody protein synthesis minus endogenous $R_{a}$.

$$
\text { Phe }_{\text {net balance }}=\text { Protein synthesis }-E_{\text {Endo }} \text { Ra }
$$

The fractional synthesis rate (FSR) of myofibrillar protein was calculated by dividing the increment in enrichment in the product, i.e. protein-bound $\mathrm{L}-\left[1-{ }^{13} \mathrm{C}\right]$-leucine or $\mathrm{L}-\left[\right.$ ring- $\left.-{ }^{2} \mathrm{H}_{5}\right]$-phenylalanine, by the enrichment of the respective precursor amino acid enrichments (i.e., plasma free amino acids). Weighted mean plasma L-[ring- $\left.{ }^{2} \mathrm{H}_{5}\right]$-phenylalanine and L-[1- $\left.{ }^{13} \mathrm{C}\right]$-leucine enrichments were used as the preferred precursor pools to estimate myofibrillar protein fractional synthesis rates from the continuously infused L-[ring- $\left.{ }^{2} \mathrm{H}_{5}\right]$-phenylalanine, and $\mathrm{L}-\left[1-{ }^{13} \mathrm{C}\right]$-leucine tracers. Consequently, myofibrillar FSR was calculated as follows [26]:

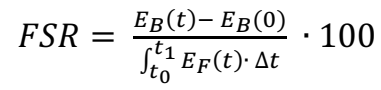

where $E_{B}$ represents muscle protein bound L-[ring $\left.-{ }^{2} \mathrm{H}_{5}\right]$-phenylalanine or $\mathrm{L}-\left[1-{ }^{13} \mathrm{C}\right]$-leucine. $E_{F}$ represent the average plasma $\mathrm{L}-\left[\mathrm{ring}_{-}{ }^{2} \mathrm{H}_{5}\right]$-phenylalanine or $\mathrm{L}-\left[1-{ }^{13} \mathrm{C}\right]$-leucine enrichment during the tracer incorporation period. $t$ Indicates the time interval (h) between biopsies.

\section{Sleep quality assessment}

The Pittsburg Sleep Quality Index (PSOI, Sleep Medicine Institute, University of Pittsburgh) was used to assess habitual sleep quality during pretesting [27]. PSOI scoring (global scores 0-21 points; higher scores indicate worse sleep quality) was used to classify all subjects to very good, good, poor or very poor sleepers. Subjects that scored $>5$ (poor sleepers) were not included in the trial. Sleep behavior during the test night was monitored using wrist activity monitors (Philips Respironics, Bend, USA). Additionally, the start and end time of sleep were recorded throughout the trial. The following parameters were derived from sleep records and activity monitors: sleep time (clock time), wake time (clock time), sleep onset latency (the period of time between bed time and sleep start), sleep duration (h), time awake/light sleep (h), sleep efficiency (\%, sleep duration expressed as a percentage of time in bed), and wake bouts.

\section{Statistics}

All data are expressed as means \pm SEM. A sample size of 12 subjects per group including a $10 \%$ dropout rate was calculated with a power of $80 \%$ and an a-level of .05 to detect a $20 \%$ difference in FSR between groups. Baseline characteristics between groups were compared using a Student's ttest. Time-dependent variables (i.e. plasma metabolite concentrations, plasma enrichments and 
whole-body protein kinetics) were analyzed by two-factor repeated measures ANOVA with time as within-subjects factor and treatment group as between-subjects factor. The analysis was carried out for the period starting at the time of protein administration, between $\mathrm{t}=0$ and $450 \mathrm{~min}$. Non timedependent variables (i.e. FSR values) were compared between treatment groups using Student's $t$ tests. Statistical significance was set at $P<0.05$. All calculations were performed using SPSS 21.0 (SPSS inc., Chicago, Illinois, USA). 


\section{RESULTS}

\section{Plasma analysis}

Plasma glucose and insulin concentrations are shown in Figure 6.2. Both plasma glucose and plasma insulin concentrations were slightly lower in the PRO-EX vs PRO group throughout the overnight period (treatment effect: $P<0.05)$. However, changes in plasma glucose and plasma insulin over time were not different between groups (time $x$ treatment interaction: $(P=0.476)$. Plasma insulin concentrations peaked at 30 min following protein ingestion at $9.1 \pm 2.2$ and $14.3 \pm 1.2 \mathrm{mU} \cdot \mathrm{L}^{-1}$ in the $\mathrm{PRO}$ and $\mathrm{PRO}+\mathrm{EX}$ treatment, respectively.
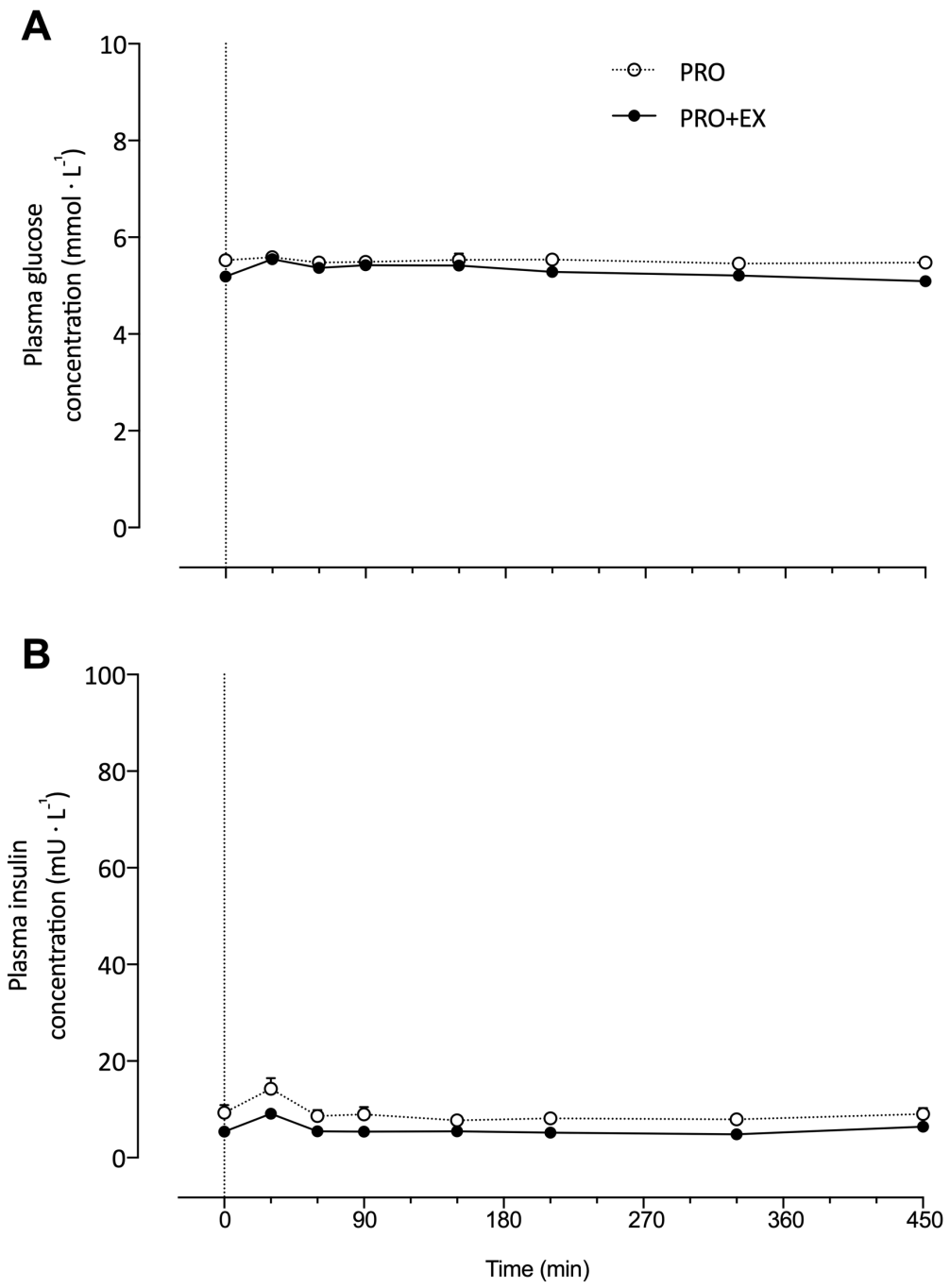

Figure 6.2. Overnight plasma glucose $\left(A, m m o l \cdot L^{-1}\right)$ and insulin concentrations $\left(B, m U \cdot L^{-1}\right)$ following protein ingestion with $(P R O+E X)$ and without (PRO) prior exercise. The dotted line represents the ingestion of the treatment. Values represent means \pm SEM. Data were analyzed with a two-way repeated-measures (time $x$ treatment) ANOVA. Glucose: time effect: $P=0.004$; treatment effect: $P=0.0077$; time $x$ treatment interaction: $P=0.075$. Insulin: time effect: $P<0.001$; treatment effect: $P=0.014$; time $x$ treatment interaction: $P=0.476$. 
Plasma phenylalanine (A), leucine (B), and tyrosine (C) concentrations are displayed in Figure 6.3. Plasma amino acid concentrations increased over time, with no significant differences in plasma phenylalanine and leucine concentrations between treatments (time $x$ treatment interaction: $P>0.05$ ). In contrast, a significant time $x$ treatment interaction was found for plasma tyrosine $(P=0.005)$.
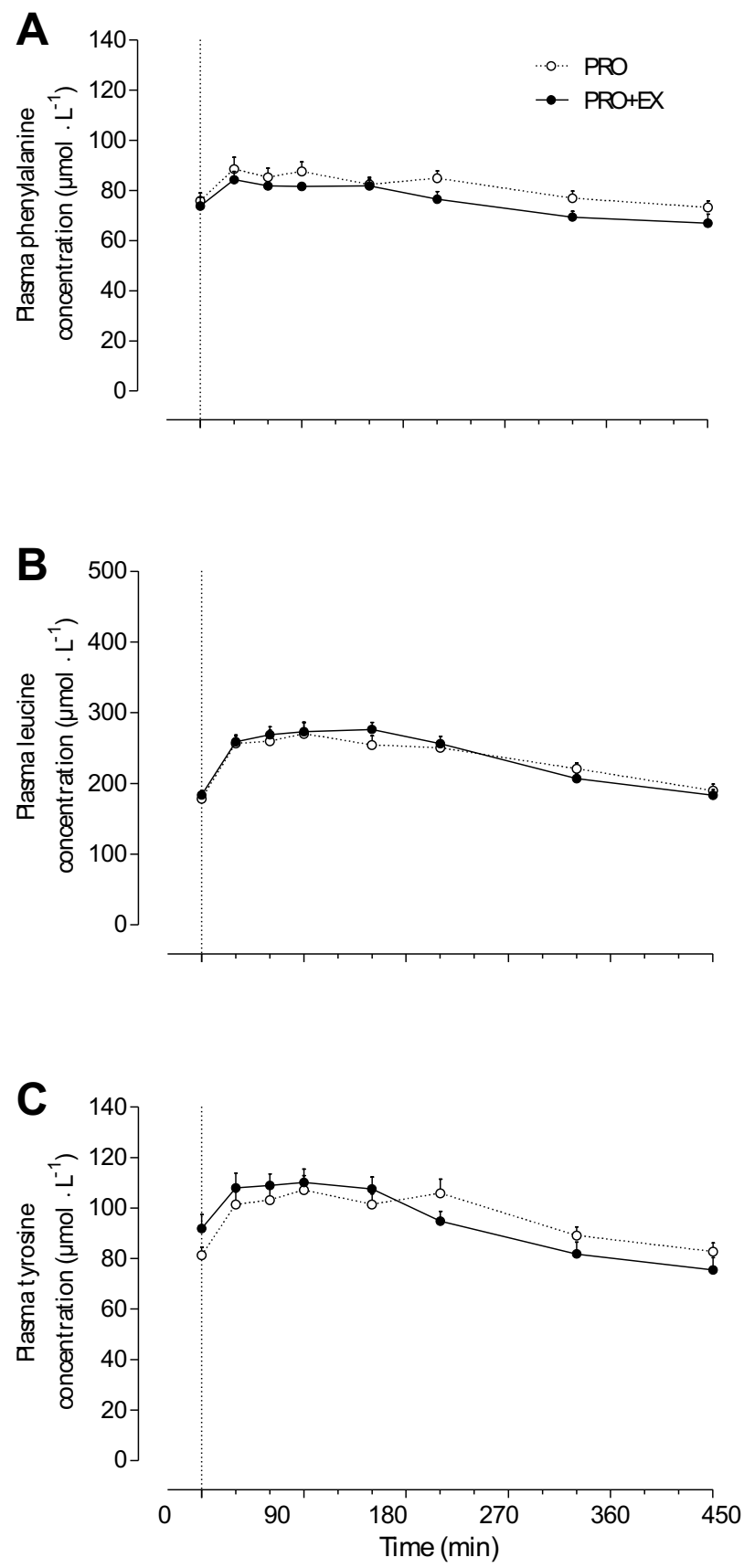

Figure 6.3. Overnight plasma phenylalanine (A), leucine (B) and tyrosine $(C)$ concentrations $\left(\mu \mathrm{mol} \cdot \mathrm{L}^{-1}\right)$. The dotted line represents the ingestion of the treatment. Values represent means \pm SEM. Data were analyzed with a two-way repeated-measures (time $x$ treatment) ANOVA. Phenylalanine: time effect: $P<0.001$; treatment effect: $P=0.212$; time $x$ treatment interaction: $P=0.275$. Leucine: time effect: $P<0.001$; treatment effect: $P=0.741$; time $\times$ treatment interaction: $P=0.524$. Tyrosine: time effect: $P<0.001$; treatment effect: $P=0.877$; time $\times$ treatment interaction: $P=0.005$. $P R O$ : pre-sleep protein ingestion without prior exercise, $\mathrm{PRO}+\mathrm{EX}$ : pre-sleep protein ingestion with prior exercise. 
Figure 6.4 shows the plasma L-[ring- $\left.-{ }^{2} \mathrm{H}_{5}\right]$-phenylalanine, L- $\left[1-{ }^{13} \mathrm{C}\right]$-leucine, and $\mathrm{L}-\left[1-{ }^{13} \mathrm{C}\right]$-phenylalanine enrichments (MPE). Plasma tracer enrichments did not differ between treatments before ingesting the protein ( $t=0 \mathrm{~min}, \mathrm{P}>0.05$ ). Following protein ingestion, plasma $\mathrm{L}-\left[\right.$ ring $\left.-{ }^{2} \mathrm{H}_{5}\right]$-phenylalanine and $\mathrm{L}-\left[1-{ }^{13} \mathrm{C}\right]-$ leucine enrichments increased slightly over time, but this increase over time did not differ between treatments (time $\mathrm{x}$ treatment interaction, $\mathrm{P}>0.05$ ). Plasma $\mathrm{L}-\left[1-{ }^{13} \mathrm{C}\right]$-phenylalanine enrichments, originating from the ingested protein, increased in both treatments, reaching maximal values of $9.39 \pm 0.42 \mathrm{MPE}$ at $\mathrm{t}=90 \mathrm{~min}$ in $\mathrm{PRO}$ and $9.89 \pm 0.44 \mathrm{MPE}$ at $\mathrm{t}=150 \mathrm{~min}$ in the PRO+EX treatment, and remained elevated above basal levels for the duration of the night with no differences over time between treatments (time $x$ treatment interaction: $P=0.365$ ).
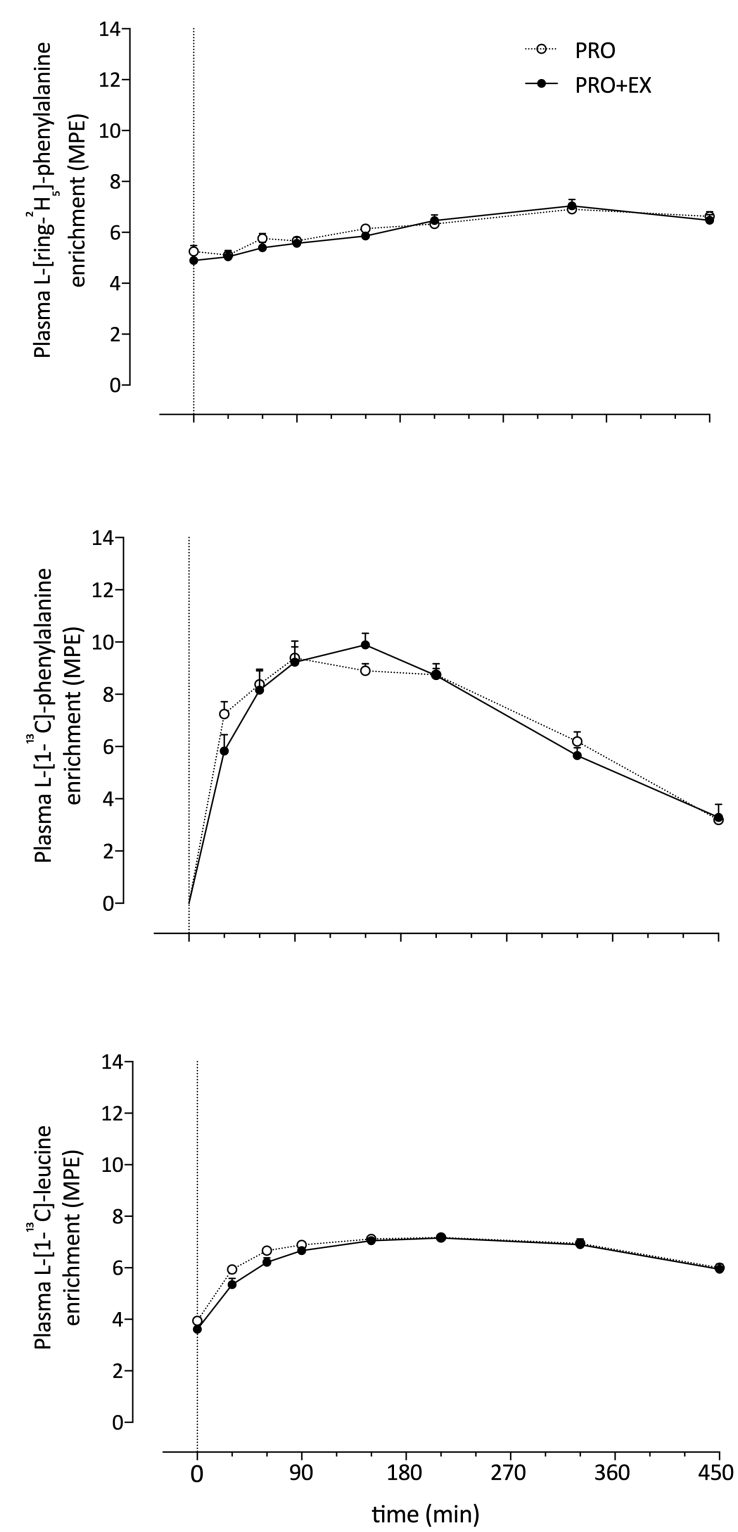

Figure 6.4. Overnight plasma L-[ring- $\left.{ }^{2} \mathrm{H}_{5}\right]$-phenylalanine $(A), L-\left[1-{ }^{13} \mathrm{C}\right]$-leucine $(B), \mathrm{L}-\left[1-{ }^{13} \mathrm{C}\right]$-phenylalanine $(C)$ enrichments in mole percent excess (MPE). The dotted line represents the ingestion of the treatment. Values represent means \pm SEM. Data were analyzed with repeated-measures (time $x$ treatment) ANOVA. L-[ring- $\left.{ }^{2} \mathrm{H}_{5}\right]$-phenylalanine enrichment: time effect: $P<0.001$; treatment effect: $P=0.530$; time $\times$ treatment interaction: $P=0.445 . L-\left[1-{ }^{13} \mathrm{C}\right]$-phenylalanine enrichment: time effect: $P<0.001$; treatment effect: $P=0.446$; time $\times$ treatment interaction: $P=0.365 . L-\left[1-{ }^{13} \mathrm{C}\right]$-leucine enrichment: time effect: $P<0.001$; treatment effect: $P=0.164$; time $x$ treatment interaction: $P=0.236$. $P R O$ : pre-sleep protein ingestion without prior exercise, $P R O+E X: p r e-$ sleep protein ingestion with prior exercise. 


\section{Whole-body amino acid kinetics}

Plasma amino acid kinetics data are presented in Figure 6.5. Exogenous phenylalanine appearance rates increased following protein ingestion with no differences between treatments (time $\mathrm{x}$ treatment interaction: $P=0.334$ ). Endogenous phenylalanine appearance rates declined following protein ingestion, with no differences between treatments (time $x$ treatment interaction: $P=0.179$ ). Over the entire $7.5 \mathrm{~h}$ post-prandial period, 59.0 \pm 1.8 and 55.8 $\pm 1.7 \%$ (PRO and PRO+EX, respectively) of the ingested dietary protein-bound phenylalanine appeared in the plasma circulation, with no differences between treatments $(P=0.205)$.

A

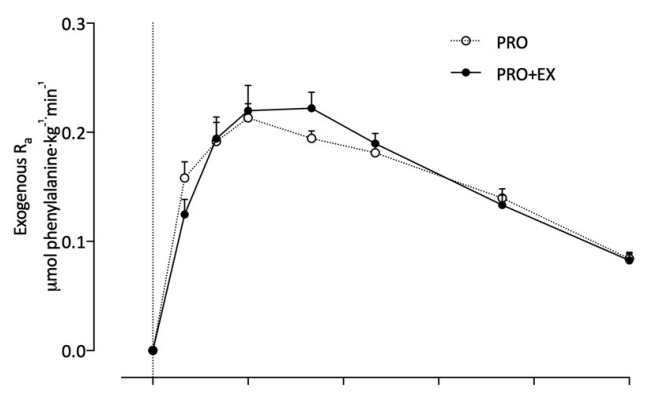

C

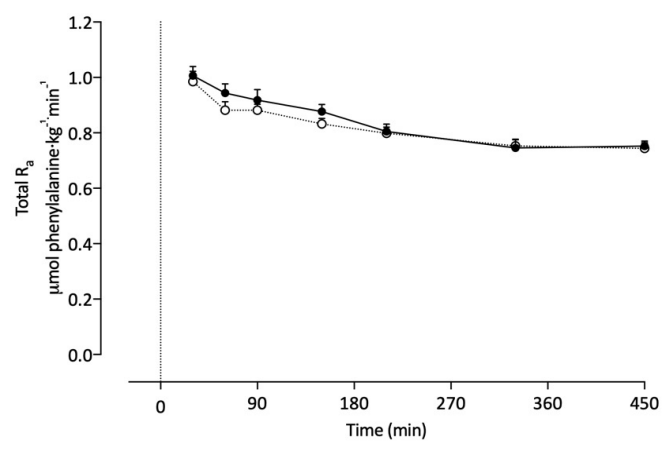

B

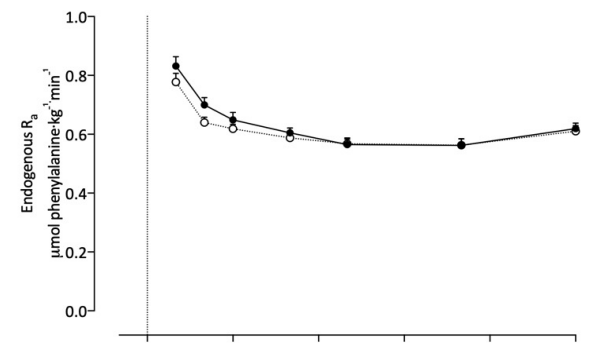

D



Figure 6.5. Overnight exogenous phenylalanine rate of appearance $\left(R_{a}\right)(A)$, endogenous phenylalanine $R_{a}(B)$, total phenylalanine $R_{a}(C)$, and total phenylalanine rate of disappearance $\left(R_{d}\right)(D)$. The dotted line represents the ingestion of the treatment. Values represent means $\pm S E M$. Data were analyzed with repeated-measures (time $x$ treatment) ANOVA. Exogenous phenylalanine $R_{a}$ : time effect: $P<0.001$; treatment effect: $P=0.957$; time $x$ treatment interaction: $P=0.334$. Endogenous phenylalanine $R_{a}$ : time effect: $P<0.001$; treatment effect: $P=0.368$; time $x$ treatment interaction: $P=0.179$. Total phenylalanine $R_{a}$ : time effect: $P<0.001$; treatment effect: $P=0.468$; time $x$ treatment interaction: $P=0.366$. Total phenylalanine Rd: time effect: $P<0.001$; treatment effect: $\mathrm{P}=0.421$; time $x$ treatment interaction: $\mathrm{P}=0.370$. $\mathrm{PRO}$ : pre-sleep protein ingestion without prior exercise, $\mathrm{PRO}+\mathrm{EX}$ : pre-sleep protein ingestion with prior exercise.

Whole-body protein metabolism data are expressed in Figure 6.6. Protein ingestion prior to sleep resulted in positive overnight whole-body protein net balance with no differences observed between treatments (PRO: $51.1 \pm 1.5$ vs PRO+EX: $53.0 \pm 1.9 \mu \mathrm{mol}$ phenylalanine $\cdot \mathrm{kg}^{-1} \cdot 7.5 \mathrm{~h}^{-1}, P=0.436$ ). Furthermore, resistance-type exercise did not appear to further influence any other parameters of whole-body protein metabolism. 


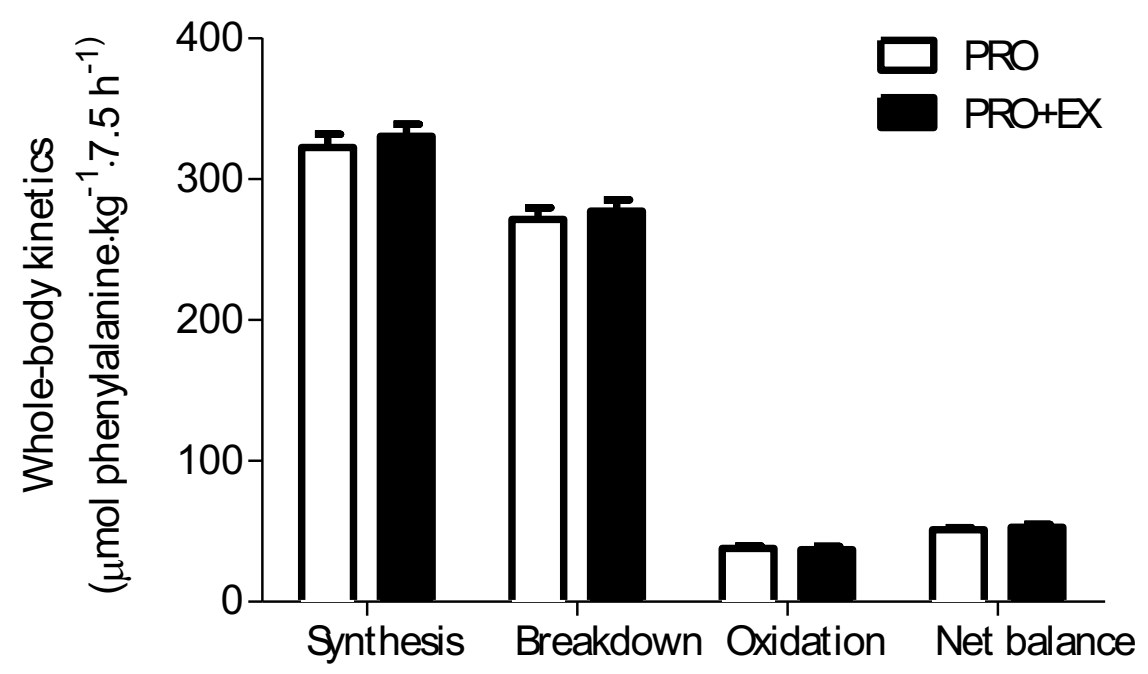

Figure 6.6. Calculated rates of overnight whole-body protein synthesis, breakdown, oxidation, and net protein balance ( $\mu$ mol phenylalanine $\left.\cdot \mathrm{kg}^{-1} \cdot 7.5 \mathrm{~h}^{-1}\right)$. Values represent means \pm SEM. Data were analyzed with a Student's $\mathrm{t}$-test. No significant differences were detected $(P>0.05)$. PRO: pre-sleep protein ingestion without prior exercise, $\mathrm{PRO}+\mathrm{EX}$ : pre-sleep protein ingestion with prior exercise.

\section{Myofibrillar protein fractional synthesis rates and protein-bound enrichments}

Myofibrillar protein fractional synthetic rates (FSR) based upon L-[ring- $\left.{ }^{2} \mathrm{H}_{5}\right]$-phenylalanine infusion with plasma L-[ring- $\left.{ }^{2} \mathrm{H}_{5}\right]$ enrichments as precursor $\left(\mathrm{A}: \mathrm{FSR}\right.$ in $\left.\% \cdot \mathrm{h}^{-1}\right)$ or using $\mathrm{L}-\left[1-{ }^{13} \mathrm{C}\right]$-leucine ingestion and infusion with plasma $L-\left[1-{ }^{13} \mathrm{C}\right]$-leucine enrichments as precursor $\left(B, F S R\right.$ in $\left.\% \cdot h^{-1}\right)$ are displayed in Figure 6.7. Exercise prior to protein ingestion before sleep resulted in greater stimulation of overnight myofibrillar FSR calculated based upon L-[ring- $\left.{ }^{2} \mathrm{H}_{5}\right]$-phenylalanine $\left(0.055 \pm 0.002\right.$ vs $0.040 \pm 0.003 \% \cdot h{ }^{-1}$, $P<0.001)$ as well as $L-\left[1-{ }^{13} \mathrm{C}\right]$-leucine $\left(0.073 \pm 0.004\right.$ vs $\left.0.055 \pm 0.006 \% \cdot h^{-1}, P=0.024\right)$. Overnight FSR were $37 \%$ or $31 \%$ higher in the PRO+EX compared with the PRO treatment, based upon L-[ring- $\left.{ }^{2} \mathrm{H}_{5}\right]-$ phenylalanine and $\mathrm{L}-\left[1-{ }^{13} \mathrm{C}\right]$-leucine infusion, respectively. Myofibrillar $\mathrm{L}-\left[1-{ }^{13} \mathrm{C}\right]$-phenylalanine enrichments (MPE) increased following the ingestion of intrinsically L- $\left[1-{ }^{13} \mathrm{C}\right]$-phenylalanine labeled protein, reaching values of $0.026 \pm 0.003$ vs $0.015 \pm 0.003$ MPE in the PRO+EX and PRO treatment, respectively $(P=0.012$; Figure $6.7 \mathrm{C})$.

\section{Sleep Data}

Sleep analysis data are presented in Table 6.2. Total sleep duration did not differ between the treatments (PRO: 6:05 $\pm 0: 10$ vs PRO+EX: 6:00 $\pm 0: 11$ (hh:mm), $P=0.794)$ ). In addition, there were no significant differences between the treatments in sleep time, wake time, sleep onset latency (the period of time between bedtime and sleep start), or sleep efficiency (\% sleep duration expressed as a percentage of time in bed). 
Table 6.2. Sleep analysis data

\begin{tabular}{|c|c|c|c|}
\hline & $\begin{array}{l}\text { PRO } \\
(n=11)\end{array}$ & $\begin{array}{c}P R O+E X \\
(n=12)\end{array}$ & $P$ \\
\hline Sleep time (hh:mm) & $23: 57 \pm 0: 03$ & $23: 57 \pm 0: 06$ & 0.896 \\
\hline Wake time (hh:mm) & $6: 47 \pm 0: 04$ & $6: 53 \pm 0: 07$ & 0.503 \\
\hline Sleep onset latency (hh:mm) & $0: 10 \pm 0: 03$ & $0: 11 \pm 0: 02$ & 0.805 \\
\hline Sleep duration (hh:mm) & $6: 05 \pm 0: 10$ & $6: 00 \pm 0: 11$ & 0.794 \\
\hline Time awake/Light sleep (hh:mm) & $0: 25 \pm 0: 05$ & $0: 30 \pm 0: 08$ & 0.617 \\
\hline Sleep efficiency (\%) & \pm 2 & \pm 3 & 0.530 \\
\hline Wake Bouts & $11 \pm 2$ & $11 \pm 2$ & 0.319 \\
\hline
\end{tabular}

Values are expressed as means \pm SEM. PRO: pre-sleep protein ingestion without prior exercise, PRO+EX: pre-sleep protein ingestion with prior exercise. Data were analyzed with Student's t-tests.
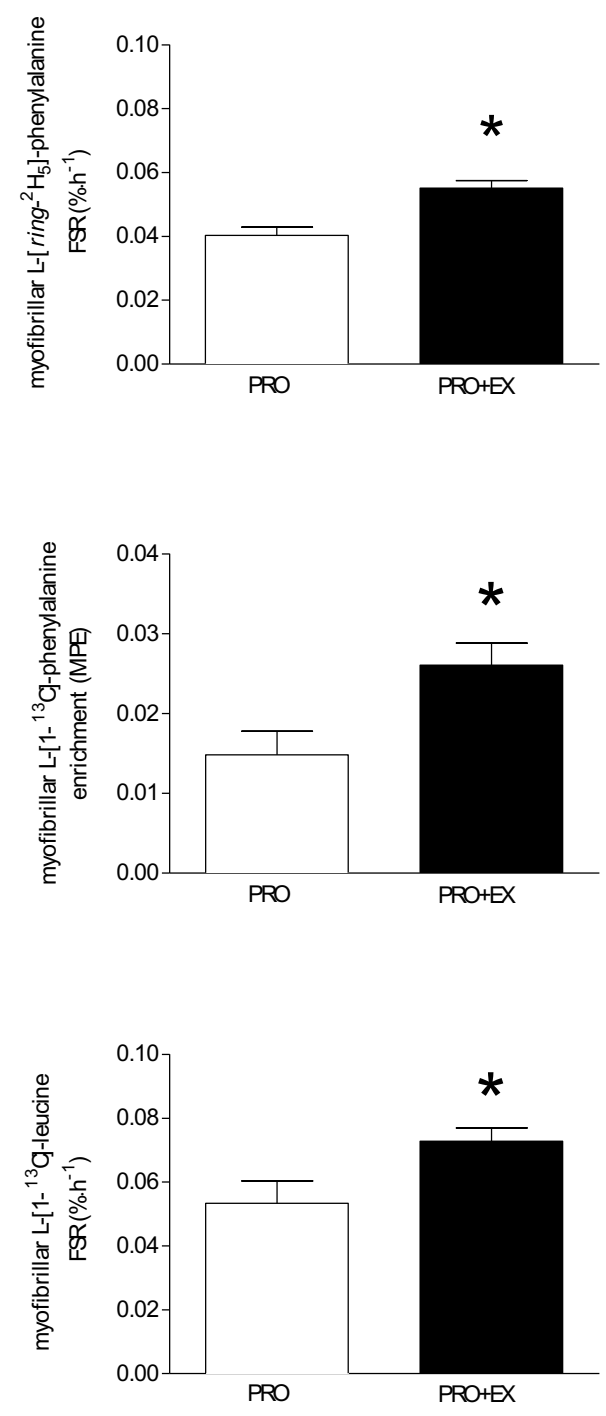

Figure 6.7. Overnight myofibrillar protein fractional synthetic rates (FSR) as calculated using L-[ring- $\left.{ }^{2} \mathrm{H}_{5}\right]-$ phenylalanine (A), or $\mathrm{L}-\left[1-{ }^{13} \mathrm{C}\right]$-leucine $(\mathrm{B})$ as tracer, and overnight $\mathrm{L}-\left[1-{ }^{13} \mathrm{C}\right]$-phenylalanine incorporation in myofibrillar protein (mole percent excess, MPE, C). Values represent means \pm SEM. Data were analyzed with a Student's t-test. *Significantly different from PRO $(P<0.05)$. PRO: pre-sleep protein ingestion without prior exercise, $\mathrm{PRO}+\mathrm{EX}$ : pre-sleep protein ingestion with prior exercise. 


\section{DISCUSSION}

The present study demonstrates that protein ingested prior to sleep is properly digested and absorbed, with $\sim 55 \%$ of the ingested protein-derived amino acids appearing in the systemic circulation throughout overnight sleep. Resistance-type exercise performed earlier in the evening increases myofibrillar protein synthesis rates during overnight sleep, and improves the efficiency by which the pre-sleep dietary protein-derived amino acids are directed towards overnight de novo myofibrillar protein synthesis.

In the present study we combined the ingestion of specifically produced intrinsically $\mathrm{L}-\left[1-{ }^{13} \mathrm{C}\right]-$ phenylalanine labeled protein with continuous intravenous infusion of $\mathrm{L}$-[ring- $\left.{ }^{2} \mathrm{H}_{5}\right]$-phenylalanine to allow us to assess dietary protein digestion and amino acid absorption kinetics during overnight sleep. Ingestion of $30 \mathrm{~g}$ casein protein was followed by proper protein digestion and subsequent amino acid absorption, as indicated by the post-prandial increase in plasma phenylalanine concentrations (Figure 6.3A) and L-[1- $\left.{ }^{13} \mathrm{C}\right]$-phenylalanine enrichments (Figure 6.4C). Exogenous dietary protein-derived phenylalanine appearance rates remained elevated throughout overnight sleep (Figure 6.5,), with $57 \pm 1 \%$ of the ingested protein-derived amino acids being released in the circulation over the entire $7.5 \mathrm{~h}$ overnight period. These data are in line with previous observations showing $~ 50 \%$ of ingested protein becoming available in the systemic circulation during a 5-7 h post-prandial period $[14,28,29]$. We extend upon our previous work, with the observation that resistance-type exercise performed earlier in the evening does not impair the digestion and absorption of protein ingested prior to sleep. We have previously shown that ingestion of $40 \mathrm{~g}$ protein prior to sleep increases whole-body protein synthesis, resulting in a positive protein net balance during overnight sleep [14]. In the current study, we observed that a more moderate $30 \mathrm{~g}$ protein dose likewise improves whole-body protein synthesis rates and allows for a positive whole-body protein net balance (Figure 6.6). Prior resistance-type exercise did not further modulate overnight whole-body protein synthesis, breakdown, amino acid oxidation or net balance following pre-sleep protein ingestion (Figure 6.6). As whole-body protein kinetics do not necessarily reflect skeletal muscle metabolism, we also collected muscle biopsies before and after overnight sleep to assess the impact of resistance-type exercise on the overnight muscle protein synthetic response to pre-sleep protein feeding.

As hypothesized, resistance-type exercise augmented overnight skeletal muscle reconditioning, with muscle protein synthesis rates being $37 \%\left(\mathrm{~L}-\left[\right.\right.$ ring- $\left.{ }^{2} \mathrm{H}_{5}\right]$-phenylalanine, Figure $\left.6.7 \mathrm{~A}\right)$ and $31 \%\left(\mathrm{~L}-\left[1-{ }^{13} \mathrm{C}\right]-\right.$ leucine, Figure 6.7B) higher in the exercise compared with the non-exercise control group. These data are in line with the greater anabolic response to protein ingestion following exercise observed in the morning after an overnight fast $[8,30,31]$. The present study extends upon these findings with the observation that resistance-type exercise increases the overnight muscle protein synthetic response to pre-sleep protein ingestion. In addition to the applied continuous infusions of L-[ring- $\left.{ }^{2} \mathrm{H}_{5}\right]$ phenylalanine and $\mathrm{L}-\left[1-{ }^{13} \mathrm{C}\right]$-leucine to measure myofibrillar protein synthesis rates, the ingestion of highly enriched $(>35 \%)$ intrinsically $\mathrm{L}-\left[1-{ }^{13} \mathrm{C}\right]$-phenylalanine labeled protein allowed us to also directly assess the metabolic fate of the pre-sleep dietary protein-derived amino acids. We were able to measure L-[1- $\left.{ }^{13} \mathrm{C}\right]$-phenylalanine enrichments in myofibrillar protein following pre-sleep protein ingestion (Figure 6.7C), demonstrating that the pre-sleep protein-provided amino acids as precursors for de novo myofibrillar protein synthesis during overnight sleep. Substantially more (76\%) more of the dietary protein-derived phenylalanine was incorporated in myofibrillar protein when resistance-type 
exercise was performed earlier in the evening. These data indicate that prior resistance-type exercise increases the efficiency by which pre-sleep protein-derived amino acids are directed towards de novo muscle protein synthesis during overnight sleep.

We have previously shown that protein ingestion before sleep increases muscle mass and strength gains during a 12-wk resistance-type exercise training program [15]. Our current data show that resistance-type exercise performed earlier in the evening enhances the muscle protein synthetic response to pre-sleep protein ingestion. Therefore, protein ingestion prior to sleep represents an effective strategy to augment overnight skeletal muscle reconditioning and is even more relevant on exercise training days.

In conclusion, resistance-type exercise performed in the evening augments the overnight muscle protein synthetic response to pre-sleep protein ingestion and allows more of the ingested proteinderived amino acids to be used for de novo myofibrillar protein synthesis during overnight sleep. Combing pre-sleep protein ingestion with resistance-type exercise represents an effective strategy to maximize overnight skeletal muscle reconditioning.

\section{ACKNOWLEDGEMENTS}

We acknowledge the enthusiastic support of the subjects who volunteered to participate in these experiments. The project is funded by $\mathrm{TI}$ Food and Nutrition, a public-private partnership on precompetitive research in food and nutrition. The researchers are responsible for the study design, data collection and analysis, decision to publish, and preparation of the manuscript. The industrial partners have contributed to the project through regular discussion. lan Rollo is an employee of the Gatorade Sports Science Institute, a division of PepsiCo Inc. The views expressed in this manuscript are those of the authors and do not necessarily reflect the position or policy of Pepsico Inc. The other authors report no conflict of interest. The results of the present study do not constitute endorsement by the American College of Sports Medicine. 


\section{REFERENCES}

1. Phillips SM, Tipton KD, Aarsland A, Wolf SE, Wolfe RR. Mixed muscle protein synthesis and breakdown after resistance exercise in humans. Am J Physiol. 1997;273:E99-107.

2. Biolo G, Maggi SP, Williams BD, Tipton KD, Wolfe RR. Increased rates of muscle protein turnover and amino acid transport after resistance exercise in humans. Am J Physiol. 1995;268:E514-20.

3. Tipton KD, Ferrando AA, Williams BD, Wolfe RR. Muscle protein metabolism in female swimmers after a combination of resistance and endurance exercise. J Appl Physiol (1985). 1996;81:20348.

4. Biolo G, Tipton KD, Klein S, Wolfe RR. An abundant supply of amino acids enhances the metabolic effect of exercise on muscle protein. Am J Physiol. 1997;273:E122-9.

5. Borsheim E, Tipton KD, Wolf SE, Wolfe RR. Essential amino acids and muscle protein recovery from resistance exercise. Am J Physiol Endocrinol Metab. 2002;283:E648-57.

6. Koopman R, Walrand S, Beelen M, Gijsen AP, Kies AK, Boirie Y, et al. Dietary protein digestion and absorption rates and the subsequent postprandial muscle protein synthetic response do not differ between young and elderly men. J Nutr. 2009;139:1707-13.

7. Moore DR, Robinson MJ, Fry JL, Tang JE, Glover El, Wilkinson SB, et al. Ingested protein dose response of muscle and albumin protein synthesis after resistance exercise in young men. Am J Clin Nutr. 2009;89:161-8.

8. Witard OC, Jackman SR, Breen L, Smith K, Selby A, Tipton KD. XMyofibrillar muscle protein synthesis rates subsequent to a meal in response to increasing doses of whey protein at rest and after resistance exercise. Am J Clin Nutr. 2014;99:86-95.

9. Tang JE, Moore DR, Kujbida GW, Tarnopolsky MA, Phillips SM. Ingestion of whey hydrolysate, casein, or soy protein isolate: effects on mixed muscle protein synthesis at rest and following resistance exercise in young men. J Appl Physiol (1985). 2009;107:987-92.

10. Wilkinson SB, Tarnopolsky MA, Macdonald MJ, Macdonald JR, Armstrong D, Phillips SM. Consumption of fluid skim milk promotes greater muscle protein accretion after resistance exercise than does consumption of an isonitrogenous and isoenergetic soy-protein beverage. Am J Clin Nutr. 2007;85:1031-40.

11. Areta JL, Burke LM, Ross ML, Camera DM, West DWD, Broad EM, et al. Timing and distribution of protein ingestion during prolonged recovery from resistance exercise alters myofibrillar protein synthesis. J Physiol. 2013;591:2319-31.

12. Levenhagen DK, Gresham JD, Carlson MG, Maron DJ, Borel MJ, Flakoll PJ. Postexercise nutrient intake timing in humans is critical to recovery of leg glucose and protein homeostasis. Am J Physiol Endocrinol Metab. 2001;280:E982-93.

13. Groen BBL, Res PT, Pennings B, Hertle E, Senden JMG, Saris WHM, et al. Intragastric protein administration stimulates overnight muscle protein synthesis in elderly men. Am J Physiol Endocrinol Metab. 2012;302:E52-60.

14. Res PT, Groen B, Pennings B, Beelen M, Wallis GA, Gijsen AP, et al. Protein ingestion before sleep improves postexercise overnight recovery. Medicine \& Science in Sports \& Exercise. 2012;44:1560-9.

15. Snijders T, Res PT, Smeets JSJ, van Vliet S, van Kranenburg J, Maase K, et al. Protein Ingestion before Sleep Increases Muscle Mass and Strength Gains during Prolonged Resistance-Type Exercise Training in Healthy Young Men. J Nutr. 2015;145:1178-84. 
16. Jones PR, Pearson J. Anthropometric determination of leg fat and muscle plus bone volumes in young male and female adults. J Physiol. 1969;204:63P-66P.

17. Mayhew JL, Prinster JL, Ware JS, Zimmer DL, Arabas JR, Bemben MG. Muscular endurance repetitions to predict bench press strength in men of different training levels. J Sports Med Phys Fitness. 1995;35:108-13.

18. Beelen M, Tieland M, Gijsen AP, Vandereyt $H$, Kies AK, Kuipers $H$, et al. Coingestion of carbohydrate and protein hydrolysate stimulates muscle protein synthesis during exercise in young men, with no further increase during subsequent overnight recovery. J Nutr. 2008;138:2198-204.

19. Bergstrom J. Percutaneous needle biopsy of skeletal muscle in physiological and clinical research. Scand. J. Clin. Lab. Invest. 1975;35:609-16.

20. Burd NA, Hamer HM, Pennings B, Pellikaan WF, Senden JMG, Gijsen AP, et al. Substantial Differences between Organ and Muscle Specific Tracer Incorporation Rates in a Lactating Dairy Cow. PLoS One. 2013;8:e68109.

21. Pennings B, Pellikaan WF, Senden JMG, van Vuuren AM, Sikkema J, van Loon LJC. The production of intrinsically labeled milk and meat protein is feasible and provides functional tools for human nutrition research. J Dairy Sci. 2011;94:4366-73.

22. van Loon LJC, Boirie Y, Gijsen AP, Fauquant J, de Roos AL, Kies AK, et al. The production of intrinsically labeled milk protein provides a functional tool for human nutrition research. J Dairy Sci. 2009;92:4812-22.

23. Koopman R, Zorenc AHG, Gransier RJJ, Cameron-Smith D, van Loon LJC. Increase in S6K1 phosphorylation in human skeletal muscle following resistance exercise occurs mainly in type II muscle fibers. Am J Physiol Endocrinol Metab. 2006;290:E1245-52.

24. Dangin M, Guillet C, Garcia-Rodenas C, Gachon P, Bouteloup-Demange C, Reiffers-Magnani K, et al. The rate of protein digestion affects protein gain differently during aging in humans. $\mathrm{J}$ Physiol. 2003;549:635-44.

25. Boirie Y, Gachon P, Corny S, Fauquant J, Maubois JL, Beaufrere B. Acute postprandial changes in leucine metabolism as assessed with an intrinsically labeled milk protein. Am J Physiol. 1996;271:E1083-91.

26. Kouw IWK, Gorissen SHM, Burd NA, Cermak NM, Gijsen AP, van Kranenburg J, et al. Postprandial Protein Handling Is Not Impaired in Type 2 Diabetes Patients When Compared With Normoglycemic Controls. J Clin Endocrinol Metab. 2015;100:3103-11.

27. Buysse DJ, Reynolds CF3, Monk TH, Berman SR, Kupfer DJ. The Pittsburgh Sleep Quality Index: a new instrument for psychiatric practice and research. Psychiatry Res. 1989;28:193-213.

28. Gorissen SHM, Burd NA, Kramer IF, van Kranenburg J, Gijsen AP, Rooyackers O, et al. Coingesting milk fat with micellar casein does not affect postprandial protein handling in healthy older men. Clin Nutr. 2015.

29. Groen BBL, Horstman AM, Hamer HM, de Haan M, van Kranenburg J, Bierau J, et al. PostPrandial Protein Handling: You Are What You Just Ate. Thompson D, editor. PLoS One. 2015;10:e0141582-22.

30. Pennings B, Koopman R, Beelen M, Senden JMG, Saris WHM, van Loon LJC. Exercising before protein intake allows for greater use of dietary protein-derived amino acids for de novo muscle protein synthesis in both young and elderly men. Am J Clin Nutr. American Society for Nutrition; 2011;93:322-31. 
31. Robinson MJ, Burd NA, Breen L, Rerecich T, Yang Y, Hector AJ, et al. Dose-dependent responses of myofibrillar protein synthesis with beef ingestion are enhanced with resistance exercise in middle-aged men. Appl. Physiol. Nutr. Metab. 2013;38:120-5. 



\section{Chapter 7}

Pre-sleep dietary protein-derived amino acids are incorporated in myofibrillar protein during postexercise overnight recovery

Jorn Trommelen; Imre W.K. Kouw; Andrew M. Holwerda; Tim Snijders; Shona L. Halson; Ian Rollo; Lex B. Verdijk ; Luc J.C. van Loon 


\section{ABSTRACT}

Purpose: To determine the impact of ingesting $30 \mathrm{~g}$ casein protein with and without $2 \mathrm{~g}$ free leucine prior to sleep on myofibrillar protein synthesis rates during post-exercise overnight recovery.

Methods: 36 healthy young males performed a single bout of resistance-type exercise in the evening (19:45 h) after a full day of dietary standardization. Thirty min prior to sleep (23:30 h), subjects ingested $30 \mathrm{~g}$ intrinsically L- $\left[1-{ }^{13} \mathrm{C}\right]$-phenylalanine-labeled protein with (PRO+leu, $\left.n=12\right)$ or without (PRO, $n=12$ ) $2 \mathrm{~g}$ free leucine, or a noncaloric placebo (PLA, $n=12$ ). Continuous intravenous L-[ring- $\left.{ }^{2} \mathrm{H}_{5}\right]-$ phenylalanine, L-[1-13 $\mathrm{C}]$-leucine and L-[ring- $\left.{ }^{2} \mathrm{H}_{2}\right]$-tyrosine infusions were applied. Blood and muscle tissue samples were collected to assess whole-body protein net balance, myofibrillar protein synthesis rates and overnight incorporation of dietary protein-derived amino acids into myofibrillar protein.

Results: Protein ingestion prior to sleep improved overnight whole-body protein net balance $(P<0.001)$. Myofibrillar protein synthesis rates did not differ significantly between treatments as assessed by L[ring- ${ }^{2} \mathrm{H}_{5}$ ]-phenylalanine $\left(0.057 \pm 0.002,0.055 \pm 0.002\right.$, and $0.055 \pm 0.004 \% \cdot h^{-1}$ for PLA, PRO, and $\mathrm{PRO}+$ leu, respectively; $\mathrm{P}=0.850)$ or $\mathrm{L}-\left[1-{ }^{13} \mathrm{C}\right]$-leucine $\left(0.080 \pm 0.004,0.073 \pm 0.004\right.$, and $0.083 \pm 0.006 \% \cdot \mathrm{h}^{-}$ 1 , respectively; $P=0.328)$. Myofibrillar $L-\left[1-{ }^{13} \mathrm{C}\right]$-phenylalanine enrichments increased following protein ingestion, but did not differ between the PRO and PRO+leu treatments.

Conclusion: Protein ingestion prior to sleep improves whole-body protein net balance and provides amino acids that are incorporated into myofibrillar protein during sleep. However, the ingestion of 30 $\mathrm{g}$ casein protein with or without additional free leucine prior to sleep does not increase muscle protein synthesis rates during post-exercise overnight recovery. 


\section{INTRODUCTION}

A single session of resistance-type exercise stimulates both muscle protein synthesis and breakdown rates [1-3]. Protein ingestion after exercise stimulates muscle protein synthesis and inhibits muscle protein breakdown, resulting in net muscle protein accretion during the acute stages of post-exercise recovery [4-6]. Therefore, post-exercise protein ingestion is widely applied as a strategy to increase post-exercise muscle protein synthesis rates and, as such, to stimulate post-exercise recovery and facilitate skeletal muscle reconditioning. Various factors have been identified that can modulate the post-exercise muscle protein synthetic response including the amount $[7,8]$, type $[9,10]$, leucine content $[11,12]$ and timing $[13,14]$ of protein ingestion.

In general, most studies assess the effect of food intake on the muscle protein synthetic response to exercise performed in an overnight fasted state. Such postabsorptive conditions differ from normal everyday practice in which recreational sports activities are performed in the late afternoon or evening after a full day of habitual physical activity and food intake. We have previously shown that protein ingestion after a bout of resistance-type exercise performed in the evening increases whole-body protein synthesis rates during the first few hours of recovery, but does not increase mixed muscle protein synthesis rates throughout overnight sleep [15]. In a follow-up, proof-of-principle study, we demonstrated that casein protein ingested immediately prior to sleep allows protein-derived amino acids to be released in the circulation, thereby stimulating mixed muscle protein synthesis during overnight sleep [16].

It has been well established that the ingestion of $20 \mathrm{~g}$ protein is sufficient to maximize muscle protein synthesis rates during the acute stage of post-exercise recovery in young adults $[7,8]$. This is considerably less than the $40 \mathrm{~g}$ casein protein we provided prior to sleep to increase muscle protein synthesis rates throughout overnight sleep [16]. Furthermore, we have recently reported that well-

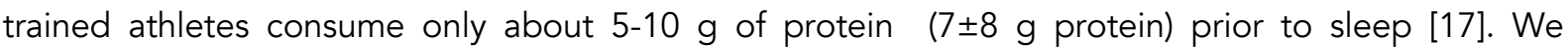
questioned whether a more moderate amount $(<40 \mathrm{~g})$ of protein can significantly increase muscle protein synthesis rates during overnight recovery. We hypothesized that pre-sleep ingestion of $30 \mathrm{~g}$ dietary protein increases post-exercise overnight muscle protein synthesis rates and provides amino acids that are incorporated into myofibrillar protein during overnight sleep. In addition, we hypothesized that leucine co-ingestion would further enhance the muscle protein synthetic response to the ingestion of $30 \mathrm{~g}$ protein prior to sleep.

In the present study, we tested our hypotheses by selecting 36 healthy young subjects who ingested $30 \mathrm{~g}$ casein protein with (PRO+leu) or without (PRO) an additional $2 \mathrm{~g}$ of crystalline leucine, or a placebo (PLA) before going to sleep. By combining contemporary stable isotope methodology with the ingestion of intrinsically L-[1-1 $\left.{ }^{13} \mathrm{C}\right]$-phenylalanine and L- $\left[1-{ }^{13} \mathrm{C}\right]$-leucine labeled protein we were able to assess i) the postprandial release of dietary protein-derived amino acids into the circulation, ii) their impact on overnight whole-body protein kinetics, iii) myofibrillar muscle protein synthesis rates, and iv) the incorporation of dietary protein-derived amino acids into muscle protein during overnight sleep [18-20]. 


\section{METHODS}

\section{Subjects}

A total of 36 healthy, recreationally active, young men (age: $23 \pm 1$ y; BMI: $22.6 \pm 0.3 \mathrm{~kg} \cdot \mathrm{m}^{-2}$, participating in exercise other than structured resistance-type exercise training, for 1-3 $d \cdot w^{-1}$ for $\geq 12$ months) were selected to participate in this study. Subjects' characteristics are presented in Table 7.1. Subjects were randomly assigned to ingest a placebo (PLA), $30 \mathrm{~g}$ casein protein (PRO), or $30 \mathrm{~g}$ casein protein plus 2 $g$ of crystalline leucine (PRO+leu) before going to sleep. The experiments were performed in a randomized, double blind manner. All subjects were fully informed of the nature and possible risks of the experimental procedures before their written informed consent was obtained. This study is part of a greater project investigating the impact of pre-sleep protein feeding on overnight muscle protein synthesis. The project was registered at Netherlands Trial Register as NTR3885, was approved by the Medical Ethical Committee of the Maastricht University Medical Centre, The Netherlands and conformed to standards for the use of human subjects in research as outlined in the most recent version of the Helsinki Declaration.

Table 7.1. Subjects' characteristics

\begin{tabular}{|c|c|c|c|c|c|c|c|c|c|}
\hline \multirow[b]{2}{*}{ Age $(y)$} & \multicolumn{3}{|c|}{$\begin{array}{c}\text { PLA } \\
(n=12)\end{array}$} & \multicolumn{3}{|c|}{$\begin{array}{c}\text { PRO } \\
(n=12)\end{array}$} & \multicolumn{3}{|c|}{$\begin{array}{c}\text { PRO+leu } \\
(n=12)\end{array}$} \\
\hline & 24 & \pm & 1 & 23 & \pm & 1 & 23 & \pm & 1 \\
\hline Weight (kg) & 75.4 & \pm & 2.3 & 73.0 & \pm & 1.7 & 72.7 & \pm & 2.2 \\
\hline $\mathrm{BMI}\left(\mathrm{kg} \cdot \mathrm{m}^{-2}\right)$ & 22.7 & \pm & 0.6 & 22.1 & \pm & 0.5 & 22.9 & \pm & 0.4 \\
\hline Fat (\%) & 15 & \pm & 1 & 14 & \pm & 1 & 14 & \pm & 1 \\
\hline Lean Body Mass (kg) & 61.2 & \pm & 1.8 & 59.5 & \pm & 1.6 & 63.7 & \pm & 1.4 \\
\hline Leg volume (L) & 9.1 & \pm & 0.3 & 9.0 & \pm & 0.3 & 9.3 & \pm & 0.4 \\
\hline
\end{tabular}

Values represent means \pm SEM. PLA: placebo, PRO: $30 \mathrm{~g}$ dietary protein, PRO+leu: $30 \mathrm{~g}$ dietary protein plus $2 \mathrm{~g}$ crystalline leucine. BMI: body mass index. Data were analyzed with a one-way ANOVA. There were no differences between treatments.

\section{Pretesting}

During screening, body weight and body composition (fat and fat-free mass) were determined by DEXA (Dual-energy X-ray absorptiometry, DEXA; Discovery A; Hologic, Bedford, USA). Leg volume was determined by anthropometry measurements as described by Jones and Pearson [21]. The subjects were then familiarized with the resistance-type exercise protocol and the exercise equipment. All exercises during pretesting and experimental trials were supervised by trained personnel. Subjects started by performing a 10-min cycling warm-up at $150 \mathrm{~W}$ before completing an estimation of their $1 \mathrm{RM}$ on the leg press and leg extension exercises using the multiple repetitions testing procedure [22]. For each exercise, subjects performed 10 submaximal repetitions to become familiarized with the equipment and to have lifting technique critiqued and properly adjusted. Sets were then performed at progressively increasing loads until failure to perform a valid estimation within 3-6 repetitions of the set. A repetition was valid if the subject was able to complete the entire lift in a controlled manner without assistance. A 2 min resting period between subsequent attempts was allowed. The pretesting and experimental trials were separated by at least $7 \mathrm{~d}$. 


\section{Diet and physical activity}

All subjects were instructed to refrain from exhaustive physical labor and exercise and to keep their diet as constant as possible $2 \mathrm{~d}$ before the experimental day. Food intake and physical activity questionnaires were collected for $2 \mathrm{~d}$ prior to the experiment. All subjects received a standardized diet throughout the experimental day $\left(0.16 \mathrm{MJ} \mathrm{kg}^{-1}\right.$, providing 62 energy percentage (En\%) carbohydrate, $13 \mathrm{En} \%$ protein, and $22 \mathrm{En} \%$ fat). The energy content of the standardized diet was based upon individual energy requirements based upon the Harris-Benedict equation and adjusted using a physical activity factor of 1.6 to ensure ample energy intake. During the experimental day, all participants ingested $1.2 \pm 0.01 \mathrm{~g}$ protein $\cdot \mathrm{kg}$ bodyweight ${ }^{-1}$ via the standardized diet with an additional $20 \mathrm{~g}$ $\left(0.28 \pm 0.01 \mathrm{~g} \mathrm{~kg}^{-1}\right)$ of protein provided immediately after cessation of exercise $(20: 45 \mathrm{~h})$. The PRO and PRO+leu treatments ingested an additional $30 \mathrm{~g}\left(0.42 \pm 0.01 \mathrm{~g} \cdot \mathrm{kg}^{-1}\right)$ of protein immediately prior to sleep (23:30 h). Prior to intake of the test drink and in the morning after the intervention, hunger ratings were assessed using the visual analogue scale (VAS) [23]. In the morning, subjects were invited to an ad libitum breakfast and food intake at breakfast was recorded for all subjects.

\section{Experimental Protocol}

An outline of the study protocol is provided in Figure 7.1. At 17:30 h, participants reported to the lab and had Teflon catheters inserted into the antecubital veins of each arm. At 18:30 h ( $t=-300 \mathrm{~min}$ ), all the subjects consumed a standardized dinner (Sligro, Maastricht, the Netherlands) under supervision (0.04 MJ. $\mathrm{kg}^{-1}$, providing $55 \mathrm{En} \%$ carbohydrate, $21 \mathrm{En} \%$ protein, and $20 \mathrm{En} \%$ fat), after which no more solid food was consumed. A single bout of resistance type-exercise was performed between 19:45 and 20:45 h. Drinks providing $20 \mathrm{~g}$ milk protein and $45 \mathrm{~g}$ carbohydrates were ingested immediately after exercise, which were ingested within $2 \mathrm{~min}$. The purpose of this recovery drink was to optimize muscle protein synthesis rates in the early stages of recovery $[7,15,24]$. Following protein ingestion, a background blood sample was taken prior to the initiation of the tracer infusion protocol, which was started at 21:00 h ( $t=-150 \mathrm{~min})$. The plasma and intracellular phenylalanine and leucine pools were primed with a single intravenous dose (priming dose) of L-[ring- $\left.{ }^{2} \mathrm{H}_{5}\right]$-phenylalanine $\left(2.0 \mu \mathrm{mol} \cdot \mathrm{kg}^{-1}\right), \mathrm{L}$ [ring- $\left.{ }^{2} \mathrm{H}_{2}\right]$-tyrosine $\left(0.615 \mu \mathrm{mol} \cdot \mathrm{kg}^{-1}\right)$, and $\mathrm{L}-\left[1{ }^{13} \mathrm{C}\right]$-leucine $\left(4.0 \mu \mathrm{mol} \cdot \mathrm{kg}^{-1}\right)$. Once primed, the continuous stable isotope infusion was initiated (infusion rate: $0.05 \mu \mathrm{mol}^{\prime} \mathrm{kg}^{-1} \cdot \mathrm{min}^{-1} \mathrm{~L}$-[ring- $\left.{ }^{2} \mathrm{H}_{5}\right]$-phenylalanine, 0.015 $\mu \mathrm{mol} \cdot \mathrm{kg}^{-1} \cdot \mathrm{min}^{-1} \quad \mathrm{~L}-\left[r_{i n g}{ }^{2} \mathrm{H}_{2}\right]$-tyrosine, $0.1 \mu \mathrm{mol} \cdot \mathrm{kg}^{-1} \cdot \mathrm{min}^{-1} \quad \mathrm{~L}-\left[1{ }^{13} \mathrm{C}\right]$-leucine: Cambridge Isotopes Laboratories, Andover, USA). Participants rested in a supine position for $2.5 \mathrm{~h}$ until 23:30 h ( $\mathrm{t}=0 \mathrm{~min}$ ), after which the first muscle biopsy was taken. Subsequently, subjects ingested the beverage PLA, PRO, or PRO+leu within $5 \mathrm{~min}$ and went to sleep afterwards at $~ 00: 00 \mathrm{~h}$. During the night, blood samples $(10 \mathrm{~mL})$ were taken without waking up the subjects at $\mathrm{t}=30,60,90,150,210,330$, and 450 min relative to the intake of the protein drink. A second muscle biopsy was obtained from the contralateral leg 7.5 $\mathrm{h}$ later at $07: 00 \mathrm{~h}$ ( $\mathrm{t}=450 \mathrm{~min}$ ).

Blood samples were collected in tubes containing EDTA and centrifuged at $1000 \mathrm{~g}$ for $10 \mathrm{~min}$ at $4^{\circ} \mathrm{C}$. Aliquots of plasma were frozen in liquid nitrogen and stored at $-80^{\circ} \mathrm{C}$. Muscle biopsies were obtained from the middle region of the $M$. vastus lateralis, $15 \mathrm{~cm}$ above the patella and approximately $4 \mathrm{~cm}$ below entry through the fascia, using the percutaneous needle biopsy technique [25]. Muscle samples were dissected carefully and freed from any visible non-muscle material. The muscle samples were immediately frozen in liquid nitrogen and stored at $-80^{\circ} \mathrm{C}$ until further analysis. 


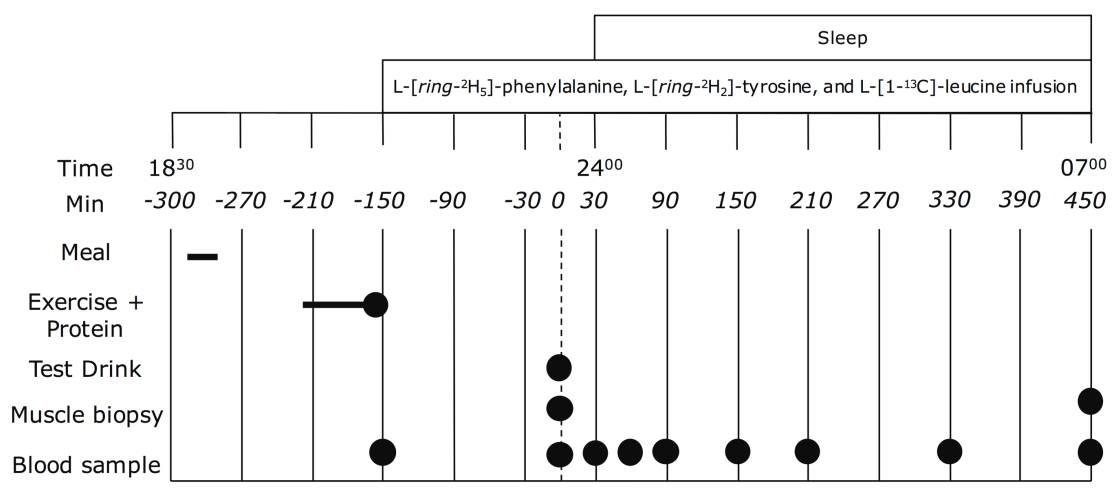

Figure 7.1. Experimental protocol. A drink with $20 \mathrm{~g}$ milk protein isolate and $45 \mathrm{~g}$ carbohydrate was ingested at 20:45 $\mathrm{h}$ immediately after cessation of exercise. Subjects were randomly assigned to ingest either $30 \mathrm{~g}$ intrinsically labeled casein protein, $30 \mathrm{~g}$ intrinsically labeled casein protein with an additional $2 \mathrm{~g}$ of crystalline leucine, or placebo (water) at 23:30 $\mathrm{h}$.

\section{Exercise protocol}

The exercise protocol consisted of 60 min of lower-body resistance-type exercise. After 15 min of selfpaced cycling at $150 \mathrm{~W}$ with a cadence of $60-80 \mathrm{rpm}$, subjects performed 6 sets of 10 repetitions on the horizontal leg press machine (Technogym BV, Rotterdam, the Netherlands) and 6 sets of 10 repetitions on the leg extension machine (Technogym BV, Rotterdam, the Netherlands). The first two sets of both exercises were performed at $55 \%$ and $65 \%$ of the subjects' 1 RM, respectively. Sets 3-6 were performed at $75 \%$ of $1 \mathrm{RM}$ and there were 2 -min rest intervals between all sets. Immediately after the exercise session, all subjects received drinks providing $20 \mathrm{~g}$ protein and $45 \mathrm{~g}$ carbohydrate (Gatorade G-series 03 Recover protein recovery shake, the Gatorade Company, Chicago, USA).

\section{Production of intrinsically labeled protein}

Intrinsically L-[1-13 C]-phenylalanine and L-[1-13 C]-leucine labeled casein protein was obtained during the constant infusion of L-[1- $\left.{ }^{13} \mathrm{C}\right]$-phenylalanine $\left(455 \mu \mathrm{mol} \cdot \mathrm{min}^{-1}\right)$ and L-[1- $\left.{ }^{13} \mathrm{C}\right]-$ leucine $\left(200 \mu \mathrm{mol} \cdot \mathrm{min}^{-1}\right)$ maintained for $96 \mathrm{~h}$ in a lactating dairy cow. The milk was collected, processed, and fractionated into the casein protein concentrate as previously described $[18,19,26]$. The $\mathrm{L}-\left[1-{ }^{13} \mathrm{C}\right]$-phenylalanine and L$\left[1-{ }^{13} \mathrm{C}\right]$-leucine enrichments in casein protein were measured by gas chromatography-combustionisotope ratio mass spectrometry (GC-IMRS; MAT 252, Finnigan, Breman, Germany) and averaged 38.7 molar percent excess (MPE) and 9.3 MPE, respectively. The proteins met all chemical and bacteriological specifications for human consumption. Each subject was randomized to participate in one experiment, in which water (PLA) with $30 \mathrm{~g}$ (PRO and PRO+leu) of intrinsically L- $\left[1-{ }^{13} \mathrm{C}\right]-$ phenylalanine and L- $\left[1-{ }^{13} \mathrm{C}\right]$-leucine labeled casein protein added up to an equal volume of $450 \mathrm{~mL}$ was ingested prior to sleep. In the PRO+leu treatments, an additional $2 \mathrm{~g}$ crystalline leucine was added. All test beverages were flavored by adding1.5 mL vanilla flavor (Dr. Oetker, Amersfoort, the Netherlands).

\section{Tracer preparation}

The stable isotope tracers $\mathrm{L}-\left[\right.$ ring- $\left.{ }^{2} \mathrm{H}_{5}\right]$-phenylalanine, $\mathrm{L}-\left[1-{ }^{13} \mathrm{C}\right]$-leucine and $\mathrm{L}-\left[\right.$ ring- $\left.-{ }^{2} \mathrm{H}_{2}\right]$-tyrosine were purchased from Cambridge Isotopes (Andover, USA) and dissolved in $0.9 \%$ saline before infusion (Basic Pharma, Geleen, the Netherlands). Continuous intravenous infusions were performed using a calibrated IVAC 598 pump (San Diego, CA, USA). 


\section{Plasma and muscle analysis}

Plasma glucose and insulin concentrations were analyzed using commercially available kits (GLUC3, Roche, Ref: 05168791 190, and Immunologic, Roche, Ref: 12017547 122, respectively). Plasma amino acid concentrations and enrichments were determined by gas chromatography-mass spectrometry analysis (GC-MS; Agilent 7890A GC/5975C; MSD, Wilmington, Delware, USA). Myofibrillar proteinbound L-ring-[2H5]-phenylalanine enrichments were determined by gas chromatography-combustion isotope ratio mass spectrometry analysis (Trace GC Ultra, IRMS model MAT 253; Thermo Scientific). Complete details on have been described previously ([27].

Western blot analyses were performed as described previously [28]. In short, $30 \mathrm{mg}$ of muscle tissue was homogenized and protein quantification performed. After protein quantification, the gels were transferred onto a nitrocellulose membrane. Total protein staining of the membrane (via Ponceau-S staining) was used as the normalization control (whole lane) for all blots. Specific proteins were detected by overnight incubation with the following antibodies: anti-mTOR (289 kDA, dilution 1:1,000, no 2972; Cell Signaling Technology, Danvers, MA), and anti-phospho mTOR (Ser ${ }^{2248}, 289 \mathrm{kDa}$, dilution 1:1,000, no. 2971; Cell Signaling Technology), anti-P70S6K (70 kDA, dilution 1:1,000), no 9202; Cell Signaling Technology) and anti-phospho P70S6K (Thr ${ }^{389}, 70$ kDA, dilution 1:1,000, no. 9206; Cell Signaling Technology), amti-rS6 (32 kDa, dilution 1:1,000, no. 2217; Cell Signaling Technology) and antiphospho-rS6 (Ser ${ }^{235} / \mathrm{Ser}^{236}, 32 \mathrm{kDa}$, dilution 1:1,000, no4856; Cell Signaling Technology). The complimentary secondary antibodies applied were IRDye 680 donkey anti-rabbit (cat. No. 926-32223, dilution 1:10,000; LI-COR Biotechnology, Lincoln, NE) and IRDye 800CW donkey anti-mouse (cat. No 926-32212, dilution 1:10,000; LI-COR Biotechnology). Protein quantification was performed by scanning on an Odyssey Infrared Imaging System (LI-COR Biotechnology).

\section{Calculations}

Ingestion of $\mathrm{L}-\left[1-{ }^{13} \mathrm{C}\right]$-phenylalanine labeled protein, intravenous infusion of $\mathrm{L}-\left[\right.$ ring- $\left.{ }^{2} \mathrm{H}_{5}\right]$-phenylalanine and L-[ring- ${ }^{2} \mathrm{H}_{2}$ ]-tyrosine, and blood sample enrichment values were used to assess whole-body amino acid kinetics in non-steady state conditions. Total, exogenous, and endogenous phenylalanine rate of appearance $\left(R_{a}\right)$ and plasma availability of dietary protein-derived phenylalanine that appeared in the

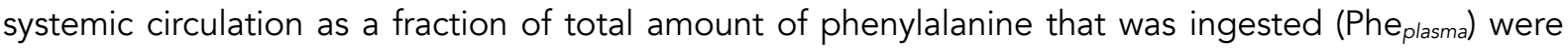
calculated using modified Steele's equations $[29,30]$. Total rate of disappearance of phenylalanine equals the rate of phenylalanine hydroxylation (first step in phenylalanine oxidation) and utilization for protein synthesis. Myofibrillar protein fractional synthetic rate (FSR) was calculated with the standard precursor-product method. The complete details have been described previously [27].

\section{Sleep quality assessment}

The Pittsburg Sleep Quality Index (PSOI, Sleep Medicine Institute, University of Pittsburgh) was used to assess habitual sleep quality during pretesting [31]. PSOl scoring (global scores 0-21 points; higher scores indicate worse sleep quality) was used to classify all subjects to very good, good, poor or very poor sleepers. Subjects that scored $>5$ (poor sleepers) were not included in the trial. Prior to sleep, and in the morning after the intervention, tiredness ratings were assessed using a visual analogue scale. Sleep behavior during the test night was monitored using wrist activity monitors (Philips Respironics, Murrysville, USA). Additionally, the start and end time of sleep were recorded throughout the trial. The following parameters were derived from sleep records and activity monitors: sleep time (clock time), wake time (clock time), sleep onset latency (the period of time between bed time and sleep start), sleep 
duration (h), time awake/light sleep (h), sleep efficiency (\%, sleep duration expressed as a percentage of time in bed), and wake bouts.

\section{Statistics}

All data are expressed as means \pm SEM. A sample size of 12 subjects per group including a $10 \%$ dropout rate was calculated with a power of $80 \%$ and a $\alpha$-level of 0.05 to detect a $20 \%$ difference in FSR between groups. Baseline characteristics between groups were compared using one-way ANOVA. Timedependent variables (i.e. plasma metabolite concentrations, plasma enrichments, whole-body protein kinetics, and signaling proteins) were analyzed by two-factor repeated measures ANOVA with time as within-subjects factor and treatment group as between-subjects factor. The analysis was carried out for the period starting at the time of protein administration, i.e., between $\mathrm{t}=0$ and $450 \mathrm{~min}$. Non timedependent variables (i.e. FSR values) were compared between treatment groups using one-way ANOVA. In case of significant interaction between time and treatment group, one-way ANOVA was performed to compare between treatments at different time points. In case of significant main effects of treatment, a Bonferroni post-hoc test was applied to locate group differences. Statistical significance was set at $P<0.05$. All calculations were performed using SPSS (version 21.0, IBM Corp., Armonk, NY, USA). 


\section{RESULTS}

\section{Plasma analysis}

Plasma glucose and insulin concentrations are shown in Figure 7.2. Both plasma glucose and plasma insulin concentrations were slightly higher in the PRO+leu group compared to the PLA and PRO groups throughout the overnight period (main effect treatment: $P<0.05$ ). Plasma glucose concentrations at $\mathrm{t}=$ 0 min averaged $5.5 \pm 0.1,5.2 \pm 0.1$, and $5.9 \pm 0.1 \mathrm{mmol} \cdot \mathrm{L}^{-1}$ in PLA, PRO, and PRO+leu, respectively, and showed an overall decline throughout the overnight period. Plasma insulin concentration at $\mathrm{t}=0 \mathrm{~min}$ averaged $7.8 \pm 1.8,5.4 \pm 0.7,9.5 \pm 2.7 \mathrm{mU} \cdot \mathrm{L}^{-1}$ in $\mathrm{PLA}, \mathrm{PRO}$, and $\mathrm{PRO}+\mathrm{leu}$, respectively, and showed a transient increase at $\mathrm{t}=30 \mathrm{~min}$ when casein protein was provided prior to sleep.

Plasma phenylalanine, tyrosine, and leucine concentrations are shown in Figure 7.3. Plasma amino acid concentrations $\left(\mu \mathrm{mol} \cdot \mathrm{L}^{-1}\right)$ were not different between treatments at baseline, but increased following casein protein ingestion prior to sleep (PRO and PRO+leu treatments, time $x$ treatment interaction: $P<0.001)$, and remained elevated throughout the overnight period when compared with PLA. In addition, plasma leucine concentrations were significantly higher from $t=30$ until $t=210$ min after ingestion in PRO+leu compared with PRO (Figure 7.3C).
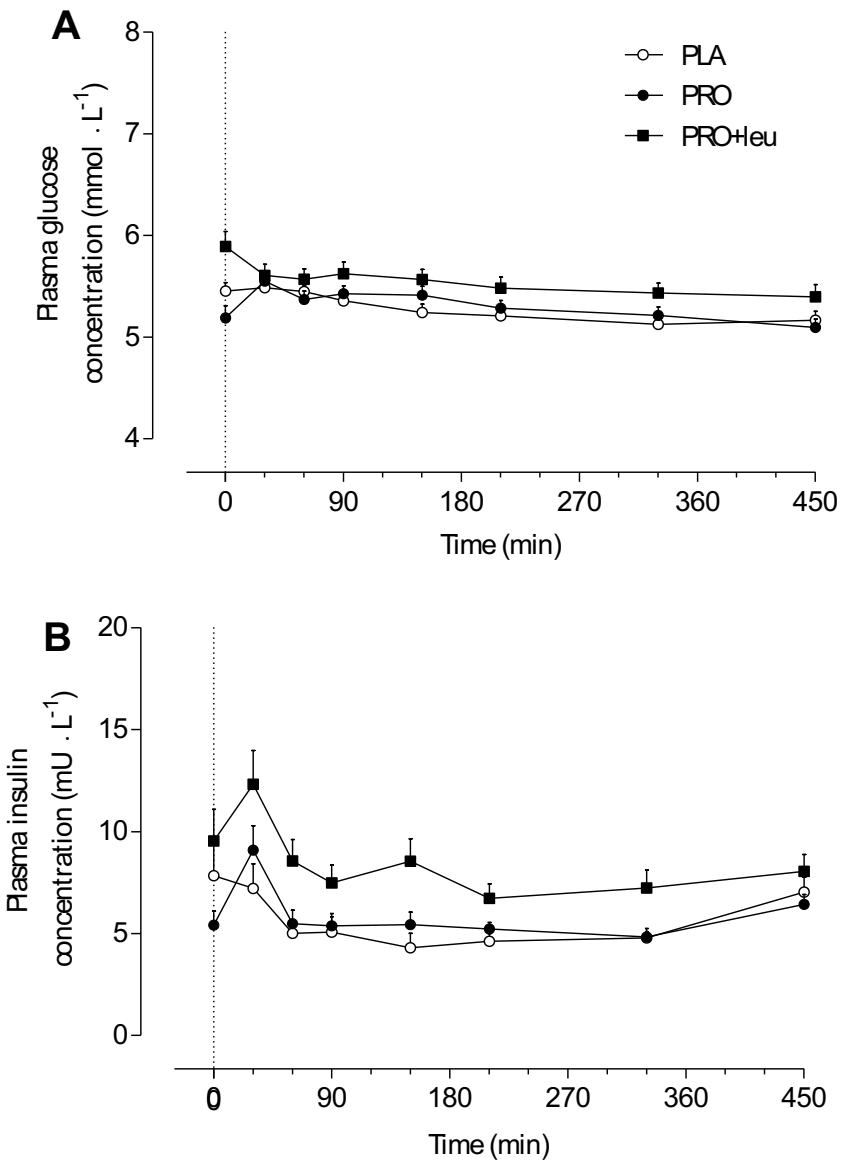

Figure 7.2. Overnight plasma glucose $\left(A, m m o l \cdot L^{-1}\right)$ and insulin concentration $\left(B, m U \cdot L^{-1}\right)$. The dotted line represents the ingestion of the casein protein or placebo drinks. Values represent means \pm SEM. Data were analyzed with a two-way repeated-measures (time $x$ treatment) ANOVA. Glucose: time effect: $P<0.001$; treatment effect: $P=0.037$; time $x$ treatment interaction: $P=0.004$. Insulin: time effect: $P<0.001$; treatment effect: $P=0.008$; time $\times$ treatment interaction: $P=0.148$. PLA: placebo, $P R O: 30 \mathrm{~g}$ casein protein, $\mathrm{PRO}+\mathrm{leu}: 30 \mathrm{~g}$ casein protein plus $2 \mathrm{~g}$ crystalline leucine. 

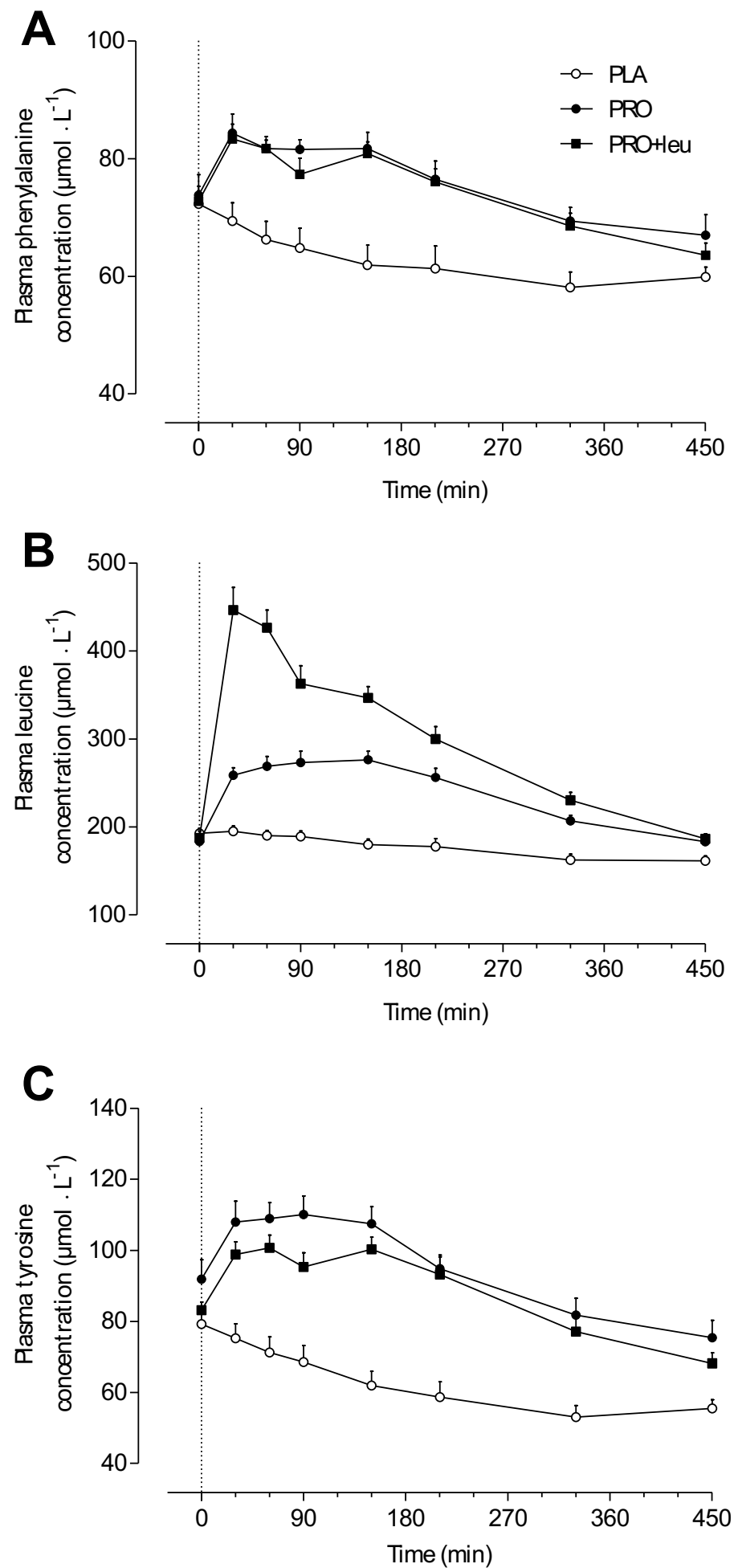

Figure 7.3. Overnight plasma phenylalanine (A), leucine (B) and tyrosine $(C)$ concentrations $\left(\mu \mathrm{mol} \cdot \mathrm{L}^{-1}\right)$. The dotted line represents the ingestion of the casein protein or placebo drink. Values represent means \pm SEM. Data were analyzed with a two-way repeatedmeasures (time $x$ treatment) ANOVA. Phenylalanine: time effect: $P<0.001$; treatment effect: $P=0.001$; time $\times$ treatment interaction: $P<0.001$. Leucine: time effect: $P<0.001$; treatment effect: $P<0.001$; time $\times$ treatment interaction: $P<0.001$. Tyrosine: time effect: $P<0.001$; treatment effect: $P<0.001$; time $x$ treatment interaction: $P<0.001$. PLA: placebo, PRO: $30 \mathrm{~g}$ casein protein, PRO+leu: $30 \mathrm{~g}$ casein protein plus $2 \mathrm{~g}$ crystalline leucine. 
Figure 7.4 shows the plasma L-[ring- $\left.{ }^{2} \mathrm{H}_{5}\right]$-phenylalanine, L-[1- $\left.{ }^{13} \mathrm{C}\right]$-leucine, and L- $\left[1-{ }^{13} \mathrm{C}\right]$-phenylalanine enrichments (MPE). Plasma tracer enrichments did not differ between treatments before ingesting the casein protein $(\mathrm{t}=\mathrm{O} \mathrm{min})$. Plasma $\mathrm{L}-\left[\mathrm{ring}_{-}{ }^{2} \mathrm{H}_{5}\right]$-phenylalanine increased slightly over time, and this increase was somewhat lower following casein protein ingestion (time $\mathrm{x}$ treatment interaction: $P<0.001)$. L- $\left[1-{ }^{13} \mathrm{C}\right]$-leucine increased slightly over time, and this increase was somewhat higher following casein protein ingestion (time $x$ treatment interaction: $P<0.001$ ). Plasma $L-\left[1-{ }^{13} \mathrm{C}\right]-$ phenylalanine concentrations, originating from the ingested casein protein, increased in the PRO and $\mathrm{PRO}+$ leu treatments, but not in the PLA treatment (Figure 7.4C; time $x$ treatment interaction: $P<0.001$ ).
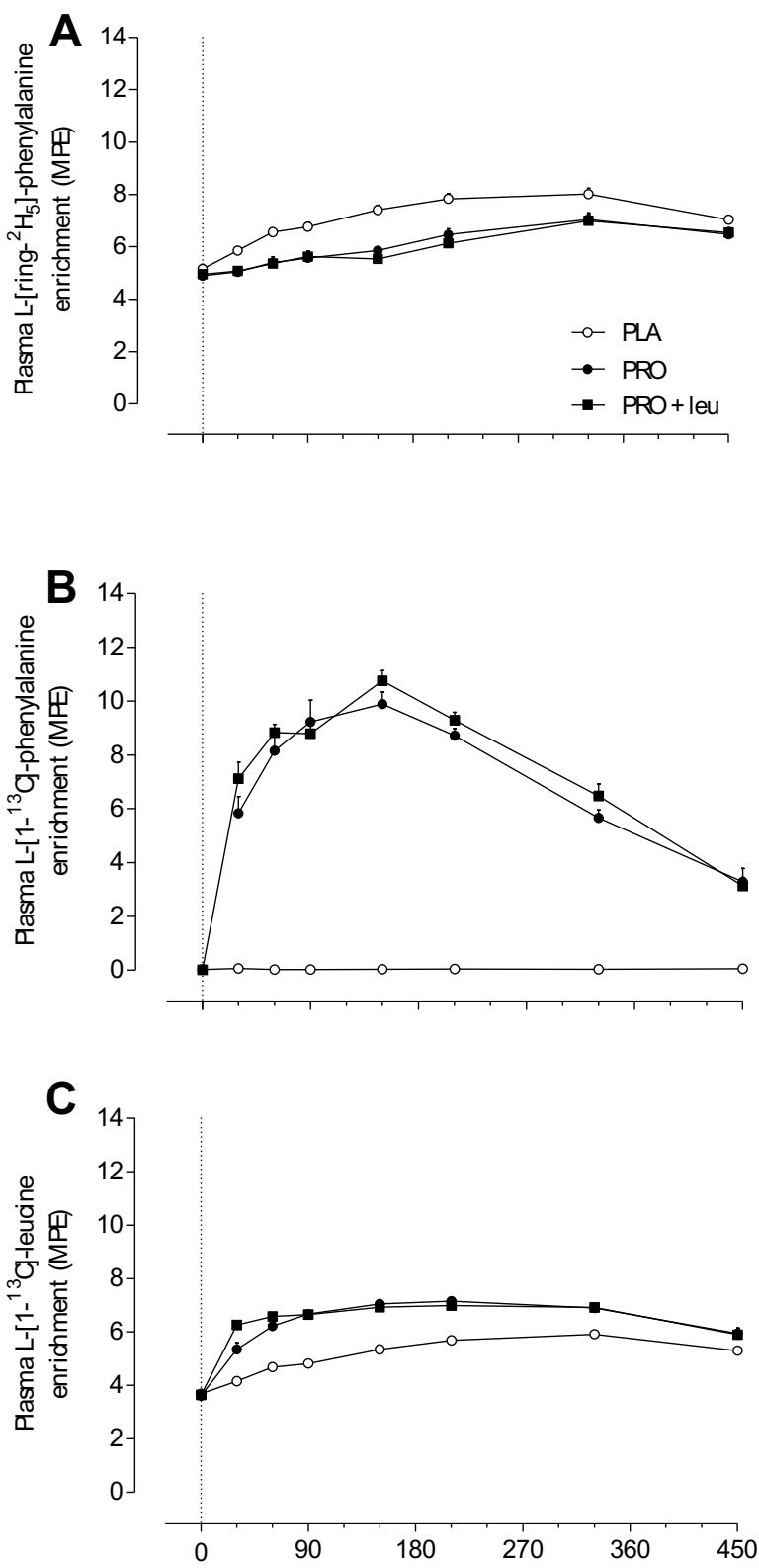

Figure 7.4. Overnight plasma L-[ring- $\left.{ }^{2} \mathrm{H}_{5}\right]$-phenylalanine (A), L-[1- $\left.-{ }^{13} \mathrm{C}\right]$-phenylalanine (B), L-[1- $\left.{ }^{13} \mathrm{C}\right]$-leucine (C) enrichments in mole percent excess (MPE). The dotted line represents the ingestion of the casein protein or placebo drinks. Values represent means \pm SEM. Data were analyzed with a two-way repeated-measures (time $x$ treatment) ANOVA. L-[ring- ${ }^{2} \mathrm{H}_{5}$ ]-phenylalanine enrichment: time effect: $P<0.001$; treatment effect: $P<0.001$; time $x$ treatment interaction: $P<0.001 . L-\left[1-{ }^{13} C\right]-$ phenylalanine enrichment: time effect: $P<0.001$; treatment effect: $P<0.001$; time $x$ treatment interaction: $P<0.001$. L-[1 $\left.-{ }^{13} \mathrm{C}\right]-l e u c i n e$ enrichment: time effect: $P<0.001$; treatment effect: $P<0.001$; time $\times$ treatment interaction: $P<0.001$. PLA: placebo, PRO: $30 \mathrm{~g}$ casein protein, $\mathrm{PRO}+\mathrm{leu}: 30 \mathrm{~g}$ casein protein plus $2 \mathrm{~g}$ crystalline leucine. 
Whole-body phenylalanine kinetics are presented in Figure 7.5. Exogenous phenylalanine rates of appearance increased following casein protein ingestion in PRO and PRO+leu, but did not change in PLA (Figure 7.5A). Endogenous phenylalanine rates of appearance decreased following the ingestion of the experimental test drinks, but did not differ between treatments (Figure 7.5B). As a result, total phenylalanine rates of appearance were higher in PRO and PRO+leu compared with PLA (Figure 7.5C). Likewise, total phenylalanine rates of disappearance were increased following casein protein ingestion (Figure 7.5D). The amount of dietary protein-derived phenylalanine that appeared in the circulation over the $7.5 \mathrm{~h}$ overnight period was $56 \pm 2 \%$ and $60 \pm 2 \%$ in PRO and PRO+leu, respectively, with no differences between treatments $(P=0.099)$.
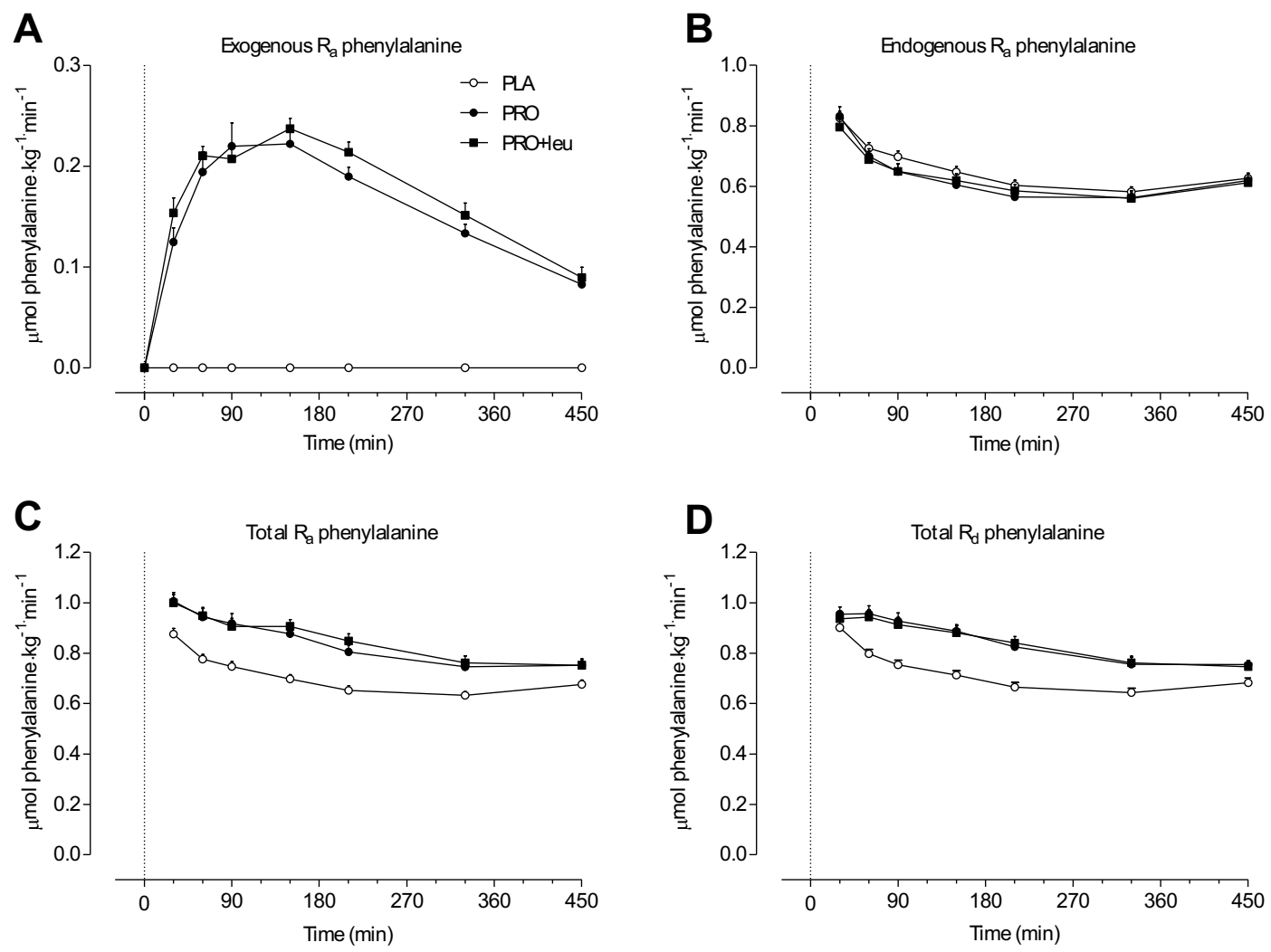

Figure 7.5. Overnight exogenous phenylalanine rate of appearance $\left(R_{a}\right)(A)$, endogenous phenylalanine $R_{a}(B)$, total phenylalanine $R_{a}(C)$, and total phenylalanine rate of disappearance $\left(R_{d}\right)(D)$. The dotted line represents the ingestion of the casein protein or placebo drinks. Values represent means \pm SEM. Data were analyzed with a two-way repeated-measures (time $x$ treatment) ANOVA. Exogenous phenylalanine $R_{a}$ : time effect: $P<0.001$; treatment effect: $P<0.001$; time $x$ treatment interaction: $P<0.001$. Endogenous phenylalanine $R_{a}$ : time effect: $P<0.001$; treatment effect: $P=0.479$; time $x$ treatment interaction: $P=0.512$. Total phenylalanine $R_{\mathrm{a}}$ : time effect: $P<0.001$; treatment effect: $P<0.001$; time $x$ treatment interaction: $P=0.008$. Total phenylalanine $R_{d}$ : time effect: $P<0.001$; treatment effect: $P<0.001$; time $x$ treatment interaction: $P=0.001$. PLA: placebo, PRO: $30 \mathrm{~g}$ casein protein, PRO+leu: $30 \mathrm{~g}$ casein protein plus $2 \mathrm{~g}$ crystalline leucine.

Data on whole-body protein metabolism are expressed in Figure 7.6. Whole-body protein synthesis and oxidation rates were higher in PRO and PRO+leu compared with PLA $(P<0.05)$, while breakdown rates did not differ between treatments. As a result, whole-body protein net balance was higher following casein protein ingestion (PRO: $53 \pm 2, \mathrm{PRO}+\mathrm{leu}: 59 \pm 3$, and PLA: $-6 \pm 1 \mu \mathrm{mol}$ phenylalanine $\cdot \mathrm{kg}^{-}$ $\left.1.7 .5 h^{-1}, P<0.001\right)$. 


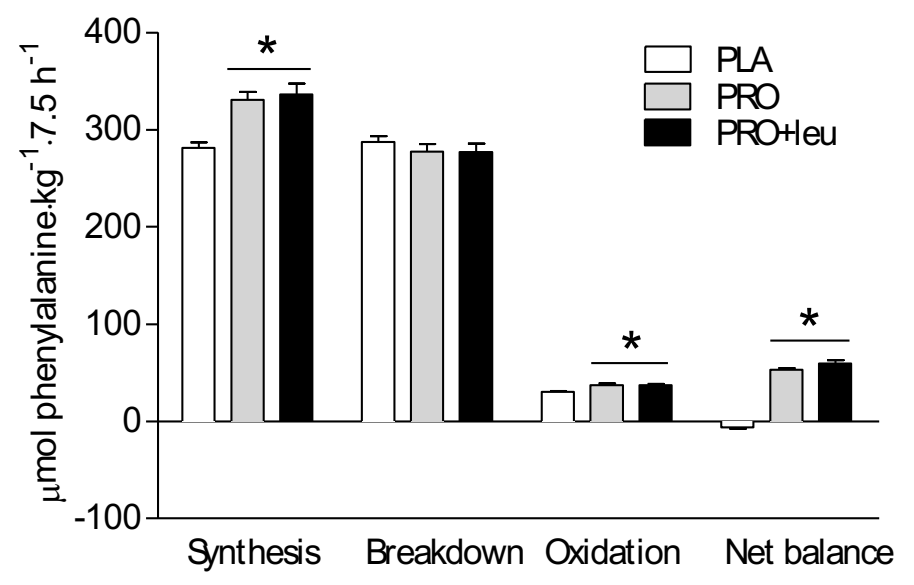

Figure 7.6. Calculated rates of overnight whole-body protein synthesis, breakdown, oxidation (using phenylalanine hydroxylation to tyrosine as a proxy for phenylalanine oxidation), and net balance ( $\mu \mathrm{mol}$ phenylalanine $\cdot \mathrm{kg}^{-1} \cdot 7.5 \mathrm{~h}^{-1}$ ). Values represent means \pm SEM. Data were analyzed with one-way ANOVA and Bonferroni post-hoc test was used to locate differences between treatments. Synthesis: main treatment effect: $P<0.001$, post-hoc: ${ }^{\star} P R O$ and $P R O+l e u$ different compared to PLA, $P<0.01$. Breakdown: main treatment effect: $P=0.553$. Oxidation: main treatment effect: $P=0.005$, post hoc: ${ }^{*} P R O$ and $P R O+l e u$ different compared to PLA, $P<0.05$. Net-balance: main treatment effect: $P<0.001$, post-hoc: ${ }^{*} P R O$ and $P R O+l e u$ different compared to PLA, $P<0.001$. PLA: placebo, PRO: $30 \mathrm{~g}$ casein protein, $P R O+l e u: 30 \mathrm{~g}$ casein protein plus $2 \mathrm{~g}$ crystalline leucine.

\section{Myofibrillar fractional synthesis rates and protein-bound enrichments}

Myofibrillar protein fractional synthetic rates (FSR) based upon L-[ring- $\left.{ }^{2} \mathrm{H}_{5}\right]$-phenylalanine infusion with plasma $\mathrm{L}-\left[\right.$ ring $\left.-{ }^{2} \mathrm{H}_{5}\right]$ enrichments as precursor $(\mathrm{A})$ or using $\mathrm{L}-\left[1-{ }^{13} \mathrm{C}\right]$-leucine ingestion and infusion with plasma $\mathrm{L}-\left[1-{ }^{13} \mathrm{C}\right]$-leucine enrichments as precursor $(\mathrm{B})$ are displayed in Figure 7.7. Myofibrillar protein FSR as calculated over the $7.5 \mathrm{~h}$ overnight period did not differ between treatments based on the L[ring- ${ }^{2} \mathrm{H}_{5}$ ]-phenylalanine tracer $\left(0.057 \pm 0.002,0.055 \pm 0.002\right.$, and $0.055 \pm 0.004 \% \cdot h^{-1}$ for PLA, PRO, and $\mathrm{PRO}+$ leu, respectively; $\mathrm{P}=0.850$ ). In agreement, myofibrillar muscle protein FSR did not differ between treatments based on the $\mathrm{L}-\left[1-{ }^{13} \mathrm{C}\right]$-leucine tracer $\left(0.080 \pm 0.004,0.073 \pm 0.004\right.$, and $0.083 \pm 0.006 \% \cdot \mathrm{h}^{-1}$ for PLA, PRO, and PRO+leu, respectively; $P=0.328)$. Myofibrillar $L-\left[1-{ }^{13} \mathrm{C}\right]$-phenylalanine enrichments were higher following protein ingestion compared to PLA $(P<0.001)$, reaching values of $0.026 \pm 0.003$ and $0.031 \pm 003 \mathrm{MPE}$ in the PRO and PRO+leu treatments, respectively (Figure 7.8).
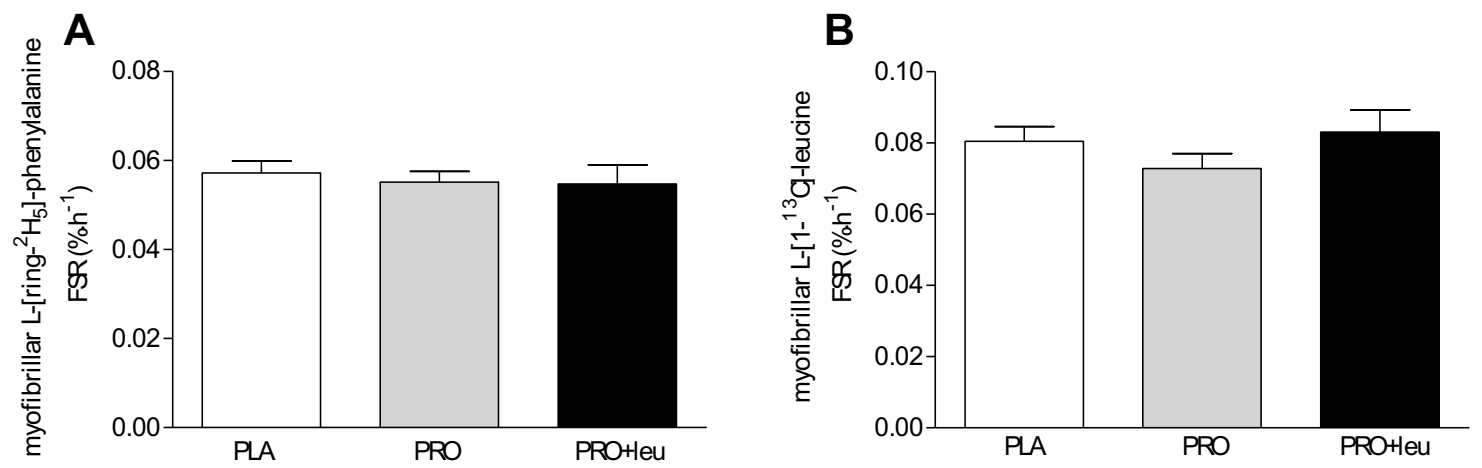

Figure 7.7. Overnight myofibrillar protein fractional synthetic rates ( $F S R$ in $\% \mathrm{~h}^{-1}$ ) as calculated using $\mathrm{L}-\left[\mathrm{ring}_{-}{ }^{2} \mathrm{H}_{5}\right.$-phenylalanine $(A)$, or $\mathrm{L}-\left[1-{ }^{13} \mathrm{C}\right]$-leucine $(\mathrm{B})$ as tracer. Values represent means \pm SEM. Data were analyzed with one-way ANOVA. No significant differences between treatments ( $P>0.05$ ). PLA: placebo, PRO: $30 \mathrm{~g}$ casein protein, PRO+leu: $30 \mathrm{~g}$ casein protein plus $2 \mathrm{~g}$ crystalline leucine. 


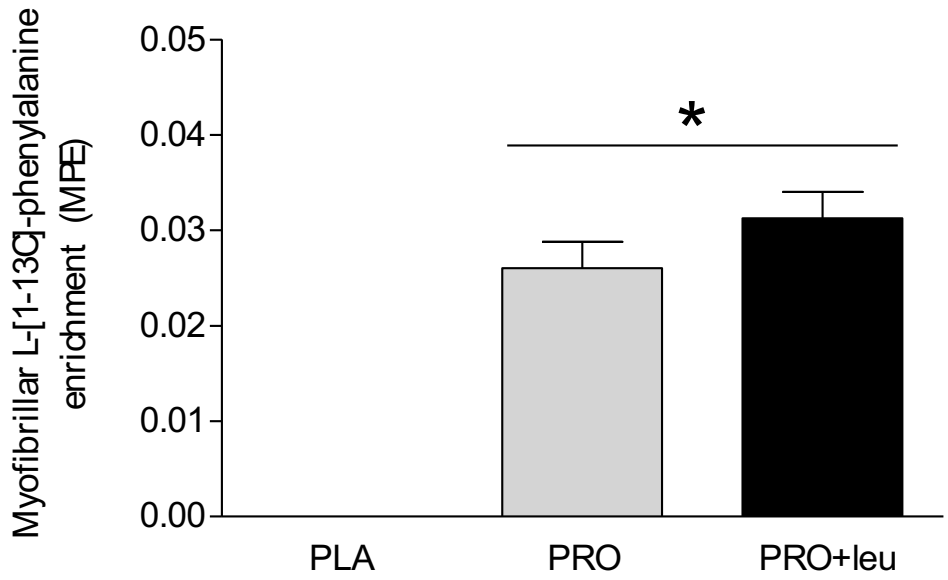

Figure 7.8. Overnight L-[1- $\left.{ }^{13} \mathrm{C}\right]$-phenylalanine incorporation in myofibrillar protein (mole percent excess, MPE). Values represent means \pm SEM. Data were analyzed with one-way ANOVA and Bonferroni post-hoc test was used to locate differences between treatments. Main treatment effect: $P<0.001$, post-hoc: ${ }^{*} P R O$ and PRO+leu different compared to PLA, $P<0.001$. PLA: placebo, PRO: $30 \mathrm{~g}$ casein protein, PRO+leu: $30 \mathrm{~g}$ casein protein plus $2 \mathrm{~g}$ crystalline leucine.

\section{Signaling proteins}

The muscle phosphorylation status of selected proteins involved in the regulation of muscle protein synthesis are displayed in Figure 7.9. Data are expressed as the rations between the phosphorylated proteins and the total protein content. Directly before pre-sleep drink ingestion ( $t=0 \mathrm{~min}$ ), a higher phosphorylation status was observed for P70S6K and rS6 when compared to the next morning after $7.5 \mathrm{~h}$ of overnight sleep $(P<0.01$ and $P<0.001$, respectively). Changes over time did not differ between treatments (time $x$ treatment interaction, $P>0.05$ ).
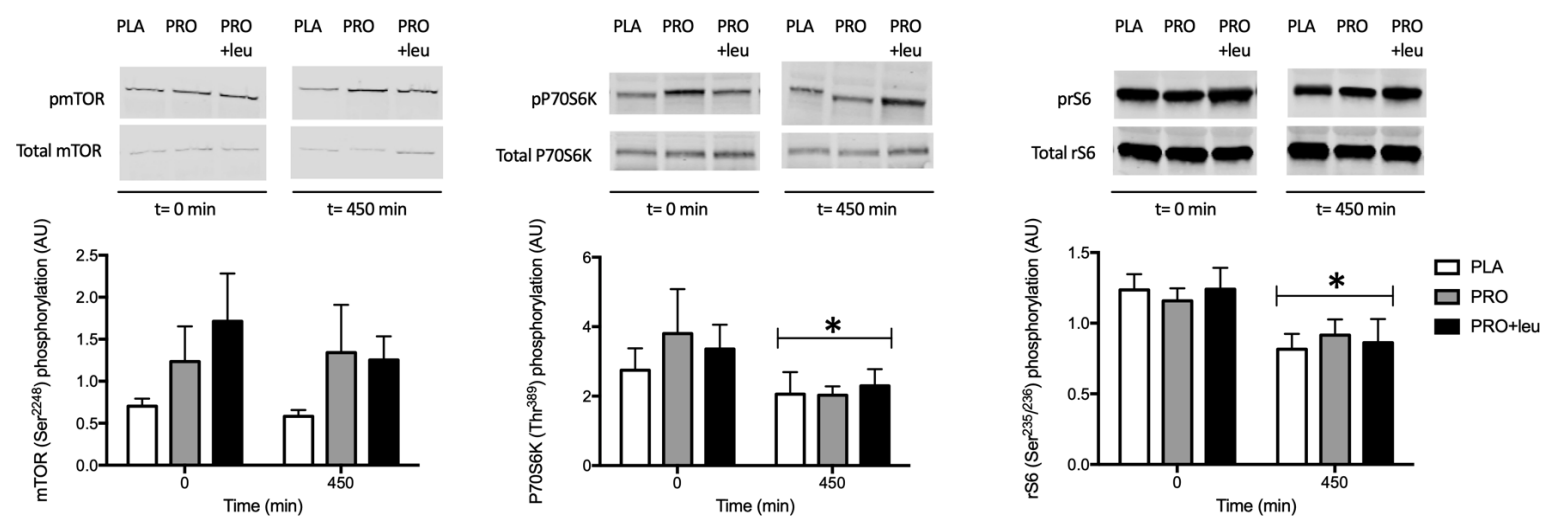

Figure 7.9. Skeletal muscle phosphorylation status of selected proteins. Muscle samples were taken directly before pre-sleep drink ingestion ( $\mathrm{t}=0 \mathrm{~min}$ ) and after $7.5 \mathrm{~h}$ of overnight sleep ( $\mathrm{t}=450 \mathrm{~min}$ ). $\mathrm{mTOR}$ : time effect: $P=0.403$, treatment effect: $P=0.467$, time $\times$ treatment interaction: $P=0.467$. P70S6K: time effect: $P<0.01$, treatment effect: $P=0.839$, time $\times$ treatment interaction: $P=0.516$. rS6: time effect: $P<0.001$, treatment effect: $P=0.989$; time $\times$ treatment interaction: $P=0.250$. *Significant time effect $(P<0.05)$. 


\section{Sleep Data}

There were no differences in VAS tiredness scores between treatments prior to sleep, or in the morning. Sleep analysis data are presented in Table 7.2. Total sleep duration did not differ between the treatments (PLA: 5:56 $\pm 0: 08, P R O: 6: 00 \pm 0: 11, P R O+l e u: 6: 06 \pm 0: 06$ (hh:mm), $P=0.770$ ). In addition, there were no significant differences in sleep time, wake time, sleep onset latency (the period of time between bedtime and sleep start), or sleep efficiency (\% sleep duration expressed as a percentage of time in bed) between the treatments.

Table 7.2. Sleep analysis data

\begin{tabular}{|c|c|c|c|c|c|c|c|c|c|c|}
\hline \multirow[b]{2}{*}{ Sleep time (hh:mm) } & \multicolumn{3}{|c|}{$\begin{array}{c}\text { PLA } \\
(n=11)\end{array}$} & \multicolumn{3}{|c|}{$\begin{array}{l}\text { PRO } \\
(n=12)\end{array}$} & \multicolumn{3}{|c|}{$\begin{array}{c}\text { PRO+leu } \\
(n=11) \\
\end{array}$} & \multirow{2}{*}{$\begin{array}{c}P \\
0.849\end{array}$} \\
\hline & $00: 02$ & \pm & $0: 05$ & $23: 57$ & \pm & $0: 06$ & $23: 59$ & \pm & $0: 03$ & \\
\hline Wake time (hh:mm) & $6: 52$ & \pm & 0.08 & $6: 53$ & \pm & $0: 07$ & $6: 51$ & \pm & 0:04 & 0.951 \\
\hline Sleep onset latency (hh:mm) & 0:09 & \pm & 0:02 & $0: 11$ & \pm & 0.02 & $0: 12$ & \pm & 0:04 & 0.830 \\
\hline Sleep duration (hh:mm) & $5: 56$ & \pm & 0:08 & $6: 00$ & \pm & $0: 11$ & $6: 06$ & \pm & 0:06 & 0.770 \\
\hline Time awake/Light sleep (hh:mm) & $0: 26$ & \pm & 0:05 & $0: 30$ & \pm & $0: 08$ & $0: 24$ & \pm & 0:03 & 0.789 \\
\hline Sleep efficiency $(\%)$ & 87 & \pm & 3 & 87 & \pm & 3 & 89 & \pm & 2 & 0.772 \\
\hline Wake Bouts & 12 & \pm & 2 & 11 & \pm & 2 & 11 & \pm & 2 & 0.911 \\
\hline
\end{tabular}

Values are expressed as means \pm SEM. Data were analyzed with one-way ANOVA.

\section{Hunger and satiety in the morning}

The VAS hunger and satiety scores prior to casein protein ingestion or following the overnight period before (ad libitum) breakfast did not differ between treatments. Energy intake at breakfast averaged 3.1 $\pm 0.1 \mathrm{MJ}(14 \pm 1 \mathrm{En} \%$ protein, $53 \pm 2 \mathrm{En} \%$ carbohydrate, and $30 \pm 2 \mathrm{En} \%$ fat) during the ad libitum breakfast with no differences between treatments $(P=0.986)$. 


\section{DISCUSSION}

The present study demonstrates that protein ingested prior to sleep is rapidly digested with $~ 55 \%$ of the ingested protein-derived amino acids appearing in the systemic circulation throughout overnight sleep. These protein-derived amino acids improve whole-body protein balance and are taken up and incorporated into myofibrillar protein. However, the ingestion of $30 \mathrm{~g}$ casein protein with or without an additional $2 \mathrm{~g}$ leucine did not increase muscle protein synthesis rates during a $7.5 \mathrm{~h}$ post-exercise overnight period.

In the present study we combined the ingestion of specifically produced intrinsically $\mathrm{L}-\left[1-{ }^{13} \mathrm{C}\right]-$ phenylalanine labeled protein with continuous infusion of L-[ring- $\left.{ }^{2} \mathrm{H}_{5}\right]$-phenylalanine to assess the rate of dietary protein-derived amino acids being released in the circulation and their impact on wholebody protein kinetics during overnight sleep. Exogenous dietary protein-derived phenylalanine appearance rates remained elevated throughout overnight sleep (Figure 7.5A), with $\sim 55 \%$ of the ingested protein-derived amino acids being released in the circulation over the entire $7.5 \mathrm{~h}$ overnight period. These data are in line with previous observations showing $50 \%$ of ingested casein protein becoming available in the systemic circulation during a $5-7 \mathrm{~h}$ postprandial period $[16,32,33]$.

We have previously shown that ingestion of $40 \mathrm{~g}$ casein protein prior to sleep increases whole-body protein synthesis rates, resulting in a positive protein net balance during overnight sleep [16]. In the current study, we observed that ingestion of a more moderate dose of $30 \mathrm{~g}$ casein protein also improves whole-body protein synthesis rates and allows for a more positive overnight whole-body protein net balance (Figure 7.6). As whole-body protein kinetics do not necessarily reflect skeletal muscle metabolism, we also collected skeletal muscle biopsies before and after overnight sleep to assess the overnight muscle protein synthetic response to pre-sleep casein protein feeding.

In contrast to our hypothesis, the ingestion of $30 \mathrm{~g}$ casein protein did not significantly increase myofibrillar protein synthesis rates when assessed over a $7.5 \mathrm{~h}$ overnight period (Figure 7.7). It could be speculated that the absence of increased myofibrillar protein synthesis rates following pre-sleep protein is due to the prior protein feedings. The muscle full effect proposes that protein ingestion stimulates muscle protein synthesis for 1-3 hours, after which muscle protein synthesis rates rapidly return to baseline levels even when plasma amino acid concentrations remain elevated [34,35]. However, we have previously shown that the ingestion $40 \mathrm{~g}$ casein protein prior to sleep increases overnight mixed muscle protein synthesis rates under near identical conditions [16]. It is possible that such a proposed refractory period is less evident in a setting of post-exercise recovery [36,37]. An alternative explanation could be the measurement of myofibrillar as opposed to mixed muscle [16] protein synthesis rates. However, the protein dose-response relationship appears to be similar for mixed-muscle and myofibrillar protein synthesis rates [7,24], and $30 \mathrm{~g}$ of casein protein should be more than sufficient to stimulate myofibrillar protein synthesis rates in younger males [24]. Therefore, the most likely explanation for the absence of a significant increase in overnight myofibrillar protein synthesis rate following the ingestion of $30 \mathrm{~g}$ protein prior to sleep is the more moderate amount of protein ingested. This implies that more than $30 \mathrm{~g}$ casein protein may be required to significantly increase myofibrillar protein synthesis rates during a $7.5 \mathrm{~h}$ post-exercise overnight period. 
In addition to the applied continuous intravenous infusions of L-[ring $\left.-{ }^{2} \mathrm{H}_{5}\right]$-phenylalanine and L- $\left[1-{ }^{13} \mathrm{C}\right]-$ leucine to measure myofibrillar protein synthesis rates, the ingestion of highly enriched intrinsically L$\left[1-{ }^{13} \mathrm{C}\right]$-phenylalanine labeled protein allowed us to also assess the metabolic fate of the pre-sleep dietary protein-derived amino acids. Muscle protein bound $\mathrm{L}-\left[1-{ }^{13} \mathrm{C}\right]$-phenylalanine enrichments increased following protein ingestion (Figure 7.8), demonstrating that the casein protein ingested prior to sleep provided amino acids which are incorporated into myofibrillar protein during overnight sleep. As we did not observe a concomitant increase in myofibrillar protein synthesis rates assessed over the entire $7.5 \mathrm{~h}$ overnight period, we can only speculate that an early post-prandial rise in pre-sleep proteinderived amino acid incorporation into muscle protein does not suffice to elevate overnight muscle protein synthesis rates when expressed over the entire $7.5 \mathrm{~h}$ overnight recovery period. In support, we have previously shown that daily ingestion of $\sim 30 \mathrm{~g}$ protein prior to sleep augments the gains in muscle mass and strength during 3 months of prolonged resistance-type exercise training in young males [38]. Previous work from our group [11] as well as others [12,39], has shown that increasing the leucine content in a dose of protein/amino acids can further augment the postprandial muscle protein synthetic response to protein feeding and increase the efficacy by which dietary protein-derived amino acids are used for incorporation into muscle protein. Despite the greater plasma leucine availability following leucine co-ingestion, we observed no significant increase in overnight muscle protein synthesis rates (Figure 7.7). Likewise, we failed to observe greater protein-derived phenylalanine incorporation rates into skeletal myofibrillar protein following leucine co-ingestion (Figure 7.8). The absence of such a stimulating effect following leucine co-ingestion could be attributed to the relative long period over which the muscle protein synthetic response was assessed. Leucine co-ingestion produces a rapid but transient increase in muscle protein synthesis [12], which may not have been detectable when assessed over an extended $7.5 \mathrm{~h}$ period. While the leucine content of a meal is an important determinant of postprandial muscle protein synthesis rates [40], other essential amino acids are also capable of stimulating muscle protein synthesis $[37,41]$. Our previous and current work combined suggest that the total pre-sleep protein/essential amino acid content is a more important determinant of overnight muscle protein synthesis than merely the leucine content.

The postprandial stimulation of muscle protein synthesis is initiated by a phosphorylation cascade in which mammalian target of rapamycin (mTOR) and its downstream effectors P70S6 kinase (P70S6K) and ribosomal protein S6. (RS6) are key players [42]. Here we show that following a day of standardized nutrition and a single bout of resistance-type exercise performed in the evening, the phosphorylation status of P70S6K and RS6 is higher immediately prior to sleep ( $t=0 \mathrm{~min}$ ) when compared to the overnight fasted state the following morning ( $t=450 \mathrm{~min}$, Figure 7.9). The ingestion of $30 \mathrm{~g}$ casein protein with or without additional free leucine prior to sleep did not lead to additional changes in the activation of mTOR, P70S6K, or RS6 the following morning ( $t=450 \mathrm{~min}$ ) when compared to the placebo treatment. This is not surprising considering previous work showing the peak of this translation initiation process to occur 1-2 $\mathrm{h}$ following protein ingestion after which it subsides $[37,43,44]$. Of course, the timing of our muscle biopsy collection was chosen to allow 7.5 hours of uninterrupted sleep and was therefore not designed to detect temporary changes in either anabolic signaling or muscle protein synthesis during the early as opposed to the late post-prandial phase. Leucine plays an important role in the activation of the mTOR pathway and muscle protein synthesis $[45,46]$. It could be speculated that the absence of increased myofibrillar protein synthesis rates following leucine co-ingestion is due to the anabolic signaling already being fully activated during the early stages of the overnight period. 
The present study shows that ingestion of $30 \mathrm{~g}$ casein protein with or without additional free leucine prior to sleep is not sufficient to stimulate overnight muscle protein synthesis during post-exercise overnight recovery. However, we do show that casein protein ingested prior to sleep provides amino acids that are incorporated into myofibrillar protein and improves overnight whole-body protein net balance during sleep. The increase in whole-body protein synthesis following pre-sleep protein ingestion may reflect an increase in protein synthesis in tissues other than muscle, i.e. splanchnic tissues. In support, feeding has been shown to improve gut tissue protein net balance [47]. However, it is not clear if a more positive protein net balance in splanchnic tissues results in organ growth and whether this has any functional relevance. Furthermore, it should be noted that on a whole-body level the rate of amino acids disappearing from the circulation (i.e. tissue uptake) minus amino acid oxidation rates are assumed to reflect whole-body protein synthesis rates. This is not necessarily true, as amino acids may be temporarily stored in tissue free amino acid pools without actual incorporation into tissue protein (i.e. true protein synthesis), and be released back into the circulation at a later stage. In contrast, the use of skeletal muscle biopsies allowed us to assess the actual incorporation of dietary proteinderived amino acids into myofibrillar protein and determine myofibrillar protein synthesis rates. The observed pre-sleep protein-derived amino acid incorporation appears to translate into a measurable benefit when applied during a more prolonged period of resistance-type exercise training. Specifically, we have previously demonstrated that the ingestion of $\sim 30 \mathrm{~g}$ casein protein prior to sleep augments muscle mass and strength gains during 3 months of resistance-type exercise training in healthy young males [38].

In contrast to the present study, we have previously shown that the ingestion of a larger amount of casein protein prior to sleep (i.e., $40 \mathrm{~g}$ ) increases overnight muscle protein synthesis rates [16]. These data suggest that a pre-sleep protein dose-response relationship exists, which differs from the immediate post-exercise recovery period during which $20 \mathrm{~g}$ seems sufficient to maximize muscle protein synthesis rates $[7,8]$. Future work should identify a maximal stimulatory protein dose for overnight muscle protein synthesis and aim to find strategies that allow smaller amounts of protein to be more effective. Such work may provide interesting opportunities for the design of feeding strategies that optimize overnight muscle reconditioning in healthy or more clinically compromised populations. In conclusion, casein protein ingestion prior to sleep provides amino acids that are incorporated in myofibrillar protein during sleep. However, the ingestion of $30 \mathrm{~g}$ casein protein with or without additional free leucine prior to sleep is does not increase myofibrillar protein synthesis rates during overnight post-exercise sleep.

\section{ACKNOWLEDGEMENTS}

We acknowledge the enthusiastic support of the subjects who volunteered to participate in these experiments.

\section{DISCLOSURES}

The project is funded by TI Food and Nutrition, a public-private partnership on precompetitive research in food and nutrition. The researchers are responsible for the study design, data collection and analysis, decision to publish, and preparation of the manuscript. The industrial partners have contributed to the project through regular discussion. Ian Rollo is an employee of the Gatorade Sports Science Institute, 
a division of PepsiCo Inc. The views expressed in this manuscript are those of the authors and do not necessarily reflect the position or policy of Pepsico Inc. The other authors report no conflict of interest.

\section{AUTHOR CONTRIBUTIONS}

J.T., I.R., L.B.V., and L.J.V.L. conception and design of research; J.T., I.W.K., A.M.H., and T.S. performed experiments; J.T. and S.L.H. analyzed data; J.T. and L.J.v.L. interpreted results of experiments; J.T. prepared figures; J.T. drafted manuscript, J.T., I.W.K., A.M.H., T.S., S.L.H., I.R., L.B.V., and L.J.v.L. edited and revised manuscript; J.T., I.W.K., A.M.H., T.S., S.L.H., I.R., L.B.V., and L.J.v.L .approved final version of manuscript. 


\section{REFERENCES}

1. Phillips SM, Tipton KD, Aarsland A, Wolf SE, Wolfe RR. Mixed muscle protein synthesis and breakdown after resistance exercise in humans. Am J Physiol. 1997;273:E99-107.

2. Biolo G, Maggi SP, Williams BD, Tipton KD, Wolfe RR. Increased rates of muscle protein turnover and amino acid transport after resistance exercise in humans. Am J Physiol. 1995;268:E514-20.

3. Tipton KD, Ferrando AA, Williams BD, Wolfe RR. Muscle protein metabolism in female swimmers after a combination of resistance and endurance exercise. J Appl Physiol (1985). 1996;81:20348.

4. Biolo G, Tipton KD, Klein S, Wolfe RR. An abundant supply of amino acids enhances the metabolic effect of exercise on muscle protein. Am J Physiol. 1997;273:E122-9.

5. Borsheim E, Tipton KD, Wolf SE, Wolfe RR. Essential amino acids and muscle protein recovery from resistance exercise. Am J Physiol Endocrinol Metab. 2002;283:E648-57.

6. Koopman R, Walrand S, Beelen M, Gijsen AP, Kies AK, Boirie Y, et al. Dietary protein digestion and absorption rates and the subsequent postprandial muscle protein synthetic response do not differ between young and elderly men. J Nutr. 2009;139:1707-13.

7. Moore DR, Robinson MJ, Fry JL, Tang JE, Glover El, Wilkinson SB, et al. Ingested protein dose response of muscle and albumin protein synthesis after resistance exercise in young men. Am J Clin Nutr. 2009;89:161-8.

8. Witard OC, Jackman SR, Breen L, Smith K, Selby A, Tipton KD. XMyofibrillar muscle protein synthesis rates subsequent to a meal in response to increasing doses of whey protein at rest and after resistance exercise. Am J Clin Nutr. 2014;99:86-95.

9. Tang JE, Moore DR, Kujbida GW, Tarnopolsky MA, Phillips SM. Ingestion of whey hydrolysate, casein, or soy protein isolate: effects on mixed muscle protein synthesis at rest and following resistance exercise in young men. J Appl Physiol (1985). 2009;107:987-92.

10. Wilkinson SB, Tarnopolsky MA, Macdonald MJ, Macdonald JR, Armstrong D, Phillips SM. Consumption of fluid skim milk promotes greater muscle protein accretion after resistance exercise than does consumption of an isonitrogenous and isoenergetic soy-protein beverage. Am J Clin Nutr. 2007;85:1031-40.

11. Wall BT, Hamer HM, de Lange A, Kiskini A, Groen BBL, Senden JMG, et al. Leucine co-ingestion improves post-prandial muscle protein accretion in elderly men. Clin Nutr. 2013;32:412-9.

12. Churchward-Venne TA, Breen L, Di Donato DM, Hector AJ, Mitchell CJ, Moore DR, et al. Leucine supplementation of a low-protein mixed macronutrient beverage enhances myofibrillar protein synthesis in young men: a double-blind, randomized trial. Am J Clin Nutr. 2014;99:276-86.

13. Areta JL, Burke LM, Ross ML, Camera DM, West DWD, Broad EM, et al. Timing and distribution of protein ingestion during prolonged recovery from resistance exercise alters myofibrillar protein synthesis. J Physiol. 2013;591:2319-31.

14. Levenhagen DK, Gresham JD, Carlson MG, Maron DJ, Borel MJ, Flakoll PJ. Postexercise nutrient intake timing in humans is critical to recovery of leg glucose and protein homeostasis. Am J Physiol Endocrinol Metab. 2001;280:E982-93.

15. Beelen M, Tieland M, Gijsen AP, Vandereyt $H$, Kies AK, Kuipers $H$, et al. Coingestion of carbohydrate and protein hydrolysate stimulates muscle protein synthesis during exercise in young men, with no further increase during subsequent overnight recovery. J Nutr. 2008;138:2198-204. 
16. Res PT, Groen B, Pennings B, Beelen M, Wallis GA, Gijsen AP, et al. Protein ingestion before sleep improves postexercise overnight recovery. Medicine \& Science in Sports \& Exercise. 2012;44:1560-9.

17. Gillen JB, Trommelen J, Wardenaar FC, Brinkmans NYJ, Versteegen JJ, Jonvik KL, et al. Dietary Protein Intake and Distribution Patterns of Well-Trained Dutch Athletes. Int J Sport Nutr Exerc Metab. 2016;:1-23.

18. van Loon LJC, Boirie Y, Gijsen AP, Fauquant J, de Roos AL, Kies AK, et al. The production of intrinsically labeled milk protein provides a functional tool for human nutrition research. J Dairy Sci. 2009;92:4812-22.

19. Pennings B, Pellikaan WF, Senden JMG, van Vuuren AM, Sikkema J, van Loon LJC. The production of intrinsically labeled milk and meat protein is feasible and provides functional tools for human nutrition research. J Dairy Sci. 2011;94:4366-73.

20. Burd NA, Cermak NM, Kouw IWK, Gorissen SH, Gijsen AP, van Loon LJC. The use of doubly labeled milk protein to measure postprandial muscle protein synthesis rates in vivo in humans. $J$ Appl Physiol (1985). 2014;117:1363-70.

21. Jones PR, Pearson J. Anthropometric determination of leg fat and muscle plus bone volumes in young male and female adults. J Physiol. 1969;204:63P-66P.

22. Mayhew JL, Prinster JL, Ware JS, Zimmer DL, Arabas JR, Bemben MG. Muscular endurance repetitions to predict bench press strength in men of different training levels. J Sports Med Phys Fitness. 1995;35:108-13.

23. Raben A, Tagliabue A, Astrup A. The reproducibility of subjective appetite scores. Br J Nutr. 1995;73:517-30.

24. Witard OC, Jackman SR, Breen L, Smith K, Selby A, Tipton KD. Myofibrillar muscle protein synthesis rates subsequent to a meal in response to increasing doses of whey protein at rest and after resistance exercise. Am J Clin Nutr. 2013;99:86-95.

25. Bergstrom J. Percutaneous needle biopsy of skeletal muscle in physiological and clinical research. Scand. J. Clin. Lab. Invest. 1975;35:609-16.

26. Burd NA, Hamer HM, Pennings B, Pellikaan WF, Senden JMG, Gijsen AP, et al. Substantial Differences between Organ and Muscle Specific Tracer Incorporation Rates in a Lactating Dairy Cow. PLoS One. 2013;8:e68109.

27. Trommelen J, Holwerda AM, Kouw IWK, Langer H, Halson SL, Rollo I, et al. Resistance Exercise Augments Postprandial Overnight Muscle Protein Synthesis Rates. Medicine \& Science in Sports \& Exercise. 2016;48:2517-25.

28. Dirks ML, Hansen D, Van Assche A, Dendale P, van Loon LJC. Neuromuscular electrical stimulation prevents muscle wasting in critically ill comatose patients. Clin Sci (Lond). 2015;128:357-65.

29. Dangin M, Guillet C, Garcia-Rodenas C, Gachon P, Bouteloup-Demange C, Reiffers-Magnani K, et al. The rate of protein digestion affects protein gain differently during aging in humans. $J$ Physiol. 2003;549:635-44.

30. Boirie Y, Gachon P, Corny S, Fauquant J, Maubois JL, Beaufrere B. Acute postprandial changes in leucine metabolism as assessed with an intrinsically labeled milk protein. Am J Physiol. 1996;271:E1083-91.

31. Buysse DJ, Reynolds CF3, Monk TH, Berman SR, Kupfer DJ. The Pittsburgh Sleep Quality Index: a new instrument for psychiatric practice and research. Psychiatry Res. 1989;28:193-213. 
32. Gorissen SHM, Burd NA, Kramer IF, van Kranenburg J, Gijsen AP, Rooyackers O, et al. Coingesting milk fat with micellar casein does not affect postprandial protein handling in healthy older men. Clin Nutr. 2015.

33. Groen BBL, Horstman AM, Hamer HM, de Haan M, van Kranenburg J, Bierau J, et al. PostPrandial Protein Handling: You Are What You Just Ate. Thompson D, editor. PLoS One. 2015;10:e0141582-22.

34. Bohe J, Low JF, Wolfe RR, Rennie MJ. Latency and duration of stimulation of human muscle protein synthesis during continuous infusion of amino acids. J Physiol. 2001;532:575-9.

35. Atherton PJ, Etheridge T, Watt PW, Wilkinson D, Selby A, Rankin D, et al. Muscle full effect after oral protein: time-dependent concordance and discordance between human muscle protein synthesis and mTORC1 signaling. Am J Clin Nutr. 2010;92:1080-8.

36. Moore DR, Tang JE, Burd NA, Rerecich T, Tarnopolsky MA, Phillips SM. Differential stimulation of myofibrillar and sarcoplasmic protein synthesis with protein ingestion at rest and after resistance exercise. J Physiol. 2009;587:897-904.

37. Churchward-Venne TA, Burd NA, Mitchell CJ, West DWD, Philp A, Marcotte GR, et al. Supplementation of a suboptimal protein dose with leucine or essential amino acids: effects on myofibrillar protein synthesis at rest and following resistance exercise in men. J Physiol. 2012;590:2751-65.

38. Snijders T, Res PT, Smeets JSJ, van Vliet S, van Kranenburg J, Maase K, et al. Protein Ingestion before Sleep Increases Muscle Mass and Strength Gains during Prolonged Resistance-Type Exercise Training in Healthy Young Men. J Nutr. American Society for Nutrition; 2015;145:117884.

39. Pasiakos SM, McClung HL, McClung JP, Margolis LM, Andersen NE, Cloutier GJ, et al. Leucineenriched essential amino acid supplementation during moderate steady state exercise enhances postexercise muscle protein synthesis. Am J Clin Nutr. 2011;94:809-18.

40. Norton LE, Wilson GJ, Layman DK, Moulton CJ, Garlick PJ. Leucine content of dietary proteins is a determinant of postprandial skeletal muscle protein synthesis in adult rats. Nutrition \& Metabolism. 2012;9:67.

41. Smith K, Reynolds N, Downie S, Patel A, Rennie MJ. Effects of flooding amino acids on incorporation of labeled amino acids into human muscle protein. Am J Physiol. 1998;275:E738.

42. Watson K, Baar K. mTOR and the health benefits of exercise. Semin Cell Dev Biol. 2014;36:1309.

43. Drummond MJ, Dickinson JM, Fry CS, Walker DK, Gundermann DM, Reidy PT, et al. Bed rest impairs skeletal muscle amino acid transporter expression, mTORC1 signaling, and protein synthesis in response to essential amino acids in older adults. Am J Physiol Endocrinol Metab. 2012;302:E1113-22.

44. Glover El, Phillips SM, Oates BR, Tang JE, Tarnopolsky MA, Selby A, et al. Immobilization induces anabolic resistance in human myofibrillar protein synthesis with low and high dose amino acid infusion. J Physiol. 2008;586:6049-61.

45. Kimball SR, Jefferson LS. New functions for amino acids: effects on gene transcription and translation. Am J Clin Nutr. 2006;83:500S-507S.

46. Moberg M, Apro W, Ohlsson I, Ponten M, Villanueva A, Ekblom B, et al. Absence of leucine in an essential amino acid supplement reduces activation of mTORC1 signalling following resistance exercise in young females. Appl. Physiol. Nutr. Metab. 2014;39:183-94. 
47. Deutz NE, Have Ten GA, Soeters PB, Moughan PJ. Increased intestinal amino-acid retention from the addition of carbohydrates to a meal. Clin Nutr. 1995;14:354-64. 



\section{Chapter 8}

General discussion 


\section{GENERAL DISCUSSION}

While initial research in sports nutrition has mainly focused on carbohydrate intake as an ergogenic aid, more recently the focus has shifted towards the impact of nutrition on the skeletal muscle adaptive response to exercise training. In this thesis, we investigated the impact of carbohydrate and/or protein ingestion to improve exercise performance, recovery, and/or the skeletal muscle adaptive response to exercise training. In this final chapter, we will address the implications of the presented findings, and discuss them in a broader perspective. At the end of this chapter, we will define goals for future research in this area.

\section{Role of carbohydrate in sports nutrition}

It is now well-established that carbohydrate is the main substrate source during prolonged moderateto high-intensity exercise $[1,2]$. In early work by Levine et al., low plasma glucose concentrations were observed in participants following the completion of the Boston Marathon of 1924 [3]. This was especially the case in participants who had more difficulty finishing the race. Based on this observation, it was speculated that low plasma glucose concentrations may cause fatigue. They tested their hypothesis by providing carbohydrates to participants during the following edition of the Boston Marathon [4]. In line with their hypothesis, carbohydrate supplementation prevented hypoglycemia and improved running performance. Subsequently, much work has since been performed investigating the impact of carbohydrate intake during exercise on substrate utilization and exercise performance [2].

Exogenous carbohydrate oxidation rates are restricted to $\sim 1 \mathrm{~g} \cdot \mathrm{min}^{-1}$ even when greater amounts of glucose or glucose polymers are ingested $[5,6]$. The rate of exogenous glucose oxidation appears to be limited by the capacity for intestinal glucose absorption $[5,6]$. Fructose is absorbed by an intestinal transport route that is distinct from glucose $[7,8]$. Therefore, the combined ingestion of glucose plus fructose may result in higher total intestinal carbohydrate absorption and subsequent exogenous carbohydrate oxidation rates. In support, several studies have shown that fructose co-ingestion with glucose results in higher exogenous carbohydrate oxidation rates $\left(1.2-1.8 \mathrm{~g} \cdot \mathrm{min}^{-1}\right)$ when compared to an isocaloric amount of glucose $[9,10]$. We confirm these findings in chapter 2 , and extend on these by demonstrating that sucrose co-ingestion results in similar exogenous carbohydrate oxidation rates when compared to the combined ingestion of glucose and fructose when total carbohydrate content is matched. These data suggest that sucrose may represent an effective carbohydrate source to provide multiple transportable carbohydrates during exercise.

The ergogenic properties of carbohydrate ingestion during prolonged ( $\geq 2 \mathrm{~h}$ ), endurance-type exercise have been well established [11,12]. However, carbohydrate ingestion has also been shown to improve performance during high-intensity exercise of a relative short duration ( $\leq 60 \mathrm{~min}$ ), despite that endogenous carbohydrate stores should not be a limiting factor for performance during exercise of such a short duration $[13,14]$. This ergogenic effect is now generally attributed to carbohydrate sensing in the oral cavity, as carbohydrate mouth rinsing has been shown to improve exercise capacity and performance during exercise lasting $\sim 60 \mathrm{~min}[15,16]$. In chapter 3 , we assessed the impact of sucrose mouth rinsing on cycling time trial performance in the fasted and fed state. Sucrose mouth rinsing did not improve time-trial performance in either the fasted or the fed state. Therefore, it remains to be determined whether carbohydrate mouth rinsing is truly ergogenic, and if so, under which conditions $[17,18]$. 
Carbohydrate availability during exercise is determined by exogenous carbohydrate intake as well as endogenous storage in muscle and the liver. In the 1960's, the introduction of muscle biopsies allowed for the assessment of muscle glycogen levels $[19,20]$. Bergstrom et al. observed that muscle glycogen levels are strongly related to endurance-type exercise capacity and can be manipulated through carbohydrate intake in the diet [20]. Subsequently, much research has been performed on carbohydrate loading strategies to optimize muscle glycogen concentrations prior to exercise [21]. Following exhaustive endurance-type exercise, depleted muscle glycogen stores can be fully repleted within 24 h when sufficient carbohydrates are ingested [22]. However, athletes do not always have such a prolonged recovery period available (e.g. during multi-day events like the Tour de France). Therefore, research typically focusses on maximizing muscle glycogen repletion rates during the first couple of hours following exercise (i.e. 2-6 h). It has been well established that carbohydrate intake augments post-exercise muscle glycogen repletion rates [23]. Protein co-ingestion with carbohydrate can further increase muscle glycogen repletion rates [24], but only when carbohydrate intake is suboptimal (i.e. $\leq 1.2 \mathrm{~g} / \mathrm{kg} / \mathrm{d}$ ) [25]. In the last two decades, attempts to further increase muscle glycogen repletion rates beyond levels achieved with an optimal glucose intake have been unsuccessful. In chapter 4, we assessed the impact of combining glucose and fructose ingestion on post-exercise muscle glycogen repletion rates. Because of distinct transport routes of glucose and fructose, we hypothesized that fructose co-ingestion would further increase total carbohydrate absorption and accelerate muscle glycogen repletion rates. While we did not observe an increase in muscle glycogen repletion rates, fructose co-ingestion resulted in less gastrointestinal distress when compared to the ingestion of an isocaloric amount of glucose. Therefore, fructose co-ingestion may facilitate the capacity to achieve optimal carbohydrate intake during recovery from exhaustive exercise.

\section{Role of protein in sports nutrition}

While muscle mass is remarkably constant in healthy adults, it is a highly adaptive organ capable of changing in size and/or function. Even when muscle mass is constant, muscle tissue is constantly turning over, i.e. the rates at which muscle proteins are synthesized and broken down are in balance. This tissue protein turnover allows muscle tissue to remodel, e.g. replacing damaged proteins with new proteins or changing the composition of muscle proteins to adapt to challenges such as exercise. An imbalance between protein synthesis and protein breakdown rates in skeletal muscle results in either a net gain (synthesis > breakdown) or net loss (breakdown > synthesis) in muscle mass. A single session of exercise stimulates muscle protein synthesis (MPS) rates, and to a lesser extent, muscle protein breakdown rates $[26,27]$. However, muscle protein net balance will remain negative in the absence of food intake [27]. Protein ingestion stimulates MPS and inhibits muscle protein breakdown rates, resulting in net muscle protein accretion during the acute stages of post-exercise recovery [28]. In chapter 6, we demonstrated that resistance-type exercise performed in the evening augments the overnight MPS response to presleep protein ingestion and allows more of the ingested protein-derived amino acids to be used for de novo MPS during overnight sleep. These findings further support the notion that the impact of protein ingestion to augment the adaptive response to exercise is not limited to the first few of hours recovery [29].

Various factors have been identified that can modulate the MPS response to feeding, including the amount $[30,31]$, type $[32,33]$, and timing [34] of protein ingestion. However, much of this work has 
focused on isolated amino acids or rapidly digestible protein isolates ingested in absence of other nutrients $[30-32,34]$. Such conditions may not be reflective of the postprandial MPS response to the ingestion of a mixed meal, in which protein is typically consumed in the form of more slowly digestible, whole-food protein sources [35]. Therefore, the remainder of this chapter will discuss the dietary factors that modulate the MPS response to feeding.

\section{Amount of protein}

Few studies have investigated the dose-response relationship between protein ingestion and MPS rates during recovery from resistance-type exercise in younger adults. Moore et al. was the first to present a dose response in MPS rates following the ingestion of $0,5,10,20$ or $40 \mathrm{~g}$ egg protein during recovery from lower-body exercise [30]. They observed a dose-dependent increase in MPS rates up to the ingestion of $20 \mathrm{~g}$ protein, with a nonsignificant $\sim 10 \%$ further increase following the ingestion of 40 g protein (Figure 8.1a). Witard et al. followed up on this work by assessing the impact of ingesting increasing amounts of whey protein on MPS rates at rest and during post-exercise recovery using a unilateral leg exercise model [31]. In that study, subjects ingested a standardized protein-rich breakfast $4 \mathrm{~h}$ prior to the ingestion of the protein beverages. The ingestion of $20 \mathrm{~g}$ whey protein was sufficient to maximize MPS rates at rest and during post-exercise recovery, with a non-significant $~ 10 \%$ further increase following the ingestion of $40 \mathrm{~g}$ protein in the post-exercise condition. More recently, the ingestion of $20 \mathrm{~g}$ and $40 \mathrm{~g}$ whey protein were compared in a cross-over design following whole-body resistance-type exercise [36]. The $40 \mathrm{~g}$ dose resulted in a significant $20 \%$ higher MPS rates compared to the $20 \mathrm{~g}$ dose. These data may suggest that the amount of protein required to maximize MPS rates following whole-body resistance-type exercise is higher when compared with exercise during which less muscle is recruited. However, this hypothesis requires confirmation in a more direct comparison. Taken together, it appears that the ingestion of $20 \mathrm{~g}$ isolated, fast digestible protein results in a nearmaximal MPS response at rest and during post-exercise recovery, with a $10-20 \%$ further increase in MPS rates when the ingested amount is doubled to $40 \mathrm{~g}$ (Figure 8.1a).

The impact of ingesting varying amounts of protein on post-exercise MPS rates in young adults has been limited to experimental settings investigating the impact of ingesting isolated, rapidly digestible protein sources on MPS rates during $4-5 \mathrm{~h}$ of post-exercise recovery $[30,31,36]$. These conditions are ecologically valid for the acute post-exercise period in which the ingestion of rapidly digestible protein supplements is common practice. However, such conditions are not reflective of most meal situations in which protein is generally consumed as a part of more slowly digestible, nutrient-rich, whole-food protein sources that are provided in a mixed meal. Therefore, it should be questioned whether these data can be directly translated to per-meal protein recommendations.

\section{Type of protein}

Plant-based protein sources are typically considered to be less efficient at stimulating MPS rates when compared to animal-based protein sources. The possible lower anabolic properties of plant-based protein sources may be attributed to the lower essential amino acid content, limited content of specific amino acids, lower leucine content, lower digestibility, and/or higher splanchnic extraction of plantbased protein derived amino acids [37]. Indeed, most studies show that the ingestion of animal-based protein sources generally results in higher MPS rates at rest or following resistance-type exercise when compared to plant-based protein sources in younger and older adults $[6,7,19]$. We have recently 
observed a significant increase in MPS in older adults following the ingestion of $60 \mathrm{~g}$ wheat protein hydrolysate, but not following the ingestion of $35 \mathrm{~g}$ wheat protein hydrolysate [38]. These data suggest that consumption of a greater amount of plant-based proteins may form an effective strategy to compensate for their lower quality. However, it remains to be determined whether the ingestion of large amounts of plant-based protein can maximize MPS rates in younger adults and/or following resistance-type exercise (Figure 8.1b). It is important to note that the impact of plant-based protein sources on MPS rates has been limited to the ingestion of protein isolates. A typical mixed meal is likely to also include some animal-based protein and/or contain different plant-based protein sources which may provide a more balanced amino acid profile [39]. Therefore, the proposed lower MPS response to the ingestion of a single plant-based protein source can potentially be rescued by the ingestion of blends of multiple (plant-based) protein sources (Figure 8.1b).

\section{Protein digestion and amino acid absorption rate}

Dietary protein sources can differ substantially in their protein digestion and amino acid absorption kinetics. For example, whey is a rapidly digestible protein that results in a rapid but transient postprandial increase in plasma amino acid concentrations [40]. In contrast, casein is a more slowly digestible protein that results in a more moderate, but sustained, post-prandial increase in plasma amino acid concentrations. The ingestion of whey protein typically stimulates MPS rates to a greater extent than casein protein when assessed over periods up to $6 \mathrm{~h}$ at rest or during the acute stages of post-exercise recovery $[32,40,41]$. This has been attributed to the more rapid protein digestion and amino acid absorption kinetics as well as the higher leucine content in whey compared to casein protein, resulting in a more rapid post-prandial rise in amino acid availability [40,42-44]. Furthermore, the post-exercise MPS response to whey protein ingestion is attenuated when ingested in multiple smaller doses over time versus bolus ingestion [45]. These data suggest that protein digestion and absorption kinetics, and timing of intake, modulate the MPS response even when amino acid composition is matched. Therefore, it can be questioned if the optimal amount of ingested protein as established for rapidly digestible protein sources can be translated to more slowly digestible protein sources.

The post-exercise MPS response to the ingestion of different amounts of slowly digestible proteins has not been assessed in healthy young men. This response may have a different temporal pattern compared to more rapidly digestible proteins. Ingestion of increasing amounts of a more slowly digestible protein may result in a moderate, but more sustained, MPS response consistent with its protein digestion and absorption pattern (Figure 8.1c). Some support for this concept comes from our work on pre-sleep protein feeding. In chapter 7, we observed that the ingestion of $30 \mathrm{~g}$ casein protein prior to sleep did not result in a detectable increase in post-exercise MPS assessed over a prolonged $7.5 \mathrm{~h}$ overnight period. In contrast, we previously observed a $22 \%$ increase in overnight MPS rates following the ingestion of $40 \mathrm{~g}$ casein protein under nearly identical conditions [46]. While it should be noted that these studies assessed post-exercise MPS rates in different muscle protein fractions (i.e. mixed-muscle vs myofibrillar protein), the ingestion of $30 \mathrm{~g}$ protein should be more than sufficient to stimulate post-exercise mixed-muscle or myofibrillar protein synthesis rates over a $4-5 \mathrm{~h}$ period $[30,31]$. Therefore, it appears that larger amounts of slowly digestible protein are required to obtain a more robust stimulation of post-exercise MPS rates when assessed over more prolonged periods such as overnight sleep [47]. This may suggest that the optimal amount and type of ingested protein depends 
on the meal timing, with $\sim 20 \mathrm{~g}$ of fast digestible protein being preferred when there is a relatively short 3-5 $\mathrm{h}$ period until the next meal, but ingestion of $\geq 40 \mathrm{~g}$ slower digestible protein may be favoured when there is a prolonged period until the next feeding opportunity. It appears that pre-sleep protein feeding is an overlooked opportunity to ingest protein for many athletes. In chapter 5, we assessed dietary protein intake and protein intake distribution pattern of well-trained Dutch athletes. We observed that total daily protein intake was generally in line with recommendations, but athletes ingest only $\sim 7 \mathrm{~g}$ protein as their evening snack.

\section{Macronutrients versus meals}

Most work assessing the MPS response to feeding has focused on the ingestion of an amount of protein isolate. However, dietary-protein is typically consumed as part of a mixed meal. The co-ingestion of foods that are not necessarily high in protein contribute to total protein intake, the amino acid profile of the meal, protein digestion and amino acid absorption kinetics, post-prandial hormonal response, and (micro)nutrient intake. Such factors can modulate the MPS response to feeding, but it is impossible to assess their individual contribution to the post-prandial muscle protein synthetic response [48].

Carbohydrate co-ingestion with protein delays protein absorption and amino acid digestion [49], although this does not seem to lower the MPS response to protein ingestion at rest or during recovery from resistance-type exercise $[49,50]$. However, studies assessing the impact of carbohydrate coingestion on the post-prandial muscle protein synthetic response to feeding are limited to the coingestion of rapidly digestible, high glycemic index carbohydrates. In contrast, mixed meals provide more slowly digestible carbohydrates and also contain dietary fibre. Therefore, a greater delay in protein digestion and amino acid absorption kinetics can be expected following ingestion of a mixed meal compared with the ingestion of a protein-carbohydrate supplement. In support, the postprandial rise in plasma amino acid levels appears to be substantially attenuated when minced meat is consumed in a mixed meal [51,52]. Furthermore, it has been suggested that carbohydrate co-ingestion may augment MPS rates by increasing post-prandial insulin release. However, the post-prandial rise in circulating insulin levels is permissive for MPS during hyperaminoacidemia and does not further stimulate MPS rates under conditions reflecting food ingestion at rest $[53,54]$. Consistent with this notion, carbohydrate co-ingestion with protein does not further augment MPS rates during recovery from resistance-type exercise.

Not much work has addressed the potential impact of fat co-ingestion on the MPS response to protein ingestion. Post-exercise amino acid uptake by the leg (indicative of muscle protein accretion), has been shown to be higher following the ingestion of high fat milk when compared with skim milk [55]. More recently, we observed no delay in protein digestion and amino acid absorption and the subsequent MPS rates when milk fat was co-ingested with a beverage containing casein protein in older adults at rest [56]. This absence of a delay in protein digestion and amino acid absorption kinetics may be attributed to layering of fat on top of protein in the stomach that may only occur with a liquid meal [57]. However, co-ingestion of $17 \mathrm{~g}$ fat as provided by the consumption of whole eggs did not attenuate post-exercise protein digestion and amino acid absorption kinetics when compared to the ingestion of an isonitrogenous amount of egg whites [58]. Therefore, fat co-ingestion does not appear to substantially impact protein digestion and amino acid absorption kinetics. However, there is some indication that that an oversupply of lipid may impair postprandial MPS. Lipid infusion reduces the MPS 
response to the ingestion of amino acids under hyperinsulinemic-euglycemic clamped conditions in healthy younger adults at rest [59]. In addition, attenuated post-exercise intramuscular anabolic signalling (i.e. 4E-BP1 phosphorylation) has been observed following the combined ingestion of protein and fat when compared to the combined ingestion of protein and carbohydrate [60]. Therefore, the impact of the fat content of a protein containing meal on the MPS response remains ambiguous.

Recent work suggests that the MPS response to feeding may be modulated by the consumption of other nutrients (Figure 8.1d). In support, the ingestion of whole-eggs has been shown to be more effective in stimulating post-exercise MPS rates when compared to the ingestion of an isonitrogenous amount of egg whites [58]. The differential response could not be attributed to differences in protein digestion and amino acid absorption or caloric intake between the treatments $[49,50,56]$. A possible explanation is the considerably higher fat content in whole eggs and/or the presence of other nutrients with anabolic properties. As previously discussed, fat co-ingestion may augment the post-exercise MPS response to protein ingestion [55]. Furthermore, several micronutrients that are present primarily in the yolk, such as vitamin $A$, vitamin $D$, vitamin $E$, zinc, selenium and cholesterol, are potential candidates that may be responsible for the greater anabolic response to feeding [48,61]. In addition, the coingestion of an amylopectin/chromium complex has recently been shown to augment the post-exercise MPS response to the ingestion of a suboptimal amount of protein [62]. However, it should be noted some nutrients may potentially impair MPS when ingested in large amounts in excess of what is typically consumed in the diet. For example, the ingestion of the lipid second messenger phosphatidic acid has recently been shown to impair the post-exercise MPS response in older adults [63]. Furthermore, highdose anti-oxidant supplementation (i.e. vitamin $\mathrm{C}$ and $\mathrm{E}$ ) may blunt the adaptive response to exercise [64]. Therefore, highly dosed micronutrient supplementation with strong anti-oxidant properties is not recommended for athletes. Taken together, emerging evidence suggests that certain (micro)nutrients in a meal may be able to modulate postprandial MPS rates. The MPS response to mixed meal ingestion may, therefore, differ from the ingestion of protein isolates due to changes in protein and amino acid absorption kinetics and/or the modulating effects of specific (micro)nutrient(s) content(s) (Figure 8.1d).

To date, only one study has assessed postprandial MPS rates following the ingestion of mixed meals. Subjects consumed a $\sim 1300 \mathrm{kcal}$ lean beef mixed-meal containing either 40 or $70 \mathrm{~g}$ protein [52]. Postprandial MPS rates did not differ between the ingestion of the moderate or the high protein meal at rest or during post-exercise recovery. Interestingly, plasma essential amino acids concentrations were highest at the end of the 4-h postprandial period. This may suggest that large protein-rich mixed meals result in a protein digestion and absorption pattern that reflects a more slowly digestible protein source. Clearly, more research is warranted to assess the MPS response to the ingestion of mixedmeals and its modulation by meal composition. 

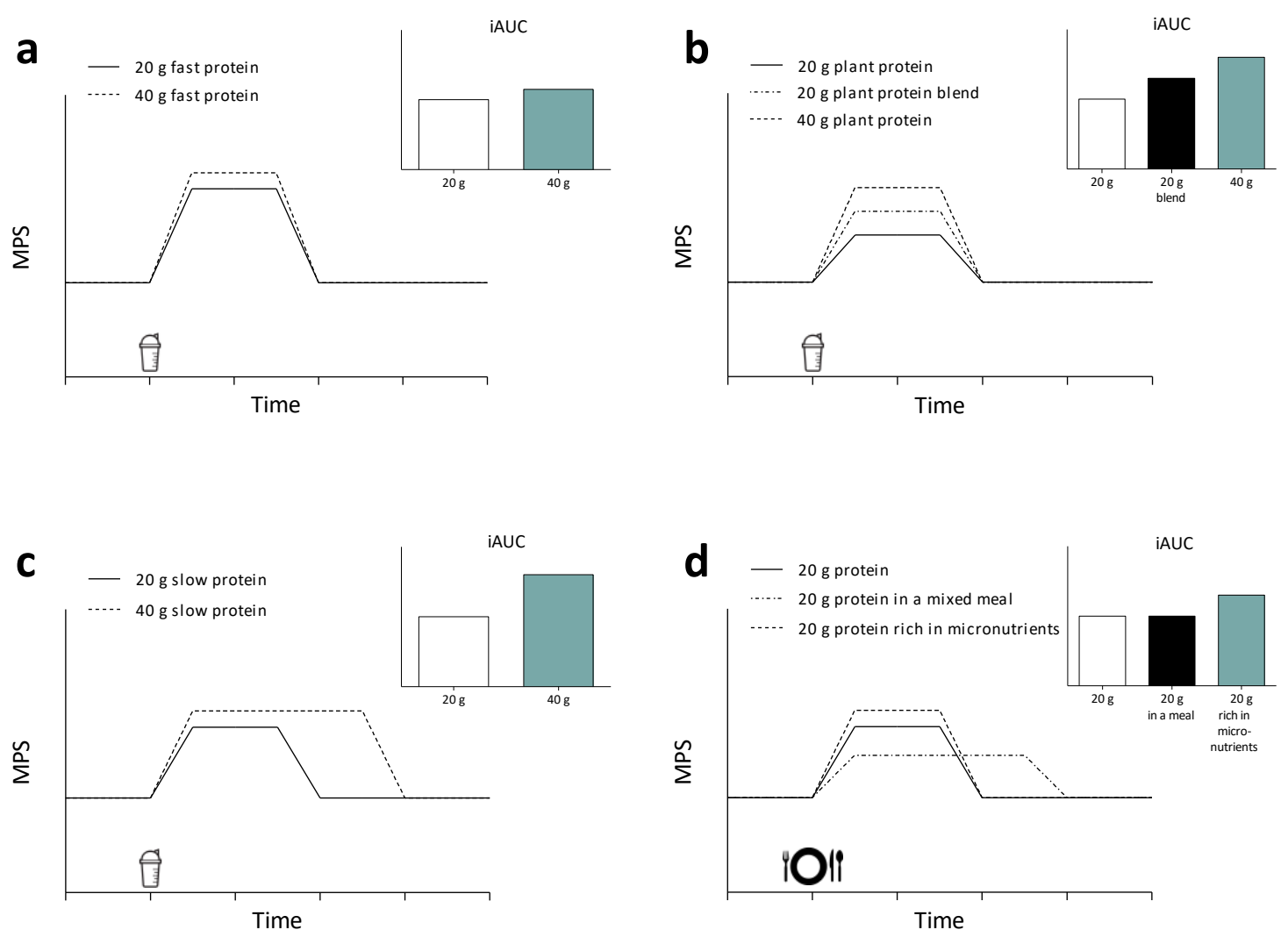

Figure 8.1. Conceptual representation of the muscle protein synthetic response to various feeding protocols. A: The ingestion of $\sim 20 \mathrm{~g}$ rapidly digestible protein results in a near-maximal muscle protein synthetic response. B: The ingestion of a $20 \mathrm{~g}$ plantbased protein typically results in a submaximal muscle protein synthetic response, but the consumption of a greater amount and/or mixing different plant-based protein sources may possibly augment the muscle protein synthetic response. C: The ingestion of $20 \mathrm{~g}$ slowly digestible protein results in a submaximal muscle protein synthetic response, but the ingestion of greater amounts may result in a more prolonged anabolic response. D: Mixed meal ingestion may result in a more moderate, but prolonged, muscle protein synthetic response compared to the ingestion of an isolated whole-food protein source. The micronutrient content of a whole-food protein source may further augment the muscle protein synthetic response. MPS: muscle protein synthesis rate, iAUC: incremental area under the curve.

\section{Alcohol}

Despite warnings from various (inter)national health agencies, alcohol consumption remains culturally engrained worldwide [65]. Interestingly, several studies have reported that athletes are more likely to consume excessive amounts of alcohol, especially as part of binge-drinking practices in team sports $[66,67]$. Parr et al. have demonstrated that alcohol ingestion impairs the MPS response to protein ingestion during post-exercise recovery [68]. A total of $1.5 \mathrm{~g}$ alcohol per $\mathrm{kg}$ bodyweight $(12 \pm 2$ standard drinks) was consumed to reflect alcohol intake levels reported in binge drinking practices of team athletes. These data provide clear proof-of-principle that ingestion of excessive amounts of alcohol can impair post-exercise recovery. Furthermore, Parr et al. observed that alcohol co-ingestion downregulated intramuscular anabolic signalling (i.e. phosphorylation of mammalian target of rapamycin) [68], which is consistent with the majority of data in rodent models [69]. It is unclear how this alcohol-induced attenuation of anabolic signalling is regulated, but direct effects via REDD (regulated in development and DNA damage)-1 and indirect effects via the modulation of the activity of circulating anabolic hormones such as insulin-like growth factor 1 have been proposed [69]. Further work is required to provide more mechanistic insight and to determine whether there is a dose- 
response relationship between alcohol intake and MPS rates and to determine the impact of more moderate alcohol consumption, e.g. drinking 1-2 glasses of wine with dinner.

\section{CONCLUSION}

Combined ingestion of glucose plus fructose can maximize exogenous carbohydrate oxidation rates during exercise and lowers gastrointestinal distress when large amounts of carbohydrates are ingested to maximize post-exercise muscle glycogen repletion rates. The ingestion of $20 \mathrm{~g}$ of high-quality, rapidly digestible protein results in a near-maximal stimulation of MPS rates at rest and during the early stages of recovery after exercise. Ingestion of animal-derived proteins tends to result in a greater increase in MPS rates when compared with plant derived proteins. However, ingestion of larger amounts and/or mixing of different plant-derived proteins may possibly compensate for the lower anabolic properties of individual plant-based proteins. The ingestion of relatively large amounts $(\geq 40$ g) of slowly digestible protein may result in a more prolonged MPS response and may be recommendable when there is a prolonged period until the next feeding opportunity ( $\geq 6 \mathrm{~h}$, e.g. overnight sleep). Recent evidence suggests that whole-food protein sources may contain (micro)nutrients that can modulate the MPS response. In conclusion, nutritional recommendations to maximize the MPS response to feeding depend on both the type of meal and time until the next feeding opportunity, and should be personalized to the individual athlete.

\section{FUTURE RESEARCH}

So far, research on nutritional strategies to augment the adaptive response to exercise have primarily focused on the muscle protein synthetic response to the ingestion of animal-based protein isolates and/or amino acids during relatively short periods of post-exercise recovery. Therefore, future studies should focus on the impact of ingesting alternative protein sources, whole-foods, and mixed meals on post-prandial protein handling and muscle protein synthesis rates. In this regard, some important questions that need to be addressed are:

- What is the impact of the ingestion of various amounts of protein on the duration of the muscle protein synthetic response?

- To what extent does the digestion and absorption rate of a protein modulate its capacity to stimulate overnight muscle protein synthesis rates?

- What is the muscle protein synthetic response to the ingestion of a mixed meal when compared to its protein equivalent as a single food source or protein isolate?

- Which (micro)nutrient(s) can modulate the muscle protein synthetic response to feeding and/or exercise?

- What is the optimal composition of a plant-based protein blend to stimulate muscle protein synthesis rates?

- How do protein requirements to maximize the adaptive response to endurance-type exercise differ from resistance-type exercise? 


\section{REFERENCES}

1. van Loon LJ, Greenhaff PL, Constantin-Teodosiu D, Saris WH, Wagenmakers AJ. The effects of increasing exercise intensity on muscle fuel utilisation in humans. J Physiol. 2001;536:295-304.

2. Cermak NM, van Loon LJC. The use of carbohydrates during exercise as an ergogenic aid. Sports Med. 2013;43:1139-55.

3. Levine SA, Gordon B, Derick CL. Some changes in the chemical constituents of the blood following a marathon race. JAMA. 1924;82:1778-9.

4. Gordon B, Koh LA, Levine SA, Matton M, Scriver WDM, Whiting WB. Sugar content of the blood in runners following a marathon race. JAMA. 1925;85:508-9.

5. Jeukendrup AE, Wagenmakers AJ, Stegen JH, Gijsen AP, Brouns F, Saris WH. Carbohydrate ingestion can completely suppress endogenous glucose production during exercise. Am J Physiol. 1999;276:E672-83.

6. Jeukendrup $A E$, Jeukendrup. Oxidation of Carbohydrate Feedings During Prolonged Exercise. 2012;:1-18.

7. Ferraris RP, Diamond J. Regulation of intestinal sugar transport. Physiol Rev. 1997;77:257-302.

8. Sandle Gl, Lobley RW, Warwick R, Holmes R. Monosaccharide absorption and water secretion during disaccharide perfusion of the human jejunum. Digestion. 1983;26:53-60.

9. Jentjens RLPG, Moseley L, Waring RH, Harding LK, Jeukendrup AE. Oxidation of combined ingestion of glucose and fructose during exercise. J Appl Physiol (1985). 2004;96:1277-84.

10. Wallis GA, Rowlands DS, Shaw C, Jentjens RLPG, Jeukendrup AE. Oxidation of Combined Ingestion of Maltodextrins and Fructose during Exercise. Medicine \& Science in Sports \& Exercise. 2005;37:426-32.

11. Coyle EF, Hagberg JM, Hurley BF, Martin WH, Ehsani AA, Holloszy JO. Carbohydrate feeding during prolonged strenuous exercise can delay fatigue. J Appl Physiol (1985). 1983;55:230-5.

12. Neufer PD, Costill DL, Flynn MG, Kirwan JP, Mitchell JB, Houmard J. Improvements in exercise performance: effects of carbohydrate feedings and diet. J Appl Physiol (1985). 1987;62:983-8.

13. Jeukendrup A, Brouns F, Wagenmakers AJ, Saris WH. Carbohydrate-electrolyte feedings improve $1 \mathrm{~h}$ time trial cycling performance. Int J Sports Med. 1997;18:125-9.

14. Anantaraman R, Carmines AA, Gaesser GA, Weltman A. Effects of carbohydrate supplementation on performance during 1 hour of high-intensity exercise. Int J Sports Med. $1995 ; 16: 461-5$.

15. Carter JM, Jeukendrup AE, Jones DA. The effect of carbohydrate mouth rinse on 1-h cycle time trial performance. Medicine \& Science in Sports \& Exercise. 2004;36:2107-11.

16. Lane SC, Bird SR, Burke LM, Hawley JA. Effect of a carbohydrate mouth rinse on simulated cycling time-trial performance commenced in a fed or fasted state. Appl. Physiol. Nutr. Metab. 2013;38:134-9.

17. Peart DJ. Quantifying the Effect of Carbohydrate Mouth Rinsing on Exercise Performance. J Strength Cond Res. 2017;31:1737-43.

18. Rollo I, Williams C. Effect of mouth-rinsing carbohydrate solutions on endurance performance. Sports Med. 2011;41:449-61.

19. Bergstrom J, Hultman E. A study of the glycogen metabolism during exercise in man. Scand. J. Clin. Lab. Invest. 1967;19:218-28. 
20. Bergstrom J, Hermansen L, Hultman E, Saltin B. Diet, muscle glycogen and physical performance. Acta Physiologica Scandinavica. Blackwell Publishing Ltd; 1967;71:140-50.

21. Hawley JA. Carbohydrate-Loading and Exercise Performance. 2012;:1-9.

22. Casey A, Short AH, Hultman E, Greenhaff PL. Glycogen resynthesis in human muscle fibre types following exercise-induced glycogen depletion. J Physiol. 1995;483 ( Pt 1):265-71.

23. Jentjens $R$, Jeukendrup A. Determinants of post-exercise glycogen synthesis during short-term recovery. Sports Med. 2003;33:117-44.

24. van Loon LJ, Saris WH, Kruijshoop M, Wagenmakers AJ. Maximizing postexercise muscle glycogen synthesis: carbohydrate supplementation and the application of amino acid or protein hydrolysate mixtures. Am J Clin Nutr. 2000;72:106-11.

25. Howarth KR, Moreau NA, Phillips SM, Gibala MJ. Coingestion of protein with carbohydrate during recovery from endurance exercise stimulates skeletal muscle protein synthesis in humans. J Appl Physiol (1985). 2009;106:1394-402.

26. Biolo G, Maggi SP, Williams BD, Tipton KD, Wolfe RR. Increased rates of muscle protein turnover and amino acid transport after resistance exercise in humans. Am J Physiol. 1995;268:E514-20.

27. Phillips SM, Tipton KD, Aarsland A, Wolf SE, Wolfe RR. Mixed muscle protein synthesis and breakdown after resistance exercise in humans. Am J Physiol. 1997;273:E99-107.

28. Tipton KD, Ferrando AA, Phillips SM, Doyle DJ, Wolfe RR. Postexercise net protein synthesis in human muscle from orally administered amino acids. Am J Physiol. 1999;276:E628-34.

29. Burd NA, West DWD, Moore DR, Atherton PJ, Staples AW, Prior T, et al. Enhanced amino acid sensitivity of myofibrillar protein synthesis persists for up to $24 \mathrm{~h}$ after resistance exercise in young men. J Nutr. 2011;141:568-73.

30. Moore DR, Robinson MJ, Fry JL, Tang JE, Glover El, Wilkinson SB, et al. Ingested protein dose response of muscle and albumin protein synthesis after resistance exercise in young men. Am $\mathrm{J}$ Clin Nutr. 2009;89:161-8.

31. Witard OC, Jackman SR, Breen L, Smith K, Selby A, Tipton KD. Myofibrillar muscle protein synthesis rates subsequent to a meal in response to increasing doses of whey protein at rest and after resistance exercise. Am J Clin Nutr. 2013;99:86-95.

32. Tang JE, Moore DR, Kujbida GW, Tarnopolsky MA, Phillips SM. Ingestion of whey hydrolysate, casein, or soy protein isolate: effects on mixed muscle protein synthesis at rest and following resistance exercise in young men. J Appl Physiol (1985). 2009;107:987-92.

33. Wilkinson SB, Tarnopolsky MA, Macdonald MJ, Macdonald JR, Armstrong D, Phillips SM. Consumption of fluid skim milk promotes greater muscle protein accretion after resistance exercise than does consumption of an isonitrogenous and isoenergetic soy-protein beverage. Am J Clin Nutr. 2007;85:1031-40.

34. Levenhagen DK, Gresham JD, Carlson MG, Maron DJ, Borel MJ, Flakoll PJ. Postexercise nutrient intake timing in humans is critical to recovery of leg glucose and protein homeostasis. Am J Physiol Endocrinol Metab. 2001;280:E982-93.

35. Gorissen SHM, Remond D, van Loon LJC. The muscle protein synthetic response to food ingestion. Meat Sci. 2015;109:96-100.

36. Macnaughton LS, Wardle SL, Witard OC, McGlory C, Hamilton DL, Jeromson S, et al. The response of muscle protein synthesis following whole-body resistance exercise is greater following $40 \mathrm{~g}$ than $20 \mathrm{~g}$ of ingested whey protein. Physiol Rep. 2016;4. 
37. van Vliet S, Burd NA, van Loon LJ. The Skeletal Muscle Anabolic Response to Plant- versus Animal-Based Protein Consumption. J Nutr. 2015;145:1981-91.

38. Gorissen SH, Horstman AM, Franssen R, Crombag JJ, Langer H, Bierau J, et al. Ingestion of Wheat Protein Increases In Vivo Muscle Protein Synthesis Rates in Healthy Older Men in a Randomized Trial. J Nutr. 2016;146:1651-9.

39. Reidy PT, Walker DK, Dickinson JM, Gundermann DM, Drummond MJ, Timmerman KL, et al. Protein blend ingestion following resistance exercise promotes human muscle protein synthesis. J Nutr. 2013;143:410-6.

40. Pennings B, Boirie Y, Senden JMG, Gijsen AP, Kuipers H, van Loon LJC. Whey protein stimulates postprandial muscle protein accretion more effectively than do casein and casein hydrolysate in older men. Am J Clin Nutr. 2011;93:997-1005.

41. Burd NA, Yang Y, Moore DR, Tang JE, Tarnopolsky MA, Phillips SM. Greater stimulation of myofibrillar protein synthesis with ingestion of whey protein isolate $\mathrm{v}$. micellar casein at rest and after resistance exercise in elderly men. Br J Nutr. Cambridge University Press; 2012;108:95862.

42. Koopman R, Crombach N, Gijsen AP, Walrand S, Fauquant J, Kies AK, et al. Ingestion of a protein hydrolysate is accompanied by an accelerated in vivo digestion and absorption rate when compared with its intact protein. Am J Clin Nutr. 2009;90:106-15.

43. Wall BT, Hamer HM, de Lange A, Kiskini A, Groen BBL, Senden JMG, et al. Leucine co-ingestion improves post-prandial muscle protein accretion in elderly men. Clin Nutr. 2013;32:412-9.

44. Devries MC, Phillips SM. Supplemental protein in support of muscle mass and health: advantage whey. J Food Sci. 2015;80 Suppl 1:A8-A15.

45. West DWD, Burd NA, Coffey VG, Baker SK, Burke LM, Hawley JA, et al. Rapid aminoacidemia enhances myofibrillar protein synthesis and anabolic intramuscular signaling responses after resistance exercise. Am J Clin Nutr. 2011;94:795-803.

46. Res PT, Groen B, Pennings B, Beelen M, Wallis GA, Gijsen AP, et al. Protein ingestion before sleep improves postexercise overnight recovery. Medicine \& Science in Sports \& Exercise. 2012;44:1560-9.

47. Trommelen J, van Loon LJC. Pre-Sleep Protein Ingestion to Improve the Skeletal Muscle Adaptive Response to Exercise Training. Nutrients. 2016;8.

48. Vliet SV, Beals JW, Martinez IG, Skinner SK, Burd NA. Achieving Optimal Post-Exercise Muscle Protein Remodeling in Physically Active Adults through Whole Food Consumption. Nutrients. $2018 ; 10$.

49. Gorissen SHM, Burd NA, Hamer HM, Gijsen AP, Groen BB, van Loon LJC. Carbohydrate coingestion delays dietary protein digestion and absorption but does not modulate postprandial muscle protein accretion. J Clin Endocrinol Metab. 2014;99:2250-8.

50. Staples AW, Burd NA, West DWD, Currie KD, Atherton PJ, Moore DR, et al. Carbohydrate does not augment exercise-induced protein accretion versus protein alone. Medicine \& Science in Sports \& Exercise. 2011;43:1154-61.

51. Pennings B, Groen BBL, van Dijk J-W, de Lange A, Kiskini A, Kuklinski M, et al. Minced beef is more rapidly digested and absorbed than beef steak, resulting in greater postprandial protein retention in older men. Am J Clin Nutr. 2013;98:121-8.

52. Kim I-Y, Schutzler S, Schrader A, Spencer HJ, Azhar G, Ferrando AA, et al. The anabolic response to a meal containing different amounts of protein is not limited by the maximal stimulation of 
protein synthesis in healthy young adults. Am J Physiol Endocrinol Metab. American Physiological Society; 2015;:ajpendo.00365.2015-33.

53. Greenhaff PL, Karagounis LG, Peirce N, Simpson EJ, Hazell M, Layfield R, et al. Disassociation between the effects of amino acids and insulin on signaling, ubiquitin ligases, and protein turnover in human muscle. Am J Physiol Endocrinol Metab. 2008;295:E595-604.

54. Trommelen J, Groen BBL, Hamer HM, de Groot LCPGM, van Loon LJC. MECHANISMS IN ENDOCRINOLOGY: Exogenous insulin does not increase muscle protein synthesis rate when administered systemically: a systematic review. Eur J Endocrinol. European Society of Endocrinology; 2015;173:R25-34.

55. Elliot TA, Cree MG, Sanford AP, Wolfe RR, Tipton KD. Milk ingestion stimulates net muscle protein synthesis following resistance exercise. Medicine \& Science in Sports \& Exercise. 2006;38:667-74.

56. Gorissen SHM, Burd NA, Kramer IF, van Kranenburg J, Gijsen AP, Rooyackers O, et al. Coingesting milk fat with micellar casein does not affect postprandial protein handling in healthy older men. Clin Nutr. 2015.

57. Edelbroek M, Horowitz M, Maddox A, Bellen J. Gastric emptying and intragastric distribution of oil in the presence of a liquid or a solid meal. J Nucl Med. 1992;33:1283-90.

58. van Vliet S, Shy EL, Abou Sawan S, Beals JW, West DW, Skinner SK, et al. Consumption of whole eggs promotes greater stimulation of postexercise muscle protein synthesis than consumption of isonitrogenous amounts of egg whites in young men. Am J Clin Nutr. 2017;106:1401-12.

59. Stephens FB, Chee C, Wall BT, Murton AJ, Shannon CE, van Loon LJC, et al. Lipid-induced insulin resistance is associated with an impaired skeletal muscle protein synthetic response to amino acid ingestion in healthy young men. Diabetes. 2015;64:1615-20.

60. Hammond KM, Impey SG, Currell K, Mitchell N, Shepherd SO, Jeromson S, et al. Postexercise High-Fat Feeding Suppresses p70S6K1 Activity in Human Skeletal Muscle. Medicine \& Science in Sports \& Exercise. 2016;48:2108-17.

61. Riechman SE, Andrews RD, Maclean DA, Sheather S. Statins and dietary and serum cholesterol are associated with increased lean mass following resistance training. J Gerontol A Biol Sci Med Sci. 2007;62:1164-71.

62. Ziegenfuss TN, Lopez HL, Kedia A, Habowski SM, Sandrock JE, Raub B, et al. Effects of an amylopectin and chromium complex on the anabolic response to a suboptimal dose of whey protein. J Int Soc Sports Nutr. 2017;14:6.

63. Smeuninx B, Nishimura Y, Mckendry J, Limb M, Smith K, Atherton PJ, et al. The effect of acute oral phosphatidic acid ingestion on myofibrillar protein synthesis and intracellular signaling in older males. Clin Nutr. 2018.

64. Bjornsen T, Salvesen S, Berntsen S, Hetlelid KJ, Stea TH, Lohne-Seiler H, et al. Vitamin C and E supplementation blunts increases in total lean body mass in elderly men after strength training. Scandinavian Journal of Medicine \& Science in Sports. 2016;26:755-63.

65. World Health Organization, World Health Organization. Management of Substance Abuse Unit. Global status report on alcohol and health, 2014. World Health Organization; 2014.

66. Burke LM, Read RS. A study of dietary patterns of elite Australian football players. Can J Sport Sci. 1988;13:15-9.

67. Watten RG. Sports, physical exercise and use of alcohol. Scandinavian Journal of Medicine \& Science in Sports. 1995;5:364-8. 
68. Parr EB, Camera DM, Areta JL, Burke LM, Phillips SM, Hawley JA, et al. Alcohol ingestion impairs maximal post-exercise rates of myofibrillar protein synthesis following a single bout of concurrent training. PLoS One. 2014;9:e88384.

69. Steiner JL, Lang $\mathrm{CH}$. Dysregulation of skeletal muscle protein metabolism by alcohol. Am J Physiol Endocrinol Metab. 2015;308:E699-712. 
Summary 
Nutritional intake is an important factor that can modulate exercise performance and recovery. Carbohydrate is the main fuel source during prolonged moderate- to high- intensity exercise. The ergogenic effect of carbohydrate feeding during prolonged moderate- to high-intensity exercise has been well-established. In addition, carbohydrate ingestion represents the most important factor in post-exercise muscle glycogen repletion. Besides the repletion of muscle glycogen stores, skeletal muscle damage repair and reconditioning are important determinants of post-exercise recovery. A single session of exercise stimulates muscle protein synthesis rates. However, the muscle protein net balance will remain negative in the absence of food intake. Protein ingestion stimulates muscle protein synthesis rates, allowing for a positive (post-exercise) muscle protein balance. Multiple factors have been identified that can modulate the post-exercise muscle protein synthetic response to exercise including the amount, type, timing, and distribution of protein ingestion. However, the optimal composition and timing of nutritional intake following exercise remains to be determined. In this thesis, we elaborate on the implications of carbohydrate and protein ingestion as nutritional interventions to improve post-exercise recovery.

Exogenous glucose oxidation rates are restricted to $\sim 1 \mathrm{~g} \cdot \mathrm{min}^{-1}$ even when greater amounts of glucose or glucose polymers are ingested. The rate of exogenous glucose oxidation appears to be limited by the intestinal absorption of glucose. However, fructose co-ingestion can further increase exogenous carbohydrate oxidation rates, which likely can be attributed to distinct intestinal transport routes of glucose and fructose. In chapter 2, we assessed the impact of fructose co-ingestion provided either as a monosaccharide or as part of the disaccharide sucrose on exogenous carbohydrate oxidation rates during prolonged exercise in trained cyclists. We demonstrate that sucrose co-ingestion results in similar exogenous carbohydrate oxidation rates when compared to the combined ingestion of glucose and fructose when total monosaccharide content is matched. These data suggest that sucrose represents an effective carbohydrate source to provide multiple transportable carbohydrates during exercise.

The ergogenic properties of carbohydrate ingestion during prolonged ( $\geq 2 \mathrm{~h}$ ), endurance-type exercise have been well-established. However, carbohydrate ingestion has also been shown to improve performance during high-intensity exercise of a relative short duration ( $\leq 60 \mathrm{~min}$ ), despite that endogenous carbohydrate stores should not be a limiting factor for performance during exercise of such a short duration. This ergogenic effect is now generally attributed to carbohydrate sensing in the oral cavity, as carbohydrate mouth rinsing has been shown to improve exercise capacity and performance during exercise lasting $\sim 60 \mathrm{~min}$. In chapter 3, we assessed the impact of sucrose mouth rinsing on cycling time-trial performance in the fasted and fed state. Sucrose mouth rinsing did not improve time-trial performance in either the fasted or the fed state. Therefore, it remains questionable whether carbohydrate mouth rinsing is truly ergogenic, and if so, under which conditions.

Carbohydrate intake is important for maximizing post-exercise muscle glycogen repletion rates. In chapter 4, we assessed the impact of combining glucose and fructose ingestion on post-exercise muscle glycogen repletion rates. Because of the distinct transport routes of glucose and fructose, we hypothesized that fructose co-ingestion would further increase total carbohydrate absorption rates and, therefore, accelerate muscle glycogen repletion rates. While we did not observe an increase in muscle glycogen repletion rates, fructose co-ingestion resulted in less gastrointestinal distress when 
compared to the ingestion of an isocaloric amount of glucose. Therefore, fructose co-ingestion may facilitate the capacity to achieve optimal carbohydrate intake during recovery from exhaustive exercise.

Whereas carbohydrate intake primarily impacts acute exercise performance and fuel availability, protein ingestion is essential to repair post-exercise muscle damage and optimize the adaptive response to exercise training. Therefore, in chapter 5 , we assessed the daily protein intake and the distribution of protein ingestion in a large cohort of well-trained Dutch athletes. We observed that Dutch athletes habitually consume $>1.2 \mathrm{~g}$ protein $\mathrm{kg}^{-1} \cdot \mathrm{d}^{-1}$, of which slightly more than half $(57 \%)$ coming from animal-based protein sources. However, closer evaluation revealed that protein intake was below the recommend $20 \mathrm{~g}$ per meal for $58 \%$ of the athletes at breakfast and $36 \%$ at lunch. In addition, only $\sim 7 \mathrm{~g}$ protein was consumed as part of an evening snack. These data suggest that daily protein intake distribution and in particular pre-sleep protein ingestion may represent overlooked opportunities for athletes to optimize skeletal muscle reconditioning.

Previous work has shown that dietary protein-derived amino acids are more directed towards activated muscle compared to non-activated muscle during the first few hours of post-exercise recovery. In chapter 6, we assessed whether resistance-type exercise performed in the evening (19:45-20:45 h) increases the overnight muscle protein synthetic response to pre-sleep $(23: 30 \mathrm{~h})$ protein ingestion. We observed that resistance-type exercise performed in the evening augments the overnight muscle protein synthetic response to pre-sleep protein ingestion (i.e., when compared to resting conditions) and allows more of the ingested protein-derived amino acids to be used for de novo muscle protein synthesis during overnight sleep. These findings support the notion that exercise sensitizes muscle tissue to the anabolic properties of protein ingestion beyond the acute, 4-6 $\mathrm{h}$ post-exercise period. Consequently, combining resistance-type exercise with pre-sleep protein ingestion may represent an effective strategy to maximize overnight skeletal muscle reconditioning.

Previous research has shown that pre-sleep ingestion of $40 \mathrm{~g}$ protein increases muscle protein synthesis rates during overnight recovery. In chapter 7, we assessed the impact of ingesting a more moderate $30 \mathrm{~g}$ protein with and without $2 \mathrm{~g}$ additional free leucine prior to sleep on overnight muscle protein synthesis during post-exercise overnight recovery. The ingestion of $30 \mathrm{~g}$ protein improved whole-body protein net balance and provided amino acids that were incorporated into myofibrillar protein during sleep. However, the ingestion of $30 \mathrm{~g}$ protein with or without additional free leucine did not increase overnight post-exercise muscle protein synthesis rates. These data may suggest that a relatively large amount of protein ( $\geq 40 \mathrm{~g}$ ) is required to robustly stimulate muscle protein synthesis over a prolonged period such as overnight sleep.

The overall discussion and implications of the work described in this thesis are provided in chapter 8. We conclude that endurance-type athletes can benefit from the combined ingestion of fructose and glucose to optimize carbohydrate availability during prolonged exercise and post-exercise recovery. Athletes involved in resistance-type exercise should mainly focus on protein ingestion to augment muscle protein anabolism. While athletes habitually consume $>1.2 \mathrm{~g}$ protein $\cdot \mathrm{kg}^{-1} \cdot \mathrm{d}^{-1}$, pre-sleep feeding may represent a practical and efficient strategy to maximize muscle protein synthesis following exercise and, therefore, improve exercise training efficiency. 

Samenvatting 
Inname van de juiste voeding speelt een essentiële rol bij het optimaliseren van sportprestaties en het herstel na inspanning. Koolhydraten zijn de voornaamste brandstof tijdens langdurige inspanning van middelmatige tot hoge intensiteit. Het is alom bekend dat de inname van koolhydraten tijdens dit soort inspanning de prestatie ook daadwerkelijk kan verbeteren. Ook is de inname van koolhydraten vereist voor een zo spoedig mogelijk herstel van de voorraad glycogeen. Daarnaast is het belangrijk dat spierschade wordt hersteld en het spierweefsel zich aanpast aan de inspanning. Zelfs na een eenmalige inspanning of sportactiviteit wordt de aanmaak van spiereiwitten gestimuleerd. Echter zal de balans tussen spiereiwit opbouw en afbraak negatief blijven wanneer er geen voeding wordt genuttigd. De inname van eiwit stimuleert de aanmaak van spiereiwit en zorgt ervoor dat de spiereiwit balans positief kan worden. Dit effect wordt beïnvloed door verschillende factoren zoals de hoeveelheid eiwit, het type eiwit en de timing en verdeling van de eiwitinname. Echter, de optimale samenstelling en het beste moment van voedingsinname na inspanning zijn nog niet geheel duidelijk. Dit proefschrift beschrijft de rol van eiwit en koolhydraten in voedingsinterventies met als doel het herstel na een sportieve inspanning te bevorderen.

De inname van koolhydraten levert extra brandstof op die gebruikt kan worden tijdens intensieve duurinspanning. Echter, er lijkt een maximum te zitten aan de hoeveelheid ingenomen koolhydraten die daadwerkelijk gebruikt kunnen worden als brandstof tijdens inspanning. De opname van koolhydraten in het maagdarmstelsel lijkt hierbij de beperkende factor. De suikers glucose en fructose worden op verschillende manieren opgenomen door het maagdarmstelsel. De combinatie van beide suikers leidt daarom tot een hogere snelheid van koolhydraat opname in vergelijking tot de inname van enkel glucose of fructose. Sucrose (tafelsuiker) bestaat uit één deel glucose en één deel fructose. In hoofdstuk 2 hebben we onderzocht of de toevoeging van fructose of sucrose aan een glucose sportdrank leidt tot een hogere verbrandingssnelheid van de ingenomen koolhydraten. Onze resultaten lieten zien dat de toevoeging van fructose inderdaad de verbrandingssnelheid van de ingenomen koolhydraten verhoogde. Echter was er geen verschil tussen de toevoeging van fructose als los ingrediënt of als onderdeel van sucrose. Deze resultaten suggereren dat simpel tafelsuiker een effectieve koolhydraatbron is om de verbranding van ingenomen koolhydraten te maximaliseren tijdens inspanning.

De hoeveelheid opgeslagen koolhydraten in het lichaam zou ruim voldoende moeten zijn om brandstof te leveren voor intensieve inspanning van ongeveer een uur. Echter zijn er toch onderzoeken die suggereren dat de inname van koolhydraten prestatie bevorderend kan werken tijdens dergelijke inspanning van relatief korte duur. Daarom wordt nu beweerd dat koolhydraten niet enkel dienen als brandstof, maar dat de waarneming van de aanwezigheid van koolhydraten in de mondholte ook al een prestatie bevorderend effect kan hebben. Dit komt voort uit onderzoek dat laat zien dat de mond spoelen met koolhydraten (en vervolgens uitspugen) de prestatie kan verbeteren. In hoofdstuk 3 hebben we het effect van een sucrose mondspoeling bepaald tijdens duurinspanning van ongeveer een uur. Dit hebben we onderzocht in een gevaste toestand en na het nuttigen van een koolhydraatrijk ontbijt. In beide gevallen vonden we geen effect van de sucrose mondspoeling op de prestatie. Het blijft dus de vraag of de mond spoelen met een koolhydraatrijke drank daadwerkelijk de prestatie kan bevorderen, en zo ja, onder welke omstandigheden. 
Zoals eerder besproken leidt de gecombineerde inname van glucose en fructose tot een verhoogde koolhydraatopname en dientengevolge tot een grotere beschikbaarheid van koolhydraten als brandstof tijdens inspanning. Dit concept zou mogelijk ook toegepast kunnen worden om het herstel van de voorraad glycogeen in de spier te versnellen na inspanning. In hoofdstuk 4 hebben we onderzocht of de toevoeging van fructose aan glucose het herstel van spierglycogeen versnelt na inspanning. Echter vonden we geen meerwaarde van de toevoeging van fructose aan glucose op het herstel van de voorraad spierglycogeen. Wel zagen we dat deze combinatie resulteerde in minder maagdarm-klachten bij de sporters. Hierdoor lijkt de gecombineerde inname van glucose en fructose toch een meer praktische samenstelling om te voldoen aan de aanbevolen hoeveelheid koolhydraten na inspanning voor een optimaal herstel.

Terwijl koolhydraten met name brandstof leveren, dienen eiwitten vooral als bouwstof voor spieren. Daarom hebben we in hoofdstuk 5 de dagelijkse eiwitinname van een grote groep goed getrainde Nederlandse atleten in kaart gebracht. We hebben hierbij gekeken naar zowel de totale hoeveelheid als de verdeling van de eiwitinname. We zagen dat de meeste sporters meer dan genoeg eiwit binnen kregen om aan de dagelijks aanbevolen hoeveelheid te voldoen. Echter was deze inname niet goed verdeeld over de dag. Er zit bijvoorbeeld een zeer lange periode zonder eiwitinname tussen het avondeten en het ontbijt de volgende dag. De inname van eiwitten voor het slapen gaan zou dus mogelijk een punt van verbetering kunnen zijn voor goedgetrainde sporters.

De inname van eiwitten levert bouwstenen voor het herstel en de groei van spieren. Krachttraining zorgt ervoor dat meer van deze bouwstenen in de spier terecht komen. In hoofdstuk 6 hebben we gekeken of een dergelijk effect ook tijdens de slaap aanwezig is. Onze resultaten toonden aan dat de inname van eiwitten voor het slapen gaan inderdaad bouwstenen voor spierherstel levert tijdens de nacht. Zoals verwacht, werd dit proces versterkt door een sessie krachttraining eerder in de avond. Deze bevindingen ondersteunen het idee dat de combinatie van krachtinspanning en eiwitinname voor het slapen gaan ook's nachts de aanmaak van spiereiwit kan bevorderen.

Eerder onderzoek heeft aangetoond dat de inname van $40 \mathrm{~g}$ eiwit voor het slapen gaan de aanmaak van spiereiwit tijdens de nacht kan stimuleren. In hoofdstuk 7 hebben we onderzocht of de inname van een kleinere, meer praktische hoeveelheid van $30 \mathrm{~g}$ eiwit ook de aanmaak van spiereiwit tijdens de nacht kan vergroten. Hoewel de inname van $30 \mathrm{~g}$ eiwit voor het slapen gaan de totale aanmaak van eiwitten in het lichaam verbeterde, was dit effect niet voldoende zichtbaar in de spier. Dit suggereert dat de inname van een relatieve grote hoeveelheid eiwit (40 $\mathrm{g}$ of meer) nodig is om een duidelijk effect te zien op aanmaak van spiereiwit tijdens de nacht.

De algehele discussie en praktische toepassing van de resultaten uit de studies in dit proefschrift worden beschreven in hoofdstuk 8 . We concluderen dat duuratleten voordeel kunnen halen uit een gecombineerde inname van glucose en fructose om de koolhydraatbeschikbaarheid te vergroten tijdens inspanning of tijdens het herstel na inspanning. Atleten die gefocust zijn op krachtsport moeten zich meer richten op de inname van eiwitten. Hoewel sporters in het algemeen meer dan 1,2 g eiwit per kg lichaamsgewicht per dag eten, blijkt de inname van extra eiwit voor het slapen gaan een goede mogelijkheid voor veel atleten om spierherstel en spieradaptatie verder te verbeteren. 

Valorization 


\section{Relevance}

The popularity of sports goes back to the first Olympic games $765 \mathrm{BC}$. More recently, it is estimated that the 2019 Super Bowl was watched by 98.2 million people [1]. But engagement in exercise and sports activities is also rising, with participation in the United states rising from 15\% in 2000 to $23 \%$ in 2016 [2]. Consistent with this growth, sports nutrition sales in the United States are increasing, with protein powder products having the largest market share with a total sales worth of $\$ 7.7$ billion in 2016 [3]. Clearly, there is a high consumer interest in sports nutrition products.

\section{Innovative applications}

Sports nutrition research is of great value to both consumers and food producers. It allows consumers to make more informed decisions on sport nutrition product use and allows producers to make evidence-based products and claims. Research opens up the possibility to optimize current nutritional protocols and identify novel applications. For example, our lab has recently identified pre-sleep protein ingestion as a novel dietary strategy to augment the adaptive response to exercise training. However, in chapter 5, we have identified that pre-sleep protein ingestion is currently underused by athletes as an opportunity to consume a high protein meal. In addition, the combination of our earlier work [1] together with the research described in chapter 7, suggests that greater amounts of protein may need to be consumed prior to sleep compared to the $\sim 20 \mathrm{~g}$ protein that is recommended for meals and/or as post-workout snack. This work opens up the opportunity for the food industry to make more tailored products for specific meal moments, by taking into account factors such as amount, type, matrix, and processing of the protein product. Moreover, the application of pre-sleep protein may extend beyond the athletic population. For example, we have recently observed that pre-sleep protein feeding can also improve overnight muscle anabolism in healthy older subjects [2]. This is an important finding, as it may represent a novel nutritional strategy to combat age-related muscle loss (sarcopenia), and begs the question if patients in more clinically compromised conditions characterized by accelerated muscle loss such as acute sickness, systemic inflammation, and muscle disuse, may also benefit from pre-sleep protein ingestion.

Another example of innovation is the application of sugar(s) in sports nutrition. Whereas the advice to the general public is to have a moderate sugar intake, this does not necessarily apply to athletes. For example, the intake of carbohydrate-rich sports drinks can help athletes to maintain energy balance during extreme exercise conditions such as the Tour the France [3]. In fact, much research is now focusing on the amount and composition of sports nutrition drinks to maximize carbohydrate availability during and following exercise. In chapters 2 and 4, we have demonstrated that sucrose feeding is an effective strategy to maximize carbohydrate availability during exercise and help restore muscle energy stores after exercise. This discrepancy between carbohydrate recommendations for athletes and the general public highlights the need for personalized nutritional advice and sports specific products.

Basic sports nutrition research usually entails the study of certain nutritional concepts in a young, healthy, very homogenous population. Yet, the findings can provide very relevant information for a range of different applications: 1) elite sports, since most invasive or long-term work is not done in actual elite athletes, 2) general recreational sports for 'health maintenance and/or improving physical performance for the individual, 3) ageing, see the previously described translation of the application 
of pre-sleep protein from the athletic to the older population, and 4) clinical populations, in which only limited research is possible and ideally not performed unless there's substantial indication the interventions are safe and of potential benefit.

\section{Knowledge dissemination}

The findings from the research in this thesis have already been disseminated in different ways to educate and advice. Of course, the findings have been presented in scientific publications and at scientific conferences. In addition, the knowledge has been incorporated in several educational programs offered at Maastricht University, a course on Fontys and HAN University of Applied Sciences, a Belgium sport Dietetics course and a course on sports nutrition for sports physicians. Furthermore, an exciting aspect of sports nutritional research is the large interest of the public. For example, my Instagram account that exclusively shares evidence-based nutrition and exercise content currently has over 18.000 followers. I frequently get invited on podcasts to discuss my research. For example, two interviews on the Youtube channel Jeff Nippard together got over 276.000 views. These novel ways of knowledge dissemination and communicating with the public allow researchers to influence the public interpretation of their research. This has advantages for everyone involved:

- researchers: as the academic field is quite demanding, it can be very rewarding to see so much interest in your work.

- public: get information straight from the "horse's mouth", instead of the sometimesmisleading headlines and conclusions written by the media.

- funding partners: it shows that the funded work has clear interest from the general public

The research in this thesis has also been partly funded by industry partners. This highlights the interest of the food industry in sports nutrition research. Several of the nutritional strategies investigated in this thesis may lead to the development of specific products. For example, the high carbohydrate intakes investigated during and after exercise would not be feasible with whole-food items and require specifically designed sports nutrition products. Likewise, the ingestion of pre-sleep protein may be more practical in the form of a specific product that is ready to consume and in a concentrated form such as a protein bar or drink.

\section{Personal perspective}

An argument can be made that it's the obligation of a researcher to provide a well-balanced and correct knowledge transfer. While there is more information available for the public than ever, this coincides with more discussion on what the right information is and the rapid rise and use of the term 'fake news'. There is clearly a need from the public to have access to true experts that communicate with the public in more lay-terms. There is also increasing awareness among researchers that communication to the public is necessary to combat misinformation [4]. But the high current workload and competitive nature of academia make it unlikely that many researchers will allocate time for such matters if they do not believe it is recognized as "career capital". However, the use of social media is correlated with greater citation scores [5]. This may suggest that at least some social media use might be worthwhile. Furthermore, journals appear to increasingly value social media metrics and start displaying such metrics for each paper. I would not be surprised if such metrics may become even more relevant in the future, similar to traditional metrics such as the impact factor of a journal and a citation score of a paper. Journal editors may take the metrics of authors into account when 
considering a paper as candidate for publication. Therefore, I expect knowledge dissemination (e.g. via a social media presence) will become the norm in the future.

\section{Concluding remarks}

The studies described in this thesis have allowed for a further optimization of carbohydrate and protein supplementation strategies to improve exercise recovery. In addition, the observed suboptimal protein distribution in well-trained Dutch athletes indicates there is still room for improvement in translating research to practice. 


\section{REFERENCES}

1. Statistica, TV viewership of the Super Bowl in the United States from 1990 to 2019, Statistica, https://www.statista.com/statistics/216526/. Accessed: 30-07-2019.

2. Statistica, Participation in leisure-time aerobic and muscle strengthening activities in the U.S. from 1999 to 2016, https://www.statista.com/statistics/186911/. Accessed: 30-07-2019.

3. Statistica, Global consumer sport nutrition sales in 2014, 2016, 2018, and 2020, by product type, https://www.statista.com/statistics/748273/. Accessed: 30-07-2019.

4. Res PT, Groen B, Pennings B, Beelen M, Wallis GA, Gijsen AP, et al. Protein ingestion before sleep improves postexercise overnight recovery. Medicine \& Science in Sports \& Exercise. 2012;44:1560-9.

5. Kouw IW, Holwerda AM, Trommelen J, Kramer IF, Bastiaanse J, Halson SL, et al. Protein Ingestion before Sleep Increases Overnight Muscle Protein Synthesis Rates in Healthy Older Men: A Randomized Controlled Trial. J Nutr. 2017;147:2252-61.

6. Brouns F, Saris WH, Stroecken J, Beckers E, Thijssen R, Rehrer NJ, et al. Eating, drinking, and cycling. A controlled Tour de France simulation study, Part II. Effect of diet manipulation. Int J Sports Med. 1989;10 Suppl 1:S41-8.

7. Burke LM. Communicating Sports Science in the Age of the Twittersphere. Int J Sport Nutr Exerc Metab. 2017;27:1-5.

8. Lamb CT, Gilbert SL, Ford AT. Tweet success? Scientific communication correlates with increased citations in Ecology and Conservation. PeerJ. 2018;6:e4564. 



\section{Dankwoord}


Promoveren kun je simpelweg niet alleen doen. Dit proefschrift is mogelijk gemaakt door de directe en indirecte bijdrage van velen. Daarom wil ik graag een aantal mensen in het bijzonder bedanken.

Luc, wat heb jij hebt een fantastische omgeving gecreëerd voor promotiestudenten. Een promotie bij het M3-lab betekent zoveel mogelijkheden, expertise, en ondersteuning van collega's, zodat je je een kind in een snoepwinkel waant. Inhoudelijk heb ik enorm veel van je geleerd en ik kon lekker mezelf zijn bij jou. Ik ben blij dat we onze samenwerking de komende jaren nog kunnen voortzetten!

"Even een kort vraagje". Lex, jouw deur staat altijd open. Helaas zit je wel met de rug naar de deuropening, dus je moet wel eerst even iets zeggen om je aandacht te trekken (kloppen kennen we niet in Brabant). Jij was de rots in de branding waar ik kon binnenstappen als er "gedoe" was waar ik geen tijd en geduld voor had om uit te zoeken (en ik vind dingen nogal snel een gedoe...).

Naomi, we hebben helaas niet heel veel kunnen samenwerken. Toch bedankt voor je vertrouwen in mij tijdens het sollicitatieproces en ik hoop dat dit proefschrift je trots maakt.

I would like to thank the members of the Assessment Committee and the carona:

Prof. dr. E.E Blaak, Emeritus Prof. dr. W.H.M Saris, Emeritus Prof. dr. M.A. van Baak, Prof. dr. ir. C.P.G.M de Groot, and Prof. dr. S.M. Phillips. Thank you for agreeing to thoroughly review my thesis and being part of my defense ceremony.

Ik kan mijn huidige en voorgaande collega's niet genoeg bedanken. Bart, mijn stage bij jou was me zo goed bevallen dat ik vervolgens zelf het onderzoek in wilde. Zowel de studies in dit proefschrift als meer recente studies bevatten vaak biopten op de meest onpraktische tijden. Ik kon echter altijd op Tim, Fleur, Joey, Floris, en Lisanne rekenen als biopteurs. Andy en Imre, bedankt voor de nachtelijke entertainment en ondersteuning. Annemie, Antoine, Freek, Janneau, Joan, Joy, Hasibe, en Wendy, enorm bedankt voor al jullie werk: van testdrank bereiding tot ingewikkelde tracer-analyses op het SIRC. Joy, de cafeïne in jouw exotische smaakjes monster was essentieel voor het schrijven van dit proefschrift.

Jean, Cas, en Andy, volgens mij zijn we het er nog steeds niet over eens waar B3-united voor staat, maar onze B3-united groepsfoto hangt nog steeds boven de deur van mijn kantoor. Speaking of kantoor, Jean, wat hebben wij samen veel uren doorgebracht samen (gelukkig niet allemaal op kantoor)! Als iemand me veel geholpen heeft dan ben jij het wel. Cas, wanneer jij hielp op een testdag dan wist je dat het entertainment package er bij inbegrepen was. Andy en Evelien, bedankt dat we bij jullie thuis welkom waren voor een gezellige avond. Kevin en Maarten, later sloten jullie je hier ook bij aan en werd het nog gezelliger ("hardest choice of my life....Overbloke!"). Maarten, bedankt dat je om al mijn grappen lachte. Nou ik er over nadenk, lachte je ook als ik serieus was. Kevin, ik leerde jou kennen in de gym, dus dat was al een goed begin. Al snel kwam je helpen bij studies (met 2 min pauzes om op de gang een litertje full-fat chocomel weg te tikken).

Desiree, Cleo en Claudia, jullie ontvingen me altijd met open armen wanneer ik bij jullie binnenliep, ook al betekende dat vaak papierwerk. Harry, Marc, Paul en Loek, als iets wel op mijn zenuwen werkt dan is het technische problemen, dus zonder jullie had ik mijn computer allang doorgebroken (nu doet 
slechts $10 \%$ aan de rechterkant van het scherm het niet. Stefan, bedankt dat je me op sleeptouw nam in Canada. Milan, het samen werken aan Nutrition Tactics geeft me altijd enorm veel energie! Philippe, wat ben jij een teamspeler! Wanneer je bij jou binnenstapte met een vraag, dan wist je gewoon dat jij echt je uiterste best zou doen om iemand zo goed en zo veel mogelijk te helpen, hoeveel je zelf ook op je bordje had liggen. Wesley, helaas kon je niet met de overnacht studie helpen tijdens je stage, maar even better: je hebt uiteindelijk meegedaan als proefpersoon! Michelle, dankzij jou wist ik eindelijk wie Ed Sheeran was. Daarnaast heeft iedereen in het lab me regelmatig geholpen met een handje assistentie tijdens een testdag, uitleg, voorbereiding op een presentatie, en gezelligheid. Dus super bedankt Henrike, Imre, Marlou, Cindy, Ben, Tyler, Nick, Astrid, Henrike, Milou, Kristen, Rachel, en Jan-Willem.

Mathijs, Tanja, Emanuel, Guy, Kelly en Inez, bedankt voor de praatjes op de gang!

To Prof. dr. Martin Gibala and Prof. dr. S.M. Phillips, thank you for allowing me over at McMaster university and collaborating on a project. Martin and Josh, thank you for running the project with me, lending me your bike, and showing me the best Burgers in Ontario.

Ik wil alle proefpersonen die meegewerkt hebben aan de onderzoeken in dit proefschrift hartelijk bedanken. Zonder proefpersonen is er simpelweg geen onderzoek. Extra bedankt aan veteranen proefpersonen the Cage, Thijs of the Stars, en Serge. Ook wil ik alle stagiaires bedanken voor hun inzet.

Homebizzles, wat zijn jullie een fantastische groep mensen! Jullie hebben me zoveel leuke herinneringen gegeven, en ik twijfel er niet aan dat dat er nog meer gaan worden. Maar naast afleiding hebben jullie me ook altijd aangemoedigd!

Paranymfen Jean en Milan, bedankt voor alle hulp bij het afronden van dit proefschrift en het regelen van het promotiefeest. Verspil dit nou niet met een gekke presentatie op de dag zelf!

Ma en pa, bedankt dat jullie me de kans hebben gegeven om te gaan studeren en alles wat jullie voor me doen. Ik kom nog steeds regelmatig met veel plezier een weekendje naar huis. Mam, het traantje over jouw wang toen ik mijn MSc diploma kreeg is nog steeds een van de mooiste momenten uit mijn leven.

Sarah, je t'aime. Thank you for your support, love, and being my allesje. 



\section{Curriculum Vitae}




\section{LIST OF PUBLICATIONS}

1. Trommelen J, Holwerda AM, Nyakayiru J, Gorissen SH, Rooyackers O, Burd NA, Boirie Y, van Loon LJC. The intrinsically labeled protein approach is the preferred method to quantify the release of dietary protein derived amino acids into the circulation. Am J Physiol Endocrinol Metab. 2019 Sep 1;317(3):E433-E434.

2. Snijders T, Trommelen J, Kouw IWK, Holwerda AM, Verdijk LB, van Loon LJC. The Impact of Pre-sleep Protein Ingestion on the Skeletal Muscle Adaptive Response to Exercise in Humans: An Update. Front Nutr. 2019 Mar 6;6:17.

3. Nyakayiru J, Fuchs CJ, Trommelen J, Smeets JSJ, Senden JM, Gijsen AP, Zorenc AH, van Loon LJC, Verdijk LB. Blood Flow Restriction Only Increases Myofibrillar Protein Synthesis with Exercise. Med Sci Sports Exerc. 2019 Jan 25.

4. Trommelen J, Betz MW, van Loon LJC. The Muscle Protein Synthetic Response to Meal Ingestion Following Resistance-Type Exercise. Sports Med. 2019 Feb;49(2):185-197.

5. Haskovic M, Derks B, van der Ploeg L, Trommelen J, Nyakayiru J, van Loon LJC, Mackinnon S, Yue WW, Peake RWA, Zha L, Demirbas D, Qi W, Huang X, Berry GT, Achten J, Bierau J, RubioGozalbo ME, Coelho Al. Arginine does not rescue p.Q188R mutation deleterious effect in classic galactosemia. Orphanet J Rare Dis. 2018 Nov 26;13(1):212.

6. Kouw IW, Holwerda AM, Trommelen J, Kramer IF, Bastiaanse J, Halson SL, Wodzig WK, Verdijk LB, van Loon LJ. Protein ingestion before sleep increases overnight muscle protein synthesis rates in healthy older men: a randomized controlled trial. J Nutr. 2017 Dec;147(12):2252-2261

7. Trommelen J, Kouw IWK, Holwerda AM, Snijders T, Halson SL, Rollo I, Verdijk LB, van Loon LJC. Pre-sleep dietary protein-derived amino acids are incorporated in myofibrillar protein during post-exercise overnight recovery. Am J Physiol Endocrinol Metab. 2017 May 2018 May 1;314(5):E457-E467

8. Nyakayiru J, Jonvik KL, Trommelen J, Pinckaers PJ, Senden JM, van Loon LJ, Verdijk LB, Beetroot Juice Supplementation Improves High-Intensity Intermittent Type Exercise Performance in Trained Soccer Players, Nutrients, 2017 Mar 22;9(3).

9. Trommelen J, Fuchs CJ, Beelen M, Lenaerts K, Jeukendrup AE, Cermak NM, van Loon LJ, Fructose and Sucrose Intake Increase Exogenous Carbohydrate Oxidation during Exercise, Nutrients. 2017 Feb 20;9(2).

10. Trommelen J, van Loon LJ. Pre-Sleep Protein Ingestion to Improve the Skeletal Muscle Adaptive Response to Exercise Training. Nutrients. 2016 Nov 28;8(12).

11. Gillen JB, Trommelen J, Wardenaar FC, Brinkmans NY, Versteegen JJ, Jonvik KL, Kapp C, de Vries J, van den Borne JJ, Gibala MJ, van Loon LJ. Dietary Protein Intake and Distribution Patterns of Well-Trained Dutch Athletes. Int J Sport Nutr Exerc Metab. 2017 Apr;27(2):105-

12. Trommelen J, Holwerda AM, Kouw IW, Langer H, Halson SL, Rollo I, Verdijk LB, VAN Loon LJ. Resistance Exercise Augments Postprandial Overnight Muscle Protein Synthesis Rates. Med Sci Sports Exerc. 2016 Dec;48(12):2517-2525.

13. Holwerda AM, Kouw IW, Trommelen J, Halson SL, Wodzig WK, Verdijk LB, van Loon LJ. Physical Activity Performed in the Evening Increases the Overnight Muscle Protein Synthetic Response to Presleep Protein Ingestion in Older Men., J Nutr. 2016 Jul;146(7):1307-14 
14. Trommelen J, Beelen M, Pinckaers PJ, Senden, JM, Cermak NM, van Loon LJ. Fructose Coingestion Does Not Accelerate Postexercise Muscle Glycogen Repletion, Med Sci Sports Exerc. 2016 May;48(5):907-12

15. Trommelen J, Beelen M, Mullers M, Gibala MJ, van Loon LJ, Cermak NM. A Sucrose Mouth Rinse Does Not Improve 1-hr Cycle Time Trial Performance When Performed in the Fasted or Fed State.Int J Sport Nutr Metab. 2015 Dec;25(6):576-83.

16. Trommelen J, Groen BB, Hamer HM, de Groot LC, van Loon LJ. MECHANISMS IN ENDOCRINOLOGY: Exogenous insulin does not increase muscle protein synthesis rate when administered systemically: a systematic review, Eur J Endocrinol. 2015 Jul;173(1):R25-3

17. Holwerda AM, van Vliet $\mathrm{S}$, Trommelen J, Refining dietary protein recommendations for the athlete, J Physiol. 2013 Jun 15;591 (Pt 12): 2967-9 


\section{ORAL PRESENTATIONS}

- Eiwit \& Spiermassa, Invited Lecture, "Eiwitinname ter bevordering van spiermassa in sporters", Maart, 2019, Utrecht, the Netherlands

- Food Valley Summit Sports \& Nutrition, Invited Lecture, "Overnight de novo muscle protein synthesis, October 2018", Ede, the Netherlands

- Spazio Nutrizione, Invited Lecture, "Pre-sleep protein and muscle hypertrophy", March 2018, Milan, Italy.

- Sport \& Voeding Congress, Invited Lecture, "Voeding en Beweging voor Spieropbouw" October 2017, Papendal te Arhnem, the Netherlands

- American College of Sports Medicine, Invited Lecture, "Pre-sleep nutrition: to eat or not to eat?" June 2017, Denver, USA

- Associação Portuguesa de Nutrição Entérica e Parentérica, Invited Lecture, "Protein ingestion before sleep and Muscle Mass" and "The role of fructose and sucrose in sports nutrition", March 2017, Porto, Portugal

- Joint European Stable Isotopes User group Meeting, Oral presentation, "Carbohydrate ingestion during prolonged endurance-type exercise", September 2016, Ghent, Belgium

- European College of Sport Science, Oral presentation, "Protein ingestion before sleep provides precursors for post-exercise de novo muscle protein accretion", July 2016, Vienna, Austria

- American College of Sports Medicine, Thematic poster presentation, "Protein ingestion before sleep provides precursors for post-exercise de novo muscle protein accretion", June 2016, Boston, USA

- European College of Sport Science, Mini-oral presentation, "Combined ingestion of glucose and fructose for post-exercise muscle glycogen repletion", June 2015, Malmö, Sweden

- European College of Sport Science, Mini-oral presentation, "Carbohydrate mouth rinsing does not improve time trial performance in the fasted or fed state" June 2013, Barcelona, Spain 


\section{POSTER PRESENTATIONS}

- American College of Sports Medicine, Thematic poster presentation, "Fructose and Sucrose Intake Increase Exogenous Carbohydrate Oxidation during Exercise" June 2017, Denver, USA

\section{HONOURS AND AWARDS}

- Applied Science Poster Prize, School of Nutrition and Translational Research in Metabolism, 2016

- GSSI Nutrition Award Finalist $4^{\text {th }}$ place, European College of Sport Science, 2016

- GSSI Sport Nutrition Award, American College of Sports Medicine, 2016

- Gail E. Butterfield Nutrition Travel Award, American College of Sports Medicine, 2016

- Naomi Cermak Scholarship Recipient Award, 2016

- Young Investigator Award 4th place, European College of Sport Science, 2015

- MSc graduated top honours, Wageningen University, 2012

\section{CONTRIBUTION TO BOOKS}

- van Loon LJ, Trommelen J, van Erp-Baart AM, and Saris WH. Voeding bij intensieve sportbeoefening. In: Voeding en diëtetiek. Houten, Bohn Stafleu van Loghum, 2018. 


\section{ABOUT THE AUTHOR}

Jorn Trommelen was born on Februari 8, 1987 in Goirle, The Netherlands. He completed secondary school at the Mill Hill college in Goirle in 2005. Jorn obtained his master degree in Nutrition \& Health in 2012 with top honours.

In 2012, Jorn started his PhD at the department of Human Biology at Maastricht University within NUTRIM School of Nutrition and Translational Research in Metabolism under de supervision of prof. Luc van Loon and dr. Lex Verdijk. Jorn conducted research within Food and Nutrition project titled "Muscle health and performance", that focused on pre-sleep protein ingestion as a novel strategy to promote overnight protein accretion. In addition, he completed a project entitled "Sucrose as a preferred carbohydrate source in sports nutrition" that was partly funded by Kenniscentrum suiker \& voeding.

During his PhD, Jorn was awarded with an European College of Sports Science (ECSS) mini-oral Young Investigator Award (2015), a School of Nutrition and Translational Research in Metabolism (NUTRIM) Applied Science Poster Award (2016), a Gail E. Butterfield Nutrition Travel Award and the Gatorade Sport Science Institute (GSSI) Sports Nutrition award at the American College of Sports Medicine (2016), and a Gatorade Sport Science (GSSI) Nutrition award at the European College of Sports Science (2016). In addition, he was awarded the Naomi Cermak Scholarship (2016), which allowed him to travel to McMaster University, Hamilton, Canada to collaborate on an interventional high-intensity interval exercise training study in collaboration with prof. Stuart Phillips and prof. Martin Gibala.

After defending his thesis, Jorn will continue to work at Maastricht University as an Assistant Professor. 
Financial Support 
Financial support for printing of this thesis was kindly provided by:
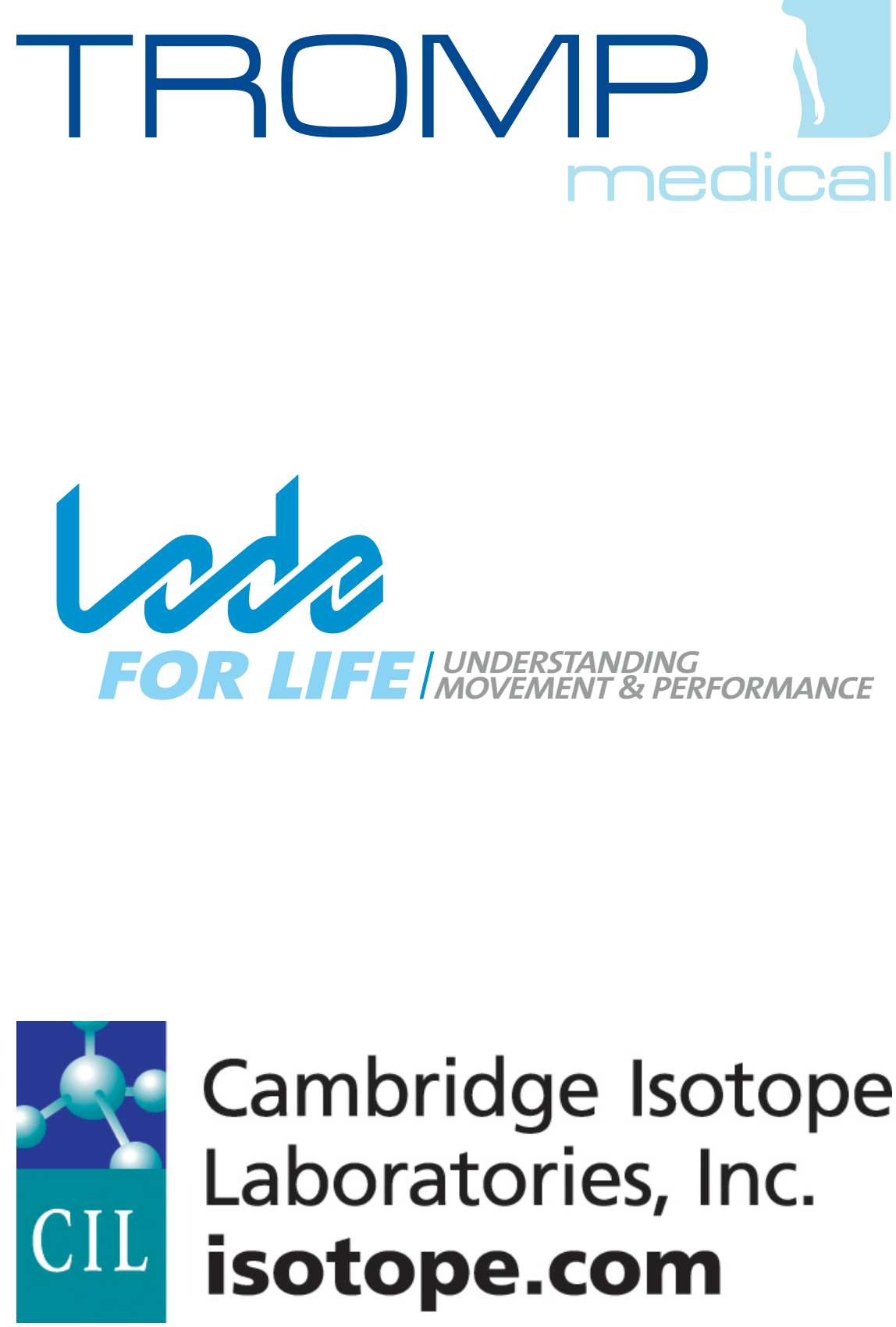

\section{Cambridge Isotope Laboratories, Inc. isotope.com}

